UNIVERSIDADE DE SÃO PAULO

FACULDADE DE FILOSOFIA, LETRAS E CIÊNCIAS HUMANAS

DEPARTAMENTO DE FILOSOFIA

ANDRÉS ALFREDO RODRÍGUEZ IBARRA

Uma relação sempre atual: a liberdade recalcitrante de Michel Foucault.

São Paulo

2007 
ANDRÉS ALFREDO RODRÍGUEZ IBARRA

\title{
Uma relação sempre atual: a liberdade recalcitrante de Michel Foucault.
}

\author{
Tese apresentada à Banca Examinadora da \\ Pós-Graduação em Filosofia da Faculdade \\ de Filosofia, Letras e Ciências Humanas da \\ Universidade de São Paulo para obtenção \\ do título de Doutor em Filosofia. \\ Área de Concentração: Ética e Filosofia \\ Política. \\ Orientador: Prof. Dr. Milton Meira do \\ Nascimento
}

São Paulo 
Andrés Alfredo Rodríguez Ibarra

Uma relação sempre atual: a liberdade recalcitrante de Michel Foucault

Tese apresentada à Banca Examinadora da Pós-Graduação em Filosofia da Faculdade de Filosofia, Letras e Ciências Humanas da Universidade de São Paulo para obtenção do título de Doutor em Filosofia.

Área de Concentração: Ética e Filosofia Política

Aprovado em:

\section{Banca Examinadora}

Prof. Dr.

Instituição: Assinatura:

Prof. Dr.

Instituição: Assinatura:

Prof. Dr.

Instituição: Assinatura:

Prof. Dr.

Instituição: Assinatura:

Prof. Dr.

Instituição: Assinatura: 
Dedico este trabalho a minha mãe (em memória), Patrícia Ibarra Corrales, que não se encolheu diante dos desafios que se apresentam aos que deixam, por quaisquer motivos que seja, sua terra natal - o Chile, no caso. Pelo contrário, filha de alquimista que era-e escultora ela própria—, soube aqui inventar formas de exercer sua paixão pela descoberta e pela vida, marcas que deixou impressas em muitos daqueles que a conheceram. 


\section{AGRADECIMENTOS}

Gostaria de agradecer ao prof. Milton Meira do Nascimento, meu orientador, que se dispôs a patrocinar esta tese num momento em que ela já estava bem avançada, em plena fase de escrita, numa demonstração de desprendimento pessoal e de responsabilidade institucional, pois, por esse gesto, permitiu que o trabalho até então realizado permanecesse e fosse terminado no lugar onde foi gestado: a Faculdade de Filosofia, Letras e Ciências Humanas da Universidade de São Paulo. Esta, que pude perceber, no pouco tempo que tive para nela transitar, como uma verdadeira usina de idéias, também é, como até certo ponto é natural, um chamariz e uma plataforma para os mais diversos tipos de exercício da vaidade; e um dos méritos do prof. Milton, creio, é o de perceber que há e pode haver outros jogos além desse, mais importantes e mais interessantes, além de alimentos, para a alma, mais nutritivos e saborosos.

Ari Tank Brito, amigo e colega da pós em filosofia, foi fundamental pela sua postura amiga nos momentos de maior dificuldade e pela sua decidida e decisiva defesa dos meus interesses junto ao departamento, dada a minha distância e desconhecimento das pessoas e regras do jogo. Se alguma expectativa eu tinha, no começo desta jornada, em relação a esta empreitada paulistana, de encontrar "gente de verdade", ela foi plenamente satisfeita na sua figura parresiasta, crítica, hedonista e profundamente humana.

Agradeço aos colegas da pós Maria Luiza, Patrícia, Evangelina, Gabriela, Edson, Roberto e Alfredo, pela rica troca de idéias, informações e experiências. 
À professora Marta Rosa Amoroso e aos colegas pós-graduandos que participaram do seu curso "Corpo, Pessoa e Substância-leituras de etnologia indígena", no âmbito do departamento de Antropologia Social da FFLCH, no $2^{\circ}$ semestre de 2004, que foi uma oportunidade feliz de intercâmbio de horizontes de pesquisa, cujos resultados aparecem na última seção desta tese.

Aos colegas da CPEO, da Câmara Legislativa do DF, em especial a Antônio Noleto, que durante as longas tardes na sala B15, se adiantava em assegurar aos poucos que nela entravam, que o uso que eu então fazia da luminária que tinha trazido de casa—naquele ambiente amplamente iluminado por janelões—era mesmo necessário, pelo grande volume de leitura que eu tinha a realizar. Também gostaria de agradecer a preocupação de outros colegas e amigos da CLDF: Bia, Maristela, Dalva, João Patrão, Parucker e Kleber e, muito especialmente, Carmen, que se dispôs a ler o primeiro capítulo escrito, disse que não entendeu nada, mas eu sei (ou espero) que foi (tenha sido) por pura modéstia e pelo seu jeito brincalhão. Valdenora Pereira, a Val, também foi uma grande amiga ao longo de toda esta travessia e a sua música, fruto da sua dedicação, paixão e talento, em várias ocasiões me deu forças para seguir em frente.

Às minhas amigas e "alunas", Juliana, Ana Luísa, Elisa e Kauara, que se desdobraram e se revezaram, em meio aos seus afazeres mis, para que cumpríssemos o propósito de lermos, juntos, como grupo de estudos, A verdade e as formas jurídicas. Suas reações, dúvidas e questionamentos foram, para mim, uma importante forma de me certificar sobre o escopo e o impacto de algumas das idéias que aqui aparecem. 
Ao meu pai, Alfonso, meus irmãos, Patrícia e António, meus amigos Mário e Tina Salimon, Márcio e Sandra Henriques, Philippe e Fernanda Seabra e à Mariza, pela torcida e pelo imprescindível apoio "moral".

À minha prima Itna Ibarra, que me deu um acolhedor pouso em Santiago, no meu caminho para o (e na volta do) pacífico (em todos os sentidos) balneário de Maitencillo, Chile, onde escrevi uma parte particularmente difícil desta tese.

À pesquisadora Célia Bernardes, por ter me mostrado formas mais modernas de fichamento, que não meus arcaicos caderninhos, e por ter me feito perder medo do Francês.

Ao prof. Renato Janine Ribeiro, por ter sugerido o tema deste trabalho.

Não seria justo deixar de fora desta lista a minha analista, Cíntia Xavier de Albuquerque, que tanto participou deste resultado, vendo a sua escrita—e tudo mais à sua volta-, nascer, crescer e chegar ao seu término—-tal como aconteceu com a nossa relação-, sem ter, evidentemente, qualquer responsabilidade ou mesmo (por mais que eu insistisse) cumplicidade teórica por seu conteúdo. A tendência a cometer tal injustiça, contudo, se justificaria porque, na verdade, minha gratidão para com a sua pessoa e o seu trabalho extrapola, em muito, o âmbito desta obra e porque não acho que possa ser expressa por meras palavras. 
"Que ahorcaran a alguien era-lo-que-era, sobraban las palabras, pero si ese álgiuen había sabido (y el refinamiento podía haber estado en decírselo) que una cámara iba a registrar cada instante de sus muecas y sus retorcimientos para deleite de dilettantes del futuro...'Por más que me pese nunca seré un indiferente como Etienne' pensó Oliveira. 'Lo que pasa es que me obstino en la inaudita idea de que el hombre ha sido creado para otra cosa. Entonces, claro...Qué pobres herramientas para encontrarle una salida a este agujero. ,” JÚLIO CORTÁZAR, Rayuela, Capítulo 15. 


\section{RESUMO}

IBARRA, Andrés Alfredo Rodríguez; Uma relação sempre atual: a liberdade recalcitrante de Michel Foucault. 2007. Tese (Doutorado) - Faculdade de Filosofia, Letras e Ciências Humanas, Universidade de São Paulo, 2007.

A presente tese parte da afirmação reiterada e desconcertante desse filósofo francês de que ele não seria, de modo algum, um "teórico do poder", para mostrar que, para além das discussões em torno de se o primeiro Foucault (da arqueologia dos saberes), o segundo (da genealogia do poder), ou o terceiro (da ética e das condutas individuas), seria o mais importante, o "melhor", é possível falar numa unidade no que diz respeito à trajetória do seu pensamento e que essa unidade se dá em torno das relações políticas entre os homens, o que faz com que ele seja, eminentemente, um pensador da política, ou melhor, do político. Só que a política tal qual ele a entende não tem nada a ver com a aquela dos teóricos da política ou do poder e, sim, com a relação que ele passou a perseguir em um determinado momento dessa trajetória: a relação entre governantes e governados. Essa relação, cuja percepção se tornou possível por meio do conceito de governamentalidade, gestado no ano de 1978, constitui-se numa nova "grade de leitura" para a política, que permite: 1) dar um basta à idéia de que haja, nesse âmbito, modelos universais que possam dar respostas a todos os tipos de questões-modelos esses que legitimam a existência de "intelectuais universais", incumbidos de conceber esses modelos e apresentá-los aos "explorados" e "ignorantes", prometendo-lhes a sua libertação, bem como da "vida política" nas atuais democracias representativas—; 2) conceber uma noção de liberdade-enquanto uma relação entre governantes e 
governados que não possui limites a priori-que escapa à da tradição liberal que, gestada nos séculos XVII-XVIII, se tornou hegemônica no Ocidente a partir do século XIX, não só no plano discursivo, mas enquanto realidade sócio-econômica global. Onde quer que existam essas relações-e elas sempre existirão, para Foucault, do micro ao macro-é necessário que seja possível, sempre, pô-las sob questão; o que só acontece quando o pensamento é deixado solto para ser capaz de levantar o maior número de conflitos possível—e não de consensos-; para, crítico, apontar o maior número de problemas a serem resolvidos dentro do âmbito dessas. Algumas dessas relações irão, então, se sustentar, conseguir se justificar; outras, não, terão que ser revistas, num interminável trabalho de extensão dos limites da liberdade humana. Essa nova noção de liberdade, por sua vez, traz consigo a possibilidade de interrogação do fenômeno da subjetividade, na medida em que são sujeitos, sempre, os que participam dessas relações entre governantes e governados. Por isso, o presente trabalho se esforça em mostrar percursos intelectuais que, tendo sido percebidos e diretamente abordados por Foucault (caso de Kant e de Platão) ou não (segunda clínica lacaniana e perspectivismo ameríndio), mantêm, na ênfase que dão ao sujeito, uma visada em comum com a empreitada foucaultiana.

PALAVRAS-CHAVE: Michel Foucault, liberdade, governamentalidade, intelectuais, poder, poder pastoral, atitude crítica, cuidado de si, subjetividade, história da verdade, segunda clínica lacaniana, perspectivismo ameríndio, corpo, ética. 


\begin{abstract}
IBARRA, Andrés Alfredo Rodríguez; An always current relationship: Michel Foucault's recalcitrant liberty. 2007. Thesis (Doctorate) - Faculdade de Filosofia, Letras e Ciências Humanas, Universidade de São Paulo, 2007.
\end{abstract}

This thesis initiates itself by the reiterated and astonishing declaration by this French philosopher that he would not be, under any circumstance, a "power theoretician", in order to show that, beyond the debates on whether it would be the first Foucault (the archeology of knowledge one), the second (genealogy of power one), or the third (the ethics and the individual conduct one), the most important one, the "best", it is possible to talk about a unity in what concerns the trajectory of his thought and that such unity concerns the political relations between men, which results in that he is, eminently, a thinker of politics, or rather, of the political. Except that politics as he understands it has nothing to do with that of the theorists of politics or of power but with a relationship that he began to pursue somewhere along such a trajectory: the relationship that exists between the governing and the governed. Such a relationship, whose perception became possible by means of the concept of governmentality, conceived in the year of 1978 , constitutes itself as a "grid of understanding" for politics, which allows to: 1) declare that we've had enough of the idea that there shall exist, in such domain, universal models that may answer all kinds of questions-models which legitimate the existence of "universal intellectuals", held responsible for conceiving such models and for presenting them to the "exploited" and "ignorant", promising their liberation, as well as of "political life" in current representative democracies-; 2) to conceive a notion of liberty-as a relationship between the governing and the governed which has no a priori 
limits-that escapes from the liberal tradition one which, created along the XVII/XVIII ${ }^{\text {th }}$ century, became hegemonic in the West since the XIX ${ }^{\text {th }}$ century, not only on the discursive level, but as socio-economic global reality. Wherever such relations exist—and they will always do, for Foucault, from micro to macro-it is necessary that it be possible, always, to put them open to question; that which only occurs when thought is left free to be able to raise the highest number possible of conflicts - and not consensuses-, in order to, critic as it is, point out the highest number of problems to be solved in such domain. Some of those relationships will be able, then, to sustain themselves, to justify themselves; others, won't, they will have to be modified, in an interminable labor of extending the limits of human liberty. This new notion of liberty, by its turn, carries along with itself the possibility of the inquiry of the phenomenon of subjectivity, as it is that it is always subjects that participate in such relations between the governing and the governed. For this reason, this thesis makes an effort to present intellectual paths which, having been noticed and approached by Foucault (the case of Kant and Plato) or not (second Lacanian clinic and Amerindian perspectivism), maintain, in the emphasis they give to the subject, a common viewpoint with the Foucauldian enterprise.

KEYWORDS: Michel Foucault, liberty, governmentality, intellectuals, power, pastoral power, critical attitude, care of the self, subjectivity, history of truth, second Lacanian clinic, Amerindian perspectivism, body, ethics. 


\section{RÉSUMÉ}

IBARRA, Andrés Alfredo Rodríguez; Un rapport toujours actuel : la liberté rétive de Michel Foucault. 2007. Thése (Doctorat) - Faculdade de Filosofia, Letras e Ciências Humanas, Universidade de São Paulo, 2007.

Cette thèse s'inicie par l'affirmation réitérée et surprenante de ce philosophe français de qu'il ne serait, aucunement, un «théoricien du pouvoir », pour montrer que, pour au-délà des discussions autour de si le prémier Foucault (celui de l'archéologie des savoirs), le second (celui de la généalogie du pouvoir), ou le troisième (celui de l'éthique et de la conduite individuelle), serait le plus important, le meilleur, il est possible de parler d'une unité en ce qui concerne la démarche de sa pensée et que cette unité se donne autour des rélations politiques entre les hommes, ce que fait qu'il soit, éminemment, un penseur de la politique, ou encore, du politique. Toutefois, la politique tel qu'il la comprend, n'a rien à voir avec ce des théoriciens de la politique ou du pouvoir, mais avec le rapport qu'il a passé a poursuivre dans un déterminé moment de cette démarche: le rapport entre gouvernants et gouvernés. Ce rapport, dont la perception est dévenu possible à travers le concept de gouvernementalité, conçu en 1978, se constitue dans une nouvelle «grille de lecture » pour la politique, qui permet de : 1) refuser l'idée de qu'il ait, dans ce domain, des models universaux qui puissent donner des réponses à tous le types de questions-models qui légitiment l'existence d' «intellectuels universaux », rendus responsables de concevoir ces models et de leur présenter aux «explorés » et «ignorants », en leur promettant leur libération, si bien que de la «vie politique » dans les démocracies representatives-;2) concevoir une 
notion de liberté—comme un rapport entre gouvernants et gouvernés qui n'a pas des limits à priori-qui échape à celle de la tradition libérale qui, conçue aux XVII-XVIII ${ }^{\mathrm{eme}}$ siècles, est devenu hégémonique en Occident dès le XIX $^{\text {eme }}$ siècle, pas seulement au plan discursif, mais en tant que réalité socio-économique globale. Partout que ces rapports existent—et ils existeront toujours, pour Foucault, du micro au macro—il est nécéssaire qu'il soit possible, toujours, les rendre sous question; ce qui ne se passe que quand la pensée est laissée libre pour être capable de lever le plus grand nombre possible de conflits—et pas de concensus_- pour, critique, dégager le plus grand nombre de problémes à être résous dans ce domaine. Quelques'uns de ces rapports iront, alors, se soutenir, être capable de se justifier; des autres, non, il faudra les réviser, dans un interminable travail d'extension des limites de la liberté humaine. Cette nouvelle notion de liberté, par son tour, porte avec soi l'interrogation sur le phénomène de la subjectivité, car ils sont de sujets, toujours, ceux qui participent des rapports entre gouvernants et gouvernés. Pour ce motif, ce travail s'efforce de montrer des parcours intellectuaux, qui, ayant eté notés par Foucault (le cas de Kant et de Platon) ou non (deuxième clinique lacanienne et perspectivisme amérindien), maintiennent, dans l'importance qu'ils donnent au sujet, une visée en commun avec l'entreprise foucauldienne.

MOTS CLÉS: Michel Foucault, liberté, gouvernementalité, intellectuels, pouvoir, pouvoir pastoral, attitude critique, souci de soi, subjectivité, histoire de la vérité, deuxième clinique lacanienne, perspectivisme amérindien, corps, éthique. 


\section{SUMÁRIO}

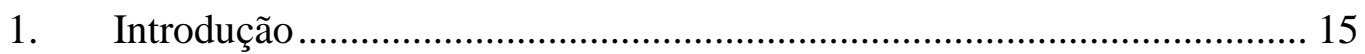

2. Parte I: A verdade do poder: um desvio necessário................................. 23

2.1. Capítulo 1: O poder e os intelectuais .................................................. 26

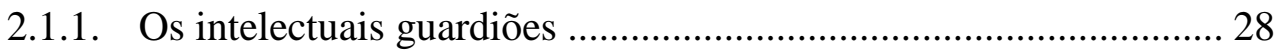

2.1.2. Prisão e Estado moderno ................................................................... 39

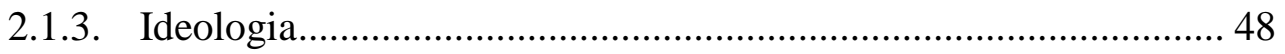

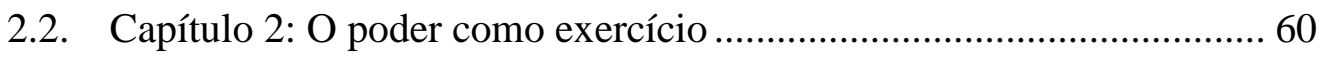

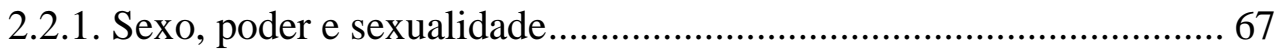

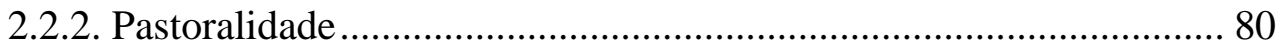

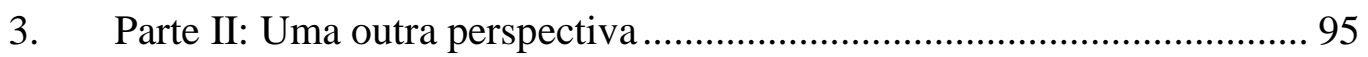

3.1. Capítulo 3: Política, Liberdade e Direito ................................................. 98

3.1.1. A periculosidade da liberdade ..................................................... 98

3.1.2. Governantes e governados, conflito e consenso ........................... 110

3.2. Capítulo 4: Modificações.................................................................... 128

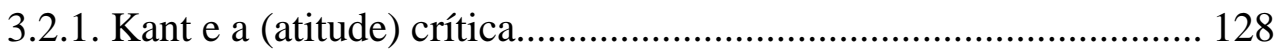

3.2.2. Platão e o cuidado de si ............................................................... 143

4. Parte III: Percussões .......................................................................... 163

4.1. Capítulo 5: Sujeito, corpo e coragem............................................. 168

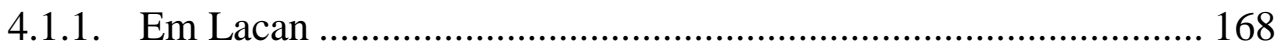

4.1.2. No pensamento ameríndio ..................................................... 182

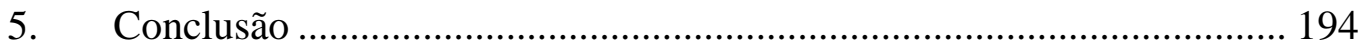




\section{Introdução}

Ao menos duas incertezas rondam os debates acerca do significado e do sentido da obra de Michel Foucault. A primeira diz respeito a haver nela uma continuidade ou uma ruptura, a ser ela um corpo só que, com o tempo, amadurece, ou um conjunto de "fases" que, entre si, mantêm distância, não se comunicam devido a uma (ou mais de uma) radical mudança ocorrida em um instante específico. A segunda diz respeito ao lugar no qual, dentro do leque de campos de que é composta a filosofia, cabe encaixar essa obra.

No que diz respeito à primeira dessas incertezas, encontramo-la, no âmbito brasileiro, abordada na obra de uma reconhecida estudiosa e tradutora de Foucault, Salma Tannus Muchail, que inicia a coletânea de textos seus a respeito desse autorFoucault, simplesmente — com um em que tematiza essa "trajetória" para, no seu final, concluir que tanto uma quanto outra vertente tem o seu lugar:

"pode-se (...) compreender a reunião dos três momentos da trajetória de Foucault em um mesmo conjunto, sem contudo escamotear suas diferenças: o primeiro momento interroga o que habitualmente se entende por 'progresso do conhecimento', conduzindo à análise da práticas discursivas constitutivas dos saberes reconhecidos como verdadeiros; o segundo interroga o que habitualmente se entende por 'poder', conduzindo à análise dos mecanismos de exercícios dos poderes relacionados à produção de saberes; o terceiro momento interroga o que habitualmente se entende por 'sujeito', conduzindo à análise da 'constituição de si mesmo como sujeito'. Ou pode-se, inversamente, enumerar os momentos dessa trajetória acentuando as diferenças sem necessariamente perder suas conjunções: trata-se, como indica um estudioso de Foucault, de três campos ou continentes de reflexão, um mais marcadamente epistemológico, outro político, outro ético; ou trata-se, como se exprime o mesmo Foucault, de três ordens de problemas, 'o da verdade, o do poder e o da conduta individual'."

\footnotetext{
${ }^{1}$ MUCHAIL, Salma Tannus; Foucault, simplesmente—textos reunidos; São Paulo, Edições Loyola, 2004, pp. 19-20.
} 
O presente trabalho se inscreve na linha daqueles que acreditam que as “conjunções" não podem ser "perdidas" e que, conseqüentemente, as "diferenças"—elas existem, de fato? - podem ser, sim, “escamoteadas”. É claro, não há como ir contra o próprio Foucault, que acreditou, num primeiro momento, que a arqueologia do saber seria uma ferramenta suficientemente poderosa de transformação; que logo, num segundo momento, a deixou de lado, depositando as fichas na genealogia do poder para, finalmente, abrir um terceiro campo de investigação, uma terceira forma de proceder, atenta a outros tipos de fenômenos, éticos. A questão não passa por aí, mas sim em perguntar o que é que rende mais e o que está mais de acordo com o que o próprio corpo da obra indica—pois, igualmente, o próprio Foucault, como veremos, deu declarações importantes, devidamente apontadas, diga-se de passagem, por Muchail, que vão no sentido de que ele teria, no fundo, sempre feito uma única e mesma coisa. Mergulhar nas diferenças, esquecendo as continuidades parece-nos próximo a enfatizar uma preocupação excessivamente metodológica-pois, tanto a arqueologia do saber quanto a genealogia do poder e a do sujeito, enquanto ângulos de abordagem, são metodologias-que deixa escapar o que há de mais rico—não que a questão, metodológica, desses três momentos não o seja—em termos de legado intelectual. Em outras palavras: se é o próprio Foucault quem está dizendo que o que ele "sempre fez" foi "isso"- ainda que ele só venha a ter se dado conta disso numa análise retrospectiva—como não dar atenção a essa ou esse tipo de afirmação, como não seguir a direção que ela indica?

Este trabalho é o resultado de uma hipótese: a de que a questão da liberdade, questão essa que surge no pensamento desse autor no ano de 1978, é o que, estando intimamente atrelada a esse "isso" que ele "sempre fez", lhe permitiu , depois de tantas 
andanças, de tantos estudos realizados ao longo de duas décadas, encontrar um eixo identitário, uma espécie de chave com a qual esse autor conseguiu, finalmente, compreender o que ele tinha feita até então—e o que gostaria de fazer daí em diante.

É freqüente se ouvir que a sua produção posterior à publicação de $A$ vontade de saber-volume I da História da sexualidade, publicado em 1976-teria declinado e, nisso, atribui-se uma culpa ao seu estado de saúde-Foucault morreu em 1984, vítima da AIDS —o que, igualmente, poderia explicar o fato de ele ter freado o seu ritmo de publicações-ele viria a publicar somente mais dois livros, já no seu leito de morte, simultaneamente, em 1984, ao passo que, somente na década de setenta, já havia publicado dois. Este trabalho demonstra o contrário: que os oito anos transcorridos entre a publicação do volume I e a dos volumes II e III da História da sexualidade, são anos de intensa e rica produção e que a desaceleração no "ritmo" de publicação se deveu a uma lenta e progressiva inflexão conceitual, registrada no transcorrer dos cursos que ele deu, ao longo desses anos, no Collège de France, cujas degravações vêm vindo a público nos últimos anos; inflexão essa que é precisamente a que diz respeito à noção de liberdade.

Isso nos conduz à segunda das incertezas apontadas acima: qual é o lugar de Foucault nesse vasto campo que é o da filosofia? A edição brasileira, resumo da francesa, dos Ditos e escritos ${ }^{2}$ —a publicação póstuma de tudo, entrevistas, artigos, conferências, manifestos, o que Foucault disse e escreveu entre os anos de 1954 e 1984-subdivide-se em cinco partes: 1) problematização do sujeito: psicologia , psiquiatria e psicanálise; 2) arqueologia das ciências e história dos sistema de

\footnotetext{
${ }^{2}$ FOUCAULT, Michel; Dits et écrits, vols. I et II, édition établie sous la direction de Daniel Defert et François Ewald avec la collaboration de Jacques Lagrange ; Paris, Quarto-Gallimard, 2001. Doravante, referida pela sigla $D E$, sempre seguida da indicação do volume.
} 
pensamento; 3) estética: literatura e pintura, música e cinema; 4) estratégia, poder-saber e 5) ética, sexualidade e política. Já a edição norte-americana, também uma seleção, divide-se em três partes: 1) ética; 2) estética, método e epistemologia e 3) poder. São indicações, recortes de um todo bastante abrangente, do qual não creio que seja o caso de dizer: essa ou aquela parte é a mais importante, este ou aquele conjunto é o principal; mas, sim, procurar ver se não há algo que vincula isso tudo, se não há um elemento que perpassa esse conjunto todo, tão vasto. Ora, este trabalho imbui-se da crença na idéia de que o lugar, por excelência, que a obra de Foucault deve ocupar no âmbito das subdivisões de que o universo filosófico é, atualmente, composto, esse lugar é o da filosofia política. E isso não somente porque esse tema que tento mostrar ser a chavemestra dessa obra, a liberdade, ser um tema, por excelência, do pensamento políticoesse é um "encaixe", eu diria, meramente, teórico e, como ver-se-á, a teoria não é tudo-, mas, porque as entrevistas, artigos e demais textos que encontramos nos Ditos e escritos deixam entrever e nos ajudam a reconstruir um Foucault inteiramente sintonizado com a política a ele—e a nós, já que não estamos assim tão distantescontemporânea. Assim, creio que seja possível ler qualquer um dos textos desses Ditos e escritos, bem como qualquer um dos livros de Foucault, mesmo os mais distantes desse período em que a liberdade passa a vigorar como elemento de preocupação, à luz de uma política e à luz de uma liberdade.

Essa forma de proceder, creio, nos imuniza de uma tendência recorrente, não tanto entre filósofos, mas no meio da ciências humanas-nesse âmbito para o qual Foucault olhava com extrema desconfiança-: o de tomar tal ou qual aspecto da obra desse autor e dizer que ele é "útil", que ele "serve" para explicar essa ou aquela realidade, como se "a realidade" fosse o mais importante e não o como e até que ponto é 
possível e desejável transformar essa "realidade". Era com isso último, com a transformação, que, como veremos, Foucault estava comprometido e é por isso que sua obra não cabe em outro lugar, que não o da filosofia política-o que tampouco quer dizer que, nela, não nos deparemos com a mais erudita das realizações acadêmicas, com o mais atento dos olhares em direção à realidade que nos cerca ${ }^{3}$.

Mas, dizer que Foucault é um autor, de cabo a rabo, político, não quer dizer que ele esteja de acordo com a política tal qual ela existe nos dias atuais, que ele acredite, ao menos um pouco, que ela seja capaz de qualquer transformação. É por esse ponto que este trabalho começa, ao mostrar o distanciamento de Foucault em relação a algo que chamo de "a verdade da política", uma verdade que, em larga escala, é produzida e reproduzida, é mantida, assegurada, nutrida, por certos "guardiões", que veremos quem são-e que não são "os políticos”. Veremos, igualmente, que, em certo momento, Foucault correu um sério risco de se tornar um desses "guardiões"; e que foi nesse momento, ao escapar dessa "arapuca", que ele começou a sair de uma posição na qual, a respeito dela, a política, ele só falava indiretamente, para assumir, cada vez mais, uma posição afirmativa, onde todo um otimismo que já se deixava entrever no desenho de sua “máquina arqueológica”- “"no fundo, minha máquina é boa; não na medida em que ela transcreve ou fornece o modelo do que se passou, e sim na medida em que ela

\footnotetext{
${ }^{3}$ Um bom exemplo disso se encontra numa conversa que Foucault manteve com geógrafos, em 1975, na qual esses começam lhe perguntando sobre o motivo de ele ter tematizado muito pouco, quase nada, até aquele momento, a geografia nos seus livros e artigos; ele então responde que "abordar uma ciência porque ela é interessante, porque ela é importante ou porque a sua história teria alguma coisa de exemplar, isso não me parece um bom método. É sem dúvida um bom método se se quer fazer uma história correta, própria, conceitualmente asseptizada. Mas, a partir do momento em que se quer fazer uma história que tem um sentido, uma utilização, uma eficácia política, só se pode fazê-la corretamente sob a condição de que se esteja ligado, de uma maneira ou de outra, aos combates que se travam dentro desse domínio. Aquilo de que eu tentei fazer a genealogia foi, de início, a psiquiatria, porque eu tinha uma certa prática e uma certa experiência do hospital psiquiátrico e porque eu percebia que aí havia combates, linhas de força, pontos de enfrentamento, tensões. A história que eu fiz, só a fiz em função desses combates. A questão, o motivo, o desafio sendo o de poder sustentar um discurso verdadeiro e que seja estrategicamente eficaz; ou, ainda, como a verdade da história pode ter, politicamente, seu efeito." (FOUCAULT, Michel; "Questions à Michel Foucault sur la géographie", in DE II, texto no 169, p. 29.)
} 
consegue dar do que se passou um modelo tal que permita que nos libertemos do que se passou", diz ele na mesa-redonda que se seguiu, em 1973, no Rio de Janeiro, às conferências sobre "A verdade e as formas jurídicas" — passa a adquirir os contornos, como afirma em 1978, de um "otimismo absoluto":

“eu não admito nem a noção de domínio, nem a universalidade da lei. Ao contrário, eu me dedico a capturar os mecanismos de exercício efetivo do poder; e eu o faço porque aqueles que estão inseridos nessas relações de poder, que nelas estão implicados podem, nas suas ações, na sua resistência e na sua rebelião, delas escapar, transformá-las, em suma, não mais se sujeitar. E se eu não digo o que é preciso fazer, não é porque eu ache que não há nada a se fazer. Muito pelo contrário, eu penso que há mil coisas a se fazer, a se inventar, a se forjar por parte daqueles que, reconhecendo as relações de poder nas quais estão implicados, decidiram resistir a elas ou delas escapar. Sob esse ponto de vista, toda a minha busca repousa sobre um postulado de otimismo absoluto." ${ }^{\text {}}$

Isso pode soar muito estranho aos ouvidos de quem, depois de Vigiar e punir e de A vontade de saber-livros onde a temática do poder é abordada de forma direta e, como veremos, também, nova, na medida em que ele passa a ser visto enquanto exercício-, viu-o mergulhar na Grécia Antiga e nas questões da moral sexual vigente nesse local e época. Esse mergulho em muito contribui para que se formule um julgamento do tipo: Foucault, que estava indo tão bem nos seus estudos e nas suas denúncias sobre o poder e sobre os micropoderes, acabou por recuar, "tirou o seu time de campo" e terminou seus dias na agradável companhia dos gregos ${ }^{6}$. Ora, o que a segunda parte deste trabalho mostra—apoiando-se nas degravações dos cursos de 1978 e 1979—é que de fato ocorreu o contrário: se temas relativos ao Estado moderno, a políticas públicas e política econômica, na produção dita genealógica, eram, em grande

\footnotetext{
${ }_{5}^{4}$ FOUCAULT, Michel; A verdade e as formas jurídicas; Rio de Janeiro, Nau Editora, 2002, p. 157.

${ }^{5}$ FOUCAULT, Michel; "Entretien avec Michel Foucault", in DE II, texto no281, pp. 911-912.

${ }^{6}$ É algo mais ou menos assim que lemos na introdução de Homo sacer, de Giorgio Agambem, quando ele diz que a pesquisa deste teria deixado o legado de uma "sombra" ou um "ponto cego", na ausência que demonstra de um "centro unitário" para o "duplo vínculo", que ela mesma aponta, entre técnicas de "individuação" e procedimentos de "totalização das estruturas do poder" e que vale a pena investir, como ele então anuncia fazer, na junção dessas duas análises para formular uma só, em que se investiga a hipótese de que "a produção de um corpo biopolítico seja a contribuição original do poder soberano." (AGAMBEM, Giorgio; Homo sacer-o poder soberano e a vida nua I; Belo Horizonte, Editora UFMG/Humanitas, 2002, pp. 13-14).
} 
parte, ignorados - com Foucault dizendo e mostrando, pertinentemente, que a questão não estava aí, em encontrar um "modelo" que iria responder a todas as necessidades-, o que se vê, nesses cursos, é um Foucault sendo capaz de abordar tais questões, mas só que sob um ângulo extremamente singular e novo, por meio de toda uma nova "grade de leitura", em cujo cerne, como tento mostrar, está a questão da liberdade. Foi esse trabalho-um desenvolvimento ulterior e inesperado, para ele próprio, um desdobramento, do seu trabalho sobre os micropoderes- que, tendo lhe proporcionado uma nova forma de ler o poder e seu exercício, fez com que ele tivesse que, ou, ao menos, achasse mais conveniente, ir pesquisar os gregos, atrás do surgimento desse poder ao qual ele passou a dar o nome de "poder pastoral". Tudo, sob o signo da mais pura paixão e do mais ardente entusiasmo que sempre foram, aliados a um rigor intelectual e a uma inquebrantável disposição para o trabalho, a sua marca registrada.

Em meio a esse mergulho, duas redescobertas, a de Kant e a de Platão, dois autores possivelmente, contemporaneamente, também vistos como "velhos", por vezes ultrapassados—e não se pode dizer que Foucault não tenha tido um papel, ainda que pequeno, nisso, dados o seu nietzscheanismo e o que ele havia escrito sobre Kant em As palavras e as coisas. Temos, então, como será visto, um Foucault que encontra novos interlocutores, desta vez filósofos "de carteirinha"-e não mais os "anti-filósofos" que lhe tinham aberto tantas portas no começo da sua caminhada ${ }^{7}-$, o que demonstra, mais uma vez, uma abertura para o que está para além de si, uma eventual demonstração de que, por mais que se saiba, o mais sábio dos sábios é aquele que se admite ignorante.

E é, bastante, nessa condição, a de ignorante, que eu me lanço, na última parte deste trabalho, à procura de confluências entre o pensamento de Foucault a respeito da

\footnotetext{
${ }^{7}$ A esse respeito, cf. infra, nota $n^{\circ} 328$.
} 
liberdade e dois outros percursos intelectuais, mais ou menos contemporâneos a ele, que se situam nas esferas da psicanálise e da etnologia. Dou a isso o nome de "percussões", um termo que tomo emprestado de Foucault, que o usou em uma visita feita ao Japão, em 1978, quando se hospedou em um mosteiro zen-budista ${ }^{8}$, e que tem, como uma de suas acepções, segundo o Houaiss, a de "exame físico que consiste em provocar certos sons em uma área do corpo por meio de pequenos golpes com instrumento próprio ou com os dedos; sua finalidade é a de reconhecer o estado de partes subjacentes à área examinada". Não sei até que ponto esse sentido, médico, desse termo é o que corresponde ao que Foucault quis usar em tal ocasião, mas, de toda forma, creio que ele nos dá uma imagem dupla bastante interessante: a de que, como num corpo que abriga diversos órgãos, culturas humanas diversas (no caso de Foucault) e trajetórias do pensamento idem (no presente trabalho), podem configurar uma única e mesma coisa (em que culturas ou trajetórias podem "subjazer" umas às outras), talvez até mesmo uma mesma luta ou combate; e a de que mesmo Foucault, esse filho de médico, que em determinado momento-em $O$ nascimento da clínica, livro de 1963 -montou a sua trincheira crítica no espaço dos saberes médicos, sucumbiu, ao menos uma vez, à influência paterna.

${ }^{8}$ Cf. infra, nota $\mathrm{n}^{\circ} 281$. 


\section{Parte I: A verdade do poder: um desvio necessário}

Dentre os diversos desconcertos provocados por Foucault ao longo da sua trajetória intelectual—desconcertos que configuram uma marca desse autor, dessas que nos dão um rosto ${ }^{9}$ : “minha maneira de não ser mais o mesmo é, por definição, a parte mais singular daquilo que sou" ${ }^{10}$ - possivelmente o maior esteja nas suas declarações dos seus últimos anos (a primeira data de 1982) de que ele não é, de forma alguma, um teórico do poder ${ }^{11}$. Desconcerto, certamente, para todos os que o ouviam, há mais de uma década, falar ininterruptamente sobre esse tema, perseguí-lo com obstinação, levantar sobre ele aspectos, testar a seu respeito hipóteses, romper com visões assentadas, a ele relativas. Desconcerto tão grande que beira a possibilidade de aí estar, nessas declarações, uma prova de que esse filósofo é mais um desses que, chegada uma certa idade, caducam, ou, pior, desses que não devem ser levados a sério, posto que não mantêm uma coerência, que se contradizem contra a própria vontade. Estaria aí, nessa eventual ausência de rigor, a fonte de uma riqueza, algo que deveria estar presente em toda filosofia? Pensar assim talvez seja confundir abertura para o novo com deficiência lógica, curiosidade com inconsistência ou falta de compromisso, irresponsabilidade.

\footnotetext{
9 "Um pensamento desconcertante" é o subtítulo do volume da revista Tempo Social dedicado a Foucault (Tempo Social; São Paulo, v. 7, n. 1-2, outubro 1995). É também, sob o nome de "o inesperado", o objeto a partir do qual Renato Janine Ribeiro constrói a sua reflexão, em seu ensaio a respeito desse pensador, fazendo uso, para tanto, de uma teoria da fritura, exposta em Brillat-Savarin (RIBEIRO, Renato Janine, "O discurso diferente", in RIBEIRO, Renato Janine; A última razão dos reis; São Paulo, Companhia das Letras, 2002, pp. 71-81).

${ }^{10}$ FOUCAULT, Michel; "Pour une morale de l'inconfort", in DE II, texto n ${ }^{\circ}$ 266, p. 784.

${ }^{11}$ A primeira dessa declarações está em "Le sujet et le pouvoir" (FOUCAULT, Michel; DE II, texto n ${ }^{\circ}$ 306, pp. 1041-1062), texto que ele já abre dizendo que o objetivo do seu trabalho nos últimos vinte anos "não foi o de analisar os fenômenos de poder nem de lançar as bases de uma tal análise", para, em seguida, dizer: "Não é, portanto, o poder, mas o sujeito, que constitui o tema geral das minhas pesquisas." (Idem, pp. 1041-1042). A segunda, de 1983, em "Structuralisme et poststructuralisme" (FOUCAULT, Michel; $D E I I$, texto n ${ }^{\circ} 330$, pp. 1250-1277) é onde ele diz, textualmente: "eu não sou de modo algum um teórico do poder." (p. 1270)
} 
Não há contradição nenhuma nessas declarações desde o momento em que se perceba aquilo que o próprio Foucault teve dificuldade em perceber, mas que acabou fazendo e tendo a coragem de dizê-lo publicamente: que ele tinha andado e andado, mas que ao final de tantas andanças, tinha terminado "na vertical de si mesmo"12. O poder, a sua pesquisa a seu respeito, poderia ser vista como uma longa aventura, um longo desvio que ele teve que fazer numa trajetória, a sua, que é alheia ao seu circuito (o poder), que não é a da investigação a seu respeito, que não é a sua "teoria"? Poderia ser um desvio, mas um desvio inevitável para as pretensões desse pensador das "relações entre verdade e sujeito" ${ }^{\prime 13}$ ? Nada a respeito do que ele tenha se arrependido ou considerado um erro? Uma necessidade, que, por sua vez, permitiu-lhe encontrar um conjunto de novas definições para conceitos tidos como velhos por ele mesmoconceitos que ele combateu com afinco e contra os quais ergueu, de início, o seu pensamento, a sua filosofia-, como "liberdade" e "sujeito"? Cabe, para darmos resposta a essas indagações, iniciar com a importância que o poder tem nesse pensamento.

Em Foucault, chega-se à formulação de uma perspectiva inteiramente inovadora a respeito do poder, uma que vislumbra aproximar a sua apreensão àquela que os filósofos analíticos da linguagem formularam com respeito a essa, enfatizando o seu uso, e não a sua essência, sua estrutura ou o seu ser. É a proposta de um novo mundo para o conhecimento, a possibilidade de um novo saber, algo que nos aproxima da "revolução copernicana" proposta por Pierre Clastres no seu ensaio "Copérnico e os

\footnotetext{
${ }^{12}$ FOUCAULT, Michel; Histoire de la sexualité, vol II-L'usage des plaisirs; Paris, Gallimard, 2004, p. 19.

${ }^{13}$ Definição que está na mesma entrevista de 1983 e que será esmiuçada mais adiante, nas partes II e III desta tese.
} 
selvagens" ${ }^{14}$, em que ele especula sobre uma inversão da centralidade na relação entre poder e história (esta última entendida no sentido de mudança, de inovação), passando o primeiro a ser determinante da segunda—e não o contrário, como nos quer ensinar toda uma tradição que não começa necessariamente com Marx ${ }^{15}$. Pode-se pensar num saber tecnológico sobre o poder, que diga respeito ao seu uso, que teria a capacidade de, conforme o desejado, provocar ou não—como nas sociedades indígenas das terras baixas amazônicas—mudanças nas sociedades, trazer a inovação histórica ou não, em vez de tê-las como pressupostos. Não é pouca coisa esse pensamento sobre o poder-e nem poderia sê-lo, sendo Foucault um herdeiro de Nietzsche.

${ }^{14}$ CLASTRES, Pierre; A sociedade contra o social; São Paulo, Cosac \& Naify, 2003, pp. 23-41.

15 Clastres fala de uma inversão da "idéia de Durkheim (...) para quem o poder político supunha a diferenciação social" e acrescenta: "não seria o poder político que constitui a diferença absoluta da sociedade?" (Idem, p. 40) Suas pesquisas a respeito das sociedades ameríndias, das chamadas terras baixas amazônicas, levam-no, nesse ensaio, a aventar a hipótese de que nelas se dê uma forma diferente de poder, uma forma não-coercitiva. O poder, portanto, teria diversas formas, diversas possibilidades (ou, pelo menos, duas, dependendo do uso que faça ou não da força), o que, por sua vez, seria o que determina a existência ou não de mudança nas sociedades - de diferenças sociais e, conseqüentemente, de conflito, o elemento gerador da mudança. "Que uma mudança completa de perspectiva seja necessária (na medida em que se tenha realmente de enunciar sobre as sociedades arcaicas um discurso adequado a seu ser e não ao ser da nossa) é o que parece demonstrar com riqueza a antropologia política. Ela se choca com um limite, menos os das sociedades primitivas do que aquele que traz em si mesma, a própria limitação do Ocidente que ela traz ainda gravada em si. Para escapar à atração de sua terra natal e se elevar à verdadeira liberdade de pensamento, para se desvencilhar da evidência natural onde ela continua a debater-se, a reflexão sobre o poder deve operar a conversão 'heliocêntrica': ela ganharia talvez a melhor compreensão do mundo dos outros e, em consequiência, do nosso." (Idem, ibid.) Esse texto de Clastres foi inicialmente publicado em 1969, em forma de artigo e, em seguida, em 1974, em forma de livro. Alguns anos depois, em 1976, numa conferência na Bahia, Foucault faz uma crítica ao apego do pensamento social—incluindo aí sociólogos, psicólogos, psicanalistas e etnólogos-a uma concepção jurídica do poder e anuncia que vai mostrar "em que direção pode-se desenvolver uma análise do poder que não seja simplesmente uma concepção jurídica, negativa do poder, mas uma concepção de uma tecnologia do poder." Ele então faz referência à obra de Clastres, um exemplo de onde aparece "toda uma nova concepção do poder como tecnologia, que tenta se emancipar do primado, desse privilégio da regra e da proibição que, no fundo reinou sobre a etnologia desde Durkheim até Lévi-Strauss." (FOUCAULT, Michel;“"Les mailles du pouvoir” DE II, texto n²97, pp. 1002-1003) 


\title{
2.1. Capítulo 1: O poder e os intelectuais
}

\begin{abstract}
"Se quisermos realmente conhecer o conhecimento, saber o que ele é, apreendê-lo em sua raiz, em sua fabricação, devemos nos aproximar, não dos filósofos mas dos políticos, devemos compreender quais são as relações de luta e poder. E é somente nessas relações de luta e de poder - na maneira como as coisas entre si, os homens entre si se odeiam, lutam, procuram dominar uns aos outros, querem exercer uns sobre os outros, relações de poder-que compreenderemos em que consiste o conhecimento."16
\end{abstract}

Essas palavras, de inspiração profundamente nietzscheana, proferidas por Foucault em 1973, podem muito bem resumir seu percurso, os livros que ele havia publicado até o final dos anos '60, seus estudos até então. Foucault teve como mestres os filósofos e historiadores da ciência franceses, como Gaston Bachelard (indireto) e Georges Canguilhem (direto) e, à exceção de Raymond Roussel-livro dedicado a destrinchar a obra desse romancista francês—, todos os seus livros dessa década dizem respeito a esferas particulares do conhecimento, a saberes determinados e à metodologia por ele utilizada (a arqueologia) para poder analisá-los: a psiquiatria, a medicina, as ciências humanas. No momento em que profere essas palavras, um passo estava sendo dado: existe a questão do poder por trás do conhecimento, por trás daquilo que esteve no centro da sua atenção até então. Isso, Foucault não disse nesses livros e estudos "arqueológicos”, não era a sua prioridade. Intuía-o, certamente. Agora, estava na hora, uma vez consolidadas algumas dessas "histórias" de determinados "conhecimentos", de apontar e de pensar, a partir delas, esse tema subjacente e comum ${ }^{17}$. Mas, dizer que devemos nos aproximar dos políticos a fim de conhecer esse algo, o conhecimento, que vinha sendo o tema-mor de suas pesquisas até então, não quer dizer que Foucault fosse

\footnotetext{
${ }^{16}$ FOUCAULT, Michel; A verdade e as formas jurídicas, op. cit., p. 23.

17 Adiante veremos dois momentos "arqueológicos" em que Foucault aponta para tal perspectiva, mas sempre sem se aprofundar no assunto.
} 
tornar algo próximo a um cientista político, preocupado com coisas como a representação política, os partidos, a democracia. Não é de uma pesquisa sobre as verbas que os políticos de um determinado corpo político designam no orçamento à educação, à ciência e tecnologia ou à cultura, por exemplo, aquilo de que se trata, por ocasião dessas palavras.

O que elas querem dizer afinal? Se não é nem aos filósofos, nem aos políticos de partido àqueles que devemos olhar para conhecer o conhecimento, a quem devemos fazê-lo? Quem são esses "políticos" de quem ele está falando e de que devemos nos aproximar? Eles existem, ou o significado, a intenção de Foucault ao dizê-las é meramente um efeito retórico baseado numa metáfora? Esta segunda hipótese talvez seja a mais plausível: ele quer dizer que saber é poder, que ambos estão profundamente imbricados. Mas, o começo da década de setenta é também o começo de uma longa história dentro do universo da obra desse pensador: a do tema dos intelectuais. A análise do poder e a preocupação com o que é o papel dos intelectuais são duas linhas que caminham juntas, que surgem em concomitância e que não vão se separar nunca na obra desse autor $^{18}$. É a partir dessa relação em simetria que podemos, não sem afirmar

\footnotetext{
${ }^{18}$ É necessário que fique claro que a presente acepção refere-se à forma à qual Foucault, como veremos adiante, faz referência em diversos momentos ao longo dos anos '70 e que não coincide com a acepção sociológica do intelectual, que, a rigor, pode ser datada do século XII, como mostra Jacques Le Goff em Os intelectuais na Idade Média-e que pode ser aproximada da figura do "intelectual específico" defendida pelo próprio Foucault-: um "homem de ofício" que surge com o desenvolvimento das cidades, quase um trabalhador manual, incumbido do ensino e da pesquisa e ligado à produção mais do que à proteção ou à religião (cf. LE GOFF, Jacques; Os intelectuais na Idade Média; Rio de Janeiro, José Olympo, 2003, p. 13). Com o tempo, a partir dos anos '80 fundamentalmente, a referência à figura do intelectual, ou melhor, dos intelectuais, no plural, nas entrevistas que concedeu, passa a se dar em torno desta outra acepção, tal como dá conta o que diz numa delas, de 1980: "A palavra intelectual me parece estranha. Intelectuais, jamais os encontrei. Já encontrei pessoas que escrevem romances, e outras que cuidam dos doentes. Pessoas que fazem estudos econômicos e outras que compõem música eletrônica. Encontrei pessoas que ensinam, pessoas que penteiam e outras que não compreendi bem se faziam o que quer que seja. Mas intelectuais, jamais. Em compensação, encontrei muitas pessoas que falam do intelectual. E, à força de escutá-las, me fiz uma idéia do que poderia ser esse animal. Não é difícil, é aquele que é culpável. Culpável um pouco de tudo: de falar, de calar, de não fazer nada, de se meter em tudo... Em suma, o intelectual é a matéria prima do veredicto, da sentença, da condenação, da exclusão." (FOUCAULT, Michel; "Le philosophe masqué", in DE II, texto no 285, p. 924.)
} 
algo que Foucault não disse, pensar na possibilidade de ser essa figura, a do intelectual, um dos principais agentes dessa constatação feita por Foucault, quando ele vincula conhecimento e poder; de ser ele um daqueles elementos, políticos, para o qual devemos conduzir o nosso olhar a fim conhecer de verdade o conhecimento e o seu sentido, ou melhor, de ser ele um dos elementos, por excelência, que realiza o vínculo entre saber e poder, um dos elementos por meio do qual se torna mais fácil perceber tal ligação.

\subsubsection{Os intelectuais guardiões}

Em $A$ arqueologia do saber, Foucault chama a atenção para o componente político que a análise discursiva calcada no enunciado, tal como proposta por ele nesse livro, traz à tona:

\footnotetext{
"analisar uma formação discursiva é procurar a lei de sua pobreza, é medi-la e determinar-lhe a forma específica. É, pois, em um sentido, pesar o 'valor' dos enunciados. Esse valor não é definido por sua verdade, não é avaliado pela presença de um conteúdo secreto; mas caracteriza o lugar deles, sua capacidade de circulação e de troca, sua possibilidade de transformação, não apenas na economia dos discursos, mas na administração, em geral, dos recursos raros. Assim concebido, o discurso deixa de ser o que é para a atitude exegética: tesouro inesgotável de onde se pode tirar sempre novas riquezas, e a cada vez imprevisíveis; providência que sempre falou antecipadamente e que faz com que se ouça, quando se sabe escutar, oráculos retrospectivos. Ele aparece como um bem-finito, limitado, desejável, útil—que tem suas regras de aparecimento e também suas condições de apropriação e de utilização; um bem que coloca, por conseguinte, desde sua existência (e não simplesmente em sua 'aplicações práticas'), a questão do poder; um bem que é, por natureza, o objeto de uma luta, e de uma luta política." 19
}

${ }^{19}$ FOUCAULT, Michel; A arqueologia do saber; Rio de Janeiro, Forense Universitária, 1986, p. 139. 
Em As palavras e as coisas, também temos algo parecido, em meio à exploração desses

discursos que margeiam as chamadas ciências humanas:

\begin{abstract}
"afora as morais religiosas, o Ocidente só conheceu sem dúvida, duas formas de ética: a antiga (sob a forma do estoicismo ou do epicurismo) articulava-se com a ordem do mundo e, descobrindo sua lei, podia deduzir o princípio de uma sabedoria ou uma concepção da cidade: mesmo o pensamento político do século XVIII pertence ainda a essa forma geral; a moderna, em contrapartida, não formula nenhuma moral, na medida em que todo o imperativo está alojado no interior do pensamento e de seu movimento para captar o impensado; é a reflexão, é a tomada de consciência, é a elucidação do silencioso, a palavra restituída ao que é mudo, o advento à luz dessa parte de sombra que furta o homem a si mesmo, é a reanimação do inerte, é tudo isso que constitui, por si só, o conteúdo e a forma da ética. O pensamento moderno jamais pôde, na verdade, propor uma moral: mas a razão disso não está em ser ele pura especulação; muito ao contrário, desde o início e na sua própria espessura, ele é um certo modo de ação. Deixemos falar aqueles que incitam o pensamento a sair de seu retiro e a formular suas escolhas; deixemos agir aqueles que querem, sem qualquer promessa e na ausência de virtude, constituir uma moral. Para o pensamento moderno não há moral possível; pois, desde o século XIX, o pensamento já 'saiu' de si mesmo em seu ser próprio, não é mais teoria; desde que ele pensa, fere ou reconcilia, aproxima ou afasta, rompe, dissocia, ata ou reata, não pode impedir-se de liberar e de submeter. Antes mesmo de prescrever, de esforçar um futuro, de dizer o que é preciso fazer, antes mesmo de exortar ou somente alertar, o pensamento, ao nível de sua existência, desde a sua forma mais matinal, é, em si mesmo, uma ação-um ato perigoso." 20
\end{abstract}

Mas, poder-se-ia dizer que quando pratica a arqueologia do saber, quando mostra os saberes sobre o louco, sobre a doença, sobre o homem, sob o ponto de vista dos enunciados que os compõem, é dos discursos de intelectuais que se está tratando? Parece que não: assim como o psiquiatra, como o clínico, como o lingüista, como o economista e como o biólogo são figuras que aparecem num determinado momento que Foucault cuida em descrever arqueologicamente- e o qual ele consolida sob o nome de “episteme moderna”- há um momento em que aparece essa figura, o intelectual, que não é bem o agente por excelência dessa nova episteme, não é o seu tipo ideal, nem aquele sob o qual esses outros poderiam ser classificados. O intelectual, tal como Foucault a ele se refere no começo dos anos '70 tem uma especificidade, que não

${ }^{20}$ FOUCAULT, Michel; As palavras e as coisas—uma arqueologia das ciências humanas; São Paulo, Martins Fontes, 2002, pp. 452-453. 
coincide com a desses outros produtores de conhecimento. E essa especificidade está vinculada intimamente àquilo que passa a ser seu novo interesse: o poder.

Como é que isso se dá? Ora, acontece que o poder, esse fenômeno sobre o qual Foucault não é o primeiro a falar, possui discursos a seu respeito, discursos que não se distanciam daqueles que ele havia descrito nos anos anteriores e que construíam, ou “objetivavam", para usar uma expressão cara a Veyne, na "tela"—aí trazendo para o nosso presente televisivo-da "verdade", aquilo que seria a vida, o trabalho, a linguagem, a morte e a loucura ${ }^{21}$. O poder, também, é uma objetivação, também é apresentado como algo, uma coisa, que tem uma natureza. E quem cuida de fazer tal objetivação, quem produz tal coisa é, fundamentalmente, o intelectual. O que Foucault vai fazer ao longo dos anos em que se dedicou a pesquisar o poder não se distancia muito, portanto, daquilo que ele fez com relação a outros saberes: é mostrar como não existe de fato uma coisa, o poder; mostrar que o que existe são práticas discursivas que delimitam quem, como, quando e onde se pode dizer "a verdade" do poder. Assim como para os saberes analisados pela arqueologia há regras de enunciação, há uma gramática que é desvendada e que varia— tal qual o giro de um caleidoscópio faz variar

\footnotetext{
${ }^{21}$ Em "Foucault révolutionne l'histoire" (VEYNE, Paul, Comment on écrit l'histoire; Paris, Seuil, 2002, pp. 383-429) Veyne utiliza o exemplo do circo romano, que ele havia analisado em um livro anterior seu - de maneira que ele ora reconhece errada — para explicar, inspirado na forma como um outro historiador-Georges Ville-analisa o fenômeno do desaparecimento da gladiatura com o advento do cristianismo, o que é e como é o método/pensamento foucaultiano de escrever a história: "Temos o costume, de fato, de raciocinar em função de um alvo ou a partir de uma matéria. Por exemplo, eu acreditei e escrevi, erroneamente, que o pão e o circo tinham por objetivo estabelecer uma relação entre governantes e governados ou respondiam ao desafio que eram os governados. Mas se os governados são sempre os mesmos, se eles têm os reflexos naturais de todo governado, se eles têm naturalmente necessidade de pão e circo, ou de se fazer despolitizar, ou de se sentir amados pelo amo, por que é que eles só receberam pão, circo e amor em Roma? É necessário, portanto, inverter os termos do enunciado: para que os governados sejam somente percebidos pelo amo como objetos a despolitizar, amar ou levar ao circo, é necessário que eles tenham sido objetivados como povo-rebanho; para que o mestre seja percebido como somente se tornando popular perante o seu rebanho, é necessário que ele tenha sido objetivado como guia muito mais que como ou rei-pai ou rei-sacerdote. São essa objetivações, correlatas de uma certa prática, que explicam o pão e o circo, que jamais chegaremos a explicar partindo dos governados eternos, dos governantes eternos e da relação eterna de obediência ou de despolitização que os une; pois essas chaves entram em todas as fechaduras." (p. 395)
} 
as figuras que vemos no seu interior-ao longo dos séculos, para as instituições, investidas, por definição, de poder, Foucault vai mostrar como, igualmente, existem regras, existe uma gramática que estabelece aquilo que pode e aquilo que não pode, o que é e o que não é plausível, o que é um poder que está de acordo com a sua "verdadeira natureza" e o que é um poder que a perverte, a desvia. Os guardiães dessas regras são os intelectuais.

Um texto fundamental sobre essa relação é, sem dúvida, "Os intelectuais e o poder", conversa entre Foucault e Deleuze, que data de 1972. Ela começa com uma reflexão sobre o que diferencia o envolvimento político de ambos em relação àquele dos intelectuais de partido ou próximos a eles (caso dos maoístas ou de um Sartre): a relação nova entre teoria e prática, diz Deleuze, menos totalizante, mais parcial e fragmentária-“"nenhuma teoria se desenvolve sem encontrar uma espécie de muro, e é necessária a prática para perfurar o muro"22 - com ambas situadas no domínio da ação e não no da representação, onde, precisamente, atuariam os intelectuais que se concebem como consciência "representante ou representativa". Foucault, de sua parte, aprofunda, chamando a atenção para a dupla existência histórica desse tipo de intelectual—de resto, o mais comum—, seja como "maldito", seja como desvelador de relações políticas insólitas ("socialista"): "consciência e eloqüência". Mas, diz Foucault,

"o que os intelectuais têm descoberto a partir da evolução recente, é que as massas não têm necessidade deles para saber; elas sabem perfeitamente, claramente, muito melhor que eles; e elas o dizem muito bem. Mas existe um sistema de poder que barra, interdita, invalida esse discurso e esse saber. Poder que não está somente nas instâncias superiores da censura, mas que se imiscui muito profundamente, muito sutilmente em toda a rede da

\footnotetext{
${ }^{22}$ FOUCAULT, Michel; "Les intellectuels et le pouvoir", in $D E I$, texto no 106, p. 1175.
} 
sociedade. Eles mesmos, intelectuais, fazem parte desse sistema de poder, a idéia de que eles são os agentes da "consciência' e do discurso faz parte ela mesma desse sistema."23

Os intelectuais, "consciências e eloqüências" seriam os veículos para o inconsciente, são quem teria o papel de, como diz Deleuze, "opor uma representatividade a uma falsa representatividade do poder", desvelando, assim, uma verdade totalizante e profunda, reivindicadora de reformas. Mas para ambos esses pensadores isso é uma forma de esconder como é exercido o poder, é uma forma de ilusão, uma hipocrisia; é então que Foucault declara:

"Cada luta se desenvolve em torno de um foco particular de poder (um desses inumeráveis pequenos focos que podem ser um chefete, um vigia de um H.L.M., um diretor de prisão, um juiz, um responsável sindical, um redator-chefe de um jornal). E se nomear esses focos, denunciá-los, falar deles publicamente é uma luta, não é porque ninguém tivesse ainda consciência sobre eles mas porque tomar a palavra a respeito desses temas, forçar a rede de informação institucional, nomear, dizer quem fez o quê, apontar o alvo, é uma primeira afronta ao poder, é um primeiro passo para outras lutas contra o poder. Se discursos como esses, por exemplo, dos internos ou dos médicos de prisões são lutas, é porque eles confiscam ao menos por um instante o poder de falar sobre a prisão, atualmente ocupado exclusivamente pela administração e os seus compadres reformadores. O discurso de luta não se opõe ao inconsciente, ele se opõe ao segredo. Isso tem cara de ser muito menos. E se fosse muito mais? Há toda uma série de equívocos a respeito do 'escondido', do recalcado', do 'não-dito', que permitem 'psicanalisar' a baixo custo aquilo que deve ser o objeto de uma luta. O segredo é possivelmente mais difícil de desvendar do que o inconsciente." 24

O segredo, uma categoria que é da ordem daquilo que, como o inconsciente, necessita vir à tona, mas que, diferentemente daquele, possui uma intencionalidade: é o que deve ser mantido restrito a poucos, porque, caso seja tornado público, há risco de que não mais se acredite em algo que vem sendo dito, risco de descrédito. O inconsciente é o que não se sabe, ou o que pode vir a se saber somente por meio de um grande esforço, o dos intelectuais. O segredo é o que é sabido ou pode facilmente sê-lo, mas não deve ser comunicado.

\footnotetext{
${ }^{23}$ Idem, p. 1176

${ }^{24}$ Idem, p. 1181.
} 
Está aí, possivelmente, a raiz de toda uma forma de proceder, por parte de Foucault, que tendeu a afastá-lo de uma identificação com a concepção de si mesmo como filósofo profissional e a empurrá-lo rumo a um outro meio, o meio jornalístico. Prova disso está na iniciativa que o conduziu a trabalhar como correspondente do jornal italiano Corriere della sera na cobertura daquilo que acabou sendo conhecido como a Revolução Iraniana, que depôs, em 1979, uma dinastia quase centenária nesse país do Oriente Médio. Tal cobertura fez parte de uma série de reportagens à qual foi dada o nome de "reportagens de idéias"—uma iniciativa que envolveu outros pensadores e que acabou resultando em somente três coberturas, dentre as quais essa de Foucault. No texto em que faz a apresentação da publicação de uma dessas reportagens — a de Alain Finkielkraut, sobre os EUA—, Foucault diz:

\begin{abstract}
"há mais idéias sobre a terra do que normalmente imaginam os intelectuais. E essas idéias são mais ativas, mais fortes, mais resistentes e mais apaixonadas do que podem sobre elas pensar os políticos. É necessário assistir ao nascimento de idéias e à explosão de sua força: e isso não nos livros que as enunciam, mas nos acontecimentos nos quais elas manifestam sua força, nas lutas que se levam a cabo pelas idéias, contra ou a favor delas. (...) Não são as idéias que movem o mundo. Mas é justamente porque o mundo tem idéias (e porque ele as produz muito continuamente) que ele não é conduzido passivamente segundo aqueles que o dirigem ou aqueles que gostariam de ensiná-lo a pensar uma vez por todas. ${ }^{25}$
\end{abstract}

Mais do que revelar uma verdade escondida, portanto, uma verdade ainda não percebida, oculta para todos, trata-se de comunicar, de fazer chegar a informação sobre aquilo que já está no mundo, de que essa informação circule para que mais gente—as massas, todos-possa julgar e decidir. A quem cabe realizar esta última tarefa, portanto, é algo que não muda no pensamento de Foucault ao longo dos anos; em 1978, ele continua pensando como em 1972: não é uma prerrogativa dos intelectuais: eles não decidem melhor do que qualquer outro elemento da massa, ou melhor, eles decidem pior do que esses elementos em conjunto, pois estes sabem, ou são capazes de saber,

\footnotetext{
${ }^{25}$ FOUCAULT, Michel; “Les 'reportages' d'idées”, in DE II, texto n 250 , p. 707.
} 
caso estejam informados, "perfeitamente, claramente e muito melhor". A manutenção do segredo sobre o que acontece no mundo é um elemento vital para a manutenção desse outro e último segredo. Um segredo reforça o outro e eis que temos um sistema.

Ao todo, Foucault escreveu onze artigos para o Corriere della sera e participou de uma entrevista para dois jornalistas de um outro hebdomadário, a respeito dos acontecimentos por ele vividos nas suas duas estadias nesse país ora em convulsão. No segundo desses artigos, tem-se uma dimensão do funcionamento desse "sistema de poder" em que os intelectuais do ocidente têm um papel importante. Foucault narra que, antes de embarcar para o Irã, em setembro de 1978, foi-lhe dito inúmeras vezes que esse país enfrentava "uma crise de modernização", com um xá que "mantém os olhos fixos no ano 2000" e uma sociedade tradicional que "em nome de crenças milenares, clama a proteção de um sacerdócio retrógado". "Quantas vezes escutei bons analistas se perguntarem seriamente que forma política poderia no futuro reconciliar o Irã profundo com a sua necessária modernização: uma monarquia liberal, um sistema parlamentar, um presidencialismo turbinado?", diz Foucault. ${ }^{26}$ Alguns dias teriam lhe bastado para perceber que esse dilema entre modernidade e arcaísmo estava, de fato, invertido. O regime "modernizante" do xá Pahlevi, passa a entender Foucault, é que de fato é o arcaísmo: "sim, a modernização como projeto político de transformação social é, no Irã, uma coisa do passado." Esse regime vinha há tempos implantando a modernização desse país, até o ponto em que o seu povo se cansou, não agüentou mais as consequiências pérfidas de tal processo, que, além de carregar consigo a corrupção governamental, provocou, com a reforma agrária mal feita, a emigração às grandes cidades, com a criação de um mercado interno, o benefício dos produtos estrangeiros,

\footnotetext{
${ }^{26}$ FOUCAULT, Michel; "Le chah a cent ans de retard", DE II, texto nº 243, p. 679.
} 
com a adoção de formas atuais de urbanização, o fim do comércio de bazar, com a abertura para o investimento em rendas financeira $\mathrm{e}$ imobiliária, o fim do desenvolvimento industrial nacional. As forças tidas no ocidente como arcaicas, na verdade eram as forças, corajosas, que estavam dando um basta à série de transformações que vinham acontecendo sob a dinastia quase centenária dos Pahlevi e que só haviam piorado as condições de vida da população como um todo ${ }^{27}$.

"Com a agonia atual do regime iraniano, hoje assistimos aos últimos momentos de um episódio que se abriu há aproximadamente sessenta anos: uma tentativa de modernizar à européia os países islâmicos. O xá a ela se apega como à sua única razão de ser. Eu não sei se ele lança seu olhar já rumo ao ano 2000. Mas o seu famoso olhar, eu sei que ele data dos anos '20." 28

Enquanto os intelectuais ocidentais chamavam a atenção para o não-sabido (“que forma política poderia reconciliar o Irã", resolver esse impasse entre o "velho" e o “novo"?), para o desconhecido que se apresenta em pletora de possíveis "soluções", Foucault mostra que o desconhecido mesmo, o que não se mostra, é a própria realidade, é esse "episódio" iniciado há sessenta anos—já velho, portanto—e é a capacidade de um povo de se levantar contra esses elementos que não é verdade que estejam presentes só nessa república hoje islâmica; que são elementos que estão no mundo todo e que receberiam, hoje, possivelmente, o nome de globalização-uma novidade e tanto, portanto, daí o entusiasmo de Foucault com esse processo ${ }^{29}$. Informar o maior número

\footnotetext{
${ }^{27}$ Por ocasião da sua segunda estada em Teerã, em novembro de 1978, Foucault surpreende-se com a rapidez com que o movimento de oposição ao regime tinha avançado na consecução do seu objetivo. O movimento adquire o caráter surpreendente de um maremoto "sem aparelho militar, sem vanguarda e sem partido": "após dez meses a população se opõe a um regime que está entre os mais bem armados do mundo e a uma polícia que está entre as mais temidas. Tudo isso com as próprias mãos, sem recurso à luta armada, com uma obstinação e uma coragem que imobilizam o exército a postos: pouco a pouco ele se congela e hesita em atirar. Há dois meses, ele fazia de três a quatro mil mortos em volta da praça Djaleh; ontem, duzentas mil pessoas desfilaram diante dos soldados que não se mexeram. O governa está nisso reduzido a lançar comandos de provocadores: eles não têm efeito nenhum. Quanto mais a crise decisiva se aproxima, menos o recurso às armas torna-se possível. A sublevação de toda uma sociedade abafou a guerra civil." (FOUCAULT, Michel; "Une révolte à mains nues", in DE II, texto no 248, p. 701) ${ }^{28}$ FOUCAULT, Michel; "Le chah a cent ans de retard", op. cit., p. 681.

${ }^{29}$ Passados trinta anos daRevolução Iraniana e da ascensão do "regime dos Ayatollahs", que avaliação poderíamos fazer desse entusiasmo? Muitos vêem nele um erro, uma ingenuidade no mínimo, dado que o
} 
de pessoas a respeito do que acontece de novo no mundo é uma tarefa grande que é tornada difícil, porque ela mostra precisamente que é mais fácil e mais possível realizar coisas, agir politicamente e mudar a realidade do que dizem os intelectuais, os exemplos já existindo e vindo dos recantos mais "atrasados" e "retrógados" do mundo. Um mundo que já é há muito tempo um único mundo. É “forçar a rede de informação institucional" e confiscar "ao menos por um instante" o poder de falar sobre o assunto política que os intelectuais têm, tal qual os administradores das prisões e seus "compadres reformadores" (acaso, intelectuais também?) o têm de falar sobre o assunto prisão.

Claro está, portanto, que há uma linha da ação que permanece inabalada ao longo desses anos em que Foucault passa a se dedicar ao estudo do poder, uma linha que necessariamente inclui uma crítica ao papel dos intelectuais que se concebem como consciência representante ou representativa: os princípios que norteiam as "reportagens de idéias", de 1978, são fundamentalmente os mesmos que nortearam o Groupe

que se seguiu foi uma série de restrições à liberdade, culminando, em alguns casos, em assassinatos. Hoje, os ânimos, volta e meia, são revoltos, tanto no Ocidente quanto nos países que se alinham ao regime iraniano, por episódios como o das charges publicadas, no início de 2006, por um jornal dinamarquês, fazendo chacota do profeta Maomé; publicação que foi seguida de violentas manifestações em todo o mundo muçulmano, ofendido, e nas comunidades muçulmanas situadas em países ocidentais. Contra essas manifestações, toda uma série de contra-manifestações clamando pelo direito à liberdade de expressão. O que me parece marcar esses dois episódios é a capacidade de se erguer contra algo que é percebido como intolerável e de se sublevar - uma palavra importante, como veremos, no pensamento de Foucault - contra esse estado de coisas, que o islã carrega consigo. O pesquisador francês Olivier Roy é alguém que faz uma boa análise a esse respeito, dizendo, especificamente sobre a Revolução Iraniana que, na verdade, "o problema de Foucault não é tal ideologia ou tal sistema político, mas o poder em si"-que estava sendo, nessa ocasião, "posto a nu". (ROY, Olivier; "L'énigme du soulevement", in Vacarme; Automme 2004, $\mathrm{n}^{\circ}$ 29, p. 36) Essa capacidade, diz esse autor, é algo que o regime que se instaurou em seguida no Irã terá sempre dificuldade em lidar, em "conjurar o vazio que o sagrado instaurou (a partir daí) no centro do poder" (Idem, p. 38); e, assim, não há, como disse Foucault, nada de "inútil" em se sublevar. No caso, mais atual, das "charges", esse mesmo autor chama a atenção para o fato de que "existe um limiar de tolerância muito variável na opinião pública (ocidental). Nenhum grande jornal publicaria caricaturas zombando de cegos, anões, homossexuais ou ciganos, mais por temor ao mau gosto do que por medo de represálias judiciais. Mas o mau gosto é aceito no caso do islã, pois a opinião pública é mais permeável à islamofobia. O que choca o muçulmano médio não é a representação do profeta, mas a existência de dois pesos e duas medidas." (ROY, Olivier "Charges expõe geopolítica da indignação", in Folha de São Paulo, 9 de fevereiro de 2006, p. A 13) 
d'Information des Prisons, fundado por Foucault e outros intelectuais em $1971^{30}$. Mais conhecido por sua sigla, o G.I.P não tinha o propósito de encontrar ou propor soluções para os problemas encontrados nas prisões francesas. Não buscava a reforma das prisões, mas sim, justamente, fazer circular aquilo que está no seu próprio nome: a informação (a respeito das prisões). Não foi a reunião de um grupo de intelectuais incumbidos de encontrar algo, mas antes, muito mais uma espécie de comitê de redação preocupado em que a informação chegasse aos prisioneiros, à população carcerária e àquela à sua volta, aos maiores interessados em que as coisas mudem para melhor, àqueles que podem saber "perfeitamente, claramente e muito melhor". Segundo Foucault, numa entrevista ocorrida em 1979 em que ele assume o pseudônimo de Louis Appert em sinal de protesto contra um diretor da revista onde a entrevista foi publicada, "era um lugar de reunião" onde

\begin{abstract}
"é claro, discutia-se para saber quais eram as providências mais eficazes, mas nenhuma ordem era dada. (...) Era um instrumento de questionamento da prisão e de agitação nas prisões, mas também um meio de inquietar a administração penitenciária e os jornalistas: a prisão, ela não é um lugar imóvel onde nada acontece e do qual sabemos que saem alguns infelizes malandros, é algo no qual acontecimentos ocorrem todos os dias: greves de fome, rejeição da alimentação, tentativas de suicídio, movimentos de revolta, confusões. Toda essa vida convulsiva que literalmente não 'existia', mesmo para aqueles que tinham escrito coisas muito boas sobre as prisões, nós tentamos fazer com que fosse conhecida no seu dia-a-dia. (...) Era preciso fazer a prisão entrar na atualidade, não sob a forma de problema moral, ou de problema de gestão geral, mas como um lugar onde ocorre história, cotidiano, vida, acontecimentos da mesma ordem que uma greve num galpão de fábrica, um movimento de reivindicação num bairro, um protesto público numa localidade H.L.M.." ${ }^{31}$
\end{abstract}

\footnotetext{
${ }^{30}$ Renato Janine Ribeiro, no seu ensaio "O intelectual e seu outro"- $-\mathrm{em}$ que levanta a diferença entre a concepção sartriana e a foucaultiana no que diz respeito ao papel a ser exercido pelo intelectual, ou seja, justamente o ponto a que está se querendo chamar a atenção-lembra também de um outro exemplo dessa linha de ação: aquele que resultou na publicação do livro sobre Pierre Rivière, um matricida/fratricida do século XIX, "que a normalidade considerou louco" e sobre quem Foucault e seus assistentes "em vez de analisá-lo, (...) redigiram textos complementares ao do próprio Rivière. Daí, quando o lemos, uma certa frustração. Mas proposital, porque produzindo-a Foucault rompia exatamente com o modelo que podemos, com alguma perfídia e exagero (mas apenas alguma), denominar sartriano." (RIBEIRO, Renato Janine, "O intelectual e seu outro", in Tempo Social, op. cit, pp. 148-149)

${ }^{31}$ FOUCAULT, Michel; "Luttes autour des prisons", in DE II, texto no 273 , p. 809.
} 
E assim como no caso do Irã, a recusa em adotar respostas prontas e "de fora" é a grande tônica do trabalho desse grupo, que, segundo um dos seus integrantes, JeanMarie Domenach, foi “a experiência mais reconfortante (por ele vivida) desde a Resistência",32 — e que teve o seu fim em 1974, quando o trabalho que realizou e vinha realizando foi assumido pelos próprios internos na figura do Comité d'action des prisonniers (C.A.P.). Nisso, não deixou de causar tremendo incômodo no meio dos intelectuais e dos partidos políticos: como era possível uma ação política que nada propusesse? Foucault narra em pelo menos duas ocasiões como a reação de uma das instâncias do P.C.F. foi a de propor publicamente que os seus integrantes fossem presos (sob suspeita de estarem colaborando com a polícia)! ${ }^{33}$ Na entrevista de 1979 , reafirma o princípio da recusa a profetizar, a adotar essa atitude de ser uma consciência que rompe o diálogo (com a administração, no caso), tornando-se "maldita", quando não se vê atendida:

"o problema (do Groupe) não era dizer: tal e tal coisa não dá, e conseqüentemente eis quais as condições sob as quais elas dariam, era simplesmente o de dizer: eis aí um problema, eis aí algo que não é tolerado pelas pessoas e que não é tolerável. A idéia de que um movimento de crítica, ao mesmo tempo muito fortemente ligado a uma prática, não tenha que se obrigar a ser um movimento de reforma ou a ser uma instância de proposição de reforma, é algo que sempre defendemos. (...) Eu creio que nós não tínhamos de todo a impressão de nos furtar dizendo: nós não temos nada a propor, no sentido de que não cabe a nós propormos; eu creio que não era ilógico, que não era nem mesmo curto demais, pois afinal de contas, não éramos nós que havíamos criado as prisões, não éramos nós que lá trabalhávamos. Nós dizíamos que essa existência das prisões colocava problemas, tanto quanto o que lá dentro acontecia. Nós não queríamos nesse grupo nenhuma prescrição, nenhuma receita, nenhuma profecia." ${ }^{34}$

Transpondo, por nossa conta, essas palavras para o Irã, diríamos na voz de Foucault: "nós não somos iranianos", "não cabe a nós propormos nada a respeito", o que não nos impede de sermos solidários ou, até mesmo, querermos sê-lo (iranianos) e querermos mostrar ao mundo, com admiração, o que é sê-lo, ou o que foi sê-lo num determinado

${ }^{32}$ FOUCAULT, Michel; "Toujours les prisons", in DE II, texto $\mathrm{n}^{\circ} 282$, p. 916.

${ }^{33}$ FOUCAULT, Michel; "Luttes autour des prisons", op. cit. p. 807 e "Entetien avec Michel Foucault", in DE II, texto n' 281, pp. 904-905.

${ }^{34}$ FOUCAULT, Michel; "Luttes autour...”, op. cit., p. 813. 
momento. Como diz Deleuze, já em 1972, a Foucault em "Os intelectuais e o poder": "na minha opinião, você foi o primeiro a nos ensinar algo de fundamental, ao mesmo tempo nos seus livros e num domínio prático: a indignidade de falar pelos outros."35

\subsubsection{Prisão e Estado moderno}

O G.I.P. é o exemplo de uma intervenção bem sucedida que se insere num amplo espectro de outras intervenções realizadas por Foucault ao longo dos anos '70. É talvez a mais importante, a mais longa e a mais fecunda. Dela, surgiu um dos principais livros desse autor, Vigiar e punir, cujo subtítulo é Nascimento da prisão. O que vem a ser esse livro, a que necessidade ele responde? É um livro, do mesmo modo que a ação levada a cabo no G.I.P, dedicado a fazer circular a informação sobre a prisão? Destinase, como os cadernos desse grupo, aos prisioneiros e aos seus familiares, aos administradores das prisões e aos jornalistas primordialmente? Sim, esses são possíveis alvos seus, mas não, não há exclusividade aí: é um livro para todos, é um livro da mais pura filosofia tal como entendida por Foucault, ou seja, uma "maneira de refletir a respeito não do que é verdadeiro e do que é falso, mas sobre a nossa relação com a verdade" ${ }^{36}$. A prisão, o sistema prisional enquanto instituição, é algo que surge e se

\footnotetext{
${ }^{35}$ FOUCAULT, Michel; "Les intellectuels et le pouvoir", op. cit., p. 1177.

${ }^{36}$ FOUCAULT, Michel; "Le philosophe masqué", op. cit.,, p. 929. "É, em certo sentido, um livro de pura história", diz Foucault na entrevista que concedeu a Ducio Trombadori em 1978—e isso não lhe tira nada da sua condição filosófica, diga-se de passagem, já que, como mostra Veyne, Foucault é o primeiro historiador verdadeiramente positivista, ou seja, a praticar um outro tipo, revolucionário, de história, que irá justamente inserir a produção da verdade, a objetivação, naquilo que lhe cabe historiar-, "mas as
} 
prolonga, com sucesso, ao longo de uma história que, feito as outras histórias que ele já havia escrito, traziam uma "verdade" no seu cerne, anunciavam-na, dela não se separavam. Essa história é a história do Estado moderno. É o poder que passa a ser o objeto de estudo de Foucault nos anos '70, o poder não naquilo que ele apresenta de si como natureza, como coisa, mas como produção que diz possuir uma verdade, que é marcada pelo conhecimento; e o Estado é esse dizer, ou um desses dizeres. Poderíamos dizer: continuamos trabalhando com discursos? Em um sentido bastante amplo, sim, não se deixa nunca de trabalhar com eles. Mas, assim como na arqueologia do saber Foucault não partiu para a tentativa de definir "o" saber e mostrar o que ele é-a não ser retrospectivamente-mas de mostrar o seu funcionamento em pontos específicos, agora, com o Estado, tampouco se trata de entendê-lo a não ser pelo seu funcionamento real e não teórico.

Em Vigiar e punir, Foucault vai mostrar que o poder não é coisa, mas sim exercício-daí a própria forma, verbal, do título, vigiar, punir — e que se ligação ele tem com a verdade, essa ligação é o próprio exercício do poder na modernidade; eis o que mostra a série de conferências intituladas "A verdade e as formas jurídicas", uma espécie de prolegômeno a Vigiar e punir: que a forma jurídica que se baseia no inquérito-uma prática, "um mecanismo" ou "maneira singular de produzir a verdade" 37 , que Foucault data da Grécia clássica e que ele mostra ter um dos seus primeiros retratos na tragédia Édipo-rei, de Sófocles-é algo que surge como forma predominante de resolução de litígios num determinado momento da história do Ocidente—fim da Idade Média— e que essa forma não corresponde necessariamente a

pessoas que dele gostaram, ou detestaram, o fizeram porque tinham a impressão que era delas mesmas que se tratava ou do mundo meramente contemporâneo, ou das suas relações com o mundo contemporâneo, na forma como esse é aceito por todos." ("Entretien avec Michel Foucault", op. cit., p. 866)

${ }^{37}$ FOUCAULT, Michel; A verdade e as formas jurídicas, op. cit. p. 32. 
um avanço no conhecimento, mas sim, a uma que os poderosos de então encontraram para fixar a sua autoridade ${ }^{38}$. É uma forma de saber-poder, que, no entanto, se apresenta somente como um saber, como uma necessidade: é onde e como há justiça, mais justiça; é onde e como um poder instituído, o Estado, é exercido. É um procedimento que carrega consigo tal poder que consegue até mesmo derrubar um rei da magnitude de Édipo, aquele que tinha salvado os tebanos da grande praga da Esfinge-e que o destino quis que fosse o assassino involuntário de seu próprio pai, Laio, o antigo rei.

A conexão poder-justiça, a viabilização de um poder mais "justo", por meio do inquérito e da descoberta da verdade, eis aí uma das condições sob as quais se estabelecem os intelectuais de tipo universal. Numa rica entrevista concedida em 1976 a Pasquale Pasquino ${ }^{39}$, Foucault fala a respeito:

"Podemos supor que o intelectual universal tal como ele funcionou no século XIX e começo do século XX é de fato derivado de uma figura histórica bem particular: o homem de justiça, o homem de lei, aquele que, ao poder, ao despotismo, ao abuso, à arrogância da riqueza, opõe a universalidade da justiça e a eqüidade de uma lei ideal. As grandes lutas políticas do século XVIII fizeram-se em torno da lei, do direito, da Constituição, daquilo que é justo por razão e por natureza, daquilo que pode e deve valer universalmente. Aquilo que hoje chamamos de intelectual (quero dizer o intelectual no sentido político, e não sociológico ou profissional da palavra, isto é, aquele que faz uso do seu saber, da sua competência, da sua relação para com a verdade no âmbito das lutas políticas) nasceu, creio eu, do jurista, ou em todo caso do homem que reividicava para si a universalidade da lei justa, eventualmente contra os profissionais do direito (Voltaire é, na França, o protótipo desses intelectuais). O intelectual universal deriva do juristanotável e encontra a sua expressão maior no escritor, portador de significações e de valores nos quais todos podem se reconhecer." 40

É uma nobre derivação. E, de fato, nessa história da prisão que é Vigiar e punir, lê-se até mesmo uma pequena ponta daquilo que poderia ser uma simpatia para com o "lirismo" contido no "grito do coração" que os teóricos reformadores do direito penal

38 "Não foi racionalizando os procedimentos judiciários que se chegou ao procedimento do inquérito. Foi toda uma transformação política, uma nova estrutura política que tornou não só possível, mas necessária a utilização desse procedimento no domínio judiciário. O inquérito na Europa Medieval é sobretudo um processo de governo, uma técnica de administração, uma modalidade de gestão; em outras palavra, o inquérito é uma determinada maneira do poder se exercer. Estaríamos enganados se víssemos no inquérito o resultado natural de uma razão que atua sobre si mesma, se elabora, faz seus próprios progressos, se víssemos o efeito de um conhecimento se elaborando”, diz Foucault. (Idem, p. 73)

${ }^{39}$ FOUCAULT, Michel; "Entretien avec Michel Foucault", in DE II, texto n' 192, pp. 140-160.

${ }^{40}$ Idem, p. 156. 
do final do século XVIII, tais como Beccaria, antepunham, num prenúncio daquilo que viria a ser o discurso dos direitos humanos, aos horrores da principal forma de punir até então vigente: o intolerável suplício. Diz Foucault a esse respeito: "tudo se passa como se o século XVIII tivesse aberto a crise dessa economia (dos castigos), proposto para resolvê-la a lei fundamental de que o castigo deve ter a 'humanidade' por 'medida', sem que um sentido definitivo tenha podido ser dado a esse princípio considerado, entretanto, como incontornável."41 Mas a ponta de simpatia não passa disso, como é mostrado na seqüência.

Esses reformadores não são os pais do atual sistema prisional. (Este, como mostra Foucault, passa a vigorar no Ocidente no começo do século XIX, a partir da Europa bem como dos Estados Unidos da América, estendendo-se até os dias atuais, como a forma preponderante e praticamente exclusiva do ato de punir). Contudo, a segunda parte de Vigiar e punir, intitulada "Punição", mostra a importância que esses teóricos do direito tiveram no caminho que conduz a esse estado de coisas. O clamor que eles materializaram por um abrandamento das punições às quais eram submetidos os criminosos no Antigo Regime-punições essas nas quais o soberano aparecia como o agente que mostrava a todos o espetáculo da sua vingança-, o "humanismo" dessa "nova penalidade" contida nos seus tratados e nas suas intervenções legislativas, diz Foucault, não passou de "uma tendência (...) rumo a um esquadrinhamento penal mais cerrado do corpo social" 42 , de uma forma de "estabelecer uma nova 'economia' do poder de castigar, de lhe assegurar uma melhor distribuição, de fazer com que ele não se concentre demais em alguns pontos privilegiados, nem seja compartilhado demais entre

\footnotetext{
${ }^{41}$ FOUCAULT, Michel; Surveiller et punir ; Paris, Gallimard, 2004, p. 89.

${ }^{42}$ Idem, p. 93.
} 
instâncias que se opõem."43 Foucault explica: o poder do monarca que era expresso nos suplícios, esse poder era, nas sociedades do Antigo Regime, pareado, fazia uma dupla com toda uma série de ilegalismos, por parte da população, que eram, de um modo geral, tolerados, constituíam, em muitos casos, privilégios estabelecidos e caracterizavam uma justiça “irregular”. Os reformadores do direito penal vieram para acabar com isso, para "reestruturar a economia" desses ilegalismos, para "redistribuílos":

“em Le Trosne, como em tantos outros à mesma época, a luta pela delimitação do poder de punir se articula diretamente à exigência de submeter o ilegalismo popular a um controle mais estrito e mais constante. Compreende-se que a crítica dos suplícios tenha tido uma importância tal na reforma penal, pois era a figura aonde vinham se reencontrar, de forma visível, o poder ilimitado do soberano e o ilegalismo sempre a postos do povo. A humanidade das penas, é a regra que se dá a um regime de punições que deve fixar os limites aos quais um e outro devem se ater. O 'homem' que se quer fazer respeitar na pena é a forma jurídica e moral que se dá a essa dupla delimitação." ${ }^{44}$

Nisso, esses reformadores atendiam às exigências de uma nova economia, baseada nas mercadorias e na sua circulação por meio do mercado. Uma economia, a capitalista, que não poderia tolerar o costume das pequenas infrações, dos pequenos roubos, isso ao que Foucault dá o nome de "ilegalismo de bens" e que veio a ser separado de um "ilegalismo de direitos" (ao qual estava anteriormente ligado, num momento em que ambos eram uma "condição do funcionamento político e econômico da sociedade" ${ }^{45}$ )— ficando este último, inclusive, como chama a atenção Foucault, reservado à pura burguesia, à dona dos bens. Esse movimento de redistribuição dos ilegalismos, por sua vez, casou-se muito bem com uma cisão que estava em forte sintonia com a teoria do contrato social: a separação entre aqueles cidadãos de bem que respeitam as leis e aqueles, "traidores", que não as respeitam, os "inimigos da sociedade", seres que adquirem a estatura de "monstros". Essa transformação, Foucault a expressa de forma

\footnotetext{
${ }^{43}$ Idem, p. 96.

${ }^{44}$ Idem, p. 105.

${ }^{45}$ Idem, p. 98.
} 
cristalina quando diz que se passou a defender e praticar que a lei deve agora "tratar 'humanamente' aqueles que são 'fora-da-natureza'”, ao passo que a justiça de outrora consistia em "tratar de forma desumana aqueles que estavam 'fora-da-lei'.,46

As propostas desses humanistas apontavam, portanto, para uma generalização da punição. A concepção que eles tinham a respeito da forma de punir, uma vez efetivada essa reestruturação da economia dos ilegalismos, contudo, não passava pela prisão; era diferente: baseava-se na idéia de uma "cidade-punitiva". Esse modelo fazia uso do ato de punir, que necessariamente passa pelo corpo, na constituição de todo um jogo de representações que deveriam estar sempre presentes nas mentes dos cidadãos, uma espécie de campanha publicitária permanente que deveria provocar nesses sujeitos o constante cálculo a respeito dos prós e contras do crime, dos seus benefícios possíveis, mas também dos seus custos, que sempre deveriam ser maiores. As penas dentro desse modelo- - em geral, o trabalho forçado, o banimento, a reparação e a manifestação de arrependimento-, deveriam ser sempre públicas e aqueles que se encontrassem a elas sujeitos deveriam receber os cidadãos e seus filhos, assim como os museus recebem visitantes diversos-Foucault fala em "museu da ordem" quando se refere à ocasião e local da aplicação das penas ${ }^{47}$. A prisão consiste numa forma outra de aplicação da pena, que se utiliza da disciplina e atua diretamente nos corpos dos criminosos. São formas diversas, portanto, soluções até certo ponto divergentes: a cidade-punitiva e a prisão, a "instituição-punitiva". A história mostrou que a segunda frutificou, mas as bases comuns estavam já dadas. Ambas essas soluções, mostra Foucault, têm em comum a concepção de que o objetivo da punição é a prevenção, o exemplo que irá evitar que outros queiram imitar aqueles que ora estão sendo castigados pelos seus

\footnotetext{
${ }^{46}$ Idem, p. 109.

${ }^{47}$ Idem, p. 132.
} 
crimes. A individualização das penas, também: "na sua duração, sua natureza, sua intensidade, a maneira como ele é cumprido, o castigo deve ser ajustado ao caráter individual, e àquilo que ele carrega consigo de perigo para os outros." ${ }^{48}$ É assim que não há incompatibilidade, ainda que alguns dos princípios defendidos pelos reformadores, notavelmente o da publicidade ${ }^{49}$, sejam feridos de morte pela forma prisional de punir. Como chama à atenção o autor, não só na França pós-Revolução, mas ao longo de toda a Europa, passa-se a adotar novos códigos penais baseados nas idéias desses reformadores, códigos onde "a diversidade (das penas), tão solenemente prometida, se reduz finalmente a essa penalidade uniforme e cinzenta" que é a prisão ${ }^{50}$. O solo sobre o qual se dão essas duas soluções é um solo comum: "lá onde se faz a diferença (...) é na tecnologia da pena, não no seu fundamento teórico, na relação que ela estabelece com o corpo e a alma, e não na maneira pela qual ela se insere no interior do sistema do direito." 51

Em torno da prisão, em cujo interior se desenvolve todo um saber-o saber disciplinar, baseado na técnica do exame e na tecnologia panóptica—que Vigiar e punir, na sua terceira parte, vai mostrar o que é e como veio a se tornar a moeda corrente de uma série de outras instituições das sociedades modernas—a escola, a fábrica, o quartel, o hospital—configurando aquilo a que Foucault dá o nome de "sociedades disciplinares", em torno dessa instituição-mãe, os reformadores do século XVIII vão

\footnotetext{
${ }^{48}$ Idem, p. 151.

${ }^{49}$ As relações que se instauram entre quem pune e quem é punido, dentro de uma prisão, diz Foucault, são bem diferentes daquelas que entre essas duas figuras se instauram quando a punição é realizada fora: é uma "relação que não somente torna inútil a dimensão do espetáculo: ela o exclui. O agente de punição deve exercer um poder total, que nenhuma terceira parte deve vir perturbar; o indivíduo a ser corrigido deve ser inteiramente envolto pelo poder que se exerce sobre ele. Imperativo do segredo" (Idem, p. 153), o que nos remete à questão, levantada acima, que se encontra em "Os intelectuais e o poder" e na entrevista em que Foucault responde a perguntas sobre o G.I.P. e à sua função de acompanhar a vida convulsiva das prisões no seu dia-a-dia.

${ }^{50}$ Idem, p. 137.

${ }^{51}$ Idem, p. 151.
} 
haver construído todo um arcabouço, o arcabouço jurídico que dá sustentação ao Estado moderno, que vai delimitar um campo discursivo que não permitirá mais que qualquer um fale sobre a relação governante-governado a não ser que dentro de determinados parâmetros, a não ser que dentro de uma "verdade" sobre essa relação, materializada pelo Estado-de-Direito. Fica clara, portanto, toda a série de advertências feitas a Foucault antes da sua viagem ao Irã: há uma crise de "modernização", dizem-lhe; e essa crise é, na verdade, uma crise de um Estado-de-Direito. O Irã, com a sua Revolução, representou uma possibilidade que foi logo detectada por Foucault e que talvez o tenha marcado de forma profunda e sido decisiva para confirmar a inflexão que iria a dar, a partir de 1978, à sua compreensão do fenômeno do poder: a possibilidade de uma nova relação entre governantes e governados, uma relação que não passasse pela necessidade do "discurso verdadeiro" do Estado-de-Direito ${ }^{52}$. Vigiar e punir, portanto, não é somente um livro sobre a prisão: ele é um livro sobre o poder, sobre como se estabeleceu, num determinado momento—final do século XVIII—, uma série de regras

52 Essa preocupação com o discurso verdadeiro do Estado vai ser o grande tema dos dois cursos cujas degravações saíram há pouco, Sécurité, territoire, population, de 1978 e Naissance de la biopolitique, de 1979. No primeiro, como veremos mais adiante, a verdade sobre o Estado vai aparecer sob a doutrina da Razão de Estado, que vigeu na Europa entre os séculos XVII e XVIII. No segundo, ela aparece na forma de um mercado e de uma sociedade que configuram a doutrina liberal e neo-liberal. Foucault, como veremos igualmente, chama esses dois de episódios de uma mesma história mais antiga: a do "poder pastoral", ou "governametalidade", conceitos-chaves que ele inventa nesse ano de 1978 . Sobre a possibilidade de uma nova relação entre governantes e governados, em dois dos artigos sobre o Irã escritos depois do seu encontro com um dos líderes máximos do xiitismo e da Revolução, o ayatolá Chariat Madari (que nos primeiros momentos após a deposição se desentenderia com o ayatolá Khomeini e acabaria sendo relegado do poder), "Tehéran: la foi contre le chah" e "À quoi rêvent les Iraniens", Foucault analisa o papel dos mulás e dos ayatolás em relação à população que os segue para dizer que ele se baseia num "jogo da palavra e da escuta", onde esse outro elemento apresenta uma "solicitação incessante": a de que eles, os clérigos, denunciem a justiça, critiquem a administração, se ergam contra as medidas inaceitáveis, bradem e prescrevam pois, "esses homens de religião são semelhantes a placas sensíveis onde se gravam as queixas e as aspirações da comunidade." (FOUCAULT, Michel; "Tehéran: la foi contre le chah", in $D E I I$, texto n ${ }^{\circ} 244$, p. 687). Ou, então, para dizer que esses homens têm um "papel ao mesmo tempo de eco e de guia", o que viria a "dar à vontade de 'governo islâmico', uma coloração particular." (FOUCAULT, Michel; "À quoi rêvent les iraniens", in DE II, texto no 245, p. 691). Assim, fecha o primeiro desses artigos Foucault com as seguintes palavras: "Espantoso o destino da Pérsia. Na aurora da história, ela inventou o Estado e a administração: ela confiou as suas receitas ao Islã e seus administradores serviram de quadros ao Império Árabe. Mas desse mesmo Islã ela fez derivar uma religião que não tem cessado, através dos séculos, de dar uma força irredutível a tudo aquilo que, do fundo de um povo, pode se opor ao poder de Estado." (FOUCAULT, Michel; "Tehéran:...", op. cit. p.688) 
para poder se falar a respeito do poder com "propriedade", com "conseqüência", "sem desvario", dentro dos parâmetros de um "saber verdadeiro". E de como esse arcabouço, tão "nobre" nos seus propósitos igualitários e humanizantes, não se perturbou no mínimo com a existência de uma instituição, localizada no centro da sociedade sobre a qual ela diz a sua "verdade", dita os seus princípios inarredáveis, de uma instituição que funciona, como diz Foucault, ao seu arrepio ${ }^{53}$. Isso é fácil de entender, desde o momento em que a sensibilidade que é manifesta no "grito do coração" que subjaz à reivindicação do abrandamento das penas por parte desses reformadores do sistema penal do final do século XVIII é a sensibilidade do "homem razoável que faz a lei e não comete o crime" e que

"o corpo, a imaginação, o sofrimento, o coração a respeitar não são, em efeito, aqueles do criminoso que se deve punir, mas a dos homens que, tendo subscrito o pacto, têm o direito de exercer contra ele o poder de se unir. Os sofrimentos que o abrandamento das penas deve excluir são aqueles dos juízes e dos espectadores com tudo aquilo que eles podem acarretar de endurecimento, de ferocidade induzida pela familiaridade, ou ao contrário de piedade induzida, de indulgência pouco fundada: 'Graça para essas almas doces e sensíveis sobre as quais esses horríveis suplícios exercem uma espécie de tortura.' O que é preciso dosar e calcular, são os efeitos de refluxo do castigo sobre a instância que pune e o poder que ela pretende exercer., ${ }^{, 54}$

A prática de falar pelos outros mostra, nesse livro, todos os seus efeitos nocivos, todos os seus resultados deletérios, toda a sua indignidade, todo o seu vínculo a um sistema de poder, a um exercício que não permite que uma outra fala surja, uma fala capaz de encontrar, talvez, um outro exercício, mais perfeito, mais claro e melhor.

\footnotetext{
53 “...enquanto os sistemas jurídicos qualificam os sujeitos de direito, segundo normas universais, as disciplinas caracterizam, classificam, especializam; elas distribuem ao longo de uma escala, repartem em volta de uma norma, hierarquizam os indivíduos uns em relação aos outros e, no limite, desqualificam e invalidam. De todo modo, no espaço e durante o tempo em que exercem o seu controle e efetivam as dessimetrias do seu poder, elas efetuam uma suspensão, jamais total, mas tampouco jamais anulada, do direito. Tão regular e institucional quanto possa ser, a disciplina, no seu mecanismo, é um contra-direito. E se o juridismo universal da sociedade moderna parece fixar os limites ao exercício dos poderes, seu panoptismo ubíquo nela faz funcionar, ao arrepio do direito, uma maquinaria ao mesmo tempo imensa e minúscula que sustenta, reforça, multiplica a dessimetria dos poderes e torna vãos os limites que the foram traçados." (FOUCAULT, Michel; Surveiller et punir ; op. cit. p. 260)

${ }^{54}$ Idem, pp. 108-109.
} 


\subsubsection{Ideologia}

A análise crítica que Foucault faz a respeito do Estado moderno enquanto dizer verdadeiro sobre o poder poderia muito bem ser vista como algo próximo da crítica que um tipo específico-mas bastante comum no período vivido por Foucault-de intelectual, o intelectual marxista, fazia-e continua a fazê-lo, mas não com tanta ênfase, depois da queda do Muro de Berlin—a esse mesmo Estado, que recebia— recebe-, de sua parte, a qualificação pejorativa de "burguês". Sob esse ângulo, Foucault apareceria como um possível marxista, como um marxista dedicado a destrinchar o fenômeno, tão pouco estudado sob essa "luz", do poder. E, de fato, Foucault teve uma militância no Partido Comunista Francês, entre 1950 e 1952. Foi, igualmente, aluno e amigo de Althusser. Mas a crítica ao dizer verdadeiro sobre o poder é, também—e numa medida bastante ampla, ou profunda—uma crítica a essa crítica do marxismo, ou seja, uma crítica ao conceito de ideologia, o qual era-é—o principal meio pelo qual tal crítica era e é realizada.

Um dos principais textos onde pode ser lida a relação que Foucault teve com o marxismo e com os intelectuais que se colocam sob a sua inspiração é a longa entrevista concedida em fins de 1978 a Ducio Trombadori ${ }^{55}$. Nela, Focault narra um pouco da sua

\footnotetext{
55 FOUCAULT, Michel; "Entretien avec Michel Foucault", op. cit., pp. 860-914. Essa entrevista é o resultado, por sua vez, de um entrevero entre Foucault e alguns intelectuais comunistas, membros do PCI, que foi provocado, em grande parte, pela publicação não autorizada de trechos de uma outra entrevista (FOUCAULT, Michel; "Précisions sur le pouvoir. Réponses à certains critiques", in DE II, texto $n^{\circ} 238$ ) dada por ele, num jornal italiano. A entrevista a Trombadori é um esforço de Foucault em por fim à polêmica, por meio de uma ampla discussão "cuja função seria menos a de reduzir as idéias a seus autores, os autores a combatentes e a luta a uma vitória do que multiplicar as hipóteses, os campos, as
} 
experiência como militante do PCF: era o pós-guerra e "a rejeição do mundo na qual nós (quem tinha vinte anos quando a guerra acabou) vivíamos não era seguramente satisfeita pela filosofia hegeliana. Nós estávamos à procura de outras vias para nos conduzir rumo a esse inteiramente outro que nós acreditávamos que fosse encarnado pelo comunismo." Ele então entrou no Partido, para ser "algo de inviável, ou se quisermos, ridículo (...) eu bem o sabia": um "comunista nietzscheano". Saiu dois anos depois, após uma "persistente impressão de mal-estar", quando, após a morte de Stálin, descobriu-se que a notícia que havia sido alardeada, a respeito de um inverossímil complô de médicos judeus para matá-lo—e que havia sido exposta e abonada em reuniões pelos líderes da célula estudantil à qual ele pertencia, e pela qual "esforçou-se" em crer-mostrou-se falsa: "isso também fazia parte desse modo desastroso, essa maneira (nietzscheana) de estar dentro do Partido: o fato de ser obrigado a sustentar algo que era o mais contrário àquilo que se pode acreditar fazia justamente parte desse exercício de dissolução do eu e de procura de um inteiramente outro." ${ }^{56}$ Mas a diferença não pararia por aí, nessa constatação do "lado ridículo da conversão, do ascetismo, da auto-flagelação que é um dos elementos importantes da maneira pela qual muitos estudantes-ainda hoje na França-participam da atividade do Partido Comunista" ${ }^{57}$ : ela ficaria clara na reação silenciosa dos intelectuais comunistas ao seu primeiro livro, à História da loucura; essa reação, no fundo, seria a primeira de uma série de manifestações que iriam desembocar nas acusações a respeito da concepção de poder sustentada por Foucault em Vigiar e punir e em A vontade de saber ${ }^{58}$, por parte de intelectuais do Partido Comunista Italiano-que alegavam que ela legitimaria as

questões, os interlocutores, jogando luz sobre as diferenças que os separam e portanto nas dimensões da busca." (FOUCAULT, Michel; "Lettre de Foucault à L'Unità", in DE II, texto no 254, p. 718)

${ }^{56}$ FOUCAULT, Michel; "Entretien avec Michel Foucault”, op. cit., pp. 869-870.

${ }^{57}$ Idem, p. 870.

${ }^{58}$ Concepção cujos meandros serão explicitados no próximo capítulo. 
ações de grupos terroristas, tais como as das Brigadas Vermelhas, que haviam acabado, em 1978, de seqüestrar e terminariam por matar o ex-primeiro-ministro e líder da democracia cristã italiano Aldo Moro-e que deram origem a essa entrevista. As análises do poder empreendidas por Foucault, dizem essas alegações, ao apontar para o caráter local do seu exercício, impedem qualquer possibilidade de se pensar o coletivo: “é uma questão que me é colocada com freqüência: você ressalta os problemas localizados, mas você não toma jamais posição com relação às escolhas coletivas”, diz ele. ${ }^{59}$ Ao que logo responde:

"É de fato verdade que eu coloco os problemas em termos locais, mas eu creio que isso me permite fazer aparecer problemas que são no mínimo tão gerais quanto aqueles que temos o hábito de considerar estatutariamente como tais. Afinal de contas, a dominação da razão não o é tão geral quanto a dominação da burguesia?"

Seu interlocutor então retruca: "Quando eu falava de visão geral, eu fazia referência essencialmente à dimensão política de um problema e à sua necessária articulação no interior de uma ação e de um programa mais amplo e ao mesmo tempo ligado a certas contingências histórico-políticas.” E Foucault esclarece:

"A generalidade que eu procuro fazer aparecer não é do mesmo tipo que as outras. E
quando me recriminam de só levantar problemas locais, confundem o caráter local de
minhas análises para fazer vir à tona problemas e uma certa generalidade que é levantada
geralmente pelos historiadores, pelos sociólogos, pelos economistas, etc. (...) Os
problemas que eu coloco não são menos gerais que aqueles que habitualmente colocam os
partidos políticos ou as grandes instituições teóricas que definem os grandes problemas
da sociedade. Nunca aconteceu que os partidos comunistas ou socialistas tenham posto,
por exemplo, na ordem do dia de seus trabalhos, a análise do que é o poder da razão sobre
a não-razão. É possível que essa não seja a sua tarefa. Mas, se esse não é o seu
problema, o seu não é não mais forçosamente o meu." 60 Há aí, como ele aponta em outro momento dessa entrevista, uma divergência sobre o modo de se trabalhar com a história, de se "relacionar" com ela, e que também é uma fonte de críticas a seu trabalho da parte de intelectuais marxistas: nem tudo deve se remeter, a fim de encontrar uma explicação, à economia ou à demografia, a um

\footnotetext{
${ }^{59}$ Idem, p. 903.

${ }^{60}$ Idem, p. 904.
} 
fundamento material; e nem só as grandes batalhas fazem a história, são acontecimentos dessa ordem — aquilo que se passa na cabeça das pessoas, bem como o que elas dizem e fazem a partir daí, também o é. Diz Foucault:

"O tipo de inteligibilidade que eu procuro produzir não pode reduzir-se à projeção de uma história, digamos, econômico-social, sobre um fenômeno cultural de modo a fazê-lo aparecer como o produto necessário e extrínseco dessa causa. Não existe necessidade unilateral: o produto cultural faz parte ele também do tecido histórico. Eis a razão pela qual me vejo obrigado a levar a cabo eu mesmo as análises históricas. Fazer-me passar por aquele que nega a história é verdadeiramente divertido. Eu não faço outra coisa que não seja história. Para eles, negar a história, é não utilizar essa história intangível, sagrada e oniexplicativa à qual recorrem. É evidente que, se eu tivesse querido, teria podido citar, nos meus trabalhos, tal ou tal página de um Mathiez ou de um outro historiador. Eu não o fiz porque não pratico o mesmo tipo de análise. Eis tudo. Essa idéia segundo a qual eu recusaria a história provêm menos dos historiadores de carteirinha do que dos meios filosóficos onde não se conhece a fundo o tipo de relação, ao mesmo tempo desapegada e respeitosa, que tal análise histórica requer. Não podendo aceitar uma tal relação com a história, eles daí concluem que eu nego a história."61

Os intelectuais marxistas, seja na sua versão militante, seja na teórica, se opunham, assim como o Foucault de Vigiar e punir, como vimos, ao Estado moderno, ao poder instituído, enquanto verdade sobre o poder. Só que não, como Foucault, para contestar o jogo por meio do qual se faz crer que haja aqueles, os reformadores do direito num primeiro momento, os cientistas políticos e analistas da política e do direito, posteriormente, que conhecem tal "verdade" e que, portanto, "sabem" o que é o mais justo para todos. Os intelectuais marxistas se opunham a esse discurso porque tinham a sua própria "verdade", eram os detentores de um saber verdadeiro, ou melhor, "mais verdadeiro" ou "real" que dizia que a verdade do poder está de fato localizada na esfera material da produção e das relações de produção. Essa seria a chave de compreensão de tudo, da história, e da política, conseqüentemente. Seu pensamento e seu modo de atuar é a atualização de uma "verdade" diferente, com outros "donos", e não um questionamento, como Foucault fazia, do uso, político, do próprio "dizer verdadeiro" a

${ }^{61}$ Idem, p. 896. Sobre a relação que o seu trabalho mantêm com os membros dessas duas profissões, os historiadores e os filósofos, veremos mais adiante um trecho da palestra "Qu'est-ce que la critique", também de 1978, em que esse assunto é abordado de maneira tão esclarecedora quanto aqui, ainda que sob um outro ângulo (cf. infra, nota no 263 ). 
respeito do poder. Assim como os outros intelectuais do Estado-de-Direito, eles se julgavam a consciência universal dos desvalidos, das massas, desse outro ignorante e inconsciente, o proletariado. Por isso, quando Foucault lançou seus estudos e realizou suas intervenções políticas de caráter local, não-propositivo ou profético, passou a receber deles a oposição, sendo chamado, por um Sartre, por exemplo, de "último escudo da burguesia", ou, então, de um negador da história. "Pobre burguesia, diz ele a respeito, se ela não tivesse mais do que a mim como escudo, há muito que já teria perdido o poder!" 62

A crítica marxista ao Estado-de-Direito baseia-se largamente no conceito de ideologia: esta seria uma forma de conhecimento que esconde um desconhecimento. O discurso do Estado-de-Direito é, portanto, tipicamente um discurso ideológico, na medida em que, ao apresentá-lo como o meio mais justo de exercício do poder-o meio mais igualitário, o que faz com que todos sejam transformados paritariamente em cidadãos—, na verdade esconde uma dominação: a dominação da classe detentora dos meios de produção sobre a classe detentora unicamente da força-de-trabalho. Essa crítica diz que essa igualdade é uma ilusão, que há cidadãos "mais cidadãos" que outros. A verdade sobre o poder, portanto, está não no contrato social, no pacto que institui a coisa pública e o exercício de uma soberania, mas na forma de exercício da propriedade dos meios de produção e na dominação de uma classe social sobre a outra, que dela decorre. Foucault, por sua vez, quando inicia suas pesquisas sobre a prisão e sobre o poder, já tem uma noção de que há algo de errado, também, nessa crítica. E o que há de errado $^{63}$ é precisamente a noção de que haja uma verdade, algo, uma "coisa" a ser

\footnotetext{
${ }^{62}$ Idem, p. 881.

${ }^{63} \mathrm{O}$ termo é forte, principalmente para aqueles que acreditam que os tolos são os que erram. Talvez fosse mais apropriado falar em "insuficiência" ou "incapacidade", mas isso implica numa comunhão de direções, o que não parece ser bem o caso. Este, por sinal, está bem retratado numa entrevista de 1984,
} 
conhecida chamada poder. Fica mais clara a impossibilidade de ser um comunista nietzscheano, justamente neste ponto: o marxismo acredita ou faz acreditar na existência de uma verdade sobre o poder, bem como na sua capacidade de conhecer tal verdade e, nisso, conseguir dissolver o poder; já Nietzsche, como lembra Foucault no início das suas conferências já referidas, sobre a verdade e as formas jurídicas, em 1973, acha que o conhecimento foi a grande mentira inventada pelos homens: “'Em algum ponto perdido deste universo, cujo clarão se estende a inúmeros sistemas solares, houve, uma vez, um astro sobre o qual animais inteligentes inventaram o conhecimento. Foi o instante da maior mentira e da suprema arrogância da história universal'”, cita Foucault $^{64}$, a partir de Verdade e mentira no sentido extra-moral, do filósofo alemão. O conhecimento pressupõe a existência de um sujeito, prévio, que conhece. Um sujeito de conhecimento. Para Foucault, como para Nietzsche, esse sujeito, assim como o conhecimento, é uma produção, não um pressuposto ${ }^{65}$. O homem não é fadado, por instinto, a conhecer. E nem o mundo existe para ser conhecido, pensam em uníssono esses dois: o que existe, instintivamente, é vontade de poder e, a partir dela é que se dá o conhecimento—ou melhor, o saber, na nova conceituação de Foucault—, um "efeito

num momento em que Foucault fala a respeito da sua relação com a política e sobre o maio de 68: "Eu não estava na França nessa época; e eu só cheguei de volta muitos meses depois. Pareceu-me que poderse-ia aí reconhecer elementos deveras contraditórios: por um lado, um esforço muito amplamente afirmado de antepor à política toda uma série de questões que não brotavam tradicionalmente de seu domínio estatutário (questão das mulheres, das relações entre os sexos, da medicina, da doença mental, do meio-ambiente, das minorias, da delinqüência); e, por outro lado, uma vontade de retranscrever todos esses problemas dentro do vocabulário de uma teoria que brotava mais ou menos diretamente do marxismo. Ora, o processo que se registrou naquele momento conduziu não à confiscação dos problemas colocados pela doutrina marxista, mas, ao contrário, a uma impotência cada vez mais manifesta do marxismo de dar cabo desses problemas." (FOUCAULT, Michel; "Polémique, politique et problematizations", in $D E I I$, texto n 342 , p. 1414)

${ }^{64}$ FOUCAULT, Michel; A verdade e as formas jurídicas, op. cit. p. 13.

${ }^{65}$ Eis o que determina a diferença entre o termo "conhecimento" e o termo "saber". Uma diferença lapidarmente exposta na entrevista dada a Trombadori: "Eu utilizo a palavra 'saber' ao estabelecer uma distinção com 'conhecimento'. Eu viso em 'saber' um processo pelo qual o sujeito sofre uma modificação por parte daquilo mesmo que ele conhece, ou antes, no ato do trabalho que ele efetua para conhecer. É aquilo que permite ao mesmo tempo modificar o sujeito e construir um objeto. É conhecimento o trabalho que permite multiplicar os objetos conhecíveis, desenvolver a sua inteligibilidade, compreender a sua racionalidade, mas mantendo a fixidez do sujeito que inquire." (FOUCAULT, Michel; "Entretien avec...", op. cit., p. 876.) 
dos instintos", tal qual "'uma centelha entre duas espadas', mas que não é do mesmo ferro que as duas espadas." ${ }^{, 66}$ Foucault assim descreve essa diferença, já perto do fim da conferência introdutória do ciclo composto por cinco palestras, quando procura afastar o "modelo que permite abordar o objeto destas conferências, o problema da formação de um certo número de domínios de saber a partir de relações de força e de relações políticas na sociedade" de "uma certa concepção do marxismo que se impôs à universidade":

"Chegamos assim a esta noção muito importante e ao mesmo tempo muito embaraçosa de ideologia. Nas análises marxistas tradicionais a ideologia é uma espécie de elemento negativo através do qual se traduz o fato de que a relação do sujeito com a verdade ou simplesmente a relação de conhecimento é perturbada, obscurecida, velada pelas condições de existência, por relações sociais ou por formas políticas que se impõem do exterior ao sujeito do conhecimento. A ideologia é a marca, o estigma destas condições políticas ou econômicas de existência sobre um sujeito de conhecimento que, de direito, deveria estar aberto à verdade. (...) $\mathrm{O}$ que pretendo mostrar nestas conferências é como, de fato, as condições políticas, econômicas de existência não são um véu ou um obstáculo para o sujeito de conhecimento mas aquilo através do que se formam os sujeitos de conhecimento e, por conseguinte, as relações de verdade. Só pode haver certos tipos de sujeito de conhecimento, certas ordens de verdade, certos domínios de saber a partir de condições políticas que são o solo em que se formam o sujeito, os domínios de saber e as relações com a verdade. Só se desembaraçando destes grandes temas do sujeito de conhecimento, ao mesmo tempo originário e absoluto, utilizando eventualmente o modelo nietzscheano, poderemos fazer uma história da verdade." 67

Essa contestação da noção de ideologia não é um ponto pequeno e sem

importância: ela fecha o ciclo de conferências e está presente na introdução de Vigiar $e$

punir.

"Não penso, portanto, que se possa admitir pura e simplesmente a análise tradicionalmente marxista que supõe que, sendo o trabalho a essência concreta do homem, o sistema capitalista é quem transforma este trabalho em lucro, em sobre-lucro ou em mais-valia. Com efeito, o sistema capitalista penetra muito mais profundamente em nossa existência. Tal como foi instaurado no século XIX, esse regime foi obrigado a elaborar um conjunto de técnicas políticas, técnicas de poder, pelo qual o homem se encontra ligado a algo como o trabalho, um conjunto de técnicas pelo qual o corpo e o tempo dos homens se tornam tempo de trabalho e força de trabalho e podem ser efetivamente utilizados para se transformar em sobre-lucro. Mas para haver sobre lucro é preciso haver sub-poder. É preciso que, ao nível mesmo da existência do homem, uma trama de poder político microscópico, capilar, se tenha estabelecido fixando os homens ao aparelho de produção, fazendo deles agentes da produção, trabalhadores. A ligação do

${ }^{66}$ FOUCAULT, Michel; A verdade e as formas jurídicas, op. cit, p. 17.

${ }^{67}$ Idem, pp. 26-27. 
homem ao trabalho é sintética, política; é uma ligação operada pelo poder. Não há sobrelucro sem sub-poder. Falo de sub-poder pois se trata do poder que descrevi há pouco e não do que é chamado tradicionalmente de poder político; não se trata de um aparelho de Estado, nem da classe no poder; mas do conjunto de pequenos poderes, de pequenas instituições situadas em um nível mais baixo. O que pretendi fazer foi a análise do sub-poder como condição de possibilidade do sobre-lucro. (...) A última conclusão é que este sub-poder, condição do sobre-lucro, ao se estabelecer, ao passar a funcionar, provocou o nascimento de uma série de saberes-saber do indivíduo, da normalização, saber corretivo-que se multiplicam nestas instituições de sub-poder fazendo surgir as chamadas ciências do homem e o homem como objeto de ciência. (...) Vemos assim como a destruição do sobre-lucro implica necessariamente $o$ questionamento e o ataque ao sub-poder; como o ataque ao sub-poder se liga forçosamente ao questionamento das ciências humanas e do homem considerado como objeto privilegiado e fundamental de um tipo de saber. Vemos também, se minha análise é exata, que não podemos situar as ciências do homem ao nível de uma ideologia que seja pura e simplesmente o reflexo e a expressão na consciência dos homens das relações de produção. Se o que disse é verdade, tanto estes saberes quanto estas formas de poder não são, acima das relações de produção, o que exprime estas relações de produção ou o que permite reconduzi-las. Estes saberes e estes poderes se encontram muito mais firmemente enraizados não apenas na existência dos homens mas também nas relações de produção. Isto porque, para que existam as relações de produção que caracterizam as sociedades capitalistas, é preciso haver, além de um certo número de determinações econômicas, estas relações de poder e estas formas de funcionamento de saber" 68

diz o primeiro. No segundo, a noção de sub-poder passa a ser referida como micropoder, como parte de um universo que os "aparelhos e as instituições viabilizam", o universo de uma microfísica do poder, cujo modelo não deve ser o do "contrato que opera uma cessão" ou o da "conquista que se apodera de um domínio", mas o da "luta perpétua", no sentido de que "esse poder se exerce muito mais do que se possui", que “ele não é o 'privilégio' conquistado ou conservado da classe dominante, mas o efeito de conjunto das suas posições estratégicas" e de que uma possível reversão desses micropoderes "não obedece à lei do tudo ou nada". Um quadro que leva a, "talvez" ser necessário

"renunciar a toda uma tradição que permite imaginar que não é possível existir saber a
não ser lá onde são suspensas as relações de poder e que o saber não possa se desenvolver
a não ser fora das suas injunções, de suas exigências e dos seus interesses. Talvez seja
necessário renunciar a crer que o poder nos torna loucos e que em troca a renúncia ao
poder é uma das condições sob as quais se pode tornar-se sábio. É necessário sobretudo
admitir que o poder produz saber (e não simplesmente favorecendo-o porque este lhe
serve ou aplicando-o porque ele lhe é útil); que poder e saber se implicam diretamente um

${ }^{68}$ Idem, pp. 125-126 (grifos meus). 
ao outro; que não há relação de poder sem a constituição correlata de um campo de saber, nem saber que não suponha ou não constitua ao mesmo tempo relações de poder. Essas relações de 'poder-saber' não devem ser portanto analisadas a partir de um sujeito que seria livre ou não em relação ao sistema de poder; mas é preciso considerar, ao contrário, que o sujeito que conhece, os objetos a conhecer e as modalidades de conhecimento são outros tantos efeitos dessas implicações fundamentais do podersaber e de suas transformações históricas. Resumindo, não é a atividade do sujeito de conhecimento que produziria um saber, útil ou recalcitrante ao poder, mas o poder-saber, os processos e as lutas que o atravessam e pelo qual ele é constituído, que determinam as formas e os domínios possíveis do conhecimento. (...) Analisar o investimento político do corpo e a microfísica do poder supõe que se renuncie-naquilo que diz respeito ao poder-à oposição violência-ideologia, à metáfora da propriedade, ao modelo do contrato ou àquele da conquista; no que diz respeito ao saber, que se renuncie à oposição daquilo que é 'interessado' e daquilo que é 'desinteressado', ao modelo do conhecimento e ao primado do sujeito." ${ }^{69}$

Se a crítica ao Estado moderno enquanto "verdade" sobre o poder, tal como visto acima, trazia consigo o tornar evidente a limitação de possibilidades de arranjos e de soluções políticas, de falas, que podem ser muito mais vastas, a crítica do uso da noção de ideologia que é conduzida, simultaneamente, por Foucault, não deixa de fazer o mesmo. Numa entrevista que ele concedeu a R. Yoshimoto, no Japão em 1978, por ocasião de uma visita àquele país, isso fica bem claro:

“o que é característico de nossa geração-provavelmente também o seja para a geração
que nos precede ou para aquela que nos segue-é, sem dúvida a falta de imaginação
política. O que é que isso significa? Por exemplo, os homens do século XVIII e os do
século XIX possuíam pelo menos a faculdade de sonhar com o futuro da sociedade
humana. A sua imaginação não descansava diante desse tipo de questões: o que é viver
como membro dessa comunidade? Ou: quais são as relações sociais e humanas? De fato,
de Rousseau a Locke ou àqueles que chamamos de socialistas utópicos, pode-se dizer que
a humanidade, ou antes a sociedade ocidental, fartava-se de produtos férteis de
imaginação sócio-política. (...) Ora, hoje, conosco, que aridez de imaginação política!
Nós só podemos nos espantar dessa pobreza. Nesse sentido, nós estamos nos antípodas
dos homens dos séculos XVIII e XIX. É entretanto possível compreender o passado
analisando o presente. Mas em matéria de imaginação política, é preciso reconhecer que
vivemos num mundo muito pobre. Quando vamos atrás de donde vem essa pobreza de
imaginação sobre o plano sócio-político do século XX, parece-me, apesar de tudo, que o
marxismo tenha tido um papel importante. Eis por que eu abordo o marxismo. Você
compreende portanto que o tema: 'como acabar com o marxismo', que serviu, de certa
forma, de fio condutor à questão que você me colocou, é igualmente fundamental para a
minha reflexão. Uma coisa é determinante: que o marxismo haja contribuído e contribua
sempre para o empobrecimento da imaginação política, esse é o nosso ponto de
partida."

${ }^{69}$ FOUCAULT, Michel; Surveiller et punir, pp. 35-36 (grifos meus).

${ }^{70}$ FOUCAULT, Michel; "Méthodologie pour la connaissance du monde: comment se débarrasser du marxisme", in $D E I I$, texto n ${ }^{\circ} 235$, p. 599. 
Hoje, passados mais de trinta anos desde que essa crítica ao uso do conceito de ideologia foi feita, é interessante notar como, ainda, persiste um apego a ele que, não obstante, incorpora essa crítica, ou parte dela, bem como o fato de que esse apego se dá por parte de autores não necessariamente identificados, explicitamente, com o marxismo-o que conduz a se pensar o quanto esse uso está mais profundamente arraigado do que se poderia, inicialmente, avaliar, havendo-se tornado uma espécie de mantra universitário, dessa instituição onde ainda se formam muitos "intelectuais universais". Um dos exemplos desse apego que incorpora a crítica, o temos num autor como Renato Janine Ribeiro que, num artigo de 2005 a respeito desse conceito, após traçar um breve histórico-mostrando como ele nasceu com Destutt de Tracy, em um contexto "positivo", para logo, por meio de Marx, adquirir um caráter de 1) "algo que é errado" e 2) que o é (errado) num sentido não inocente, sendo "socialmente necessário", ou "gerado por certa configuração das relações sociais, mantendo uma ordem política marcada pela dominação de uma classe"-, faz-lhe um reparo, numa reflexão, partindo de uma obra dos anos '60 que muito se calcou nesse conceito-Para ler o Pato Donald, de Ariel Dorfmann e Armand Mattelart-, que envolve os filmes da Disney, sobre Zé Carioca: a acusação—é para isso, no fundo, que (o conceito de) a ideologia, serve, diz o autor-de que esses filmes são "ideológicos", na medida em que mostram um par de latino-americanos, Zé Carioca e Pancho Pistolas, entregando a sua cultura, depositando-a, cordialmente, nas mãos do personagem norte-americano Donald, poderia muito bem, igualmente, ser feita, se o caso fosse o inverso, em que o famoso pato entrega a sua cultura nas mãos dos latinos. Diz Ribeiro: "esse é o risco, presente na análise da ideologia: ela corre o risco de condenar sempre." Mas, ao mesmo tempo, esse autor não quer abrir mão dessa análise, dizendo que "a teoria da ideologia (...) é uma das 
mais importantes contribuições para o conhecimento da sociedade. Ela mostra que as coisas não são o que parecem" e que "há um proveito na teoria da ideologia", equivalendo a uma "perda" o se abrir mão dela ${ }^{71}$. Algo próximo a isso ocorre com o filósofo esloveno Zlavoj Zizek que, em 1994, lançou uma coletânea de artigos a respeito do conceito e que, no seu artigo inicial, de sua autoria, reconhece que "a ideologia sempre é, por definição, 'ideologia da ideologia"” e que "não há ideologia que não se afirme distinguindo-se de outra 'mera ideologia",72, para logo, diante disso, em vez de abrir mão do conceito, insistir em encontrar, por meio da noção lacaniana de Real, uma saída, um pretenso lugar, livre da ideologia: a luta de classes, como "uma 'dificuldade', um empecilho que origina simbolizações sempre renovadas, mediante as quais nos esforçamos por integrá-lo e domesticá-lo (esse real) (...) mas que, ao mesmo tempo, condena esses esforços a um derradeiro fracasso" "73 , como o "real de um antagonismo" que, "foracluido da ficção simbólica (...) volta sob a forma de aparições espectrais" "74, permite que se faça uma crítica ideológica em que o "esteio fundamental (...) não é a 'realidade', mas o real 'recalcado' do antagonismo.",75

Esses dois exemplos, que repetem uma mesma lógica "incorporatória" da crítica foucaultiana-e o texto de Zizek faz menção explícita a essa crítica, criticando-a ${ }^{76}$-,

${ }^{71}$ RIBEIRO, Renato Janine; "Ideologia é algo tão relativo", in Cult, n $^{\circ} 89$, fevereiro /2005, ano VII, pp. 36-38.

${ }^{72}$ ZIZEK, Slavoj; "Introdução - O espectro da ideologia”, in ZIZEK, Slavoj;Um mapa da ideologia; Rio de Janeiro, Contraponto, 1999, p. 25.

${ }^{73}$ Idem, p. 27.

${ }^{74}$ Idem, p. 32.

${ }_{76}^{75}$ Idem, p. 30.

${ }^{76}$ Zizek diz que "o abandono da problemática da ideologia acarreta uma deficiência fatal na teoria de Foucault", pois esse teria que recorrer a um "remendo", a uma "retórica da complexidade, extremamente suspeita, evocando a intrincada rede de vínculos laterais, à esquerda e à direita, acima e abaixo... (...) já que nunca se pode chegar ao poder dessa maneira — o abismo que separa os micropoderes e o espectro do poder continua intrasponível." Assim, Althusser e sua análise ideológica levariam, sobre a teoria de Foucault, uma "vantagem (...) evidente" (Idem, pp. 18-19) Ora, o que se pode dizer a esse respeito é que, provavelmente, Zizek não tinha, quando escreveu essas palavras, lido, ainda, o conteúdo dos cursos dados por Foucault em 1978 e 1979, quando, como veremos, vai dar ao Estado moderno a feição de um mero episódio dentro da história mais ampla do exercício daquilo que ele denomina "poder pastoral". 
podem ser vistos como duas tentativas que caminham em sentidos opostos: uma, simplificando as coisas, a outra, complicando-as ${ }^{77}$, o que me parece, na verdade, só revelar que, no "meio-de-campo", a crítica à teoria da ideologia já está consolidada, não há muito o que se fazer - a não ser prestar um maior atenção ao que ela diz, por que diz e como diz.

${ }^{77}$ É necessário dizer que não tenho nada contra as simplificações, contra a popularização dos conceitos, desde que nela não esteja pressuposto que tudo já está resolvido no âmbito do embate mais aprofundado de idéias. Tampouco sou contra a complicação, mas desde que isso não conduza ao exagero. No caso específico do recurso de Zizek à teoria lacaniana e ao seu conceito de Real, creio mesmo que há, mais do que um exagero-pois, como veremos, uma parte deste trabalho entra numa leitura particular da obra desse autor difícil que é Lacan-, uma imprecisão, já que o conceito de Real em Lacan foi forjado num contexto em que, como mostro à frente, o que se trata é de capacitar os sujeitos a fazer escolhas, a decidir-esse conceito, "com 'R' maiúsculo", como explica o psicanalista Jorge Forbes, é "o que resiste à simbolização" sendo "inapreensível, sempre mal-entendido"(Cf. FORBES, Jorge et alli.; A invenção do futuro; Barueri, Manole, 2005, p. 37) e, como ele diz, mais à frente, "quem decide experimenta os limites da lógica" (Idem, p. 53) —e não o de justificar (servir de "esteio" a) um suposto conhecimento da realidade (ideológica, no caso, e com "r" minúsculo). 


\subsection{Capítulo 2: O poder como exercício}

Acima foram apontados dois momentos em que Foucault, dentro dos livros que compõem a arqueologia, menciona o poder—em vez da verdade—, como sendo o elemento que vai determinar o 'valor' dos enunciados, que vai ser o princípio constituinte daquilo que os define melhor: a sua raridade. O poder, tendo o saber como o seu campo de atuação privilegiado, vai consistir na delimitação daquilo que é permitido e daquilo que não é permitido enunciar, vai estabelecer regras, campos, limites de enunciação e, nisso, vai ser visto como algo que funciona por meio da interdição. Esse poder que opera nos trabalhos arqueológicos é um poder que interdita e, nisso que ele interdita, estabelece as condições daquilo que pode ser dito enquanto verdade. Mas essa concepção do modo operatório do poder-não dos seus agentes, os produtores de saberes_é algo que vai mudar; e essa mudança vai ser um dos principais elementos_-junto, talvez, com o G.I.P.—para a passagem que Foucault fez da análise dos saberes para a análise das instituições, ou melhor, para a análise da própria política, do dizer verdadeiro da política, que é viabilizado, micropolíticamente, nas instituições que compõem o Estado. Em 1970, por ocasião da sua aula inaugural no Collège de France, instituição na qual acabava de entrar, Foucault, diz que na atualidade há duas "regiões", as da sexualidade e da política, onde a grade composta pelas interdições de poder falar sobre tudo ("tabu do objeto"), de poder dizê-lo em qualquer circunstância ("ritual da circunstância") e de se possuir as credenciais para tanto ("direito privilegiado 
ou exclusivo do sujeito que fala") é "mais cerrada"78. A política, como vimos, tornouse, de fato, por meio da análise do sistema penal que vige nos Estados modernos, o tema tanto da sua ação quanto da sua reflexão. A sexualidade, como veremos, também. Mas nesse momento, a idéia que ele tem sobre o como atua o poder, é uma idéia diferente daquela que vai aparecer em Vigiar e punir, quando ele diz que "esse poder (o micropoder) muito mais se exerce do que se possui" e que a sua análise é muito mais a descrição de uma "luta perpétua" do que a de "um contrato que opera uma cessão" ou a de "uma conquista que se apodera de um domínio". É uma visão mais espacial, onde há postos a serem preenchidos ou ocupados e "buracos negros" a serem evitados, como se o tabuleiro da verdade — e o poder que nele se joga—não fosse um onde se desenhasse a cada instante o "efeito de conjunto de posições estratégicas", mas o retrato fixo de um preto-no-branco, de um tudo ou nada.

Tudo se passa como se, ao longo da arqueologia, Foucault tivesse apontado para uma prática, a dos saberes, para mostrar que neles, o que se dá, o que ocorre, é aquilo que eles negam: uma política, uma micropolítica. Neles, através deles, se dá algo que é poder: eis o que constitui a conclusão de anos de trabalho sobre os saberes. E o que é que se tem à mão como explicação sobre o poder? Bom, tem-se esses dois modelos, o contratualista, do Estado-de-Direito, e o marxista que, ambos, possuem algo em comum: que o poder diz respeito à interdição, que o poder é o que proíbe, o que diz não e que age com violência e reprime. É esse modelo que Foucault acredita ser, num primeiro instante, aquele que pode se aplicar a esses micropoderes que ele vinha descrevendo e que pretendia continuar a fazê-lo: há todo um conjunto de discursos que são impedidos de serem ouvidos, de aparecerem, de penetrarem as defesas que os

\footnotetext{
${ }^{78}$ FOUCAULT, Michel; A ordem do discurso; São Paulo, Loyola, 1999, p. 9.
} 
campos onde o verdadeiro viceja, erguem para se proteger e se preservar ${ }^{79}$. A verdade agiria como o Estado, ou, pelo menos, como se acreditava que o Estado agisse, o que poderia conduzir, se formos até as últimas conseqüências, a pensar num Foucault maoísta, apoiador de uma "revolução cultural", onde o Estado, proletário, toma para si, de forma violenta, a incumbência de destruir essas fontes de poder, "culturais", que dão sustentação, que conformam a esse outro Estado, o burguês ${ }^{80}$. Mas não demorou muito para que ele passasse a ver diferentemente. E, provavelmente, o que lhe permitiu fazer

${ }^{79} \mathrm{Em}$ A ordem do discurso, por exemplo, quando descreve um dos procedimentos internos de controle e de delimitação do discurso, as "disciplinas", ele diz, a respeito da botânica e da medicina (dois exemplos de disciplinas): "No interior de seus limites, cada disciplina reconhece proposições verdadeiras e falsas. Mas ela repele, para fora de suas margens, toda uma teratologia do saber. O exterior de uma ciência é mais e menos povoado do que se crê: certamente, há a experiência imediata, os temas imaginários que carregam e reconduzem sem cessar crenças sem memória; mas, talvez não haja erros em sentido estrito, porque o erro só pode surgir e ser decidido no interior de uma prática definida; em contrapartida, rondam monstros cuja forma muda com a história do saber. Em resumo, uma proposição deve preencher exigências complexas e pesadas para poder pertencer ao conjunto de uma disciplina; antes de poder ser declarada verdadeira ou falsa, deve encontrar-se, como diria M. Canguilhem, 'no verdadeiro'." (Idem, pp. 33-34)

${ }^{80}$ Sintomático disso é o diálogo que Foucault manteve no começo de 1972 com dois integrantes da Esquerda Proletária (maoísta) francesa, clandestina na ocasião, a respeito da justiça (FOUCAULT, Michel; "Sur la justice populaire-Débat avec les maos", in DE I, texto no 108, pp. 1208-1237), em que ele inicia dizendo que a forma do tribunal pode ser uma forma de, ao mesmo tempo, "capturar, amestrar e sufocar" a justiça popular "inscrevendo-a no interior de instituições características do aparelho do Estado", o que, por sua vez chamaria a "possibilidade de uma opressão de classe." (Idem, pp. 1208-1209) Essa maneira de colocar as coisas tende a estabelecer uma comunidade de preocupação e de crença, com os maoístas, em torno da noção de revolução proletária: é um denominador comum a ambas as partes, à época. Mas, de resto, fica clara a discordância quanto ao como. Para Foucault, esta seria inócua se continuasse a usar a forma do tribunal, herdada do sistema penal que vige desde a Idade Média nas sociedades ocidentais. Já para os maoístas, teria que existir uma instância de normatização, de aplicação de uma justiça popular, ou seja, teriam que haver "tribunais populares". Fica claro, ao longo do debate, que Foucault já usa, com relação à justiça, uma noção diversa da que se baseia na idéia de interdição: o sistema penal é uma estratégia que a classe dominante inventou: "a idéia que eu quis introduzir na discussão é a de que o aparelho de Estado burguês de justiça, do qual a forma visível, simbólica é o tribunal, tinha por função essencial introduzir e multiplicar as contradições no seio das massas, principalmente entre o proletariado e a plebe não proletarizada, e que, assim sendo, as formas de justiça e a ideologia que lhe é ligada devem tornar-se o alvo da nossa luta atual", diz Foucault no final, resumindo um ponto de vista expresso ao longo de todo o debate (Idem, p. 1236). Essa idéia vai estar presente, depois, em Vigiar e punir, quando é abordada a noção de delinqüência; o que não mais terá continuidade é a crença numa revolução: o que ele enfatiza na Revolução Iraniana, por exemplo, é a sublevação. "A revolução se organiza de acordo com toda uma economia interior ao tempo: condições, promessas, necessidades; ela se aloja na história, nela tende o seu leito e finalmente se deita. A sublevação, quanto a si, cortando o tempo, apruma os homens na vertical de sua terra e de sua humanidade", diz ele numa nota, de 1979, a respeito de um amigo falecido (FOUCAULT, Michel; "Vivre autrement le temps", in DE II, texto $n^{\circ} 268$, p. 790) De resto, esse debate com os maoístas franceses, com a sua (destes) relutância em abrir mão da forma do tribunal, comprova a tese de que os intelectuais universais da atualidade provêem, derivam, dos juristas reformadores do direito do século XVIII. 
isso foi um conceito, mais uma vez, originário—como aquela busca "do inteiramente outro" dos tempos de militância comunista—de Nietzsche: o conceito de genealogia ${ }^{81}$.

A genealogia tem como pressuposto uma diferenciação terminológica: aquela

que existe entre "origem" e "proveniência", entre a primeira e a idéia de "surgimento", tal como esclarece Foucault no importante ensaio de 1971, "Nietzsche, a genealogia e a história". A genealogia se opõe à busca da origem, diz Foucault no começo desse ensaio e, então, passa a mostrar, a partir da obra de Nietzsche, o primeiro genealogista, como.

\begin{abstract}
“Buscar uma tal origem é tentar encontrar 'aquilo que já estava lá', o 'aquilo mesmo' de uma imagem exatamente adequada a si; é ter por adventícias todas as peripécias que podem ter tido lugar, todos os ardis e todos os disfarces; é tentar tirar todas as máscaras, para desvelar enfim uma identidade primeira. Ora, se o genealogista cuida de ouvir a história muito mais do que crer na metafísica, o que ele aprende? Que por trás das coisas há 'algo inteiramente outro': não decerto o seu segredo eterno e sem data, mas o segredo de que elas são sem essência, ou que a sua essência foi construída peça a peça a partir de figuras que the são alheias. (...) Aquilo que se encontra no começo histórico das coisas não é a identidade ainda preservada da sua origem—é a discórdia das outras coisas, é o disparate." 82
\end{abstract}

Falar, descrevendo, em proveniência, em surgimento ou emergência ou invenção de algo é um modo de estar atento a tudo o que de fato ocorreu, a todas as peripécias, ardis e disfarces. "O começo histórico é baixo. Não no sentido de modesto, ou de discreto como o passo da pomba, mas derrisório, irônico, próprio a desfazer todas as

${ }^{81}$ Numa entrevista de 1977 (FOUCAULT, Michel; "Les rapports de pouvoir passent à l'intérieur des corps", in $D E I I$, texto $n^{\circ} 197$, pp. 228-236), Foucault diz que foi a sua experiência concreta com as prisões, "a partir dos anos 1971-1972", que o conduziu a tal mudança: "o caso da penalidade me convenceu de que (o poder) não era como tal em termos de direito mas em termos de tecnologia, em termos de tática e de estratégia, e foi essa substituição de uma grade jurídica e negativa por uma grade técnica e estratégica que eu tentei levar a cabo em Vigiar e punir, depois utilizar na História da sexualidade. De modo que eu abandonarei de bom grado tudo aquilo que na ordem do discurso (Foucault aqui possivelmente se refere à conferência de 1970, a respeito da qual, inclusive, gira a pergunta que lhe é feita nesta ocasião: parece haver aqui um desatenção dos editores dos Dits et écrits) pode apresentar as relações entre poder e discurso como mecanismos negativos de rarefação.” (Idem, p. 229) Apesar de tudo, dessa abjuração que Foucault atribui a um período de transição, há de se reconhecer que o fim de $A$ ordem do discurso já contempla a alternativa entre uma perspectiva que ele chama de "crítica" (que se opõe ao suposto caráter interditório do poder, o qual agiria por meio de "procedimentos de limitação dos discursos") e o "procedimento genealógico"; alternativas entre as quais "a diferença não é tanto de objeto ou de domínio mas, sim, de ponto de ataque, de perspectiva e de delimitação." (FOUCAULT, Michel; $A$ ordem do discurso, op. cit. pp. 66-67).

${ }^{82}$ FOUCAULT, Michel; "Nietzsche, la généalogie, l'histoire”, in DE I, texto n 84, p. 1006. 
enfatuações". ${ }^{83}$ Não é nada diferente do que Foucault tinha feito com relação à loucura, à medicina, aos saberes sobre o homem: na sua análise desses, ele tinha mostrado que eles não "estavam lá" desde sempre e que a sua história não seria aquela de um lento progresso rumo à sua descoberta, ao desvelamento de uma identidade primeira ${ }^{84}$. As coisas são sem essência, elas surgem, aparecem, emergem, são inventadas, provêm, muito mais do que têm uma origem; e a sua história, efetiva, é a narrativa dessas emergências, invenções, surgimentos, proveniências em vez do recontar, do ir atrás de uma origem, de perseguir um discurso ainda imperfeito para poder chegar à essência:

"do mesmo modo que se tenta muito freqüentemente procurar a proveniência numa continuidade sem interrupção, seria errado dar conta da emergência pelo termo final. Como se o olho tivesse aparecido, desde o fundo dos tempos, para a contemplação, como se o castigo tivesse sempre sido destinado a dar o exemplo. Esses fins, aparentemente últimos, não são senão o atual episódio de uma série de sujeições: o olho foi inicialmente usado na caça e na guerra; o castigo foi aos poucos submetido à necessidade de se vingar, de excluir o agressor, de se libertar em relação à vitima, de assustar os outros. Colocando o presente na origem, a metafísica faz crer no trabalho obscuro de uma destinação que buscaria vir à luz desde o primeiro momento. A genealogia, restabelece os diversos sistemas de sujeições: não a potência antecipadora de um sentido, mas o jogo ocasional das dominações. ${ }^{~} 85$

Se as coisas não têm essência, por que o poder teria? Por que ele operaria somente de um modo, possuiria uma verdade eterna? Foucault diz: "a emergência, é portanto a entrada em cena de forças; é a sua irrupção, o pulo pelo qual elas saltam dos bastidores ao teatro, cada uma com o vigor, a juventude que lhe é própria". ${ }^{86}$ Pensar

\footnotetext{
${ }^{83}$ Idem, p. 1007.

${ }^{84}$ No prefácio de $O$ nascimento da clínica, de 1963, por exemplo, Foucault afirma que, ao estarmos "historicamente consagrados à história, à paciente construção de discursos, à tarefa de ouvir o que já foi dito", temos feito isso através do comentário que "procura transformar um discurso condensado, antigo e como que silencioso a si mesmo, em um outro mais loquaz, ao mesmo tempo mais arcaico e mais contemporâneo", mas se pergunta se "não seria possível fazer uma análise dos discursos que escapasse à fatalidade do comentário, sem supor resto algum ou excesso no que foi dito, mas apenas o fato de seu aparecimento histórico? Seria preciso, então, tratar os fatos de discurso não como núcleos autônomos de significações múltiplas, mas como acontecimentos e segmentos funcionais formando, pouco a pouco, um sistema. O sentido de um enunciado não seria definido pelo tesouro de intenções que contivesse, revelando-o e reservando-o alternadamente, mas pela diferença que o articula com os outros enunciados reais e possíveis, que lhe são contemporâneos ou aos quais se opõe na série linear do tempo. Apareceria, então, a história sistemática dos discursos." (FOUCAULT, Michel; O nascimento da clínica; Rio de Janeiro, Forense Universitária, 2004, p. XIV.)

${ }^{85}$ FOUCAULT, Michel; "Nietzsche, la généalogie, l'histoire”, op. cit., p. 1011.

${ }^{86}$ Idem, p. 1012.
} 
que o poder seja o puro exercício da interdição seria deixar de ver as forças que o compõem dando esse salto para ocupar o centro das atenções, o palco onde irão representar os papéis de maior ou menor expressão, de mais ou menos destaque, tal como os atores de uma companhia de teatro ${ }^{87}$. E o resultado dessa disputa é sempre algo em aberto: quem tem mais vigor, mais juventude, quem não é nem mesmo mais capaz de saltar? Fazer a genealogia é mesmo descrever os movimentos de uma "luta perpétua" ${ }^{88}$, percorrer os bastidores de onde é encenada uma peça que não tem um script fechado, que é inventada a cada novo movimento por atores que necessitam a cada instante mostrar o seu valor, mostrar que dão conta de estar na ribalta, convencendo a

\footnotetext{
${ }^{87}$ Veyne, no seu estudo já citado ("Foucault révolutionne l'histoire”), de 1978, em pelos menos duas ocasiões aborda o poder como uma objetivação, algo que não existe por si, mas que é resultado de uma prática. "É seguramente uma coisa curiosa, bastante digna de intrigar um filósofo, essa capacidade que têm os homens de ignorar seus limites, sua raridade, de não enxergar que há vazio em torno de si, de se crer cada vez instalados na plenitude da razão", diz ele, para, em seguida mostrar o que acontece quando essa raridade é percebida: "o mais característico é o instante em que a rarefação se produz; ela não toma forma, ao contrário: é muito mais um desligamento. No instante anterior, não havia nada a não ser uma grande coisa lisa que mal podia ser vista, de tanto que era evidente e que se chamava 'o' Poder ou 'o' Estado; nós, por nossa conta, estávamos tentando erguer um pedaço de história em que esse grande nó translúcido desempenhava utilidades, bem como nomes comuns e conjunções; mas isso não funcionava, algo não se encaixava redondamente e os falsos problemas verbais do tipo 'ideologia' ou 'relação de produção', eram eles mesmos que rodavam. De uma hora para outra, nos 'demos conta' de que todo o mal vinha do grande nó, com o seu falso natural; que era preciso deixar de acreditar que ele era evidente, mas reduzí-lo à comum condição, historicizá-lo." (VEYNE, Paul; Comment on écrit l'histoire, p. 401). Mais adiante, ao aprofundar o aspecto "positivista"-ele chama Foucault de "o primeiro historiador completamente positivista" (Idem, p. 386) — dessa abordagem histórica, diz: "A análise histórica começa por estabelecer que não existe Estado, nem mesmo Estado romano, mas somente correlatos (rebanho a guiar, fluxo a gerir) de práticas datadas as quais cada uma, a seu tempo, parecia ser evidente e ser a própria política. Ora, como só existe o que é determinado, o historiador não explica a política em si, mas o rebanho, o fluxo e outras determinações, pois a política, o Estado e o Poder, isso não existe." (Idem, p. 419)

${ }^{88}$ A filósofa Scarlett Marton, num texto intitulado "Foucault leitor de Nietzsche", faz um interessante exercício no qual indaga se, para além da "leitura (que) Foucault faz de Nietzsche", nessa leitura não haveria elementos que configuram, no fundo, uma oposição, ou uma resistência. Os argumentos para tal conduzem a uma dúvida levantada quanto a Nietzsche ser, como afirmado por Foucault, "'o filosofo do poder, mas que chegou a pensar o poder sem se encerrar no interior de uma teoria política"'(MARTON, Scarlett; "Foucault leitor de Nietzsche", in RIBEIRO, Renato Janine (org.);Recordar Foucault—os textos do colóquio Foucault; São Paulo, Brasiliense, 1986, p. 44) : haveria nele uma "teoria das forças" que iria além da mera necessidade, "filológica", apontada e louvada por Foucault, de interpretar as interpretações ou de, "em termos mais precisamente nietzscheanos", avaliar as avaliações e que remete a um pensamento sobre o critério que embasaria essas avaliações. Sendo esse critério "a vida", a obra de Nietzsche, sua genealogia, abrigaria uma cosmologia que lhe serviria de base: "o procedimento genealógico encontra seu critério numa tese cosmológica: a vida concebida como uma pluralidade de forças, agindo e resistindo umas em relação às outras" (idem, p. 45) e não seria, meramente, como para Foucault, um jogo entre forças que atuam "apenas" na "esfera humana" (idem, p. 43).
} 
platéia a respeito da veracidade dos seus personagens, criando nela a ilusão de que é feito o teatro. O poder é produtivo, no mesmo sentido que o teatro. É como uma peça encenada à qual as pessoas vão assistir; e que tem que convencer para que elas continuem a fazê-lo e para que chamem os seus amigos e conhecidos para que o façam $^{89}$.

Eis então que a palavra poder pode e necessita passar a ser qualificada: há diversos poderes, assim como há diversos tipos de teatro e diversas peças. Há, certamente, o poder que diz não, mas este talvez não seja senão um aspecto, um momento fugaz de um poder que diz sim constantemente, tal como é o caso do poder disciplinar, que age sobre os corpos, adestrando-os. Esse poder disciplinar, produtivo, que funciona pela afirmação, é um poder que foi inventado num determinado momento da história do ocidente: num determinado instante, ele emergiu, surgiu, pulou no palco e começou o seu show. Vigiar e punir, em sua terceira e última parte, vai ser a genealogia desse poder, vai descrevê-lo tal como se pode fazer a biografia de um ator, contar a respeito da sua infância, suas influências, seus amores, os personagens que representou, os filhos que deixou. Vai mostrá-lo com produtor de "realidade", como o principal elemento—ator/personagem—de uma peça triste ou trágica, que nunca saiu de cartaz desde a sua estréia e que poderia receber o título de Prisão.

${ }^{89}$ Que ele tenha que convencer está implícito na descrição que Foucault faz da emergência como um "lugar de afrontamento", que é "de preferência (...) um 'não-lugar', uma pura distância, o fato que os adversários não pertencem ao mesmo espaço. Ninguém é portanto responsável por uma emergência; ninguém pode se auto-glorificar por ela; ela sempre se produz no interstício." (FOUCAULT, Michel; "Nietzsche, la généalogie, l’histoire", op. cit., p. 1012) 


\subsubsection{Sexo, poder e sexualidade}

Em nenhum outro local da obra de Foucault, porém, a explicitação do caráter produtivo do poder é mais evidente do que em A vontade de saber, o volume I da História da sexualidade. O tema desse livro, certamente, é mais uma "objetivação": o sexo e tudo o que gira em torno dele, a sexualidade, e os discursos que a produzem, mas, como ele diz na entrevista de 1977—um ano após a sua publicação—“Les rapports de pouvoir passent à l'intérieur du corps", "o essencial do trabalho é uma reelaboração da teoria do poder e eu não estou certo de que o puro prazer de escrever sobre a sexualidade teria me motivado suficientemente para iniciar esta série de seis volumes (ao menos), se eu não tivesse me sentido movido pela necessidade de retomar um pouco essa questão do poder." 90 De fato, a segunda metade dele é quase que pura teoria do poder, ainda que sempre respaldada, com exclusividade, pelo exemplo"privilegiado, porque lá, melhor do que em qualquer outro lugar, o poder parecia

\footnotetext{
${ }^{90}$ FOUCAULT, Michel; "Les rapports de pouvoir passent à l'intérieur du corps", op. cit., p. 231. Note-se que no momento em que concedeu essa entrevista, Foucault ainda pensava que a "História da sexualidade" seria uma série de estudos que gravitariam em torno da moderna relação entre poder e sexo, cujos prolegômenos, apenas, estariam em A vontade de saber. Como é sabido, os dois outros volumes dessa História que saíram-haveria um quarto, que não veio a lume devido à morte do autor, mas que acompanhava a linha, tudo indica, desses dois últimos-tratam dessa relação, mas num contexto bem diverso, o da Antigüidade clássica e começos do cristianismo, o que lhe dá feições completamente diferentes, como será visto mais adiante.
} 
funcionar como interdição" $" 91$-que havia sido historiado na primeira parte: a sexualidade.

E o que é que o exemplo da sexualidade nos mostra? Bem, que existe em nossas sociedades algo ao que Foucault dá o nome de dispositivo da sexualidade, e que um dos principais elementos desse dispositivo é uma incitação permanente a falar de sexo, uma incitação que se dá por meio da afirmação constantemente repetida de que haveria, no que lhe diz respeito, uma repressão em vias de acontecer, haveria toda uma pudicícia que mantêm o sexo e tudo o que diria respeito a ele, não dito, inconfessado; seria, portanto, imperativo, dizê-lo, confessá-lo, trazê-lo à luz do dia. É a isso o que Foucault dá o nome de "hipótese repressiva", cuja descrição abre $A$ vontade de saber com uma série de condicionais: "diz-se", narra Foucault, que tal "seria" a situação, que tal outra coisa "teria" acontecido: a moderna repressão do sexo. Mas Foucault não compra esse discurso, fácil na medida em que, como ele mostra, se mistura com o de uma crítica ao capitalismo e adquire as características de uma predicação: "sustentar um discurso no qual se juntam o ardor do conhecer, a vontade de mudar a lei e o jardim esperado das delícias-eis o que alimenta, sem dúvida, em nós, o apego a falar do sexo em termos de repressão."92 Ele vai sustentar o contrário; que, longe de ser uma denúncia do poder, essa denúncia dele como algo que se exerce por meio de uma proibição-e a conseqüente injunção a saber e a falar do sexo e de tudo aquilo que, como este, seria o seu contrário, de tudo aquilo que por ele seria recalcado-, é, na verdade, o próprio exercício de um poder, é uma forma do poder se esconder.

“Um sobrevôo preliminar", diz ele no fim da sua introdução,

\footnotetext{
${ }^{91}$ FOUCAULT, Michel; Histoire de la sexualité I-La volonté de savoir; Paris, Gallimard, 2004, p. 119.

92 Idem, p. 14. Note-se a diferença em relação à posição que ele havia manifestado em $A$ ordem do discurso, de que os discursos sobre o sexo e sobre a política seriam a regiões do discurso mais sujeitas à interdição.
} 
"parece indicar que desde o século XVI, a 'colocação em discurso' do sexo, longe de sofrer um processo de restrição, foi submetida, pelo contrário, a um mecanismo de incitação crescente; que as técnicas de poder que se exercem sobre o sexo não obedeceram a um princípio de seleção rigorosa mas, ao contrário, de disseminação e de implantação das sexualidades polimorfas e que a vontade de saber não se deteve diante de um tabu a ser mantido incólume, mas que ela se obstinou—sem dúvida através de muitos erros-em constituir uma ciência da sexualidade." ${ }^{93}$

Os dois capítulos seguintes, intitulados, respectivamente, "A hipótese repressiva" e "Scientia sexualis" — o primeiro desses subdividido em duas partes, "A incitação aos discursos" e "A implantação perversa"—são, de fato, a explicitação desses três pontos, aquilo que seria uma espécie de evidenciação histórica, a genealogia mesma desse poder, que age incitando e multiplicando, diversificando, fazendo variar os focos de enunciação discursiva sobre o sexo-—uma censura massiva, a partir das decências verbais impostas pela época clássica? Trata-se antes de uma incitação regrada e polimorfa aos discursos" 94 , que "produz e fixa o disparate sexual"-a sociedade moderna sendo "perversa realmente e diretamente",95, ampliando, assim como faz com o ilegalismo popular, as "linhas de penetração" de um controle e de uma vigilância, desta feita promovidos pela pedagogia e pela terapêutica, sobre práticas que antes não recebiam atenção nenhuma-e que se encarrega de produzir uma "verdade" sobre o sexo-““(...) que o sexo não tenha sido somente assunto de sensação e de prazer, de lei ou de interdição, mas também de verdadeiro e de falso"96-, atualizando esse mecanismo, a confissão, que "desde a Idade Média", está "dentre os principais rituais dos quais se espera a produção de verdade" $" 97$ e que "foi (no Ocidente), e ainda o é, a matriz geral que rege a produção do discurso verdadeiro sobre o sexo"98. Tudo conflui para a idéia de um dispositivo de sexualidade, título do quarto capítulo do livro: e o que

\footnotetext{
${ }^{93}$ Idem, pp. 21-22.

${ }^{94}$ Idem, p. 47.

${ }^{95}$ Idem, p. 65.

${ }^{96}$ Idem, p. 76

${ }^{97}$ Idem, p. 78.

${ }^{98}$ Idem, p. 84.
} 
é um dispositivo senão algo que cria, que produz, em vez de algo que proíbe ${ }^{99}$ Assim encerra Foucault esses capítulos que pretendiam ser introdutórios, mas que acabaram por permanecer como único suporte histórico da elaboração fundamentalmente teórica que lhes segue:

"Pode ser que essas análises históricas (por vir) terminarão por dissipar isso que parece
sugerir este primeiro percurso. Mas o postulado de partida que eu gostaria de defender o
mais longamente possível, é que esses dispositivos de poder e de saber, de verdade e de
prazeres, esses dispositivos, tão diferentes da repressão, não são forçosamente
secundários e derivados; e que a repressão não é de todo modo fundamental e vencedora.
Trata-se portanto de levar a sério esses dispositivos, e de inverter a direção da análise:
muito mais do que uma repressão geralmente reconhecida, e de uma ignorância avaliada
de acordo com o que supomos saber, é preciso partir desses mecanismos positivos,
produtores de saber, multiplicadores de discursos, indutores de prazer, e geradores de
poder, seguí-los na sua condição de aparição e de funcionamento e buscar como se
distribuem em relação a eles os fatos da interdição ou ocultação que lhes são ligados.
Trata-se, em suma, de definir as estratégias de poder que são imanentes a essa vontade de
saber. Sobre o caso específico da sexualidade, constituir a 'economia política' de uma
vontade de saber."100 Foucault diz, logo nas primeiras páginas de "O dispositivo de sexualidade", na parte em que se empenha em explicitar aquilo que estará em jogo nas análises que virão, que tratar-se-á de “avançar menos na direção de uma 'teoria' do que na direção de uma 'analítica' do poder (...) rumo à definição do domínio específico que formam as relações de poder e à determinação dos instrumentos que permitem analisá-lo." ${ }^{101}$ É o que de fato faz ao longo de todo o capítulo, num jogo que, ao mesmo tempo, acrescenta muito pouca novidade em relação àquilo que, sobre o poder, vinha dizendo desde Vigiar $e$ punir e conduz no sentido de uma formulação que, como veremos adiante, estava destinada a ter uma morte lenta, confundindo-se com a própria morte do projeto inicial,

\footnotetext{
${ }^{99}$ Uma boa discussão sobre o conceito de dispositivo está no começo de um diálogo de 1977 em que Foucault assim o define, dentre outras características - de ser uma "rede" que se estabelece entre elementos heterogêneos que, por sua vez, se ligam entre si de formas diversas e variáveis-: "por dispositivo, eu entendo uma espécie—digamos—de formação, que num dado momento histórico, teve por função primordial responder a uma urgência. O dispositivo tem, portanto, uma função estratégica." Ele estaria "sempre inscrito no jogo de poder, mas sempre ligado também a um ou aos limites de saber, que nele nascem, mas que, ao mesmo tempo, o condicionam. É isso o dispositivo: estratégias de relações de força dando suporte a tipos de saber e sendo sustentadas por eles." (FOUCAULT, Michel; "Le jeu de Michel Foucault", in DE II, texto n ${ }^{\circ} 206$, pp. 299-300)

${ }^{100}$ FOUCAULT, Michel; Histoire de la séxualité I..., op. cit., pp. 97-98.

${ }^{101}$ Idem, p. 109.
} 
com seus seis volumes, da História da sexualidade; uma morte selada, acredito eu, pelas afirmações de que ele, Foucault, não é "de modo algum um teórico do poder" e pelo conteúdo da introdução do volume II da História da sexualidade, quando anuncia "modificações": a morte da formulação do biopoder.

Sobre o primeiro desses aspectos, o do poder, sim, são importantes as páginas em que ele mostra como é necessário, para que a analítica visada aconteça, afastar-se do modelo "jurídico-discursivo" de apreensão do poder; um modelo que faz o poder girar em torno do problema da soberania_Foucault a certa altura se refere a um "sistema Soberano-Lei" " — que é comum tanto aos defensores da "hipótese repressiva" quanto aos formuladores de uma "teoria do desejo"—que advogam que o próprio desejo, aquilo que é oposto ao poder, ou melhor, objeto sobre o qual a repressão se exerceria, é, por si mesmo, constituído pela falta, pela enunciação da lei que proíbe-, mas que também é o modelo que tanto os reformadores do direito penal e os revolucionários que derrubaram o Antigo Regime-para virem, juntos, a implantar um Estado-de-Direito—, tanto esses, quanto os outros críticos mais "radicais" que procuravam mostrar que "não só o poder real escapava às regras do direito, mas que o direito em si não era mais do que uma maneira de exercer a violência" ${ }^{103}$, compartilhavam e compartilham no que diz respeito ao poder: eles, ainda que se oponham ao "abuso" do poder, simbolizado seja pelo poder monárquico ou burguês com características de monárquico, para defender um "sistema jurídico puro, rigoroso", esquecem-se de que o direito foi, para a monarquia, como já havia mostrado Foucault em $A$ verdade $e$ as formas jurídicas, mais do que "simplesmente uma arma habilmente manipulada (...) seu modo de manifestação e a

\footnotetext{
${ }^{102}$ Idem, p. 128.

${ }^{103}$ Idem, pp. 116-117.
} 
forma de sua aceitabilidade." 104 Sim, é importante mostrar que "no pensamento e na análise política ainda não cortamos a cabeça do rei”"105, mas isso, em si, é uma reafirmação, uma centagésima-primeira repetição ${ }^{106}$, de algo que Foucault já vinha afirmando há tempos. Sim, é importante afirmar um nominalismo dizendo que "o poder não é uma instituição, e não é uma estrutura, não é uma certa potência da qual alguns seriam dotados; é o nome que se dá a uma situação estratégica complexa dentro de uma dada sociedade" 107 , mas não é esse nominalismo algo que Foucault já vinha praticando há pelo menos quinze anos quando começou a dizer, "inimigo das árvores" no dizer de Veyne-e num sentido muito próximo ao de Alberto Caeiro/Fernando Pessoa-, que "coisas" como a loucura, a doença, o homem, não "existem" — sem dizê-lo textualmente, é verdade, como conta esse mesmo comentador ${ }^{108}$ ? E não continuaria a fazê-lo no próprio livro, quando define a sexualidade como

"o nome que se pode dar a um dispositivo histórico: não realidade subjacente sobre a qual se exercem apreensões difíceis, mas grande rede de superfície onde a estimulação dos corpos, a intensificação dos prazeres, a incitação ao discurso, a formação de conhecimentos, o reforço dos controles e das resistências se encadeiam uns aos outros de acordo com algumas grandes estratégias de saber e de poder" ${ }^{\text {109, }}$,

e quando, já no seu final, rejeita a noção de sexo como ponto de ancoragem que dá sustentação às "manifestações da sexualidade" e diz que "é justamente essa idéia do sexo que não podemos aceitar sem exame", pois,

${ }^{104}$ Idem, p. 115.
${ }^{105}$ Idem, p. 117.
${ }^{106}$ Idem, p. 107.
${ }^{107}$ Idem, p. 123.
${ }^{108}$ Cf. VEYNE, Paul; "Foucault revolutionne l'histoire", op. cit., p. 414: "Estaríamos errados em acusar esse pensador, que acredita que a matéria é em ato, de ser um idealista (no sentido popular do termo). Quando eu mostrei a Foucault as presentes páginas, ele me disse mais ou menos o seguinte: 'Eu pessoalmente jamais escrevi que a loucura não existe, mas isso se pode escrever; posto que, para a fenomenologia, a loucura existe, mas ela não é uma coisa, ao passo que é preciso, ao contrário, dizer que a loucura não existe, mas que nem por isso ela não é nada". Palavras semelhantes se encontram no curso de 1978, Sécurité, territoire, population (cf. FOUCAULT, Michel; Sécurité, territoire, population; Paris, Gallimard-Seuil, 2004, p. 122) Sobre as "árvores", cf. VEYNE, Paul, "Foucault revolutionne l'histoire", op. cit p. 417.

${ }^{109}$ FOUCAULT, Michel; Histoire de la sexualité I..., op. cit., p. 139. 
"em toda a extensão das grandes linhas ao longo das quais se desenvolveu o dispositivo da sexualidade desde o século XIX, vê-se elaborar essa idéia de que existe outra coisa além de corpos, de funções, de sistemas anátomo-fisiológicos, de sensações, de prazeres; algo de outro e de mais, algo que tem as suas propriedades intrínsecas e suas leis próprias: o "sexo" "110?

Sim, é interessante a diferenciação entre o dispositivo de sexualidade e o velho, mas ainda atuante e re-atualizado, dispositivo da aliança, o primeiro trazendo a novidade de ter o corpo, "que produz e que consome""111, como principal articulação com a economia, mas essa articulação já não havia sido apontada, não constituía o cerne do poder disciplinar? Sim, dá o que pensar todo o jogo estratégico que ocorre entre as classes sociais em que a burguesia, ao contrário do que acreditam alguns, não atua sob os preceitos de uma filosofia nem idealista nem castradora, mas se preocupa em "se dar um corpo e uma sexualidade—de assegurar a força, a perenidade, a proliferação secular desse corpo pela organização de um dispositivo de sexualidade"112 e somente sob determinadas condições_o dispositivo não funcionando "de maneira simétrica aqui e lá,"113 — admite a extensão desse dispositivo às classes subordinadas-e onde a psicanálise atuaria como "mecanismo secundário de diferenciação", na medida em se dá por função a de, "na prática, (...) suspender, para aqueles que estão em posição de a ela recorrer, os efeitos de recalque que ela (a interdição do incesto) pode induzir; ela lhes permite articular em discurso o seu desejo incestuoso"114_, mas em quê essa complexidade estratégica se diferencia daquela que Foucault explicitara, na conversa com os maoístas franceses, em relação à forma do tribunal, esse "símbolo" do "aparelho de Estado burguês de justiça"?

\footnotetext{
${ }^{110}$ Idem, p. 201.

111 Idem, p. 141.

112 Idem, p. 166.

${ }^{113}$ Idem, p. 168.

114 Idem, p. 171.
} 
É bem verdade, não sejamos injustos: há ao menos dois aspectos novos sobre o poder em "O dispositivo de sexualidade", ambos tendo a ver com a liberdade. O primeiro diz respeito ao por que do poder ter que se apresentar como sendo repressor, ter de aparecer sob um manto jurídico-discursivo quando, na verdade, ele produz, ele incita, ele conduz, ou, no mínimo, arma as estratégias para poder conduzir. É que essa forma de se apresentar, esse disfarce, é um que diz que "apesar da minha ruindade, ainda assim eu sou bom porque significo, nisso que eu reprimo, que eu permito, para além do campo da minha repressão, uma margem de liberdade", é um que promete "uma 'liberação","115; diz Foucault:

“é sob a condição de esconder uma parte importante de si mesmo que o poder é tolerável. Seu sucesso é proporcional àquilo que ele chegue a esconder de seus mecanismos. O poder seria aceito se fosse inteiramente cínico? O segredo não é para ele da ordem do abuso: ele é indispensável ao seu funcionamento. E não somente porque ele o impõe àqueles que ele sujeita, mas talvez porque ele é para estes de todo também indispensável: aceitariam-no, se eles não vissem aí um mero limite imposto ao seu desejo, deixando valer uma parte intacta—mesmo que reduzida — de liberdade? O poder, como puro limite traçado à liberdade, é, na nossa sociedade ao menos, a forma geral de sua aceitabilidade." $" 116$

O segundo ocorre quando, descrevendo o "método" que deverá adotar ao longo dos próximos anos em que irá (iria) se dedicar ao dispositivo de sexualidade, esboça algumas proposições sobre o poder; dentre elas está uma última, a quinta, que se destaca como uma novidade em relação ao que já havia dito antes-e que irá frutificar no futuro da sua obra, conforme veremos logo a seguir-: basicamente que uma resistência, ou melhor, resistências ao poder-ao poder real tal como ele o entende e não ao poder do modelo "jurídico-discursivo"—são algo que faz parte do próprio poder, são algo que o constitui. Diz Foucault, sobre elas: “elas são o outro termo nas relações de poder; elas nelas se inscrevem como o irredutível vis-à-vis", distribuindo-se, disseminando-se, dispersando-se de maneira irregular, como o próprio poder, de tal modo que

\footnotetext{
115 Idem, p. 109.

${ }^{116}$ Idem, pp. 113-114.
} 
"assim como a rede das relações de poder termina por formar um espesso tecido que atravessa os aparelhos e as instituições sem se localizar exatamente nelas, igualmente a dispersão de pontos de resistência atravessa as estratificações sociais e as unidades individuais. E é sem dúvida a codificação estratégica desses pontos de resistência que torna possível uma revolução, um pouco como o Estado repousa sobre a integração institucional das relações de poder." 117

Mas há também a questão do biopoder, que ocupa todo o último capítulo do

livro, "Direito de morte e poder sobre a vida", como verdadeira novidade, como uma

espécie de resultado de toda essa peripécia teórica em torno do poder, mas também como o grande ponto de apoio para as pesquisas que virão (viriam). Foucault faz uma primeira referência a ele em meio, ainda, ao capítulo sobre o poder, quando diz que a forma jurídico-monárquica de pensá-lo seria, "apesar de tudo", uma forma "transitória":

"pois se muitas de suas formas têm subsistido e subsistem ainda, mecanismos de poder muito novos, provavelmente irredutíveis à representação do direito, o têm aos poucos penetrado. Veremos isso mais à frente, esses mecanismos de poder são sob um aspecto ao menos esses que têm tomado conta, a partir do século XVIII, a vida dos homens, os homens como corpos vivos." 118

Esse é o momento em que Foucault parece atravessar uma linha delimitadora do seu trabalho até então, uma linha que só o tempo lhe fez perceber que havia ultrapassado: ele deixa de analisar discursos com pretensão de verdade que são, na verdade, componentes de exercícios de relações de poder, para passar a descrever uma "verdade", a verdade de como se deu o poder a partir de determinado momento. Caminhando num sentido oposto ao que concebe a filosofia como "uma reflexão sobre a nossa relação com a verdade, muito mais do que uma sobre o que é verdadeiro e o que é falso", a certa altura, no final da parte metodológica de "O dispositivo de sexualidade", ainda, diz ele:

"trata-se em suma de se orientar rumo a uma concepção do poder que, ao privilégio da lei, substitui o ponto de vista do objetivo, ao privilégio do interdito, o ponto de vista da eficácia tática, ao privilégio da soberania, a análise de um campo múltiplo e móvel de relações de força onde se produzem efeitos globais, mas nunca totalmente estáveis, de dominação. O modelo estratégico muito mais do que o modelo do direito. E isso não por

${ }^{117}$ Idem, p. 127.
${ }^{118}$ Idem, p. 117. 
escolha especulativa ou preferência teórica; mas porque de fato é um dos traços fundamentais das sociedades ocidentais que as relações de força que por muito tempo tinham encontrado na guerra, em todas as formas de guerra, a sua expressão principal, incrustaram-se pouco a pouco na ordem do poder político." 119

A fórmula "as relações de força como expressão da guerra", consubstanciada na inversão do aforismo clausewitziano da guerra como sendo a continuação da política por outros meios-ou seja, de que a política seria a continuação, na verdade, da guerra, por outros meios-, ou, a guerra como "gabarito de inteligibilidade" ou "analisador geral" das relações sociais e do "discurso da história", eis aí o tema ao qual Foucault, de fato, dedicou todo o curso de 1976 no Collège de France, "Em defesa da sociedade", indo atrás da emergência de um discurso de tal ordem ${ }^{120}$ e deparando-se com o discurso da luta e da "guerra das raças" na Inglaterra dos séculos XVI e XVII e França do final do século XVII, bem como dos seus desdobramentos mais recentes, como o "racismo de Estado"—que seria a solução para o paradoxo que se apresenta com a coexistência da injunção de matar o "inimigo" e da autorização para tal, próprios, respectivamente, dessa inteligibilidade guerreira das relações sociais e do poder soberano, e "essa tecnologia de poder que tem como objetivo a vida" (defasando "no interior da população, uns grupos em relação aos outros" ${ }^{121}$ ). Com a formulação do biopoder-um poder “destinado a produzir forças, a fazê-las crescer e a ordená-las muito mais do que a barrá-las, a dobrá-las ou a destruí-las""122 e que "se dá, por função, a de gerir a

\footnotetext{
${ }^{119}$ Idem, p. 135, grifo meu.

120 “(...) a questão principal que eu gostaria de estudar este ano seria esta: como, desde quando e por que se começou a perceber ou a imaginar que é a guerra que funciona sob e nas relações de poder”, anuncia Foucault na terceira aula (FOUCAULT, Michel; Em defesa da sociedade; São Paulo, Martins Fontes, 2002, p. 54).

121 Idem, p. 304. Acrescenta Foucault: "Em linhas gerais, o racismo, acho eu, assegura a função de morte na economia do biopoder, segundo o princípio de que a morte dos outros é o fortalecimento biológico da própria pessoa na medida em que ela é membro de uma raça ou de uma população, na medida em que se é elemento numa pluralidade unitária e viva. (...) A especificidade do racismo moderno, o que faz sua especificidade, não está ligado a mentalidades, a ideologias, a mentiras do poder. Está ligado à técnica do poder, à tecnologia do poder. Está ligado a isto que nos coloca, longe da guerra das raças e dessa inteligibilidade da história, num mecanismo que permite ao biopoder exercer-se" (Idem, pp.308-309).

${ }^{122}$ FOUCAULT, Michel; Histoire de la séxualité I..., op. cit., p. 179.
} 
vida"123 — Foucault, ainda que o tenha tentado fazer baseado na análise discursiva ${ }^{124}$ e como que tomado pelo entusiasmo de ter, após tantos anos de indagação crítica a respeito do poder, encontrado uma explicação—uma teoria—muito bem fundamentada e inteiramente nova, entra no campo do discurso factual, interpretativo da história: o poder tem sido, desde tal momento, isso; "o Ocidente tem conhecido, desde a época clássica, uma transformação muito grande dos seus mecanismos de poder"125, diz ele, como se fosse um historiador, não dos discursos, das "verdades", mas de uma realidade, de um "fato" acontecido e, a partir disso, formulasse a sua verdade do poder, ou iniciasse um percurso nesse sentido. Uma interpretação, aliás, que, com o tempo irá ser bastante matizada, como veremos.

Por ora, contudo, acompanhemos o entusiasmo. Foucault teve licença sabática do Collège de France em 1977, só voltando no ano seguinte às suas aulas. Essas, tanto as anteriores quanto as posteriores, por sua vez, estão carregadas de afirmações entusiásticas tanto quanto à guerra, como quanto à biopolítica. Em Em defesa da sociedade, por exemplo, lê-se a de que chegara-se ao fim de uma era nas suas aulas: de

${ }^{123}$ Idem, p. 181.

${ }^{124}$ Eis inclusive um problema da leitura de Em defesa da sociedade: onde está a divisão entre o discurso da guerra de raças e de seus continuadores, objeto de sua análise, e o entendimento do próprio Foucault a respeito da realidade do poder, da sua crítica à concepção jurídico-discursiva no que lhe diz respeito? Seria Foucault um herdeiro de Boulainvilliers - um dos principais representantes desse discurso guerreiro sobre a história e sobre a sociedade-, ao conceber o poder, como o faz nas primeiras aulas desse curso, como jogo estratégico entre forças, como algo que "transita entre os indivíduos, não se aplica a eles" (FOUCAULT, Michel; Em defesa..., op. cit. p. 35), como "estratégias globais que perpassam e utilizam táticas locais de dominação" (Idem, p. 52)? Eis uma pergunta que permanece em aberto, parece-me, até se perceber que, apesar do esforço em mostrar o caráter de "discurso verdadeiro" do discurso da guerra de raças - a guerra sendo uma "matriz de verdade do discurso histórico" (Idem, p. 197)—o curso de 1976 é, antes de mais nada, um surpreendente e muito rico subsídio documental para a afirmação-histórica, e não teórica-de que o poder tem se dado, no Ocidente, assim: segundo o modelo da guerra. Ou seja, nada de filiação a Boulainvilliers: ele é apenas uma evidência que dá suporte a uma interpretação histórica; não mantêm nenhuma relação teórica com Foucault — ainda que ele abra a terceira aula com um elogio a esse discurso, por ser ele uma "contra-história"; mas, não se deve deixar de atentar-"glória e infâmia do discurso das raças em luta" - para o fato de que, igualmente, fecha a aula seguinte perguntando-se: "e se Roma conquistasse novamente a revolução?", após narrar que "Petrarca se perguntava 'que há na História que não seja louvação de Roma?"” e dizer que "pois bem, nós—e é isso que decerto caracteriza a nossa consciência histórica e que está vinculado ao aparecimento dessa contra-história—, nós nos perguntamos 'Que há na história que não seja apelo à revolução ou ao medo dela?'” (Idem, p. 98.)

${ }^{125}$ FOUCAULT, Michel; Histoire de la sexualité I..., op. cit., p. 179. 
que desse ponto em diante-estamos no começo do curso-não se teria mais esse conjunto de pesquisas "fragmentárias", "dispersas" e "repetitivas", "nenhuma das quais chegou finalmente ao seu termo"126 (como se não existissem nem Vigiar e punir nem A vontade de saber), que ele conduzira nessa instituição nos últimos cinco anos, mas um projeto de mais longa duração: "nos cinco anos seguintes, a guerra, a luta, o exército",127, ou, como diz um pouco antes_precedido de um salvador "sei lá", quanto ao tempo de duração—, "esse problema da guerra na sociedade civil" 128 . Bom, o mínimo que se há de dizer quanto a isso é que o tema da guerra não passou, em sua duração, de um ano: não aparece mais após esse curso de 1976. Quanto ao biopoder, bom, aí já se trata de uma outra história, em que o entusiasmo é manifesto reiteradamente ao longo de dois anos de curso, mas, ao contrário do tema da guerraque mereceu todo um ano de dedicação-, viu-se sempre sendo superado por outros entusiasmos, por outros temas, o que finalmente o levaria ao seu ocaso, ao seu desaparecimento, sem que nada a seu respeito tenha, mais, sido aventado. Surpreendente? Certamente, ainda mais que o título do curso de 1979, Naissance de la biopolitique, faça diretamente uso da expressão! Mas, senão, vejamos: as próprias declarações ao longo tanto desse curso quanto do anterior de que irá tratar desse tema, são a própria confirmação de que ainda não havia entrado nele. E elas se repetem:

"este ano, eu gostaria de começar o estudo de algo que eu tinha denominado, um pouco assim meio no ar, o biopoder, isto é, essa série de fenômenos que me parece bastante importante, a saber: o conjunto de mecanismos por meio dos quais aquilo que na espécie humana constitui seus traços biológicos fundamentais vai poder entrar no interior de uma política, de uma estratégia política, de uma estratégia geral de poder, ou, dito de outra forma, como a sociedade, as sociedades ocidentais modernas, a partir do século XVIII retomaram em conta o fato biológico fundamental que o ser humano constitui uma espécie humana." 129

\footnotetext{
${ }^{126}$ FOUCAULT, Michel; Em defesa..., op. cit., p. 6.

${ }^{127}$ Idem, p. 27.

${ }^{128}$ Idem, p. 26.

${ }^{129}$ FOUCAULT, Michel; Sécurité, territoire, population; op.cit., p. 3.
} 
diz no começo do curso de 1978 para, no curso do ano seguinte, dizer, no final da primeira aula:

"Eu tinha pensado em lhes dar este ano um curso sobre a biopolítica. Eu vou tentar lhes mostrar como todos os problemas dos quais eu tento me dar conta atualmente, como todos esses problemas têm por nó central, com certeza, esse algo que denominamos a população. Conseqüentemente, é precisamente a partir daí que uma coisa como a biopolítica poderá se formar. Mas, parece-me que a análise da biopolítica não pode ocorrer até que tenhamos compreendido o regime geral dessa razão governamental da qual lhes falo, esse regime que podemos chamar a questão da verdade, primeiramente da verdade econômica no interior da razão governamental, e, conseqüentemente, se se compreende bem do que é que se trata nesse regime que é o liberalismo, que se opõe à razão de Estado, —ou, antes, [a] modifica fundamentalmente sem voltar a pôr em questão os seus fundamentos-, é uma vez que será sabido aquilo que era o regime governamental chamado liberalismo que se poderá, parece-me, capturar aquilo que é a biopolítica." 130

Fica evidente que, ao longo do primeiro, falou-se de algo que não o biopoder; do

mesmo modo, a ressalva expressa na segunda declaração já indica um traço que irá prevalecer ao longo de todo o segundo curso; esse vai acabar por ser exclusivamente uma análise do liberalismo e do neoliberalismo: no começo da oitava aula—de um total de 12—Foucault faz nova referência à biopolítica, mais uma vez em tom de justificação:

"Eu gostaria de assegura-los, apesar de tudo, que eu bem que tinha a intenção, no começo, de lhes falar de biopolítica e então, as coisas sendo como são, eis que eu terminei por lhes falar longamente, e demasiado longamente talvez, sobre o neoliberalismo, e ainda sobre o neoliberalismo sob a sua forma alemã. É preciso contudo que eu me explique um pouco perante vocês por essa, digamos, inflexão na orientação que eu queria dar a este curso." 131

Essa é a última referência ao tema, já que Foucault vai se debruçar, ainda, ao longo dessa e das seguintes aulas do curso, sobre o neoliberalismo norte-americano e francês.

O que é que, afinal, ocorre? Por onde passa a transitar o pensamento de Foucault, o seu interesse, o seu entusiasmo a tal ponto que o tenha levado a "empurrar com a barriga", por dois anos consecutivos, o biopoder, para, em seguida, abandona-lo de todo? A resposta está em Sécurité, territoire, population; mais precisamente na sua

\footnotetext{
${ }^{130}$ FOUCAULT, Michel; Naissance de la biopolitique; Paris, Gallimard-Seuil, 2004, pp. $23-24$.

${ }^{131}$ Idem, p. 191.
} 
quarta aula, no momento em que passa a conceber dois novos conceitos: os conceitos, gêmeos, porventura até siameses, de governamentalidade e de poder pastoral. ${ }^{132}$

\subsubsection{Pastoralidade}

Preocupado com a biopolítica, Foucault começa o curso de 1978 perseguindo a noção de segurança, aventando a possibilidade da existência de um dispositivo de segurança $^{133}$ em nossas sociedades; um dispositivo posterior aos "da lei" e da "disciplina", cujo objeto, mais do que o sujeito de direito ou os corpos, viesse a ser "o

132 A própria seqüência da explicação perante os alunos, acima citada, bem o diz: "Se eu falei tão longamente do neoliberalismo, e ainda pior do neoliberalismo sob a sua forma alemã, entende-se claramente que a razão para tal não era a de que eu quisesse evocar o 'background' histórico ou teórico da democracia cristã alemã. Se eu o fiz não era tampouco para denunciar aquilo que há de não-socialista no governo de Willy Brandt ou de Helmut Schmidt. Se eu me detive um pouco longamente nesse problema do neoliberalismo alemão, foi primordialmente por razões de método, porque eu queria, continuando um pouco aquilo que eu havia começado a lhes dizer o ano passado, ver que conteúdo concreto pode ser dado à análise das relações de poder - sendo ponto passivo, com certeza, e eu o repito ainda mais uma vez, que o poder não pode de modo algum ser considerado nem como princípio em si, nem como um valor explicativo funcionando logo de cara. O termo mesmo poder não faz senão designar um [domínio] de relações que são inteiramente a serem analisadas, e isso que eu propus de chamar a governamentalidade, quer dizer a maneira pela qual se conduz a conduta dos homens, isso não é outra coisa que uma proposição de grade de análise para essas relações de poder.” (Idem, pp. 191-192.)

${ }^{133} \mathrm{O}$ termo, sécurité, poderia ser traduzido por "seguridade", tal como em sécurité sociale, que seria a nossa "seguridade social", bem diferente de "segurança pública”, que, em francês é, também sécurité, só que publique. No caso, tal como usado por Foucault, não diz respeito nem a uma, nem à outra desses acepções: di-lo muito mais à noção, mais geral, de estar ao abrigo de catástrofes " quase naturais", tais como a carestia e catástrofes climáticas ou epidemias - quando entram em ação as equipes da "defesa civil", do corpo de bombeiros. O Conselho de Segurança da ONU, por exemplo, encarregado de tentar evitar e pôr fim a guerras-entre nações-que são hoje capazes de dizimar, em segundos, cidades inteiras, leva em sua denominação uma acepção muito próxima ao significado dado a sécurité por Foucault no âmbito desse curso. Também, hoje, existe um conceito, de "segurança alimentar", e, no caso brasileiro, do seu Conselho respectivo, que cuida especificamente da fome. A partir desses três últimos casos, que giram, todos, em torno da noção de população-ao contrário de "segurança pública", que gira em torno do cidadão e de "seguridade social", que gira em torno de um tipo específico de cidadão-, optamos por "segurança". 
meio" e a população—_uma multiplicidade de indivíduos que são e que só existem profundamente, essencialmente, biologicamente ligados à materialidade no interior da qual eles existem" 134 _ que nele habita. É então que, levantando uma das formas de funcionamento desse dispositivo, relacionada não tanto ao espaço mas a um acontecimento- a carestia $^{135}$ - e às formas que, nos séculos XVII e XVIII, passou a se lidar-deixando o mercado agir livremente—com ela, uma maçã de propriedades newtonianas parece ter-lhe caído na cabeça: é quando surge a noção de "governo" enquanto "condução de condutas"136, ou seja, mais especificamente, a noção de "governamentalidade". Que se deixe a iniciativa, que se a permita agir, como aconselham os fisiocratas em meados do século XVIII: isso não implica necessariamente na ausência de uma gestão das condições que circundam, que rodeiam essa iniciativa, essa "liberdade"; não implica na ausência de uma condução, de um governo, parece descobrir Foucault e essa descoberta vai alterar por completo o rumo do seu presente curso e determinar o do ano seguinte, quando é o tema da liberdade e do Estado—que se diz garantir uma forma de exercício dessa liberdade—que passam a preponderar $^{137}$ sobre o tema de um poder que incide sobre a vida de um conjunto de

\footnotetext{
${ }_{135}^{134}$ FOUCAULT, Michel; Sécurité, territoire..., op. cit., p. 23.

${ }^{135}$ La disette, no original.

${ }^{136}$ Essa noção, além da referência já feita acima a partir do curso de 1979 (cf. nota 132), está no começo da oitava aula de Sécurité, territoire, population e em um texto de 1982 que posfaciou o livro de Dreyfus e Rabinow, Beyond structuralism and hermeneutics ambos nos quais chamam a atenção para o equívoco do termo francês conduite, que quer dizer "ao mesmo tempo o ato de 'mexer' os outros (segundo os mecanismos de coerção mais ou menos estritos) e a maneira de se comportar num campo mais ou menos estreito de possibilidades. O exercício do poder consiste em 'conduzir as condutas' e em conformar as possibilidades. O poder, no fundo, é menos da ordem do afrontamento entre dois adversários, ou do engajamento de um em relação ao outro, que da ordem do 'governo'." (FOUCAULT, Michel; "Le sujet et le pouvoir", op. cit., p. 1056). "Condução de condutas" poderia ser, portanto, em francês, tanto conduction de conduites quanto conduite de conduites.

${ }^{137}$ Ele declara, por exemplo, no final da quarta aula, que seria "mais exato" dar ao curso em andamento o título de "história da governamentalidade" (FOUCAULT, Michel; Sécurité, territoire, population, op. cit., p. 111)
} 
$\operatorname{corpos}^{138}$ —ainda que, como vimos acima, Foucault tenha insistido, ou melhor, tenha

tido dificuldade em abandonar, em largar, como uma criança que tem nas mãos dois

brinquedos para brincar, esse último. Há, nesse momento e a partir dele, nos dois anos

que se seguem, uma retomada da temática do Estado, do Estado-de-Direito e do

pensamento jurídico que o engendrou, uma temática que havia sido abordada em Vigiar

e punir, conforme já vimos; diz ele, no final da segunda aula, ainda fazendo referência

ao termo "dispositivo de segurança"-que passaria a não mais usar, em favor dos

termos "governo", "poder pastoral”, "arte de governar", "governamentalidade"—:

“eu disse em algum lugar ${ }^{139}$ que não se podia compreender a implantação das ideologias e de uma política liberal no século XVIII sem guardar no espírito que esse mesmo século XVIII que tinha tão fortemente reivindicado as liberdades, as havia ainda assim ancorado numa técnica disciplinar que, tomando as crianças, os soldados, os operários lá onde eles estavam, limitava consideravelmente a liberdade e dava, de alguma forma, garantias ao exercício mesmo dessa liberdade. Pois bem, eu acho que eu errei. Não totalmente, certamente, mas enfim, não é exatamente isso. Eu creio que o que está em jogo, é toda uma outra coisa. É que de fato essa liberdade, ideologia e técnica de governo, essa liberdade deve ser compreendida no interior das mutações e transformações das tecnologias de poder. E de um modo mais preciso e particular, a liberdade não é outra coisa senão o correlativo da implantação dos dispositivos de segurança. Um dispositivo de segurança não pode funcionar bem, em todo caso esse do qual eu acabo de lhes falar (sobre a carestia), do que sob a condição que se lhe dê uma coisa que é a liberdade, no sentido moderno [que essa palavra] assume no século XVIII: não mais as franquias e os privilégios que são concedidos a uma pessoa, mas a possibilidade de movimento, deslocamento, processo de circulação de pessoas e de coisas. E é essa liberdade de circulação, no sentido amplo do termo, é essa faculdade de circulação que é necessário compreender, creio eu, pela palavra liberdade, e compreende-la como sendo uma das faces, um dos aspectos, uma das dimensões da implantação do dispositivo de segurança." 140

\footnotetext{
138 "Concretamente, esse poder sobre a vida desenvolveu-se desde o século XVII sob duas formas principais; elas não são antitéticas; elas constituem muito mais dois pólos de desenvolvimento religados por todo um feixe intermediário de relações. Um dos pólos, o primeiro, parece, a formar-se, centrou-se no corpo como máquina: seu adestramento, a otimização das suas capacidades, a extorsão de suas forças, o crescimento paralelo da sua utilidade e de sua docilidade, sua integração a sistemas de controle eficazes e econômicos, tudo isso foi assegurado por procedimentos de poder que caracterizam as disciplinas: anátomo-política do corpo humano. $\mathrm{O}$ segundo, que se formou um pouco mais tarde, por volta de meados do século XVIII, é centrado sobre o corpo espécie, sobre o corpo atravessado pela mecânica do vivente e servindo de suporte aos processos biológicos: a proliferação, os nascimentos e a mortalidade, o nível de sanidade, a duração da vida, a longevidade com todas as condições que podem fazê-la variar; o seu engate se opera por meio de toda uma série de intervenções e de controles reguladores: uma biopolitica da população." (FOUCAULT, Michel; Histoire de la sexualité I..., op. cit., pp. 182-183.)

${ }^{139}$ É bem provável que esse lugar seja Vigiar e punir (cf. infra, nota n ${ }^{\circ} 53$ ).

${ }^{140}$ FOUCAULT, Michel; Sécurité, territoire..., op. cit. p. 50
} 
Subitamente, Foucault parece se dar conta de que esse âmbito que é conhecido como sendo o do poder, esse âmbito marcado pela teoria da soberania, esse âmbito do direito público, onde as noções de Estado e de política se dão as mãos para dizer que o poder (arbitrário) era findo e que a liberdade era agora a protagonista da história, todo esse âmbito do qual ele vinha dizendo que era um âmbito que escondia—sob o manto de uma auto-representação repressora, marcada pelo gládio—o funcionamento de um poder verdadeiro, um poder real, produtor, que servia apenas para mascará-lo, subitamente ele descobre que esse âmbito possui características idênticas—e não mais contrárias-a esse poder produtivo, a diferença residindo numa questão de perspectiva: em que é possível enxergar a existência de um poder que se defina a partir da gestão de liberdades.

A aula de $1^{\circ}$ de fevereiro de 1978, que ficou conhecida, a partir da sua publicação — no mesmo ano em que foi proferida—numa revista italiana, como a aula sobre "A governamentalidade", é o primeiro momento em que Foucault passa a dedicar seus esforços à verificação dessa nova perspectiva. O que é governar? Foucault contrapõe duas visões que respondem a essa questão: a de Maquiavel, que gira em torno da preservação da relação, marcada pela exterioridade, entre um soberano e um determinado território por ele "governado" e a visão de uma série de autores que se contrapõem, fundamentalmente, ao seu Príncipe e que, largamente, podem-tendo esses autores configurado uma "explosão", subseqüente a Maquiavel e que durou até o início do século XIX, do tema da "arte de governar"-sintetizar-se no dizer, de 1555, de um deles, Guillaume de La Perrière, de que "'governo é a correta disposição das coisas, das quais se toma conta para conduzi-las a fim conveniente"”. ${ }^{141}$ Governo-_"paciente", “sábio", “diligente", como receitava, ainda, esse autor, fugindo do uso do gládio-de

${ }^{141}$ Idem p. 101. 
coisas e de homens ${ }^{142}$, visando a sua "correta disposição": eis aí a fórmula de um exercício de poder que chama a atenção de Foucault nesse momento. A esse exercício, ele então dá o nome de governamentalidade, a qual, aprofundando, um pouco mais à frente, ele dá uma outra definição, lapidar: "a condução de condutas". E é essa "condução de condutas" o que o leva a sair do escopo que sempre tinha sido o seu, o da modernidade, para ir se debruçar sobre a primeira forma que esse exercício teve na história do ocidente: o poder pastoral, a idéia, dos primórdios do cristianismo, de pastoralidade. Os cursos de 1978 e 1979, mas principalmente o primeiro, são exemplos nítidos de um pensamento voraz, desejante, apaixonado, marcado, como diria mais à frente, por uma "curiosidade", soberana, inapelável, incorrigível; mas também de um pensamento meticuloso, que se deixa levar, mas que só lentamente, com muita cautela, deixa que conceitos que eram antes empunhados com esperança vão ficando pelo caminho para dar vez a outros mais afiados e cortantes. ${ }^{143}$

Foucault dedica as duas aulas seguintes do curso de 1978 à noção de poder pastoral, mas, antes, diz por que: quer explorar a possibilidade de que, da mesma forma como, ao "adotar o ponto de vista das disciplinas" nos seus estudos anteriores sobre "a doença mental, a delinqüência, a sexualidade", ele tinha procurado

"desvincular as relações de poder em relação à instituição, para analisa-las [sob o ângulo] das tecnologias, desvincula-las também em relação à função, para retoma-las numa

\footnotetext{
142 "Não se governa jamais um Estado, não se governa jamais um território, não se governa jamais uma estrutura política. O que se governa, é de toda forma pessoas, são os homens, são indivíduos ou coletividades. (...) O que se governa, são os homens", esclarece Foucault mais adiante. (Idem, p. 126)

${ }^{143}$ No começo do curso, diz ele que não é nem história, nem economia, nem sociologia aquilo que ele faz, mas "algo que, de uma maneira ou de outra, e por razões simplesmente factuais, tem a ver com a filosofia, isto é, com a política da verdade, pois eu não vejo muito outras definições da palavra 'filosofia' que não essa. Trata-se da política da verdade", para, um pouco mais à frente afirmar que "a dimensão daquilo que está por ser feito, não pode aparecer a não ser, parece-me, que no interior de um campo de forças reais", motivo pelo qual ele evoca um imperativo de trabalho que não seria senão condicional: "se você quer lutar, eis aqui alguns pontos chaves, eis algumas linhas de força, eis algumas fechaduras e algumas barreiras"; trata-se, no fim das contas de "fazer uma análise que será eficaz em termos táticos". (Idem, p. 5)
} 
análise estratégica, e deixa-las livres em relação ao privilégio do objeto, para tentar resituá-las do ponto de vista da constituição dos campos, domínios e objetos de saber" ${ }^{144}$,

algo próximo, no rumo de uma "exterioridade", pudesse ser feito agora, com relação ao

Estado. Em outras palavras—e aí, diz ele, aparece o que está "em jogo" no curso, ou seja, o próprio sentido desse-,

“é possível re-situar o Estado moderno dentro de uma tecnologia geral de poder que teria assegurado as suas mutações, seu desenvolvimento, seu funcionamento? É possível falar que algo como uma 'governamentalidade' que seria para o Estado isso que as técnicas de segregação eram para a psiquiatria, isso que as técnicas de disciplina eram para o sistema penal, isso que a biopolítica era para as instituições médicas?" 145

Uma tecnologia geral de poder, da qual o Estado moderno não seria mais do que o mais recente episódio ${ }^{146}$ : eis aí algo que matiza bastante a afirmação, acima mencionada, de que "o Ocidente tem conhecido, desde a época clássica, uma transformação muito grande dos seus mecanismos de poder" e que nos convida a esse mergulho rumo aos seus primórdios "num Oriente pré-cristão"-fundamentalmente hebraico-_de início, e no Oriente cristão, em seguida.” O que caracteriza o pastorado? Em linhas gerais, diz Foucault, uma relação com a salvação, com a lei e com a verdade: o pastor "guia rumo à salvação, prescreve a lei e ensina a verdade". ${ }^{147}$ A sua arte deriva, descende, da arte e do poder do deus hebraico, que é um deus "que caminha, um Deus que se desloca, um Deus que vagueia" e, assim, seu poder é um que se "exerce essencialmente sobre uma multiplicidade em movimento" ${ }^{\text {"148 }}$, mas que também, na sua

\footnotetext{
${ }^{144}$ Idem, p. 122

${ }^{145}$ Idem, p. 124

146 "E se o Estado não fosse outra coisa que um tipo de governamentalidade?", continua ele a perguntar no final da nona aula, acrescentando: "Se, de fato, todas essas relações de poder que vemos formarem-se pouco a pouco a partir de processos múltiplos e muito diferentes uns dos outros e que pouco a pouco se coagulam e formam efeito, se essas práticas de governo fossem precisamente aquilo a partir do que se constitui o Estado? Teríamos que dizer, a partir desse momento, que o Estado não é na história essa espécie de monstro frio que não parou de crescer e de se desenvolver como uma espécie de organismo ameaçador por cima da sociedade civil. Tratar-se-ia de mostrar como uma sociedade civil, ou melhor tão simplesmente uma sociedade governamentalizada tem, a partir do século XVI, implantado algo, esse algo ao mesmo tempo frágil e obsedante que se chama Estado. Mas o Estado não é senão uma peripécia do governo e não é o governo que é um instrumento do Estado. Ou em todo caso é uma peripécia da governamentalidade." (Idem, p. 253)

${ }_{147}$ Idem, p. 170.

${ }^{148}$ Idem, p. 129.
} 
versão cristã, funciona operando "uma economia sutil do mérito e do demérito" "149 que estabelece uma "obediência pura" como "princípio de conduta unitária"150, algo bem diferente do deus e do magistrado (ou rei) gregos, cujos poderes se exercem sobre uma cidade, sobre um templo, no primeiro caso, ou, no segundo, sobre um território e à maneira do tecelão—e aí a referência a A política, de Platão—:

"não algo que se ocupa globalmente do todo, como o pastor é suposto se ocupar de todo o rebanho. A política, como a arte do tecelão, não pode se desenvolver a não ser que a partir e com a ajuda de um certo número de ações adjuvantes ou preparatórias. É preciso que a lã tenha sido tosada, é preciso que o fio tenha sido trançado, é preciso que o cardador tenha passado por lá para que o tecelão possa operar. Do mesmo modo, vai ser preciso, para assistir ao homem político, toda uma série de artes adjuvantes. Fazer a guerra, dar boas sentenças nos tribunais, persuadir também as assembléias pela arte da retórica, tudo isso, não é propriamente a arte da política, mas é a condição do seu exercício. Qual vai ser então a atividade política propriamente dita, a essência do político, o homem político, ou antes, a ação do homem político? Vai ser a de ligar, como o tecelão liga a urdidura e a trama." 151

A arte do pastor é uma arte que gere um fluxo, que pressupõe um todo que se movimenta, e o pastor é aquele que, conhecedor da verdade e enunciador da lei, vai conduzir esse fluxo e cada um dos seus componentes, que lhe devem obediência pessoal, para longe dos perigos, rumo às pastagens tranqüilas da salvação. Como isso pode estar relacionado com o Estado moderno? Bom, é isso que Foucault vai mostrar, num percurso que vai do século XVI até os dias, neoliberais, atuais.

A história dessa técnica—pastoral—de poder teria sido uma história marcada por uma continuidade? Teriam os governantes, no Ocidente, sempre tido o modelo do pastor como o seu modelo, dentro de uma espécie de dinastia secreta, à la Código da Vinci? Nada disso: o poder pastoral, a governamentalidade, essa noção de que cabe a

149 Idem, p. 176. Um texto importante sobre a especificidade do poder pastoral é uma conferência proferida por Foucault em 1979, "Omnes et singulatim", onde é abordada justamente essa qualidade de, ao mesmo tempo em que se trata de salvar a todos, a todos em seu conjunto, "trata-se de uma questão de zelo (bienveillance) constante, individualizado e final” (FOUCAULT, Michel; “'Omnes et singulatim': vers un critique de la raison politique", in $D E I I$, texto $\mathrm{n}^{\circ} 291, \mathrm{p}$. 957), totalizando e individualizando simultaneamente.

${ }^{150}$ FOUCAULT, Michel; Sécurité, territoire, population, op. cit., p. 177.

${ }^{151}$ Idem, p. 149. 
alguém conduzir o rebanho e as suas condutas, ou almas, rumo à salvação, é uma tecnologia específica de poder que se dá no contexto religioso hebraico, que reaparece na pastoral cristã das almas do início de nossa era e que irá "explodir" num contexto especificamente político em meados do século XVI, inaugurando aquilo que Foucault chama de "era das condutas". Nessa época, diz Foucault, "o problema de conduzir e conduzir-se como problema fundamental", passa a apresentar "uma forma não especificamente religiosa ou eclesiástica", a assumir uma forma pública—ainda que “essa oposição do privado e do público não é ainda bem pertinente, apesar de que é sem dúvida na especificação das diferentes formas de conduta que a oposição do público e do privado começa a se constituir nessa mesma época". E o que isso significa? Bem, que

“em todo caso, no domínio público, no domínio que mais tarde se denominará político, aparece também o problema: como, em que medida o exercício do poder soberano pode e deve se ancorar num certo número de tarefas que não lhe eram até o momento reconhecidas como sendo suas e que são justamente as tarefas de condução? O soberano que reina, o soberano que exerce sua soberania se vê, a partir desse momento, encarregado, confiado, designado a novas tarefas, e essas novas tarefas são aquelas precisamente da condução das almas." 152

Nasce o Estado, como resposta a essa necessidade, a essa tarefa, ou incumbência imposta pelo exercício de uma tecnologia de poder, já velha, que muta; e, claro, junto com ele uma racionalidade que lhe é específica, que carrega a sua verdade: a razão de Estado. Exemplo disso, um dos primeiros: um tratado como o de Giovanni Botero, do fim do século XVI, Della ragione di stato libri dieci, onde o Estado é definido como "uma firme dominação sobre as pessoas" e a sua "razão" como "o conhecimento dos meios próprios a fundar, a conservar e a aumentar essa dominação" ${ }^{153}$. Foucault narra, então, como se deu o gradual surgimento de um novo domínio, de um novo campo do

\footnotetext{
${ }^{152}$ Idem, p. 236.
}

${ }^{153}$ Idem, p. 243. 
"saber", um domínio que nos é, já, familiar, desde os tempos em que se falava dos

“intelectuais e o poder”: o domínio do político. Diz ele:

“a palavra 'político', [de início], vocês o notaram, é sempre (nessa época, século XVI) empregada de modo negativo, e [em seguida] 'político' não se refere a uma coisa, a um domínio, a um tipo de prática, mas a pessoas. São 'os políticos'. Os políticos, eis uma seita, ou seja, algo que cheira ou que beira a heresia. A palavra 'político' aparece aqui, portanto, para designar pessoas que compartilham entre si uma certa maneira de pensar, uma certa maneira de analisar, de razoar, de calcular, uma certa maneira de conceber aquilo que um governo deve fazer e sobre que forma de racionalidade se deve apoiá-lo. Dito de outro modo, o que apareceu logo no Ocidente dos séculos XVI e XVII, não é a política como domínio, não é a política como conjunto de objetos, não é nem mesmo a política como profissão ou como vocação, são os políticos, ou, se quiserem, é uma certa maneira de colocar, de pensar, de programar a especificidade do governo em relação ao exercício da soberania. Por oposição ao problema jurídico-teológico do fundamento da soberania, os políticos, são esses que vão tentar pensar por ela própria a forma da racionalidade do governo. E [é] simplesmente no meio do século XVII que vocês vêem aparecer a política, a política entendida então como domínio ou como tipo de ação. A palavra 'política', vocês a encontram num certo número de textos, em particular no marquês de Chastelet, vocês a encontram também em Bossuet. E no instante em que Bossuet fala da "política tirada da santa Escritura", vocês vêem que nesse momento a política, com certeza, deixou de ser uma heresia. A política deixou de ser uma maneira de pensar própria a certos indivíduos, uma certa maneira de razoar própria a certos indivíduos. Ela bem se tornou um domínio, um domínio valorizado de uma forma positiva na medida em que terá sido candidamente integrada no nível das instituições, no nível das práticas, no nível dos modos de fazer, no interior do sistema de soberania da monarquia absoluta francesa. Luis XIV, eis precisamente o homem que fez a razão de Estado entrar com a sua especificidade nas formas gerais da soberania. (...) quando ele diz 'o Estado sou eu', é precisamente essa costura soberania-governo que é posta em marcha." 154

Por um estranho caminho, talvez até mesmo sem se dar conta de imediato,

Foucault está de volta àquilo que, anterior e posteriormente, declarou ser aquilo que ele

fazia, aquilo que "afinal de contas (é) aquilo a que eu tenho querido me aferrar há tempos": "uma iniciativa para evidenciar alguns dos elementos que poderiam servir a uma história da verdade"155 —e não mais a história de "uma verdade", o biopoder. Este, ao contrário da "razão de Estado", nunca se apresentou, claramente, à luz do dia, como um saber, como um saber verdadeiro, necessário para todo aquele que esteja incumbido do ato de governar. Pois é bem isto o que esta é: um conhecimento “necessário", necessário à salvação do próprio Estado e daqueles que fazem parte dele,

${ }^{154}$ Idem, pp. 251-152.

${ }^{155}$ FOUCAULT, Michel; Histoire de la sexualité, vol II..., op. cit., p. 13. 
um conhecimento que não se resume, de modo algum, a um conhecimento das leis—-tal

como fica claro quando se examina a noção de "golpe de Estado" como algo que não

lhe é nem "estranho", nem "excepcional”. Nesse sentido, diz Foucault:

\begin{abstract}
"o que o soberano ou aquele que governa, o soberano enquanto governa, deve conhecer, não são simplesmente as leis, não são nem mesmo primeiramente nem fundamentalmente as leis (ainda que sempre se faça referência a elas, certamente, e que seja necessário conhece-las), mas o que é, eu creio, ao mesmo tempo novo, capital e determinante, é que o soberano deve conhecer esses elementos que constituem o Estado, no sentido em que (Giovanni Antonio) Palazzo, no texto pelo qual eu comecei (trata-se de Discorso del governo e della ragion vera di Stato, de 1604), falava do Estado. Isto é, é preciso que aquele que governa conheça os elementos que vão permitir a manutenção do Estado, a manutenção do Estado em sua força ou o desenvolvimento necessário da força do Estado, para que ele não seja dominado pelos outros e não perca a sua existência ao perder a sua força ou sua força relativa. Quer dizer que o conhecimento necessário ao soberano será um conhecimento das coisas mais que um conhecimento da lei, e essas coisas que o soberano deve conhecer, essas coisas que são a realidade mesmo do Estado, é isso precisamente o que se chama à época a 'estatística'. A estatística, etimologicamente, é o conhecimento do Estado, o conhecimento das forças e dos recursos que caracterizam um Estado em um dado momento" 156 ,
\end{abstract}

em grande parte repetindo o que havia dito um pouco antes, evidenciando que o que se trata, nesse discurso, é de salvação e de necessidade—e onde há "necessidade", há

"verdade", mais do que convenção, criação-:

“...a razão de Estado em si, e eis um ponto essencial a ter em conta, a razão de Estado em si não é absolutamente homogênea a um sistema de legalidade ou de legitimidade. (...) A razão de Estado é de todo modo fundamental com relação a essas leis, mas no seu jogo ordinário ela faz uso delas, porque precisamente ela o estima necessário ou útil. Mas vai haver momentos em que a razão de Estado não pode mais se servir dessas leis, e onde ela é obrigada por algum acontecimento premente e urgente, em função de uma certa necessidade, de se livrar dessas leis. Em nome de quê? Em nome da salvação do Estado. É essa necessidade do Estado com relação a si mesmo que vai, a certa altura, levar a razão de Estado a suprimir as leis civis, morais, naturais que ela bem quis reconhecer e dentro da qual ela tinha feito, até então, o seu jogo. (...) O golpe de Estado, diz (Gabriel) Naudé (em Considérations politiques sur les coups d'État, de 1667), obedece a 'uma justiça artificial, particular, política, [...] relacionada à necessidade de Estado'. A política, por conseguinte, não é algo a ser inscrito no interior de uma legalidade ou de um sistema de leis. A política tem a ver com algo outro, mesmo se ela utiliza as leis como instrumento quando ela delas precisa em certos momentos. A política é algo que se relaciona com a necessidade." 157

Naissance de la biopolitique, o curso do ano seguinte, vai seguir o mesmo caminho, avançando, na descrição dessa mistura de salvação, verdade e lei, até os dias

${ }^{156}$ FOUCAULT, Michel; Sécurité, territoire, population, op. cit., pp. 279-280.

${ }^{157}$ Idem, p. 267-269. 
atuais. A razão de Estado continua a ser uma das formas assumidas por essa tecnologia de poder que é a governamentalidade, a condução das condutas ${ }^{158}$; mas não é a única: o século XIX vê nascer uma crítica a esse tipo de exercício, mas uma crítica que vai somente apresentar novas medidas, novos metros, novos diapasões para essa "verdade" da "política": o mercado, a sociedade civil ${ }^{159}$. O princípio, de que se deve gerir as condutas por meio de um conhecimento—-desta feita não das "forças" que compõem o Estado, berço da "estatística", nelas intervindo, mas da "correta", "apropriada" e eficaz $^{160}$ disposição das condições que cercam o mercado e a sociedade civil—que será o único capaz-o necessário, portanto—de livrar os homens e mulheres, que compõem um Estado, do desastre-o único capaz de salva-los, portanto—- eis algo que se mantém incólume. Os economistas, tal qual os "políticos" dos séculos XVI e XVII que começaram como uma categoria próxima à dos hereges, vão lentamente entrar em cena, pular no palco, para se tornarem os protagonistas da política, como conhecedores de uma "natureza" das coisas que envolvem o mercado e a sociedade: "é assim, por exemplo, que é uma lei da natureza, explicarão os economistas, que a população, por

${ }^{158}$ Recentemente houve toda uma polêmica no Brasil em torno dos números relativos ao Produto Interno Bruto (PIB), cuja divulgação pelo IBGE teria sido adiada-dado que não eram tão positivos-pelo governo federal. Largamente, isso ocorreu porque se defende que esses números são parte de algo que extrapola a governança do poder executivo, ainda que sejam produzidos por um instituto vinculado a ela. Esses números são do Estado, mais do que do governo; estão, de certa forma, acima dele. São elementos fundamentais, em verdade, de uma razão de Estado, do exercício de uma racionalidade governamental que é nutrida, inclusive, pela própria imprensa, que lhes dá destaque, às vezes maior do que dá a realizações de governo propriamente ditas, como, por exemplo, a redistribuição da renda. Igualmente, é possível pensar no papel das agências de inteligência de alguns países ocidentais, as quais operam o quê, senão uma razão que não se atêm às meras leis, sejam nacionais ou internacionais? São exemplos da permanência dessa racionalidade, que Foucault localiza como tendo o seu início no final do século XVI.

${ }^{159}$ Foucault dá a essa crítica o nome de "racionalidade governamental crítica" e diz que ela consiste não numa objeção ao "abuso da soberania", mas ao "excesso de governo. E é ao excesso de governo, ou à delimitação em todo caso do que seria excessivo para um governo, que se poderá medir a racionalidade da prática governamental." (FOUCAULT, Michel; Naissance de la biopolitique, op. cit. p. 15)

160 O poder público no Ocidente, diz Foucault, passa a girar em torno do princípio da utilidade: "É bem o problema da utilidade, da utilidade individual e coletiva, da utilidade de cada um e de todos, da utilidade dos indivíduos e da utilidade geral, é esse problema aí que vai finalmente ser o grande critério dos limites do poder público e de formação de um poder público e de um direito administrativo. Entrou-se, desde o século XIX, numa era onde a utilidade recobre cada vez mais todos os problemas tradicionais do direito." (Idem, p. 45.) 
exemplo, se desloque rumo aos salários mais elevados; é uma lei da natureza que faz com que tal tarifa alfandegária protetora dos altos preços de subsistência traga consigo algo como uma carestia"161 , diz Foucault. Se "salvação" há, esta há de passar por eles. Se há lei, também: ela terá que se adequar ao que eles dizem. Esse é o liberalismo, mais uma forma de exercício da governamentalidade-uma forma que, por sinal, sofreu os seus re-arranjos, como narra Foucault a propósito da necessidade da introdução da noção de "sociedade civil"162, como o lugar que aloja um homem , o oeconomicus, novo, o "homem do interesse""163.

Para além da compreensão que permite da atualidade política—com a discussão que promove a respeito de práticas e teorias liberais, como as políticas de renda mínima, a teoria do capital humano e o papel novo que o direito passa a assumir quando a lei se torna mais e mais formal, limitadora da intervenção administrativa—o que esse curso tem de mais importante é a consciência—e a confirmação dela—de que não há nada que escape à leitura do poder enquanto exercício, enquanto tecnologia, uma leitura que ${ }^{161}$ Idem, p. 19.

162 "A sociedade civil não é uma realidade primeira e imediata. A sociedade civil é uma coisa que faz parte da tecnologia governamental moderna. Dizer que [ela] faz parte dela, não quer dizer que ela é produto dela pura e simplesmente, como tampouco quer dizer que ela não tenha realidade. A sociedade civil é como a loucura, é como a sexualidade. É isso o que eu chamaria realidades de transação, isto é, que é precisamente no jogo tanto das relações de poder como daquilo que a elas escapa, é daí que nascem, de alguma forma na interface entre governantes e governados, essas figuras transacionais e transitórias que, por não terem existido desde sempre, não são menos reais e que podemos chamar, de acordo com o caso, a sociedade civil, de resto a loucura, etc.. Sociedade civil, portanto, como elemento de realidade transacional dentro da história das tecnologias governamentais, realidade transacional que me parece deveras correlativa a essa forma de tecnologia governamental que chamamos o liberalismo, isto é, uma tecnologia que governo que tem como objetivo a sua própria auto-limitação na medida mesma em que é indexada à especificidade dos processos econômicos." (Idem, pp. 300-301)

${ }^{163}$ Aquele que, ao soberano, "detentor de direitos e fundador do direito positivo a partir do direito natural dos indivíduos", diz: "tu não deves, não porque eu tenho direitos e tu não tens o direito de tocá-los-isso é o que diz o homem de direito, é o que diz o homo juridicus ao soberano: eu tenho direitos dos quais eu te confiei alguns, você não pode tocar os outros, ou: eu te confiei meus direitos para tais e tais fins. $\mathrm{O}$ homo oeconomucus não diz isso. Ele diz também ao soberano: você não deve, mas ele diz ao soberano: você não deve, por que? Você não deve porque você não pode. E você não pode no sentido de 'você é impotente' e por que você é impotente, por que você não pode? Você não pode porque você não sabe e você não sabe porque você não pode saber." (Idem, p. 286) A noção de sociedade civil seria o que teria evitado, segundo Foucault, que "a arte de governar" se cindisse em dois ramos: o jurídico e o econômico. (cf. Idem, p. 299) 
Foucault vinha promovendo desde sempre, desde o seu estudo sobre a loucura; nem mesmo o Estado, essa construção que se apresentava como algo tão próximo de uma tentativa de regulação do poder, de diluição dele ou de acerto de contas com ele em nome de uma liberdade. Esse Estado, então, deixa de ter as características que o apresentam como um "monstro frio"164 e passa a ser visto como uma tecnologia em que a liberdade, mais do que um objetivo a ser alcançado ou garantido é uma espécie de matéria-prima: ele não é nada além do que

"o efeito, o perfil, o corte móvel de uma perpétua estatização, ou de perpétuas estatizações, de transações incessantes que modificam, que deslocam, que embaralham, que fazem deslizar insidiosamente, pouco importa, as fontes de financiamento, as modalidades de investimento, os centros de decisão, as formas e os tipos de controle, as relações entre poderes locais, autoridade central, etc. Em suma, o Estado não tem entranhas, sabe-se-o bem, não simplesmente nisso de que ele não terá sentimentos, nem bons nem ruins, mas ele não tem entranhas no sentido de que ele não tem interior. $O$ Estado não é nada mais que o efeito móvel de um regime de governamentalidades múltiplas." 165

E a liberdade, essa que esse "monstro frio" teria por objetivo resguardar? Bom, essa, diz Foucault, não passa, "mas já é muito", de "uma relação atual entre governantes e governados, uma relação na qual a medida do 'demasiado pouco' de liberdade que existe é dada pelo 'mais ainda' de liberdade que é reivindicada" ${ }^{166}$, ou seja, uma relação que se define, diariamente, localmente, particularmente, a partir do poder, se define nele, e não, abstratamente, teoricamente, contra ou apesar dele. E essa liberdade de movimento, de iniciativa, que o Estado de Direito garante? Bom essa não é nada mais do que uma matéria prima dessa mais recente versão da condução de condutas, o liberalismo, dessa prática "consumidora de liberdade", que tem no seu interior uma

164 Essa expressão, que já havia aparecido em Sécurité, territoir, population, aparece no início de Naissance de la biopolitique, quando Foucault diz que tentou mostrar, no ano anterior, que "o Estado, longe de ser uma espécie de dado histórico-natural que se desenvolveria por seu próprio dinamismo como um 'monstro frio' cuja semente teria sido lançado em um determinado momento da história e que, aos poucos, a iria consumindo, o Estado não é isso, o Estado não é um monstro frio, é o correlativo de uma certa forma de governar." (Idem, p. 7)

${ }^{165}$ Idem, p. 79.

${ }^{166}$ Idem, p. 64. 
"obrigação" de produzir e de organizar liberdade; é uma liberdade falsa, ilusória, posto que

"se esse liberalismo não é tanto assim o imperativo da liberdade quanto a gestão e a organização das condições nas quais se pode ser livre, vocês vêem bem que se instaura, no coração mesmo dessa prática liberal, uma relação problemática, sempre diferente, sempre móvel entre a produção da liberdade e aquilo mesmo que, produzindo-a, corre o risco de limita-la e de destruí-la." 167

O que há de mais importante nesse curso de 1979 é que Foucault passa a perceber que é possível falar em liberdade em termos que não são aqueles que fazem parte de todo o discurso—-seja ele dos juristas do passado ou do presente, seja dos intelectuais, seja dos defensores de uma razão de Estado, ou dos que, economistas, querem a sua limitaçãoque concebe o Estado como uma necessidade. $\mathrm{E}$ isso, é o conceito de governamentalidade que permite. Como?

A análise dos procedimentos de governamentalidade, diz Foucault no começo da oitava aula de Naissance de la biopolitique, assim como a análise do micro-poderes, “deve ser encarada como simplesmente um ponto de vista, um método de decifração que pode ser válido para toda a escala (de fenômenos de condução de condutas), qualquer que seja a sua grandeza." Aquilo que ele tinha feito com relação à conduta dos loucos, dos doentes, dos delinqüentes, das crianças, a utilização dessa "grade da governamentalidade", ele se dá conta de que é possível fazer com o Estado; que a utilização dessa "grade" "pode valer, igualmente, no momento em que se trata de abordar fenômenos de uma escala inteiramente outra, como por exemplo uma política econômica, como a gestão de todo um corpo social." "A análise dos micro-poderes", conclui, "não é uma questão de escala, não é uma questão de setor, é uma questão de

${ }^{167}$ Idem, p. 65. 
ponto de vista."168 A condução de condutas, esse ponto de vista, permite que vejamos que há, ao longo de todo o tecido social, jogos sendo jogados entre governantes e governados. São, dir-se-á, jogos de poder-são os "micro-poderes" em exercício em todos os âmbitos ou setores, inclusive os "macro"-, mas, ao mesmo tempo, são jogos em que o que está em jogo é uma possibilidade, a possibilidade da liberdade. Assim, ficam claras as palavras de Foucault quando, em 1982, ele diz que o poder, as relações de poder, implicam num "agonismo" em que, "no coração da relação de poder, 'provocando-a' sem cessar, está a recalcitrância do querer e a intransitividade da liberdade" "169, ou, numa entrevista de 1984, de que elas são um "jogo estratégico entre liberdades"170. A governamentalidade, diz ele nessa última,

"implica a relação de si a si, o que quer dizer justamente que, nessa noção de governamentalidade, eu busco o conjunto de práticas pelas quais pode-se constituir, definir, organizar, instrumentalizar as estratégias que os indivíduos, na sua liberdade, podem ter uns em relação aos outros. São indivíduos livres que tentam controlar, determinar, delimitar a liberdade dos outros e, para tanto, eles dispõem de certos instrumentos para governar os outros. Isso repousa portanto bem sobre a liberdade, sobre a relação de si a si e a relação com o outro. Ao passo que se você tentar analisar o poder não a partir da liberdade, das estratégias e da governamentalidade, mas a partir da instituição política, você não pode vislumbrar o sujeito mais do que como sujeito de direito. Tem-se um sujeito que era dotado de direitos ou que não o era e que, pela instituição da sociedade política, recebeu ou perdeu direitos: por esse caminho, é-se remetido a uma concepção jurídica do sujeito. Em compensação, a noção de governamentalidade permite, eu creio, fazer valer a liberdade do sujeito e a relação aos outros, isto é, aquilo que constitui a matéria mesma da ética."171

\footnotetext{
${ }^{168}$ Idem, p. 192.

${ }^{169}$ FOUCAULT, Michel; "Le sujet et le pouvoir”, in DE II, op. cit., p. 1057. Na continuação, ele explica melhor o termo: "muito mais do que um 'antagonismo' essencial, valeria mais falar de um 'agonismo'de uma relação que é ao mesmo tempo de incitação recíproca e de luta; menos de uma oposição termo a termo que as bloqueia uma em face à outra do que de uma provocação permanente." (Idem, ibid.)

${ }^{170}$ FOUCAULT, Michel; "L'éthique du souci de soi comme pratique de liberté", in $D E I I$, texto $\mathrm{n}^{\circ} 356$, p. 1547.

${ }^{171}$ Idem, pp. 1547-1548.
} 


\section{Parte II: Uma outra perspectiva}

Viu-se, no capítulo anterior, que o poder foi um tema ao qual Foucault se dedicou quase que por obrigação, não por "vocação", um desvio necessário, no qual se deparou com essa figura tão afeita—ainda que o negue de "pés juntos"—a ele (o poder): o intelectual que carrega consigo a promessa de deter a verdade da política. "Se eu fui levado a falar diversas vezes dessa questão do poder", diz ele na mesma entrevista de 1983 em que afirma peremptoriamente que não é um teórico do $\operatorname{poder}^{172}$ —e diante de uma questão relativa à sua "microfísica do poder"-,

“é na medida em que a análise política que era dada dos fenômenos políticos não me parecia poder dar conta desses fenômenos mais finos e mais detalhados que eu quero evocar, quando eu coloco a questão do dizer verdadeiro sobre si mesmo. Se eu digo verdade sobre mim mesmo tal como o faço, é que em parte, eu me construo como sujeito através de um certo número de relações de poder que são exercidas sobre mim e que eu exerço sobre os outros. Isso para situar o que é para mim a questão do poder. Para retornar à questão que você acaba de evocar, eu não vejo muito bem onde está a objeção. Eu não faço uma teoria do poder. Eu faço a história, num dado momento, da maneira pela qual são estabelecidas a reflexividade de si sobre si e o discurso de verdade que lhe é ligado"173,

sendo que, a essa altura, já estava claro para ele que seu problema "não cessou nunca de ser a verdade, o dizer verdadeiro, o wahr-sagen — aquilo que é esse dizer verdadeiro-e a relação entre dizer verdadeiro e formas de reflexividade, reflexividade de si sobre si”"174; ou seja, já havia surgido nele a clareza a respeito da noção de um sujeito, ou de uma subjetividade, que está sempre em relação a um dizer que quer sobre ele governar $^{175}$. Esse, o sujeito na sua relação com o dizer verdadeiro e as possibilidades

\footnotetext{
${ }^{172}$ Cf. infra, nota $\mathrm{n}^{\mathrm{o}} 11$.

${ }^{173}$ FOUCAULT, Michel; "Structuralisme et postructuralisme", in DE II, texto no 330, p. 1270.

${ }^{174}$ Idem, p. 1264.

175 Novamente, reforçando o que disse na entrevista de 1983, em 1984 Foucault inicia uma outra dizendo, diante de uma pergunta a respeito da sua atual andança filosófica em que se percebia um apego ao tema da subjetividade e da verdade_-aliás esse é o nome do seu curso no de 1981 no Collège de France-, que
} 
que surgem a partir dessa definição, será o tema da última parte desta tese. O que importa ver, por ora, é que a crítica aos intelectuais e à noção de poder como repressão-que eles, os intelectuais, tanto no seu feitio defensor do Estado de direito, quanto no que decorre de uma crítica deste, baseada no conceito de ideologia, propugnam-foi capaz de gerar, com a concepção do poder enquanto “jogo estratégico entre liberdades" - acima apontada — que dela decorre, uma nova perspectiva a respeito da política e do direito. Uma perspectiva em que a ênfase recai sobre a ética e sobre a liberdade_-“o que é a ética senão a prática da liberdade, a prática refletida da liberdade?", pergunta ele, para, em seguida afirmar que essa última, a liberdade, é “a condição ontológica" da primeira, aquilo que "toma forma" naquela, quando refletida ${ }^{176}$ —, essa palavra, já tão surrada pelos séculos, que os homens, na política e no direito, têm se empenhado ${ }^{177}$ em tornar realidade e que nos dias atuais se encontra presa a uma concepção que a quer muito bem delimitada, posto que, reconhece-se, ela é perigosa.

Ver-se-á, também, logo depois, que implicações a introdução do conceito de governamentalidade teve no que diz respeito à concepção nova que Foucault passou a ter sobre dois filósofos que ele havia anteriormente combatido: Kant e Platão. Filósofos da liberdade e da atitude crítica—-da diferença, mais do que da razão e do Mesmo—,

\footnotetext{
"na realidade, esse foi sempre o meu problema, mesmo se eu formulei de um modo um pouco diferente o enquadramento dessa reflexão. Eu procurei saber como o sujeito humano entrava em jogos de verdade, queira que esses jogos de verdade tenham a forma de uma ciência ou que se refiram a um modelo científico, ou os jogos de verdade como aqueles que se pode encontrar em instituições ou práticas de controle." (FOUCAULT, Michel; "L'éthique du souci de soi comme pratique de liberté", op. cit., p. 1528)

${ }^{176}$ Idem, pp. 1550-1551.

${ }^{177}$ Poder-se-ia dizer que a busca de uma liberdade é o que move a política. Mas, se assim for, vê-se que hoje há uma crise nesse modelo, pois séculos de "política" parecem ter redundado em uma falta de opções "viáveis" que, inclusive, autorizam alguns pensadores a falar em um "fim da história". Mas, ao mesmo tempo, na visão de Foucault, é uma tarefa para o filósofo, pois como ele diz na nota fúnebre de 1979 a respeito do seu amigo Maurice Clavel,: "como todo bom filósofo, aquilo com o que ele mexia, era a liberdade." (FOUCAULT, Michel; "Vivre autrement le temps", in DE II, texto n' 268, p. 789)
} 
eles passaram, com a temática do governo de si-tão clara em Platão e tão evidente na busca de uma maioridade na aposta iluminista de Kant-, a ser os dois principais interlocutores de Foucault—como se ele tivesse finalmente conseguido sair da sombra de Nietzsche, ir além dele—, nos seus últimos seis anos de vida. 


\subsection{Capítulo 3: Política, Liberdade e Direito}

\subsubsection{A periculosidade da liberdade}

São diversos os momentos em que Foucault, nas entrevistas que concedeu, é instado a falar sobre política, sobre a sua relação com isso ao que é dado o nome de política. Já foi visto acima, por exemplo, um momento-a entrevista com Trombadori-em que faz um acerto de contas com o comunismo tal como expresso na forma dos seus partidos europeus, e em que medida esse acerto depende da sua concepção a respeito do $\operatorname{poder}^{178}$. Contudo, o que ele tinha a dizer e disse sobre a política contemporânea não se resumiu, de forma alguma, ao comunismo real e/ou partidário. Isso seria, por demais, fácil: a própria realidade mundial se encarregava de tornar evidente a falência desse modelo. Muito mais, se havia algo na política contemporânea que o instigava, esse algo estava do lado do modelo disso que é chamado de um Estado liberal de direito, erguido sobre a idéia de representação; de representação política. Foucault percebia que esse modelo baseava-se em instituições, garantidoras, dizia-se, desse bem, a liberdade, farol a guiar os passos de qualquer um que resolvesse envolver-se com a representação dos outros. E percebia, igualmente, que essas instituições promoviam justamente o contrário daquilo para o qual, dizia-se, foram

\footnotetext{
${ }^{178}$ Cf. infra, notas n ${ }^{\circ} 59$ e 60.
} 
criadas. Daí que, para ele, esse outro modelo, também, se apresentava como um modelo

falido. Com ironia diz, então, quando indagado, em 1984, a respeito de qual seria, afinal, a sua classificação no campo da política—-um idealista, um niilista, um 'nouveau philosophe', um antimarxista, um novo conservador...?”-

"É verdade que eu não gosto de me identificar e que me diverte a diversidade de julgamentos e de classificações de que fui objeto. Algo me diz que deveriam finalmente ter-me achado um lugar mais ou menos aproximativo após tantos esforços em direções tão variadas; e como eu não posso evidentemente pôr em questão a competência daqueles que se confundem em seus julgamentos divergentes, como não é possível pôr em causa sua distração e sua tomada de partido, é necessário decidir-se a ver, na sua incapacidade em me situar, algo que decorre de mim. (...) E que concerne sem dúvida fundamentalmente à minha forma de abordar as questões da política. É verdade que a minha atitude não diz respeito a essa forma de crítica que, sob o pretexto de um exame metódico, recusaria todas as soluções possíveis, salvo uma que seria a boa. Ela é muito mais da ordem da problematização: isto é da elaboração de um domínio de fatos, de práticas e de pensamentos que me parecem colocar problemas à política. Eu não penso, por exemplo, que haja qualquer 'política' que possa a respeito da loucura ou da doença mental deter a solução justa e definitiva. Mas eu penso que há, na loucura, na alienação, nos problemas de comportamento, razões para interrogar a política: e a essas questões a política deve responder, mas ela não responderá jamais totalmente. Da mesma forma para o crime e a punição: será falso, naturalmente, imaginar-se que a política não tem nada a ver com a prevenção do crime e do seu castigo, portanto nada a ver com um certo número de elementos que modificam sua forma, seu sentido, sua frequiência, mas será igualmente falso pensar que há uma forma política que seja capaz de resolver a questão do crime e de lhe pôr um termo." 179

O problema da política, portanto, estava na totalização que ela necessariamente

promovia, ou melhor, no modelo totalizador que ela usava, sempre com a necessidade

de definir uma proposta que estaria em oposição a outras e que seria capaz de eliminar,

de uma vez por todas, as dificuldades. Esse é o jogo-que pretende ser o próprio "exercício da liberdade"-da política: a "vida política" a ele se resume , sendo que as instituições que viabilizam aquilo que resulta desse jogo, caso vistas no seu funcionamento real, não fazem senão aprofundar uma não-liberdade, através de tecnologias, de formas de exercício de poder, cada vez mais precisas e eficazes, como a disciplina. Foucault então declara que aquilo que lhe interessa "é mais a moral do que a

${ }^{179}$ FOUCAULT, Michel; "Polémique, politique et problématisations", in $D E I I$, texto $\mathrm{n}^{\text {o }} 342$, pp. 14121413. 
política, ou em todo caso, a política como uma ética". Somente assim poder-se-ia, na política, escapar ao jogo da totalização: "abrindo" problemas "tão concretos e gerais quanto possível-problemas que tomam a política pelo avesso, atravessam as sociedades em diagonal e são ao mesmo tempo constituintes de nossa história e constituídos por ela." ${ }^{\prime 180}$

Certamente, um dos momentos cruciais para a clareza que Foucault passou a ter a respeito dessa concepção da política foi quando começou a se dar conta que a distinção entre Estado e sociedade civil-aquela distinção que institui o discurso da política como sendo o "cuidado com a coisa pública", o discurso republicano-, como diz a Trombadori, é "pouco fecunda", até mesmo enganosa. Diz ele a respeito:

"uma das razões que me levam a levantar a questão do poder capturando-o de certa maneira no seu meio, lá onde ele se exerce, sem procurar nem as suas formulações gerais nem seus fundamentos, é que eu recuso a oposição entre um Estado que seria detentor do poder e que exerceria sua soberania sobre a sociedade civil, a qual, em si, não seria depositária de semelhantes processos de poder. Minha hipótese é que a oposição entre Estado e sociedade civil não é pertinente." 181

Essa percepção ensejaria em sua obra, para alguns interlocutores seus, historiadores, numa mesa redonda ocorrida em 1978, aquilo a que deram o nome de "efeito anestesiante". Livros como Vigiar e punir, dizem eles, para os educadores e agentes penitenciários, carregariam consigo "uma implacabilidade da qual eles não conseguem sair"-muito na linha de um Baudrillard, que advoga a necessidade de "esquecer Foucault". Esses interlocutores invocam a posição de historiadores que se recusariam a aceitar "o famoso "esquema foucauldiano"” (de denúncia das relações de poder, de tudo medir a partir delas) em função, também, desse "efeito". A eles, Foucault responde dizendo que

"têm me parecido, esses historiadores, muito mais 'estesiados', 'irritados'—no sentido de Broussais, bem entendido.(...) Irritados por quê? Por um esquema? Não penso, pois

${ }^{180}$ FOUCAULT, Michel; "Politique et éthique: une interview", in DE II, texto no 341, pp. 1405-1406.

${ }^{181}$ FOUCAULT, Michel; "Entretien avec Michel Foucault”, op. cit., p. 908. 
justamente não há esquema. Se irritação há (...) é muito mais em função da ausência de esquema. Nada que se assemelhe a um esquema como infra-estrutura e superestrutura do ciclo maltusiano, ou oposição entre sociedade civil e Estado: nenhum desses esquemas que asseguram, explicitamente ou implicitamente, as operações habituais dos historiadores há cinqüenta, cem e cento e cinqüenta anos." 182

A crítica à centralidade do Estado no pensamento e na análise da política é certamente algo que acompanha todo o percurso investigativo de Foucault no que diz respeito ao poder. Como vimos no capítulo anterior, um dos pontos mais célebres de sua obra ocorre em $A$ vontade de saber, quando ele afirma que é necessário, nesse âmbito, cortar a cabeça do rei. ${ }^{183}$ Existe, também, uma passagem quase tão célebre sobre o assunto, em uma entrevista de 1977, dada a Pascoale Pasquino e Alessandro Fontana. Esses dois entrevistadores, após Foucault reafirmar o que tinha dito no livro (sobre o rei e a sua cabeça) insistem em que não só a cabeça do rei não foi cortada, mas no fato de que se quer criar uma para o Estado, "um sujeito, um grande sujeito molar, totalitário". Foucault então aprofunda:

"Colocar a questão em termos de Estado, é ainda coloca-la em termos de soberano e de soberania e em termos de lei. Descrever todos esses fenômenos de poder em função do aparelho de Estado, é coloca-los essencialmente em termos de função repressiva: o exército que é um poder de morte, a polícia e a justiça que são instâncias da penalidade... Eu não quero dizer que o Estado não seja importante; o que eu quero dizer é que as relações de poder e em consequiência a análise que dele deve-se fazer, devem ir além do enquadramento do Estado. $\mathrm{E}$ isso em dois sentidos: primeiro, porque o Estado, compreendido na sua onipresença e nos seus aparelhos, está bem longe de recobrir todo o campo real das relações de poder; em seguida, porque o Estado não pode funcionar a não ser sobre a base de relações de poder preexistentes. O Estado é superestrutural para toda uma série de redes de poder que atravessam os corpos, a sexualidade, a família, as atitudes, os saberes, as técnicas e essas relações mantêm uma relação de condicionante/condicionado em relação a uma espécie de meta-poder estruturado essencialmente em torno de um certo número de grandes funções de interdição. Mas esse metapoder que dispõe de funções de interdição não pode realmente dispor de controle e ele não pode se manter a não ser na medida em que se enraíza em toda uma série de relações de poder múltiplas, indefinidas e que constituem a base necessária dessas grandes formas de poder negativas; é isso o que eu gostaria de trazer à tona." 184

Como visto anteriormente, nos cursos de 1978 e 1979 há uma evolução dessa percepção

crítica a respeito do Estado. Com a introdução do conceito de governamentalidade,

\footnotetext{
${ }^{182}$ FOUCAULT, Michel; "Table ronde du 20 mai 1978”, in DE II, texto n’ 278, p. 852.

${ }^{183}$ Cf. infra, nota $\mathrm{n}^{\mathbf{0}} 105$.

${ }^{184}$ FOUCAULT, Michel; "Entretien avec Michel Foucault", in DE II, texto no 192, p. 151.
} 
Foucault passou a se perguntar se esse "monstro frio" não seria um episódio a mais na longa história dessa técnica de poder. ${ }^{185}$ Mas, ainda, persistia o segundo dos elementos que compõem a equação através da qual "há cento e cinqüenta anos"—no mínimo—é feita a leitura dos fenômenos que comporiam a chamada política: a sociedade, ou sociedade civil.

Uma leitura apressada das idéias de Foucault poderia conduzir no sentido de ver nele, com essa sua forma de achar o Estado moderno algo que não possui essa importância toda que lhe é atribuída, um pensador liberal, desses que advogam a vigência de um Estado mínimo em favor de uma sociedade que, possuindo uma economia "livre", encontra em si mesma os princípios necessários de uma regulação. A análise, contudo, que ele faz do conceito de sociedade civil dissipa qualquer desconfiança nesse sentido—mostrando, na verdade, que o que ele critica é a leitura da política que é feita com o auxílio e a partir dessa noção, o Estado. A sociedade civil— essa realidade transacional ${ }^{186}$ _, diz ele no final de Naissance de la biopolitique, é apenas "uma nova referência, uma nova realidade sobre a qual se exercerá a arte de governar", dado que "um governo onipresente, um governo ao qual nada escapa, um governo que obedece às regras de direito e um governo que, entretanto, respeita a especificidade da economia, esse será um governo que gerirá a sociedade civil, que gerirá a nação, que gerirá a sociedade, que gerirá o social."187 A sociedade, portanto, tampouco é para Foucault um enquadramento válido para a leitura das relações de poder. $^{188}$

\footnotetext{
${ }^{185}$ Cf. a seção "Pastoralidade" do capítulo anterior.

${ }^{186}$ Cf. nota 162 do capítulo anterior.

${ }^{187}$ FOUCAULT, Michel; Naissance de la biopoltique, op. cit. p. 300, grifos meus.

${ }^{188}$ E nem mesmo como quadro de referência epistemológico, como diz aos historiadores no final da mesa-redonda de 1978: "Talvez o meu problema não seja o de construir um novo (esquema) ou de validar um que já tenha esteja pronto. Talvez porque o meu problema não é o de propor um princípio de análise global da sociedade. E é aí que o meu projeto é, de cara, diferente daquele dos historiadores. Esses
} 
Excluídos esses dois referenciais, Estado e sociedade civil, surge a possibilidade de uma nova leitura da política, uma leitura que toma o poder no seu exercício e que tem na distinção entre governantes e governados o seu eixo gravitacional. A política pode passar a ser lida por meio dessa nova "grade" de leitura, desse novo "método de decifração". ${ }^{189} \mathrm{E}$ as conseqüências disso são nada mais nada menos do que a possibilidade de vir a se vislumbrar uma noção de liberdade que extrapola os limites a que, no Ocidente, ela foi confinada desde o surgimento do pensamento político liberal, há cerca de trezentos, trezentos e cinqüenta anos. Uma concepção que teve o seu início, aparentemente paradoxalmente, em Thomas Hobbes, o pensador do Leviatã.

Como mostra Renato Janine Ribeiro, diante das diversas liberdades brandidas ao longo do Renascimento-que teriam dado, como mostrou Skinner, origem ao Estado moderno-, "o que Hobbes percebe é que a liberdade constitui forte arma de persuasão, quase a principal, e com isso detém enorme poder político." Ele então "decide destruir o sentido retórico dessa liberdade, e substituí-lo por uma definição científica", cuja formulação seria a de que "liberdade é 'ausência de impedimentos externos"”. ${ }^{190}$ Essas liberdades renascentistas, diz Ribeiro, são tidas por esse pensador como sendo o resultado do "aprendizado dos idiomas clássicos, grego e latim", e teriam sido responsáveis por um "enorme derramamento de sangue no Ocidente"191, uma "efusão" desse, que a ciência política, que ele presumia estar em vias de criar, viria a poder

(tenham eles razão ou não, eis uma outra questão) fazem da 'sociedade' o horizonte geral da sua análise e a instância em relação à qual eles devem situar tal ou qual objeto particular ('sociedade, economia, civilização'). Meu tema geral não é a sociedade, é o discurso verdadeiro/falso: quer dizer, é a formação correlativa de domínios, de objetos e de discursos verifiáveis e falsifiáveis que lhes dizem respeito; e não é simplesmente essa formação que me interessa, mas os efeitos de realidade que lhe são ligados." (FOUCAULT, Michel; “Table ronde du 20 mai...”, op. cit., pp. 852-853.)

${ }^{189} \mathrm{Cf}$. infra nota $\mathrm{n}^{\circ} 168$ do capítulo anterior.

${ }^{190}$ Ribeiro, Renato Janine; “O poder das palavras: Hobbes sobre a liberdade”, in Novaes, Adauto (org.); O avesso da liberdade; São Paulo, Companhia das Letras, 2002, p. 140.

${ }^{191}$ Idem, p. 141. 
estancar. ${ }^{192}$ Vislumbra-se, portanto, um enorme perigo na liberdade, um perigo que, como aponta Ribeiro, em Hobbes, decorre de um temor, ou um respeito muito grande, à linguagem, às palavras e ao seu poder. Isso criaria-“todo o trabalho do pensamento hobbesiano" consistindo em "evitar esse armamento verbal"—um paradoxo "pelo menos curioso, talvez instrutivo", segundo Ribeiro: "Hobbes quer reprimir a palavra, mas justamente porque ele crê—ao contrário de tantos de nós—no poder que ela possui. Mesmo quando a quer controlar, uma homenagem ele lhe presta-porque sabe que essas pequenas palavras, liberdade e alma ou salvação são poderosíssimas, mais talvez do que o exército de um rei." 193

Que esse paradoxo seja "pelo menos curioso, talvez instrutivo" é um grande eufemismo, ou uma tentativa de sutilizar-com o uso, pedagógico, indutor do pensamento, do "talvez"-, algo que parece ser gritante e que está relacionado a esse paradoxo ser um paradoxo fundamental, constituidor de uma definição de liberdade que é descrita, por alguns, como a "liberdade dos modernos" e que se opõe, desde o ensaio que Benjamin Constant dedicou a essa definição, à "liberdade dos antigos". Reconhecer o poder da palavra, "ao contrário de tantos de nós", insinua uma tomada de posição em favor da livre expressão, do diálogo aberto e sem entraves, da crença em um consenso em detrimento do uso da força. Mas, ao mesmo tempo, reconhece-se que essa tomada de posição está calcada numa repressão, numa proibição—seja esta na forma de uma

\footnotetext{
${ }^{192}$ Idem, p. 142. Ribeiro, hobbesiano, faz, na seqüência dessa exposição do sentido da obra de Hobbes, uma interessante digressão a respeito de como essa laicização da política, que a esfria, tornando-a "científica", acaba convivendo, na realidade, com uma outra política, apaixonada, que "acredita que só vale a pena participar da coisa pública quando valores mais altos, os éticos, estiverem presentes", assim configurando "uma das antinomias da política de hoje". (Idem, p. 144) Essa "antinomia", por sua vez é o ponto de partida de Ribeiro para pensar formas de, diríamos, "esquentar" a política laicizada e científica, com o reconhecimento do caráter desejante das "relações sociais e políticas", em detrimento a um suposto apego à "idéia de direito", de "ciência", de "sabedoria" e de "moderação" vigente. (Idem, p. 146)

${ }^{193}$ Idem, p. 148.
} 
cientifização, de uma regulamentação ou de uma permissão, limitada, à "folia"194_ de determinadas palavras, de determinados pensamentos ou discursos.

Quentin Skinner, em Liberdade antes do liberalismo, é bem mais direto quando chama a doutrina, nascida no século XVII, de que "mesmo a força coerciva da lei deixa a sua (dos membros de uma associação civil) liberdade natural inalterada"-e da qual Hobbes teria sido o formulador mais preciso ao dizer que "geralmente todas as ações que os homens desempenham em comunidades, por temor da lei, são ações que seus autores tinham a liberdade de omitir""195_ de "paradoxal". O que essa doutrina faz, mostra ele, é estabelecer uma total separação entre "o estabelecimento de Estados livres e a manutenção da liberdade individual"196, separação essa que é revelada quando Hobbes, no Leviatã, despreza "a república autogovernante de Lucca" dizendo que seus cidadãos se iludem ao pensar que sejam mais livres do que se vivessem sob o sultão em Constantinopla, pois "o que importa para a liberdade individual não é a fonte da lei, mas sua extensão, e portanto (...) 'se uma Comunidade é Monárquica ou Popular, a Liberdade é ainda a mesma.",197 Para esse historiador inglês do pensamento político, essa recusa de Hobbes em ver essas duas liberdades como uma só coisa, "foi imediatamente assumida por Filmer, sendo repetida desde então"-por pensadores como Benjamin Constant e Isaiah Berlin, diz ele em nota de rodapé. Esses autores, de épocas tão diferentes, são unânimes em tentar provar que um discurso a respeito da liberdade oposto a esse—como é aquele, "neo-romano", cuja história ele "desencava" nesse pequeno e importante livro—é um discurso que se preocupa com "a liberdade das cidades, não com a liberdade dos cidadãos individuais"; mas, ressalva Skinner, não o

\footnotetext{
194 São as três opções que Ribeiro dá de "desarmamento" das palavras. (Idem, ibid.)

195 SKINNER, Quentin; Liberdade antes do liberalismo; São Paulo, Editora Unesp, 1999, p. 19.

${ }^{196}$ Idem, p. 55.

${ }^{197}$ Idem, p. 73.
} 
conseguem, pelo menos no que diz respeito a esse discurso "neo-romano", na medida em que essa alegação "não consegue lidar com a estrutura da teoria neo-romana da liberdade." 198

E o que diz essa teoria? O que é que a sua estrutura possui que não é percebido ou é negligenciado por toda essa outra corrente de pensamento sobre a liberdade? Bom, basicamente, no que diz respeito à primeira dessas perguntas, que "só é possível ser livre num Estado livre". ${ }^{199}$ Diz Skinner, a esse respeito-quando começa a descrever os elementos de que essa teoria é composta-, que a primeira das suposições comuns desses teóricos políticos é a de que "qualquer compreensão do que significa para um cidadão individual possuir ou perder sua liberdade deve estar incluída no interior de uma explicação do que significa para uma associação civil ser livre." ${ }^{200}$ A segunda estaria contida na relação que se estabelece entre falta de liberdade e escravidão, ou dependência e pode ser expressa no dizer que esses teóricos resgatam dos moralistas e historiadores romanos, via Maquiavel ${ }^{201}$, de que a liberdade seja "a capacidade de 'manter-se reto por meio de sua própria força sem depender da vontade de alguém mais'."202 Sem dúvida, estamos aí distantes desse modelo que desvincula o "estabelecimento de um Estado livre" da "liberdade dos indivíduos" e que, ao tentar resguardar o espaço de exercício dessa segunda, se baseia num ato de inicial de repressão, de supressão ou esfriamento, de determinadas palavras, como vimos, demasiado "perigosas".

Isso daria margem a concordar com os teóricos dessa outra vertente quando dizem que quando não se fala nos termos que eles propõem para o entendimento da

\footnotetext{
${ }^{198}$ Idem, p. 56.

${ }^{199}$ Idem, ibid.

${ }^{200}$ Idem, p. 31.

${ }^{201}$ Cf. idem, p. 47.

${ }^{202}$ Idem, ibid.
} 
liberdade, fala-se de uma outra coisa, que não é aquela que lhes interessa; o que lhes interessa é a liberdade individual e não a coletiva e qualquer outra fala a respeito da liberdade que não diga respeito exclusivamente à primeira é tudo menos uma fala que procura a liberdade, ou que tenha alguma chance de realiza-la. Contudo-e aí respondendo à segunda questão acima formulada—, Skinner nos mostra que os teóricos neo-romanos da liberdade não descartavam a liberdade individual ao dizer que só se é livre vivendo num Estado livre. Eles buscavam ambas as liberdades, do indivíduo e do coletivo, porque acreditavam que esse era o único meio de garantir a primeira:

\begin{abstract}
"os autores neo-romanos aceitam plenamente que a extensão de sua liberdade como cidadão deveria ser medida pela extensão na qual você é ou não constrangido de agir à vontade na busca de seus fins escolhidos. Ou seja, eles não discordam do princípio liberal de que, como Jeremy Bentham iria mais tarde formular, o conceito de liberdade 'é um conceito meramente negativo' no sentido em que sua presença é sempre assinalada pela ausência de algo e, especificamente, pela ausência de alguma medida de restrição ou constrangimento. Tampouco têm eles o desejo de negar que o exercício da força ou sua ameaça coerciva devam ser elencados entre as formas de constrangimento que interferem com a liberdade individual. A despeito do que vários comentadores recentes sugeriram, eles estão longe de simplesmente querer adiantar uma explicação alternativa da nãoliberdade, de acordo com a qual esta é considerada o produto não de uma coerção, mas apenas de dependência. (...) O que, então, separa a compreensão da liberdade neoromana da liberal? O que os autores neo-romanos repudiam avant la lettre é a suposição fundamental do liberalismo clássico de que a força ou a sua ameaça coerciva constituam as únicas formas de constrangimento que interferem com a liberdade individual. Os autores neo-romanos insistem, por contraste, em que viver numa condição de dependência é em si uma fonte e uma forma de constrangimento. Assim que você reconhece estar vivendo nessa condição, isto pode servir para constrange-lo de exercer vários de seus direitos civis. É por isso que eles insistem, pace Paley (William Paley, teórico liberal de finais do setecentos, crítico em relação a essa teoria, sob o argumento de que ela era utópica e, principalmente, de que ela confundiria "liberdade" — entendida por ele como inversamente proporcional ao "número e severidade" de restrições impostas aos indivíduos na consecução de "seus fins escolhidos"—com "segurança" para tal—com base numa definição que tomaria a "extensão" de liberdade para o desempenho das ações escolhidas, como ponto de partida-), que viver em tal condição é sofrer uma diminuição não meramente da segurança para sua liberdade, mas da sua própria liberdade."
\end{abstract}

A dependência ser uma fonte e uma forma de constrangimento a ser acrescida a um possível constrangimento (ou ameaça de) físico na limitação de uma liberdade quer dizer, no meu entender, que ela se situa justamente nesse campo que Hobbes tanto

${ }^{203}$ Idem, pp. 71-72. 
temia, o campo das palavras, da linguagem ou, posto de outra forma, do pensamento. Há coisas que não convêm serem pensadas, diz a doutrina liberal iniciada em Hobbes, ao passo que os autores neo-romanos parecem dizer: que liberdade eu vou ter se não puder (sequer) pensar livremente? A noção de sociedade civil, que surge em concomitância à de uma instância soberana que se apresenta como indispensável na medida em que a regula (Hobbes)—e que carrega consigo a figura do cidadão, o sujeito de direitos-, recebe, da parte do pensamento liberal, toda a carga de liberdade concebível: é nela que se dará a liberdade, toda a liberdade possível—bem como toda a política, também, possível—, ao passo que para os autores neo-romanos essa limitação já diz que, nesse caso, nem tudo é pensável, que há um constrangimento que é dessa ordem (do pensamento) e que, portanto, não há, aí, liberdade. Eis onde se pode começar a encontrar um ponto de forte convergência com a perspectiva que a noção de governamentalidade traz consigo a respeito da política. Os teóricos neo-romanos, mostra-nos Skinner, ignoravam "a noção moderna de sociedade civil como um espaço moral entre governantes e governados", usando o termo "apenas para distinguir o estado de natureza do estado em que vivemos como membros de uma comunidade"por exemplo, às vezes contrastando-o com a família-e preocupando-se "quase exclusivamente com a relação entre a liberdade dos súditos e os poderes de Estado."204 A liberdade, para eles, assim como para Foucault, como vimos, não tinha o seu espaço pré-definido dentro dos limites de qualquer coisa chamada sociedade, civil ou não, ou mercado; dava-se na relação diária, diuturna, direta entre governantes e governados e, daí, era prenhe de possibilidades_-inclusive da possibilidade de não serem necessários, em certos casos, governantes (ou então, quando necessários, aceitos desde que não obrassem no sentido de impor uma dependência). Eles provavelmente concordariam 
com as palavras de Foucault, quando esse diz, como visto acima, que a liberdade é "uma relação atual entre governantes e governados, uma relação na qual a medida do ‘demasiado pouco' de liberdade que existe é dada pelo 'mais ainda' de liberdade que é reivindicada" 205 ; e estariam de acordo, também, com a sua análise de que "o liberalismo não é tanto assim o imperativo da liberdade quanto a gestão e a organização das condições nas quais se pode ser livre" e que, portanto, "produzindo-a, corre o risco de limita-la ou destruí-la" ${ }^{206}$, e de que, a partir daí, a fórmula liberal e neo-liberal—essa fórmula paradoxal em que a liberdade, como vimos, é louvada, homenageada, mas, ao mesmo tempo temida, "evitada", em função das paixões que pode despertar-é o novo rearranjo de uma arte de governar, de uma "razão governamental" que data do início da era cristã. Como diz Foucault: "durante muito tempo a idéia de regrar, de medir e, por conseguinte, de limitar o exercício indefinido do poder era buscada numa sabedoria daquele que governava. (...) A partir dos séculos XVI-XVII (...) não se busca mais regrar o governo pela verdade, mas se busca regrá-lo pela racionalidade"; e isso, segundo duas formas: pela "racionalidade entendida como individualidade soberana (...) a racionalidade daquele que pode dizer 'eu, o Estado"” e a "racionalidade daqueles que

${ }^{205}$ Cf. nota $\mathrm{n}^{\mathrm{o}} 166$ do capitulo anterior. O fato de ela ser "atual", dentre outras coisas, parece-me indicar o fato de que ela é pensável, sempre; sempre sujeita a ser revista, questionada, criticada e, em suma, reivindicada nas relações entre governantes e governados.

${ }^{206} \mathrm{Cf}$. nota $\mathrm{n}^{\circ} 167$ do capítulo anterior. Essa característica do liberalismo fica mais clara um pouco mais à frente em Naissance de la biopolitique, quando Foucault analisa o ordoliberalismo alemão cuja lógica seria a de que "não existirá o jogo do mercado que é preciso deixar livre e em seguida o campo onde o Estado começará a intervir, pois precisamente o mercado, ou melhor a concorrência pura, que é a essência mesma do mercado, não pode aparecer a não ser que se ela é produzida, e que se ela é produzida por uma governamentalidade ativa. Teremos então uma espécie de sobreposição total dos mecanismos de mercado indexados sobre a concorrência e da política governamental. O governo deve acompanhar de cabo a rabo uma economia de mercado. A economia de mercado não tira coisa alguma ao governo. Ela indica ao contrário, ela constitui o índice geral sobre o qual é preciso colocar a regra que vai definir todas as ações governamentais. É preciso governar para o mercado, muito mais do que governar por causa do mercado." (FOUCAULT, Michel; Naissance de la biopolitique, op. cit., pp. 124-125.) Ou então quando ele diz que o problema da (a ser resolvido pela) política liberal é "agenciar", "arrumar" o "espaço concreto e real no qual poderia ter lugar a estrutura formal da concorrência." (Idem, p. 137) 
são governados, aqueles que são governados enquanto sujeitos econômicos e, de uma maneira mais geral, enquanto sujeitos de interesse." 207

A convergência, como veremos mais à frente, se consolidará, no aprofundamento que Foucault vai dar à questão da governamentalidade, por meio da noção de (atitude) crítica, que vai fazer com que ele se reaproxime de Kant e dos seus textos que falam sobre a liberdade.

\subsubsection{Governantes e governados, conflito e consenso}

Um exemplo do que seria o exercício dessa nova noção de liberdade como

relação atual entre governantes e governados pode ser encontrado em duas conferências

207 Idem, pp. 315-316. Essas três formas de racionalidades governamentais, a sua concomitância e sobreposição, fazem, para Foucault, o "objeto do debate político desde o século XIX". Assim, ele termina esse curso de 1979: "o que é a política finalmente se não ao mesmo tempo o jogo dessas diferentes artes de governar com os seus diferentes índices e o debate que essas diferentes artes de governar suscitam. Eis onde, parece-me, que nasce a política.'(Idem, pp. 317) Quanto a essa racionalidade governamental que se pauta pelos governados enquanto sujeitos econômicos ou sujeitos de interesse (ou seja, a governamentalidade de tipo liberal) remeto o leitor à nota $\mathrm{n}^{\mathrm{o}} 163$ do capítulo anterior, que mostra a diferença entre esse sujeito e o sujeito da razão governamental que gira em torno da noção de Razão de Estado. Outro ponto que merece atenção é que Foucault, ao apontar essa concomitância de governamentalidades, liga o marxismo à primeira —e mais antiga—, pois, diz ele: "afinal de contas, o que é finalmente algo como o marxismo se não a procura de um tipo de governamentalidade que será indexada, com certeza, a uma racionalidade, mas uma racionalidade que não se apresentará dessa forma como a racionalidade dos interesses individuais mas como a racionalidade de uma história que se manifesta, pouco a pouco, como verdade?" (Idem, p. 316) É preciso, por último, fazer aqui uma digressão a respeito dessa diferenciação onde uma das modalidades aparece como sendo regrada pela "verdade". Isso pode conduzir a que se entenda que a noção de verdade, de discurso verdadeiro, não se aplique às outras duas modalidades, o que não corresponde ao que Foucault, como vimos acima, pensa a respeito dessas duas outras artes de governo: tanto os elementos-a "estatística" (cf. nota 139 do capítulo anterior)—que compõem a racionalidade governamental da Razão de Estado, quanto o mercado—no caso do razão governamental liberal-são "índices" dessas racionalidades porque constituem-se como verdades, como fonte de dizeres verdadeiros. 
que Foucault deu, em 1976 e 1978, onde ele aborda a prisão, essa instituição que faz parte de todas as democracias modernas e que ele já havia demonstrado, em Vigiar $e$ punir, ser de grande utilidade para a legitimação dos mecanismos de controle dessas sociedades_-por meio da fabricação da delinqüência que, por sua vez, passaria a "ter" que ser gerida, junto com toda uma coorte de ilegalismos. Ao final da primeira dessas, diz Foucault:

“a questão da prisão não pode portanto se resolver, e não pode nem mesmo ser colocada, nos termos da mera teoria penal. Ela não pode muito mais ser colocada nos simples termos da psicologia ou da sociologia do crime. Não se pode coloca-la, a questão da prisão, do seu papel e da sua possível desaparição, a não ser nos termos de uma economia e de uma política, se quiserem, de uma economia política dos ilegalismos. (...) As questões que é preciso colocar ao poder não são: vocês irão ou não fazer parar de funcionar essas horríveis prisões que nos fazem tanto mal à alma?-quando não somos prisioneiros e então nos fazem mal ao corpo. É preciso dizer ao poder: termine com essas tagarelices sobre a lei, acabe com esses seus propalados esforços para fazer respeitar a lei, diga-nos muito mais um pouco o que você faz com os ilegalismos. O verdadeiro problema é: quais são as diferenças que vocês, pessoas no poder, se estabelecem entre os diferentes ilegalismos? Como vocês tratam os seus e como e como vocês tratam os dos outros? Para que lhes servem os diferentes ilegalismos que vocês gerem? Que benefícios vocês extraem destes e daqueles?"208

Na segunda:

"tomem o caso das prisões (no que diz respeito a como as lutas devem ser conduzidas nos dias atuais). Há anos e anos, eu diria, há séculos, em todo caso depois que a prisão existe como tipo de punição no interior dos sistemas penais ocidentais, desde o século XIX, toda uma série de movimentos, de críticas, de oposições por vezes violentas tiveram cabo a fim de tentar modificar o funcionamento da prisão, a condição do prisioneiro, o estatuto que eles têm seja na prisão, seja depois. Nós sabemos que não se trata mais agora, e pela primeira vez, desse jogo ou dessa resistência, dessa posição assumida no interior mesmo do jogo; trata-se de uma recusa propriamente ao jogo. O que nós dizemos é: não mais prisões nenhumas. E quando, a essa espécie de crítica massiva, as pessoas razoáveis, os legisladores, os tecnocratas, os governantes perguntam: 'Mas então o que vocês querem?', a resposta é: 'Não cabe a nós dizermos com que molho queremos ser devorados: nós não queremos mais jogar esse jogo da penalidade; nós não queremos mais jogar esse jogo das sanções penais; nós não queremos mais jogar esse jogo da justiça' ., 209

Em ambos esses casos, vê-se, há a sinalização no sentido de uma relação direta, sem mediação, entre governantes e governados. É aí, nessa relação, que está a possibilidade

${ }^{208}$ FOUCAULT, Michel; "Prisons: la chute des murs?", in Vacarme, n $^{\circ}$ 29, automme 2004, p. 145.

${ }^{209}$ FOUCAULT, Michel; "La philosophie analytique de la politique", in DE II, texto $\mathrm{n}^{\circ} 232$, pp. 543-544. 
de mais ou menos liberdade e não no estabelecimento de toda uma rede de instituições pretensamente encarregadas de assegura-la.

E a política? Bem, essa deixa de ser a instância em que diferentes noções de liberdade se digladiam e definem o conjunto de instituições que devem existir-e como elas devem operar - a fim de assegurar essa ou aquela definição, esse ou aquele consenso, para situar-se no espaço de um diálogo direto cujo resultado não é sabido de antemão-e que pode ser, inclusive, como diz o próprio Foucault, a necessidade de se pôr fim ao "jogo".

E o direito? Bem, esse deixa de ser um conjunto normativo decorrente de uma cessão inicial, que constitui o chamado "cidadão", para tornar-se uma espécie de laço espontâneo que une pessoas que sofrem frente aos abusos de poder e que dá ensejo a uma cidadania internacional que não deve depender dos governos para agir ou tomar iniciativa. É a isso o que Foucault passou a chamar de "direito dos governados": um direito "mais preciso, mais historicamente determinado que os direitos do homem: ele é maior que aquele dos administrados e dos cidadãos; nós ainda não lhe formulamos uma teoria", diz ele em 1977, em artigo que defende a não extradição do advogado do grupo terrorista Baader-Meinhof, preso na França, para a Alemanha ${ }^{210}$. Em, 1981, numa conferência de imprensa que anunciava a criação, em Genebra, do Comitê Internacional Contra a Pirataria, ele escreve e lê, logo em seguida, um pequeno texto em que anuncia os três princípios que poderiam passar a reger um direito nesse sentido:

“1) Existe uma cidadania internacional que tem os seus direitos, que tem os seus deveres e que se engaja em se levantar contra todos os abusos de poder, quaisquer que sejam os autores, quaisquer que sejam as vítimas. Afinal de contas, nós somos todos governados e, como tal, solidários.

2) Porque eles pretendem ocupar-se da felicidade das sociedades, os governos se arrogam o direito de passar para o balanço de ganhos e perdas a infelicidade dos homens que as suas decisões provocam ou que as suas negligências permitem. É um dever dessa

${ }^{210}$ FOUCAULT, Michel; "Va-t-on extrader Klaus Croissant?", in DE II, texto no 210, p. 362. 
cidadania internacional sempre fazer valer aos olhos e aos ouvidos dos governantes as infelicidades dos homens da qual não é verdade que eles não sejam responsáveis. A infelicidade dos homens não deve jamais ser a sobra muda da política. Ela funda um direito absoluto de se levantar e de se dirigir àqueles que detêm o poder.

3) É preciso recusar a partilha de tarefas que, muito freqüentemente, nos é proposta: que cabe aos indivíduos se indignar e falar; e aos governos refletir e agir. É verdade: os bons governos adoram a santa indignação dos governados, contanto que ela permaneça lírica. Eu acho que é preciso se dar conta que muito freqüentemente são os governantes que falam, não podem e não querem nada além de falar. A experiência mostra que pode-se e deve-se recusar o papel teatral da pura e simples indignação que nos é proposto. Anistia Internacional, Terra dos Homens, Médicos do Mundo são iniciativas que criaram esse novo direito: o dos indivíduos privados intervindo efetivamente na ordem das políticas e das estratégias internacionais. A vontade dos indivíduos deve se inscrever numa realidade da qual os governos têm querido se reservar o monopólio, esse monopólio que é preciso deter pouco a pouco e a cada dia." 211

São sempre os indivíduos, em carne e osso, que sofrem diante do poder-mas que também podem se alegrar, ou melhor, gozar-, os elementos a compor o jogo ou os jogos que Foucault vislumbra como sendo aqueles que lhe interessam ${ }^{212}$ - porque neles reside a possibilidade sempre nova da liberdade. Os "adversários" podem ser os administradores das prisões, os teóricos do direito ou os políticos que legitimam a existência de uma instituição tal como a prisão, como também podem ser os políticos e tecnocratas responsáveis por medidas que fazem com que, globalmente, pessoas queiram abandonar sua terra natal, arriscando-se em travessias das quais não sabem se vão sair vivos ou não. Ou, então, podem ser os próprios chefes de Estado, como foi o

${ }^{211}$ FOUCAULT, Michel; "Face aux gouvernements, les droits de l'homme", in DE II, texto no 355, pp. 1526-1527.

${ }^{212}$ Isso se estende também à literatura, como dá exemplo o texto, de 1977, que introduz uma coletânea que ele viria a organizar-mas que acabou virando um outro livro, posterior, em parceria com a historiadora Arlette Farge-de registros administrativos do Hospital Geral e da Bastilha, com os quais tinha se deparado ao longo dos anos. Esses registros dão notícias de acontecimentos relativos a homens e mulheres-vidas "obscuras", "infames", "existências que são destinadas a passar sem deixar traço algum"-que, por algum motivo, vieram a entrar em contato com essas instituições e, para Foucault, ainda que "nenhum valerá jamais a menor passagem de Tchekhov, de Maupassant ou de James" (FOUCAULT, Michel; "La vie des hommes infâmes", in DE II, texto no 198, p. 253), teriam "balançado" nele "mais fibras do que aquilo que ordinariamente chamamos de literatura" (Idem, p. 238), dada a sua intensidade, o seu ardor; o seu critério de seleção teria, então, se pautado pelo fato de que "houvesse nas suas infelicidades, nas suas paixões, nos seus amores e nos seus rancores qualquer coisa de cinza e de ordinária aos olhos daquilo que se tem habitualmente como sendo digno de ser contado; que entretanto elas tenham sido atravessadas por um certo ardor, que tenham sido animadas por uma violência, uma energia, um excesso na infelicidade, a vilania, a baixaria, a teima ou a infelicidade que lhes davam aos olhos daqueles em volta, e à proporção mesmo da sua mediocridade, uma espécie de grandeza assustadora ou lamentável. Eu parti à busca dessas espécies de partículas dotadas de uma energia tanto maior quanto elas são tanto menores e difíceis de discernir" (Idem, p. 240) 
caso do presidente francês François Mitterrand: quando este assume, em 1981, o governo francês, perguntam a Foucault o quê se pode esperar de um governo socialista, ao que ele responde:

"essa eleição foi vista por muitos como uma espécie de acontecimento-vitória, isto é, uma modificação da relação entre governantes e governados. Não que os governados tenham assumido o lugar dos governantes. Afinal de contas, tratou-se de um deslocamento na classe política. Entra-se em um governo de partido com todos os perigos que isso comporta, e isso não pode ser esquecido. Mas o que está em jogo a partir dessa modificação é saber se é possível estabelecer entre governantes e governados uma relação que não será uma relação de obediência, mas uma relação na qual o trabalho terá um papel importante." 213

O diálogo que interessa a Foucault, a sua política, portanto, pode e deve se dar em todos esses níveis: local, nacional, global. E o que permite que isso se dê é justamente essa característica de não mediação. Diariamente, cada um de nós se depara com instâncias diversas de poder, que se situam nesses três níveis. O poder, seu exercício, essa técnica pastoral de condução de condutas, por acaso, não estava, nessa mesma época, nos mostrando Foucault que funciona operando uma totalização, ao mesmo tempo que uma singularização, uma individualização ${ }^{214}$ ? Pois bem, então, a partir do momento em que consigamos enxergar isso, poderemos deixar de acreditar que a política não seja algo que passe pelo corpo de cada um de nós, por nossa singularidade e que, ao mesmo tempo, não possamos nos importar com causas de pessoas que sofrem até mesmo em outros locais da terra que não os nossos países, as nossas nações, as nossas repúblicas, essas mônadas que a teoria política há trezentos e cinqüenta anos vem apontando como os únicos e exclusivos-porque nela é que ocorre essa transformação, dizem-nos, necessária, de indivíduo em cidadão-lugares de exercício da política. Enquanto governados, mostra-nos Foucault, temos o direito de levantar questões àqueles que nos governam ou que querem nos governar, sejam eles nossos pais, nossos

${ }^{213}$ FOUCAULT, Michel; "Est-il donc important de penser?", in DE II, texto nº 296, p. 998.

${ }^{214}$ Cf. nota 149 do capítulo anterior. 
cônjuges, patrões, orientadores, síndicos de condomínio, nossos planejadores urbanos, administradores de todo tipo-inclusive da justiça—, membros de assembléias legislativas, gestores públicos, governadores, presidentes, imperadores ou candidatos a tal. E é desse direito-que por sua vez decorre da nossa capacidade crítica, essa que, como veremos adiante, Foucault define como "a arte de não ser assim governado"215 que emerge uma possibilidade da qual já falamos acima ${ }^{216}$ : a possibilidade da sublevação.

Na visão de Foucault, que em 1978 tinha tudo isso-liberdade, governantes e governados, governametalidade—na cabeça, foi isso o que os iranianos fizeram na sua "revolução"217: se deram conta de que nesse jogo entre governados e governantes, "entre liberdades", onde o que está sendo jogado é a liberdade, não restava outra alternativa. Em maio de 1979, quando começava a ficar claro que o governo islâmico do Ayatollah Khomeini não tinha escrúpulos em assassinar-ou, no mínimo, cortar as mãos-(d)aqueles que fugissem a seus ditames, Foucault publica um artigo no Le Monde, em que, de início, define essa ação, vinculando-a a uma irredutibilidade:

"porque nenhum poder é capaz de torna-la absolutamente impossível: Varsóvia terá sempre o seu gueto revoltado e os seus esgotos apinhados de insurgentes. E porque o homem que se subleva é finalmente sem explicação: é necessário um dilaceramento que

${ }^{215}$ FOUCAULT, Michel; "Qu'est-ce que la critique? (Critique et Aufklärung)", Bulletin de la société française de philosophie, ano 84, $\mathrm{n}^{\circ}$ 2, Avril-Juin, 1990, p. 38.

${ }^{216} \mathrm{Cf}$. nota 80 do capítulo anterior.

${ }^{217}$ Acima, ao falarmos de sublevação e da sua diferença em relação à revolução, fizemos isso por meio de uma citação de um texto de 1979, em que Foucault lamenta a morte do amigo Maurice Clavel. Agora, citamos um trecho desse mesmo artigo, em que Foucault lança mão de uma compreensão sua a respeito da liberdade - como que para mostrar que essas duas coisas, liberdade e sublevação, caminham juntas, a segunda sendo um horizonte sempre presente da primeira-: "E tão simplesmente, tão corajosamente ele a tinha colocado (a liberdade) naquilo que acontece, por excelência, para negá-la. Ele a via próxima ao relâmpago que atordoa, ao clarão Divino, àquilo que torna ao avesso, no homem, o próprio homem. A liberdade não estava para ele nos recantos da reflexão, na sabedoria do escravo mantido em cativeiro e nem no pensamento do filósofo que crê reconhece-la sob o rosto necessário da totalidade. Ele a capturava no inevitável acontecimento que rompe tudo e o Todo. É afrontando a extrema e singular vontade de Deus que se é livre. Teólogo abrupto, fazia da força invencível da Graça o momento de liberdade." (FOUCAULT, Michel; "Vivre autrement le temps", in DE II, texto nº 268, p. 789.) 
interrompe o fio da história e os seus longos encadeamentos de razões, para que um homem possa, 'realmente', preferir o risco da morte à certidão de ter que obedecer.",218

E em que, em seguida, especula a respeito da revolução-_ela constituiu um gigantesco esforço para aclimatar a sublevação no interior de uma história racional e controlável”219 — para, então, se fazer a pergunta que dá título a esse artigo: é inútil sublevar-se? Diz Foucault, a esse respeito:

"ninguém tem o direito de dizer: 'revolte-se por mim, disso depende a liberação final de todo homem'. Mas eu não estou de acordo com aquele que diria: 'inútil sublevar-se, sempre será a mesma coisa'. Não se faz a lei a quem arrisca a sua vida diante de um poder. Tem-se ou não razão de se revoltar? Deixemos a questão em aberto. Subleva-se, eis um fato; e eis por onde a subjetividade (não aquela dos grandes homens, mas aquela de um João-Ninguém) se introduz na história e lhe dá seu alento. Um delinqüente joga a sua vida contra os castigos abusivos; um louco não agüenta mais ser enclausurado e destituído; um povo recusa o regime que o oprime. Isso não torna inocente o primeiro, não cura o segundo e não assegura ao terceiro os porvires prometidos. Ninguém, por outro lado, é proibido de lhes ser solidário. Ninguém é proibido de achar que essas vozes confusas cantam melhor que as outras e dizem o fino substrato do verdadeiro. Basta que elas existam e que elas tenham contra si tudo isso que se obstina em faze-las se calar, para que exista um sentido em escuta-las e em buscar o que elas querem dizer. Questão de moral? Pode ser. Questão de realidade, seguramente. Todos os desencantos da história nada conseguirão contra elas: é porque existem tais vozes que o tempo dos homens não tem a forma de uma evolução, mas a da 'história', justamente.",220

Esse conceito era um que, pode-se ler na aula de 5 de março de 1978 do curso Sécurité, territoire, population, Foucault teve dificuldade em conceber: nessa aula, que sucede a análise que ele faz do pastorado enquanto "condução de condutas"- e que foi abordada acima $^{221}$ —ele trata daquilo a que ele dá o nome de "crise do pastorado" e começa por dizer que o pastorado, desde o seu berço, foi acompanhado de uma "relação de confronto, de hostilidade, de guerra com alguma coisa que é difícil chamar de revoltas de conduta, na medida em que a conduta, essa forma aí de conduta, em todo caso, não existia ainda de forma clara"222 — dando o exemplo das seitas gnósticas que tiveram lugar no Oriente-Médio ao longo dos séculos II, III e IV—para, em seguida, entregar-se

\footnotetext{
${ }^{218}$ FOUCAULT, Michel; “Inutile de se soulever?”, in DE II, texto n' 269, p. 791.

${ }^{219}$ Idem, ibid.

${ }^{220}$ Idem, p. 793.

${ }^{221}$ Cf. infra, nota 136.

${ }^{222}$ FOUCAULT, Michel; Sécurité, territoire, population; op.cit., p. 198.
} 
a uma especulação a respeito de qual seria o melhor nome para tais "revoltas": insubmissão, dissidência? O termo ao qual acaba chegando e que ele crê, nessa ocasião, ser o mais próximo daquilo que ele quer dizer ${ }^{223}$ —ainda que a palavra seja "mal construída"-, é contra-conduta, ou, "luta contra os procedimentos postos em marcha para conduzir os outros,"224. Seis meses depois, como vimos acima ${ }^{225}$, ele já está usando o termo "sublevação" para referir-se aos acontecimentos no Irã; e pouco mais de um ano depois, a clareza a respeito do que tinha acontecido naquele país autorizava-o a se dirigir em carta aberta ao seu Primeiro-Ministro, Mehdi Bazargan—um "prestigioso mediador entre a corrente laica de defensores dos direitos humanos e os religiosos", que logo viria a demitir-se do cargo, contam-nos os editores dos Dits et écrits-para, diante das execuções sumárias que começavam a ocorrer, lembrar-lhe de uma conversa que ambos haviam tido em meio ao processo revolucionário, em setembro do ano anterior, quando ambos concordaram que um governo, seja ele qual for-islâmico, democrático, liberal, popular—, possui obrigações "muito pesadas" em relação àqueles que por ele são governados, o direito a um julgamento justo sendo uma das principais, a forma com que se dão os "processos políticos" sendo uma "pedra de toque" para o poder público instituído: "eu não tenho, entenda-se bem, Sr. Primeiro-Ministro", termina Foucault dizendo,

"nenhuma autoridade para me dirigir assim à sua pessoa. A não ser a permissão que o senhor me deu, fazendo-me compreender, por ocasião do nosso primeiro encontro, que

\footnotetext{
${ }^{223} \mathrm{E}$ isso que ele quer dizer está condensado, eu diria, no seguinte trecho: "se [portanto] o pastorado é um poder que tem por objetivo a conduta dos homens, eu creio que, correlativamente a isso, apareceram movimentos tão específicos quanto esse poder pastoral, movimentos específicos que são resistências, insubmissões, algo que se poderia chamar revoltas específicas de conduta, aí ainda deixando à palavra 'conduta' toda a sua ambigüidade. São movimentos que têm por objetivo uma outra conduta, isto é: querer ser conduzido de outra forma, por outros condutores e por outros pastores, rumo a outros objetivos e outras formas de salvação, por meio de outros procedimentos e de outros métodos. São movimentos que procuram também, eventualmente, em todo caso, escapar à condução dos outros, que procuram definir para cada um a maneira de se conduzir". (Idem, ibid.)

${ }^{224}$ Idem, p. 205.

${ }^{225}$ Cf. infra, nota $n^{\circ} 27$.
} 
para o senhor, governar não é um direito anelado, mas um dever extremamente difícil. Cabe ao senhor fazer com que esse povo não venha jamais a se arrepender da força sem concessão com a qual ele acaba de se liberar a si mesmo."226

Mas, a sublevação—a de um prisioneiro, de um louco ou de um povo inteiro-é apenas uma das possibilidades nos jogos entre governantes e governados, um recurso extremo. As relações que ocorrem entre esses dois pólos, desde que entendidas enquanto jogo estratégico, enquanto relações que possuem um caráter agonístico-em que, como vimos acima ${ }^{227}$, se dá uma "provocação permanente" entre a "recalcitrância do querer" (ou a "intransitividade da liberdade") e uma vontade de poder, mais do que uma "oposição termo a termo que as bloqueia uma em face à outra"-estarão sempre sujeitas à possibilidade de um diálogo, abertas à perspectiva de uma interlocução, de um permanente questionamento ou, para usar um termo que Foucault passou a empregar sistematicamente a partir de 1983, "problematização"—onde, inclusive, os intelectuais de tipo "específico" (que ele diz, em 1976, serem aqueles que "encontram" "obstáculos" e se "expõem" a "perigos" na medida em que questionam verdades estabelecidas partindo do "local" das especificidades com que lidam para, eventualmente, atingirem "universais"), passam a ter um importante papel enquanto "conversores", "pontos de cruzamento privilegiados" (e não mais "principais" como os intelectuais de tipo "universal”), para uma "politização global"228. E eis aí onde começa toda uma série de tentativas, por parte de pensadores diversos, de integrá-lo ao circuito de pensamento que gira em torno da idéia de consenso, de possibilidade de entendimento baseado numa suposta capacidade comunicativa, ou de um "agir comunicativo" e que é tido como próprio à política: nomeadamente, de relacionar o seu pensamento àquele de Hannah Arendt e de Jürgen Habermas.

\footnotetext{
${ }^{226}$ FOUCAULT, Michel; "Lettre ouverte à Mehdi Bazargan”, in DE II, texto no 265, p. 782.

${ }^{227}$ Cf. infra, nota ${ }^{\circ} 169$.

${ }^{228}$ Cf. FOUCAULT, Michel; "La fonction politique de l'intellectuel”, in DE II, texto no 184, pp. 109-114.
} 
Esses dois pensadores enfatizam a política, opondo-a ao uso da força: no caso da primeira, ao totalitarismo, no caso do segundo, a um agir que não seria comunicativo, crédulo da possibilidade de entendimento, mas sim "instrumental". Em ambos os casos, as fichas são depositadas no diálogo, na tentativa de encontrar entendimentos, consensos. Seria isso o que permitiria afrontar o poder-que é visto como o uso da força—, diluindo-o, anulando-o, não deixando brechas para o seu aparecimento. Os problemas do mundo moderno, as guerras, as injustiças, parecem dizer-nos esses dois pensadores, estariam na falta de política, ou seja, na falta do exercício do diálogo: haveria pouca política no mundo, isto querendo dizer que há pouco diálogo, pouca comunicação, que a capacidade racional do homem não está sendo posta em prática. Um pouco como dizendo que a sociedade civil, enquanto instância mediadora, "espaço moral" entre governantes e governados, não estaria funcionando a contento, que ela precisa de uma reforma, de uma injeção de uma substância qualquer que lhe permitisse passar a agir de acordo com a sua finalidade precípua de instrumento de uma liberdade—já previamente definida, uma condição humana, quase um destino, para não dizer uma "condenação"-, que está sendo atravancada ${ }^{229}$. Mas, essas tentativas de

${ }^{229}$ Esses autores estariam provavelmente de acordo com a afirmação de Norberto Bobbio de que a liberdade, ao contrário da igualdade, é "um valor que indica um estado" e não uma "relação" (agradeço a Maria Luiza Tonnelli o ter me chamado a atenção para essa diferenciação feita por Bobbio)—afinal, não é Arendt que, em "O que é liberdade?", define a "ação, na medida em que é livre" como aquela que brota de um "princípio" que não se exaure na ação a que dá ocasião" (a "honra ou glória", o "amor à igualdade", a "distinção" ou a "excelência" ou ainda, "o medo, a desconfiança ou o ódio" sendo os exemplos citados desses "princípios"), tendo, portanto, uma "validade universal, não se ligando a nenhuma pessoa ou grupo em especial" (ARENDT, Hannah, “O que é liberdade?", in Entre passado e futuro;São Paulo, Perspectiva, 2005, p. 199, grifo meu) e a "faculdade da liberdade", em contextos de "civilizações petrificadas e decadentes", como "a pura capacidade de começar, que anima e inspira todas as atividades humanas e que constitui a fonte oculta de todas as coisas grandes e belas" (Idem, pp. 217218 , ibid.)? Também, a princípio, eles pareceriam estar distantes- enquanto pensadores que almejam uma liberdade-dos liberais que, como vimos, a temem-é a idéia que Arendt procura passar quando afirma que o "credo liberal" é um que diz que "quanto menos política mais liberdade" (Idem, p. 195) e que o liberalismo "não obstante o nome, colaborou para a eliminação da noção de liberdade do âmbito político" (Idem, p. 202). Mas será que essa idéia de que a liberdade seja um "estado"—algo que nos remete a uma paz encontrada-e não uma "relação"-algo vivo, pulsante, em aberto-não se aproxima de uma visão, como a liberal, que a quer, mas desde que dentro de determinados parâmetros, tais como seriam aqueles que definiriam, poderíamos dizer, uma "verdade" da liberdade? Os esforços de Arendt no 
aproximar o pensamento de Foucault desse tipo de discurso não esbarrariam justamente nessa mediação, nesse esquema que prevê uma sociedade civil e um Estado? Não mostrou ele que, como diz no resumo do curso Naissance de la biopolitique, "muito mais do que fazer da distinção Estado-sociedade civil um universal histórico e político que pode permitir interrogar todos os sistemas concretos, pode-se tentar ver nela uma forma de esquematização própria a uma tecnologia particular de governo"? ${ }^{230}$ E, nesse mesmo resumo, que entre a "sociedade política" e liberalismo-essa tecnologia governamental—há ligações estreitas na medida em que esse último tem procurado na "lei" uma regulação "não por um juridismo que lhe seja natural, mas porque a lei define formas de intervenções gerais de medidas particulares, individuais, excepcionais e porque a participação dos governados na elaboração da lei, num sistema parlamentar, constitui o sistema mais eficaz de economia governamental" 231 e que aquilo que recebe o nome de "vida política" é constituída pelo liberalismo-_"entendido como a questão do 'governar além da conta"”- “na medida em que a vida política existe no momento em que a prática governamental é limitada no seu excesso possível pelo fato de que ela é objeto público quanto a seu 'bem ou mal', quanto ao seu 'demais ou de menos"”?232 Foucault provavelmente diria que o problema no mundo, hoje, não é o de falta de política, mas de excesso dela—pelo menos dessa política que, ao se restringir à busca de

sentido de definir as condições em que uma verdadeira política deve se dar-lembrando sempre que, para ela, é aí, na política, somente, que mora uma liberdade, pois esta é a "razão de ser" da primeira—não caminham nesse sentido? Mas Arendt parece ignorar que a doutrina liberal e o exercício da políticacom seus respectivos espaços públicos e democráticos-, têm tido ao longo dos últimos 350 anos uma convivência extremamente cordial, pacífica e, até mesmo-como as prisões que Foucault mostra terem, desde o início, sido criticadas e objeto de inúmeras propostas de reforma - coroada por um sucesso. Elas têm agido em parceria; e Arendt parece não se dar conta disso, dando sempre ênfase ao presente como uma "experiência política" na qual vige uma tendência ao totalitarismo (Cf. idem, p. 195).

${ }^{230}$ FOUCAULT, Michel; "Naissance de la biopolitique", in $D E I I$, texto $\mathrm{n}^{\circ} 274$, p. 820.

${ }^{231}$ Idem, p. 822, grifo meu.

${ }^{232}$ Idem, pp. 822-823. 
consensos, não percebe que faz parte, é um elemento de uma tecnologia de poder chamada liberalismo.

Para Foucault, o que é necessário é uma nova política; como diz na passagem, acima citada ${ }^{233}$, de uma entrevista de 1984: uma "política como uma ética." E é precisamente essa entrevista, na qual dialoga com diversos teóricos da política, um dos momentos em que ficam mais claras as divergências em relação a Arendt e Habermas, essas duas referências atuais do pensamento político, da filosofia política. Seus interlocutores lhe perguntam se ele se consideraria um pensador "anti-político", na medida em que seu trabalho "parece querer estremecer" a idéia, defendida por esses dois pensadores, de que "o poder pode ser um consenso, uma esfera de intersubjetividade, uma ação comum", ao que ele responde que "a idéia de uma política consensual pode efetivamente, num determinado momento, servir seja de princípio regulador, seja sobretudo de princípio crítico em relação a outras formas políticas; mas eu não creio que isso liquide o problema da relação de poder" e dá o exemplo de iniciativas que têm tido lugar em países democráticos nas quais "se tenta fazer funcionar a justiça penal sob uma outra forma", dando a grupos ou a líderes dentro dos grupos "uma certa forma de autoridade que obedece a outras regras e a outros instrumentos": ela, diz ele, "produz efeitos que não são propriamente válidos na medida mesma em que não são estatais, que não passam pela mesma rede de autoridade."234 A conversa se aprofunda, então, quando um dos interlocutores volta a se referir à concepção arendtiana do poder, dizendo que essa autora vislumbra, por um lado, um poder que une as pessoas em torno de "coisas que elas não poderiam ter realizado de outro modo", que as liga "no sentido de que elas têm, em conjunto, uma capacidade da qual elas não disporiam se

${ }^{233}$ Cf. infra, nota ${ }^{\circ} 180$.

${ }^{234}$ FOUCAULT, Michel; "Politique et éthique: une interview", in DE II, texto nº 341, p. 1407. 
estivessem sozinhas" e que "supõe uma comunidade de pontos de vista, que pode também implicar relações de subordinação, porque uma das condições necessárias dessa ação comum pode ser a de ter cabeças, ou líderes" mas que não são relações de dominação; por outro lado, continua esse interlocutor, ela conceberia um outro aspecto do poder, que "põe em jogo, de maneira inequívoca, relações de dominação de certos indivíduos sobre outros." A pergunta que esse interlocutor então lhe faz é se ele reconheceria esses dois aspectos do poder ou somente o segundo, ao que Foucault retruca que, de fato, existe essa perspectiva arendtiana que dissocia as relações de poder das relações de dominação, mas que ele se pergunta se essa distinção não será "um pouco verbal" na medida em que "a rede constituída pelas relações de poder não permite tanto uma distinção categórica": "nada prova, por exemplo, que na relação pedagógica—isto é, na relação de ensino, essa passagem que vai daquele que sabe mais àquele que sabe menos - a autogestão seja aquilo que dá os melhores resultados; nada prova ao contrário que isso não bloqueie as coisas." ${ }^{235}$ A conversa avança mais um pouco, quando esse ou outro interlocutor então lhe diz que ainda que "empiricamente" ele "tenha razão" — e que o modelo do consenso seja utópico, uma mera "possibilidade ficcional"-, ainda assim "poderia em certo sentido ser melhor, mais saudável, mais libertador-associe a isso os valores positivos que quiser-se o consenso permanecesse para nós um objetivo a ser alcançado, muito mais do que um objetivo que nós rejeitamos e declaramos fora do nosso alcance." Foucault então diz que concorda, que esse seria o seu pensamento "desde que entendido como, digamos, princípio crítico". Alguém então, imediatamente, lhe pergunta: "princípio regulador?" e é na resposta a essa última pergunta que fica clara, em definitivo, a diferença de pontos de vista:

${ }^{235}$ Idem, p. 1408. 
"eu não diria talvez princípio regulador, isso seria ir muito longe porque, a partir do momento em que você diz princípio regulador, você admite que é justo em função daquilo que o fato deve ser organizado, dentro dos limites que podem ser definidos pela experiência ou pelo contexto. Eu diria muito mais que é talvez uma idéia crítica a se levar em conta permanentemente: perguntar-se qual é a parte de não-consensualidade que está implicada numa tal relação de poder, e se essa parte de não-consensualidade é necessária ou não, e então se pode interrogar toda relação de poder dentro dessa medida. Eu diria, no limite: não é necessário ser favorável à consensualidade, mas é necessário ser contra a não-consensualidade." 236

A busca da consensualidade enquanto princípio crítico e não regulador quer justamente dizer isso: que todas as relações de poder, de força, são passíveis de serem questionadas, de serem objetos de problematização, pontos em torno dos quais o diálogo, direto, imediato-que não passa pela figura obrigatória do "cidadão"—, entre governantes e governados, pode se dar; mas isso não quer dizer que, frente a esse diálogo, algumas dessas relações não possam se justificar, conseguir provar a sua necessidade. Ser contra a não-consensualidade, portanto, não implica em ser a favor da consensualidade, mas sim em ter sempre uma atitude crítica com relação a qualquer tentativa de querer conduzir as nossas condutas: essas tentativas terão, então, sempre, que mostrar a sua validade, a sua necessidade e, caso não consigam, eis então que se pode caminhar rumo a uma sua eliminação (por meio, inclusive, da sublevação); mas esse processo é um processo caso a caso—“é preciso observar todos os detalhes", ser "ao mesmo tempo extremamente prudente e empírico" diz Foucault quando fala sobre essa diferenciação entre o poder como dominação e o poder como esfera de intersubjetividade e consenso-; um processo em que a liberdade desses dois pólos, governantes e governados, está em jogo, e não uma tomada de partido, via de regra e às cegas, a favor da consensualidade, uma na qual essa seja um "princípio regulador", em que qualquer sinal de arbítrio é descartado de cara como não podendo pertencer—sob o risco de ter que se realizar uma "revolução", a única forma de revolta que os "cidadãos" possuem, 
para evitar isso-ao universo das "verdadeiras", "racionais" e "mais saudáveis" "relações de poder".

Isso posto, percebe-se que Foucault não compra a idéia de que o poder, enquanto força, seja algo a ser evitado, ou melhor, que a filosofia política deva se dedicar a encontrar uma nova definição para as relações de poder de tal modo a que a força possa ser completamente descartada, uma espécie de lavanderia para o poder, uma "máquina" que fizesse com que a força não mais tivesse lugar nas relações entre os homens. Foucault acha isso impossível e o diz com todas as letras quando, numa entrevista de 1984, diante de uma pergunta que lhe é feita sobre a possibilidade de que uma comunicação, nas sociedades, mais transparente, pudesse vir a tornar mais independentes os "jogos de verdade" — termo tão caro a Foucault, ao ponto de ele dizer, no início dessa entrevista, que o seu problema "sempre foi" o de "saber como o sujeito humano entrava nos jogos de verdade",237_ das "estruturas do poder":

"eis aí um problema importante que você coloca; eu imagino que seja um pouco pensando em Habermas que você o faz. Eu me interesso bastante naquilo que faz Habermas, eu sei que ele não está nada de acordo com o que eu digo-eu estou um pouco mais de acordo com o que ele diz—, mas há contudo algo que sempre me é problemático: é quando ele atribui às relações de comunicação esse lugar tão importante e, sobretudo, uma função que eu diria 'utópica'. A idéia de que poderia existir um estado de comunicação de tal ordem que os jogos de verdade pudessem nele circular sem obstáculos, sem constrangimentos e sem efeitos coercitivos me parece ser da ordem da utopia. É justamente não perceber que as relações de poder não são algo de mau em si, algo do qual seria necessário se livrar; eu creio que não existe sociedade sem relações de poder, se essas são entendidas como estratégias pelas quais os homens tentam conduzir, tentam determinar a conduta dos outros. O problema não é portanto o de tentar dissolvelas na utopia de uma comunicação perfeitamente transparente, mas de se dar as regras de direito, as técnicas de gestão e também a moral, o êthos, a prática de si, que permitirão, dentro desses jogos de poder, que se jogue com o mínimo possível de dominação."238

O poder para as relações sociais, assim como o desejo-com mostra uma parte importante da psicanálise_para o indivíduo, é algo de incontornável, algo diante do qual o melhor a fazer é assumir que ele existe e sempre existirá e que, somente a partir

${ }^{237}$ FOUCAULT, Michel; "L'éthique du souci de soi comme pratique de liberte", in DE II, texto no $356, \mathrm{p}$. 1527.

${ }^{238}$ Idem, pp. 1545-1546. 
daí é que se poderá passar a pensar as melhores formas de se lidar com ele e de utiliza-

lo a nosso favor. Desse modo, diz Foucault, na seqüência dessa entrevista:

“tem-me sido atribuída com freqüência essa idéia (de achar, à la Sartre, que 'O poder é o mal'), que está muito distante daquilo que eu penso. O poder não é o mal. O poder são jogos estratégicos. Sabemos muito bem que o poder não é o mal! Tome por exemplo as relações sexuais ou amorosas: exercer o poder sobre o outro, numa espécie de jogo estratégico aberto, onde as coisas podem se inverter, não é o mal; isso faz parte do amor, da paixão, do prazer sexual. Tomemos também algo que tem sido o objeto de críticas freqüentemente justificadas: a instituição pedagógica. Eu não vejo onde está o mal na prática de alguém que, num dado jogo de verdade, sabendo mais que o outro, diz-lhe o que é preciso fazer, lhe ensina, lhe transmite um saber, lhe repassa técnicas; o problema é muito mais saber como se vai evitar nessas práticas—onde o poder não pode não estar presente e onde ele não é mau em si—os efeitos de dominação que vão fazer com que um garoto seja submetido à autoridade arbitrária e inútil de um preceptor, um estudante ao jugo de um professor autoritário, etc. Eu acho que é necessário colocar essa questão em termos de direito, de técnicas racionais de governo e de êthos, de prática de si e de liberdade. ${ }^{, 239}$

É preciso estar, portanto, atento ao poder; é preciso inventar técnicas que nos permitam extrair dele benefícios, que nos ajudem a manejá-lo de forma a que nas relações onde ele se faz presente haja o menos possível de elementos contrários à nossa liberdade. E isso não vai acontecer se lhe voltarmos as costas, se lhe negarmos direitos de cidadania nas nossas sociedades, se fingirmos que ele não existe, fazendo de conta que ele pode ser eliminado. Mais do que uma consensualidade, eu diria, Foucault procurou uma conflitualidade, ou seja, que o maior número de conflitos possível venha à tona, que lá onde haja verdades muito bem assentadas, exista sempre uma voz para coloca-las em dúvida, problematiza-las, criticá-las, em suma, tornar o "fácil”, "difícill". É a isso o que, finalmente, ele vai dar o nome de crítica e que vai faze-lo, como veremos, se reaproximar de Kant. Mas, por ora, fiquemos com o conflito: na mesma entrevista, de 1981, a respeito da eleição de Mitterrand na França e da expectativa em relação ao seu governo, em que dá uma das mais lapidares definições do que seja a crítica_- "fazer a crítica é tornar difíceis os gestos fáceis demais",240_, Foucault nos

${ }^{239}$ Idem, p. 1546.

${ }^{240}$ FOUCAULT, Michel; "Est-il donc important de penser?", in DE II, texto nº 296, p. 999. 
fala, também, de conflito: "trata-se (nos processos onde ocorre a transformação política) de tornar os conflitos mais visíveis, de torna-los mais essências do que os simples confronto de interesses ou os simples bloqueios institucionais. Desses conflitos, desses confrontos deve surgir uma nova relação de forças da qual o perfil provisório será uma reforma."241 E algum tempo depois, por ocasião de uma entrevista com Émile Maire, então secretário-geral da C.F.D.T (Conféderation Française Democratique $d u$ Travail)—com a qual Foucault manteve uma estreita colaboração—, a respeito da situação na Polônia—onde havia sido decretado um estado de guerra—, quando seu interlocutor lhe diz que para ele—e a instituição que ele então lidera-

"a democracia é uma exigência superior, que impõe seus limites à luta de classes e rejeita notadamente que essa luta descambe na ditadura (dita 'provisória') do proletariado. O que se impõe a nós prioritariamente, o que nos situa claramente em relação ao marxismoleninismo, para não falar da sua ação prática, é a recusa total de toda ditadura, provisória ou não, de todos os procedimentos autoritários, mesmo em vistas da mudança social”,

Foucault, então, teoriza: “em relação ao velho dogma da luta de classes, não é o conflito em si que constitui para você(s) o motor mesmo da transformação. É a transformação que é primeira, é ela que implica um certo número de conflitos." ${ }^{242}$ O que leva à transformação, portanto, não é, para Foucault, o consenso ou a sua busca, mas o contrário: é a explicitação de diferenças e essa explicitação depende da capacidade que se tem de por em dúvida os consensos já existentes. Como ele diz sobre as reportagens de idéias, já mencionadas ${ }^{243}$ : "é justamente porque o mundo tem idéias (e porque ele as produz muito continuamente) que ele não é conduzido passivamente segundo aqueles que o dirigem ou aqueles que gostariam de ensiná-lo a pensar uma vez por todas." É o pensamento, portanto, e não a política, que carrega, por excelência, para Foucault, o

\footnotetext{
${ }^{241}$ Idem, p. 1000.

${ }^{242}$ FOUCAULT, Michel; “La Pologne et après?”, in DE II, texto n ${ }^{\circ} 334$, pp. 1319-1320.

${ }^{243}$ Cf. infra, nota $n^{\circ} 25$.
} 
germe da mudança, a esperança de liberdade, na medida em que é ele aquele elemento

capaz de levantar o maior número de conflitos. Assim, diz ele que

"é preciso se livrar da sacralização do social como a única instância do real e parar de considerar como vento essa coisa essencial na vida humana e nas relações humanas, isto é, o pensamento. O pensamento, isso existe, para além e para aquém dos sistemas e dos edifícios de discursos. É algo que freqüentemente se esconde, mas anima sempre os comportamentos cotidianos. Há sempre um pouco de pensamento mesmo nas instituições as mais estúpidas, há sempre pensamento mesmo nos hábitos mudos. (...) A crítica (e a crítica radical) é absolutamente indispensável para toda transformação. Pois uma transformação que permanecesse no mesmo modo de pensamento, uma transformação que não seria mais do que uma certa maneira de melhor ajustar o mesmo pensamento à realidade das coisas não seria senão uma transformação superficial. (...) Em compensação, a partir do momento em que se começa a não poder mais pensar as coisas como se as pensa, a transformação se torna ao mesmo tempo muito urgente, muito difícil e plenamente possível. (...) Portanto, não há um tempo para a crítica e um tempo para a transformação, não há aqueles que fazem a crítica e aqueles que transformam, aqueles que são enclausurados numa radicalidade inacessível e aqueles que são ultimamente obrigados a fazer as concessões necessárias ao real. De fato, eu creio que o trabalho de transformação profunda não pode se fazer senão no ar livre e sempre agitado de uma crítica permanente." 244

${ }^{244}$ FOUCAULT, Michel; "Est-il donc important de penser?”, op. cit., pp. 999-1000. 


\subsection{Capítulo 4: Modificações}

Eis o título que Foucault deu à primeira parte da sua Introdução a $O$ uso dos prazeres, volume II da História da sexualidade, de 1984, onde explica o que o levou a alterar o projeto inicial dessa História, que, inicialmente, iria se restringir à época moderna, quando, como vimos, surge a noção de sexualidade ${ }^{245}$. É também o título que dou a este capítulo, tomando-o emprestado, não para procurar mostrar que Focault tenha modificado o seu modo de pensar, ou de pensar acerca de certos autores e tradições filosóficas, numa espécie de capitulação perante os seus dizeres e diante das dificuldades que os conceitos que levantava lhe apresentavam, mas sim no sentido de que o que ele vinha pensando o levou—talvez o obrigou, em função da necessidade de um diálogo—a velhas leituras, a re-leituras que, por sua vez, revelaram novos autores lá mesmo onde estava o "velho". O que surge dessas re-leituras, portanto, não são os velhos Kant e Platão, mas outros Kant e Platão, dois autores que Foucault traz para a atualidade, inteiramente renovados, vivos, ricos, sem nenhum ranço de "fundadores" de tradições de pensamento, pais de tal ou qual filosofia; como se fossem eles mesmos aqueles que se modificam, para nós, por meio dos olhos de Foucault.

\subsubsection{Kant e a (atitude) crítica}

${ }^{245}$ Cf. infra, nota $\mathrm{n}^{\mathrm{o}} 100$. 
Desde que concebeu o conceito de governametalidade—ao longo, como vimos, do curso de $1978^{246}$ _, Foucault o fez ser acompanhado de uma espécie de antídoto: se o primeiro se define como uma "arte de governar" que implica uma "correta disposição" de coisas e- principalmente-de pessoas e de suas respectivas condutas, existe também uma outra "arte" que se vê surgir em concomitância-“defronte e como contrapartida, ou, antes, como parceira e adversária"-e que é a "arte de não ser assim governado" 247 , ou a "arte da insubmissão voluntária", da "indocilidade refletida" ${ }^{, 48}$; em suma, aquilo que Foucault vai entender como "crítica" ou "atitude crítica" e a cujo respeito ele vai dedicar uma importante conferência perante a Société française de philosophie, nesse mesmo e decisivo ano. Eis, então, o momento em que se inicia uma série de três artigos- - p primeiro deles sendo, na verdade, essa conferência e o segundo, uma aula—em que Foucault vai perseguir a noção de Esclarecimento, justamente essa noção que Kant havia procurado descrever num pequeno artigo de jornal—na verdade, uma resposta à pergunta que esse jornal lhe havia feito_-publicado em 1784: $O$ que é $o$ Esclarecimento?; uma série em que as palavras de Kant vão sendo ouvidas com cada vez mais atenção e apreço e que vai culminar em algo que um leitor de As palavras e as coisas—essa obra capital, de 1966 - jamais poderia sonhar: numa declaração de filiação, dada no contexto, bastante significativo ao meu ver, de um verbete que o próprio Foucault escreve, "no início da década de " 80 "249, sobre si mesmo para o Dicionário de Filósofos de Denis Huisman, sob o pseudônimo de Maurice Florence.

\footnotetext{
${ }^{246}$ Cf. infra, nota $n^{\circ} 136$.

${ }^{247}$ Cf. infra, nota $\mathrm{n}^{\circ} 215$.

${ }^{248}$ FOUCAULT, Michel; "Qu'est-ce que la critique? (Critique et Aufklärung)”, Bulletin de la société française de philosophie, ano 84, nº 2, Avril-Juin, 1990, p. 39.

${ }^{249} \mathrm{O}$ texto é publicado em 1984, mas não se sabe ao certo com que antecedência Foucault o escreveu.
} 
Diz, então, Foucault, iniciando o verbete: "Se Foucault de algum modo se inscreve na tradição filosófica, é na tradição crítica que é aquela de Kant e poder-se-ia chamar o seu empreendimento História crítica do pensamento." 250

Como é que surge, ou ressurge, Kant no pensamento de Foucault? Bom, justamente através disso a que Foucault dá o nome de atitude crítica e que ele diz acompanhar os passos da governamentalidade desde o seu berço:

"se lhe reconhecemos a esse movimento da governamentalização, da sociedade e dos indivíduos ao mesmo tempo, a inserção histórica e a amplitude que eu creio ter sido a sua, parece-me que se poderia colocar junto a isso aquilo que chamar-se-ia a atitude crítica (...) uma espécie de forma cultural geral, ao mesmo tempo atitude moral e política, forma de pensar, etc. e que eu chamaria tão simplesmente a arte de não ser governado, ou ainda, a arte de não ser governado desse jeito e a esse preço. E eu proporia então, como primeiríssima definição da crítica, essa caracterização geral: a arte de não ser assim governado." 251

Ora, o que ocorre, como diz um pouco mais à frente, é que

"aquilo que Kant descrevia como o Esclarecimento é justamente isso que eu tentava há pouco descrever como a crítica, como essa atitude crítica que se vê aparecer como atitude específica no Ocidente a partir, creio eu, disso que foi historicamente o grande processo de governamentalização da sociedade. ${ }^{, 252}$

E aí está: eis que Foucault está nos dizendo, está pensando ao menos, sobre a mesma pergunta que capturou a atenção de Kant, quase duzentos anos antes—o título da palestra é outro, O que é a crítica?, mas, como ele diz no começo, deveria ser um outro, atrevido demais, diz com ironia: $O$ que é o esclarecimento?, como revela no final. ${ }^{253}$

${ }^{250}$ FOUCAULT, Michel; "Foucault", in DE II, texto $\mathrm{n}^{\mathrm{o}} 345$, p. 1450, grifos do autor.

${ }^{251}$ FOUCAULT, Michel; "Qu'est-ce que la critique? (Critique et Aufklärung)”, op. cit., p. 38.

${ }^{252}$ Idem, p. 40.

253 "Para a questão da qual eu gostaria de lhes falar no dia de hoje, eu não lhe dei um título. O sr. Gouhier (que fez a apresentação) quis com indulgência dizer que é devido à minha estadia no Japão (e à pressa do seu retorno de lá). Deveras, é uma muito amável atenuação da verdade. Digamos que efetivamente, até esses últimos dias, eu não tinha ainda achado um título; ou melhor, havia um que me perseguia, mas que eu não quis escolher. Vocês verão por que: seria indecente" (Idem, p. 36), são as quase primeiras palavras de Foucault nessa ocasião, ao passo que a palestra, depois que a coincidência do Esclarecimento kantiano e a atitude crítica esteja consolidada, se encerra assim: "vocês vêem por que eu não poderia ter dado, ousado dar um título à minha conferência que teria sido: 'O que é o Esclarecimento?'” (Idem, p. 53) Nos outros dois escritos sobre o Esclarecimento, como veremos, o título dado é homônimo ao de Kant, tendo Foucault já "assumido" o seu "(indecente) atrevimento". 
E o que é que Foucault diz, nessa conferência, sobre o Esclarecimento?

Diversas coisas, todas pertinentes, como também veremos, ao debate sobre uma política, a uma atualidade política e filosófica, a uma prática questionadora do nosso presente, de nossa atualidade: nada de um espírito de historiador, ou museológico, reverente ou não a uma época tida como a das Luzes, pois, como disse alguns anos mais à frente, aos seus alunos no Collège de France,

"afinal de contas, parece-me de todo que o Esclarecimento, ao mesmo tempo como acontecimento singular inaugurando a modernidade européia e como processo permanente que se manifesta na história da razão, no desenvolvimento e instauração de formas de racionalidade e de técnica, a autonomia e a autoridade do saber, não é simplesmente para nós um episódio na história das idéias. Ele é uma questão filosófica, inscrita, desde o século XVIII, no nosso pensamento. Deixemos à sua piedade aqueles que querem que se guarde vivo e intacto a herança do Esclarecimento. Essa piedade é com certeza a mais tocante das traições. Não são os restos do Esclarecimento que se trata de preservar; é a questão mesma desse acontecimento e do seu sentido (a questão da historicidade do pensamento do universal) que é necessário manter presente e guardar no espírito como aquilo que deve ser pensado." ${ }^{254}$

O título que acabou dando a essa conferência, na verdade, é o mais propício—e toda a pudicícia em torno a repetir o título do artigo de Kant pode ser vista como uma mera firúla diante de uma platéia composta por filósofos, ou seja, de gente que, diferentemente dele (que se declara-de novo, provocativamente, pois filósofo ele certamente é-“quando muito" um "crítico" ${ }^{255}$ ), supostamente defende o respeito aos seus pares, ainda mais quando esses são da dimensão de um Kant—pois ele vai, nela, tratar da questão que surge no momento em que ele afirma que o Esclarecimento de Kant é a (sua) (atitude) crítica: então, se assim é, o que viria a ser a crítica de Kant, esse empreendimento titânico pelo qual esse filósofo alemão ficou (mais) conhecido? Em outras palavras, o que é, afinal, a crítica: é a crítica kantiana ou é a crítica foucaultiana?: essa é uma das chaves de leitura dessa conferência.

\footnotetext{
${ }^{254}$ FOUCAULT, Michel; “Qu'est-ce que les Lumières?”, in DE II, texto nº 351, pp. 1505-1506.

${ }^{255}$ FOUCAULT, Michel; "Qu'est-ce que la critique...”, op. cit., p. 41.
} 
E eis por que Foucault não se furta em adentrar, ainda que diga que não se permitiria faze-lo "diante de uma platéia equivalente de filósofos", numa análise da definição kantiana de crítica e do vínculo dessa, nesse pensamento, com a noção de Esclarecimento. Diz, a esse respeito, que Kant percebia haver uma "defasagem" "256 entre esses dois conceitos, algo que poderia ser uma oposição—na medida em que a sua crítica viria a ser aquela que, ao Esclarecimento, a essa "inservidão voluntária" ou "indocilidade refletida", marcada, como nos diz a sua insígnia (Aude sapere), pela ousadia e pela coragem, pergunta: "sabes bem tu até onde tu podes saber? reflete tu o quanto queiras, mas sabes bem tu até onde podes refletir sem perigo?"257—mas que acabava por ser uma espécie de parceria em que a crítica era situada por ele "dentro da sua empresa de desassujeitamento em relação ao jogo da verdade e do poder, como tarefa primordial, como prolegômeno a todo Esclarecimento presente e futuro, de conhecer o conhecimento." ${ }^{258}$ E seria precisamente essa defasagem, característica da concepção kantiana, que teria feito com que o entendimento a respeito do Esclarecimento tenha tido todo um desenvolvimento, nos séculos que se seguiram, que o afastou da atitude crítica, do seu aspecto de "pregação"- - quando Foucault fala desse aspecto, admite que é "um pouco ridículo" usar essa palavra—, de "apelo à coragem" ("em todo caso") ${ }^{259}$ e o fez se aproximar, meramente, do projeto crítico de Kant, dessa empreitada gigantesca de "conhecer o conhecimento", dando ênfase a um conhecimento que, por sua vez, se manifestou sob a tríplice forma de "uma ciência positivista", de um "sistema estatal que se apresentava a si mesmo como razão e como racionalidade

\footnotetext{
${ }^{256}$ Essa parece-me ser a melhor tradução para o termo décalage.

${ }^{257}$ Idem, ibid.

${ }^{258}$ Idem, ibid, grifos meus. No artigo de 1984, Foucault diz que, para Kant, a relação entre o artigo do Esclarecimento e as suas três críticas é uma na qual estas últimas são "de certa forma, o manual de instruções da razão que se torna maior de idade no Esclarecimento; e inversamente, o Esclarecimento é a era da Crítica." (FOUCAULT, Michel; "What is Enlightenment? (Qu'est-ce que les lumières?)", in DE II, texto ${ }^{\circ} 339$, p. 1386).

${ }^{259}$ FOUCAULT, Michel; "Qu'est-ce que la critique? », op. cit., p. 40.
} 
profunda da história" e um "estatismo", na forma de uma "ciência do Estado"260. E isso a tal ponto que a resposta dada por Kant em 1784 à questão $O$ que é o esclarecimento e o como ele situou, em face a ela, a sua empresa crítica, "essa interrogação sobre as relações entre Esclarecimento e Crítica",

"vai legitimamente tomar os ares de uma desconfiança ou em todo caso de uma interrogação cada vez mais suspeitante: de que excessos de poder, de que governamentalização, tanto mais incontornável quanto ela se justifica enquanto razão, essa razão em si não é ela mesma responsável historicamente?" ${ }^{261}$

Não há dúvida de que Foucault, ao falar dessa interrogação, está se referindo à Escola de Frankfurt. De fato, um pouco mais à frente, ao reconhecer que o problema do Esclarecimento é "afinal de contas o problema da filosofia moderna" e que o que ele está então à procura é, longe de um "espírito de polêmica ou de crítica", "marcar as diferenças e em certo sentido ver até onde se pode multiplicar, demultiplicar, demarcar umas com relação às outras, desencaixotar, se quiserem, as formas de análise desse problema" ${ }^{262}$, ele afirma uma "fraternidade" em relação a essa escola. Mas antes de fazer isso, faz notar que o destino dessa questão foi diferente na Alemanha do que aquele que teve na França. Na primeira, manteve um prestígio perante o pensamento social e filosófico, ao passo que, na segunda, não, fundamentalmente por motivos políticos-que fizeram com que, na França, houvesse toda uma vinculação do Esclarecimento à temática da Revolução, impedindo que aquela fosse pensada enquanto racionalização, tal como na Alemanha. Ora, o que Foucault está propondo nessa ocasião, perante a Sociedade Francesa de Filosofia é uma retomada dessa questão fundamental, ao seu ver: o Esclarecimento. E eis que ele propõe, como via para tal,

\footnotetext{
${ }^{260}$ Idem, p. 42. Foucault retoma essa idéia um pouco mais à frente na palestra, no momento em que se põe a pensar "muito vagamente, outras vias possíveis", dizendo que "essa questão do Esclarecimento desde Kant, e seguramente em função dessa defasagem entre Esclarecimento e crítica que ele introduziu, tem sido essencialmente colocada em termos de conhecimento, isto é, partindo-se disso que foi o destino histórico do conhecimento no momento da constituição da ciência moderna". (Idem, p. 47)

${ }^{261}$ Idem, p. 42.

${ }^{262}$ Idem, p. 45.
} 
algo que não é nada mais nada menos do que aquilo que ele vinha fazendo desde o seu primeiro livro: uma prática que "chamaríamos de histórica-filosófica" que consistiria em:

"fazer-se a própria história, de fabricar, como que por ficção, a história que será atravessada pela questão das relações entre as estruturas de racionalidade que articulam o discurso verdadeiro e os mecanismos de assujeitamento que a eles são ligados, questão na qual vê-se bem que ela desloca os objetos habituais e familiares aos historiadores na direção do problema do sujeito e da verdade, da qual os historiadores não se ocupam. Vê-se igualmente que essa questão insere o trabalho filosófico, o pensamento filosófico, a análise filosófica em conteúdos empíricos desenhados precisamente por ela. Daí, se quiserem, que os historiadores, diante desse trabalho histórico ou filosófico vão dizer: 'sim, sim, com certeza, talvez', em todo caso não é nunca efetivamente isso, o que é o efeito de embaçamento devido a esse deslocamento rumo ao sujeito e a verdade do qual eu falava. E que os filósofos, mesmo se eles não adquirem todos ares de galinhas d'angola ofendidas, geralmente pensam: 'a filosofia, apesar de tudo, é bem outra coisa', devendo-se isso ao efeito de queda, devido a esse retorno a uma empiricidade que não tem para si nem mesmo o ser garantida por uma experiência interior."263

A análise do problema do Esclarecimento, essa questão fundamental que Foucault está

dizendo que é preciso retomar, pode ser, portanto, equivalente à "questão das relações

dos poderes, da verdade e do sujeito"; e, faz ele notar, é uma questão que, ainda que

tenha surgido no âmbito da modernidade, pode ser aplicada indistintamente a qualquer

época $^{264}$. E essa questão é, igualmente, para Foucault, a questão da crítica-o que

permite que se entenda a autodenominação global do seu trabalho como "história crítica

do pensamento"一:

“...vemos que a morada da crítica é essencialmente o feixe de relações que amarram um ao outro ou uma às outras duas, o poder, a verdade e o sujeito. E se a governamentalização é deveras o movimento pelo qual se tratava na realidade mesma de assujeitar os indivíduos por meio de mecanismos de poder que se arrogam uma verdade, pois bem! eu diria que a crítica é o movimento por meio do qual o sujeito se dá o direito de interrogar a verdade sobre seus efeitos de poder e o poder sobre seus discursos de verdade",

já havia enunciado ele um pouco antes ${ }^{265}$.

${ }^{263}$ Idem, pp. 45-46.

264 "Não se tratará de dizer que os gregos do século V são um pouco como os filósofos do século XVIII ou ainda que o século XII já era uma espécie de Renascimento, mas de tentar ver sob que condições, ao preço de que modificações ou de que generalizações pode-se aplicar a qualquer momento da história essa questão do Esclarecimento", diz ele. (Idem, pp. 46-47)

${ }^{265}$ Idem, p. 39. 
Ou seja, o que Foucault faz nessa conferência é apresentar um resumo do seu trabalho até então-e de uma forma bem mais clara do que todas as tentativas anteriores, na medida em que começa a reconhecer que as relações de poder se dão no exercício de "dizeres verdadeiros" que se dirigem a um "sujeito", entendido como uma relação a si, como uma reflexividade de si sobre si mesmo-ao mesmo tempo em que mostra que esse mesmo trabalho pode servir, serve na formulação de uma resposta alternativa às respostas que a filosofia alemã vinha dando à questão do sentido do Esclarecimento. A esse respeito, diz Foucault, rumo ao fechamento da conferência, que a defasagem, acima apontada ${ }^{266}$, inaugurada por Kant, deu lugar a "um procedimento de análise que poderia se chamar um inquérito na legitimidade dos modos históricos do conhecimento", ou, em outras palavras um procedimento que carrega consigo a pergunta: "que falsa idéia o conhecimento faz de si mesmo e a que uso excessivo ele se encontrou exposto, a que dominação por conseguinte, ele se encontrou ligado?" Essa seria a questão, esclarecedora, de alguns "filósofos do século XVIII", bem como de Dilthey e de Habermas, frente à qual a "prática histórico-filosófica" que ele acabava de descrever viria a poder formular uma alternativa, uma opção na qual a abordagem "não seria mais o problema do conhecimento, mas o do poder" ${ }^{267}$ um poder, bementendido, que é percebido "sempre como relação num campo de interações", algo a ser pensado "dentro de uma relação indissociável com as formas de saber" e de tal maneira a ser visto "associado a um domínio de possibilidade e, por conseguinte, de reversibilidade, de reversão possível" e não como "dominação, mestria, a título de dado fundamental, de princípio único, de explicação ou de lei incontornável" ${ }^{268}$. A questão do Esclarecimento e dos efeitos de coerção que se fazem presentes nas positividades

\footnotetext{
${ }^{266}$ Cf. infra, nota $\mathrm{n}^{\mathrm{o}} 256$.

${ }^{267}$ Idem, p. 47.

${ }^{268}$ Idem, p. 52.
} 
onde se dá um conhecimento, poderia então deixar de diluir-se ou dissipar-se num "retorno à destinação legítima do conhecimento" e numa "reflexão sobre o transcendental ou quase-transcendental que o fixa", de deslocar-se em direção à crítica entendida no sentido kantiano, para fazer um "caminho inverso", que parte da "decisão de não ser governado", da "atitude ao mesmo tempo individual e coletiva de sair, como dizia Kant, da sua minoridade", "questão de atitude", questionando, então, o conhecimento e a sua relação com a dominação ${ }^{269}$. Ou seja, eu diria, uma forma de compreender o Esclarecimento como tendo uma preocupação primordial com a liberdade.

E, de fato, esse vai ser o diferencial dos dois outros escritos de Foucault sobre o Esclarecimento: a questão da liberdade; questão eminentemente política, mas que Foucault passa a aproximar de uma ética. Se na conferência sobre $O$ que é a crítica, o fundamental é o vínculo, a afirmação de que o Esclarecimento é a própria crítica (e vice-versa), o que Foucault mostra nesses dois outros momentos é que ele é o que carrega consigo, nos dias atuais, a possibilidade da liberdade-como que confirmando o que havia dito na entrevista a Didier Eribon, em $1981^{270}$, de que "não há um tempo para a crítica e um tempo para a transformação, não há aqueles que fazem a crítica e aqueles que transformam, aqueles que são enclausurados numa radicalidade inacessível e aqueles que são ultimamente obrigados a fazer as concessões necessárias ao real." A liberdade está ao alcance de cada um, aqui e agora, em cada instante que nos relacionamos com o outro, pois ela é relação.

Em ambos esses textos, Foucault se esforça em mostrar que Kant, no seu, definia o Esclarecimento como uma relação com o presente, com a "atualidade discursiva" que

${ }^{269}$ Idem, p. 53.

${ }^{270} \mathrm{Cf}$. infra, nota $\mathrm{n}^{\circ} 244$. 
é a atualidade de cada um que se proponha a adotar uma atitude passível de ser reconhecida como esclarecedora. Essa relação, por sua vez, configuraria uma modernidade, uma "atitude moderna", que não mais seria, como em outras épocas, um pensamento a respeito do presente em que esse é situado em relação a um passado, a uma Antigüidade clássica, num eterno exercício comparativo ou de filiação/desfiliação: pela primeira vez na história, diz ele na aula de 1983, "vê-se brotar uma nova maneira de colocar a questão da modernidade, não mais numa relação longitudinal com os Antigos, mas naquilo que se poderia chamar de uma relação 'sagital' com a sua própria atualidade."271 No texto de 1984, por sua vez, cabe a Baudelaire ser o exemplo de tal tipo de relação: ainda que a modernidade, nesse poeta, seja definida a partir do "movimento perpétuo", da vigência do "transitório, o fugaz, o contingente", diz Foucault, ser moderno para ele é "tomar uma atitude em relação a esse movimento", é ser capaz de capturar nele "qualquer coisa de eterno, que não está para além do instante presente, nem atrás dele, mas nele”. "Atitude voluntária, difícil”, prossegue, pois não se trata meramente de presentificar ou atualizar algo como a pintura, introduzindo fraques no lugar das vestes romanas, nem de sacralizar o momento que passa "para tentar mantê-lo ou perpetuá-lo" e nem de "recolhe-lo como curiosidade fugaz e interessante": o "homem moderno" de Baudelaire ocorre na figura do pintor Constantin Guys,

"em aparência, um flanêur, um colecionador de curiosidades; ele permanece como 'o último em tudo onde pode resplandecer a luz, ressoar a poesia, formigar a vida, vibrar a música, em tudo onde uma paixão pode pousar o seu olho, em tudo onde o homem natural e o homem de convenção se mostram em uma beleza bizarra, em tudo onde o sol clareia os gozos rápidos do animal depravado.' (...) Mas aí não deve haver enganos. Constantin Guys não é um flanêur; o que faz, aos olhos de Baudelaire, a pintura moderna por excelência é que na hora em que o mundo inteiro dorme, ele se põe a trabalhar, ele, e, nisso, o transfigura. Transfiguração que não é anulação do real, mas jogo difícil entre a verdade do real e o exercício da liberdade; as coisas 'naturais' então se tornam 'mais que naturais', as coisas 'belas' se tornam 'mais que belas' e as coisas singulares aparecem 'dotadas de uma vida entusiasta como a alma do autor'. Para a atitude de modernidade, o alto valor do presente é indissociável da teimosia em imaginá-lo, em imaginá-lo tal como

${ }^{271}$ FOUCAULT, Michel; “Qu'est-ce que les lumières?”, op. cit., p. 1500. 
ele não é e em transformá-lo não o destruindo, mas o captando naquilo que ele é. A modernidade baudelaireana é um exercício no qual a extrema atenção ao real é confrontada à prática de uma liberdade que ao mesmo tempo respeita o real e o viola." ${ }^{272}$

A esse tipo de relação com o presente Foucault também vai dar o nome-conforme encontramos no fim da aula de 1983, no texto de 1984 e na própria introdução a $O$ uso dos prazeres — de "ontologia do presente", ou "ontologia (histórica) de nós mesmos". Ela consiste, somente a título de reforço, "numa crítica daquilo de dizemos, pensamos e fazemos" 273 e o seu programa encontra-se detalhado no final do texto de 1984 , onde ambos os seus caracteres que a definem negativamente-enquanto uma rejeição à "chantagem" que exige uma tomada de partido "contra" ou "a favor" do Esclarecimento e enquanto "forma de reflexão filosófica" que se diferencia do humanismo—quanto positivamente-enquanto "êthos filosófico" que implica uma atitude ao mesmo tempo "limite" (ou situada neles, na reflexão sobre as "fronteiras") e "experimental" (evitando qualquer tentação de radicalizar ou globalizar) e que ele define como "um ensaio histórico-prático dos limites que nós podemos transpassar, e portanto como trabalho de nós mesmos sobre nós mesmos enquanto seres livres"274_são expostos.

Mas ambos os textos, igualmente, deixam claro que essa "atitude crítica" que define o Esclarecimento-queira que lhe seja dado o nome de "êthos filosófico", de “ontologia histórica de nós mesmos" de "atitude moderna" ou simplesmente de "relação

\footnotetext{
${ }^{272}$ FOUCAULT, Michel; “What is Enlightenment? ('Qu'est-ce que les lumières?')”, op. cit., pp. 13881389.

${ }^{273}$ Idem, p. 1392.

${ }^{274}$ Idem, pp. 1393-1394. Esse mesmo êthos filosófico será aquilo com o que Foucault, nesse texto e após retomar o envolvimento de Kant no esforço de questionar o presente, fechará seu discurso com palavras que se tornaram célebres e que têm um enorme poder de síntese: "essa atitude filosófica deve-se traduzir num trabalho de pesquisas diversas; essas possuem a sua coerência metodológica no estudo ao mesmo tempo arqueológico e genealógico de práticas vistas simultaneamente como tipo tecnológico de racionalidade e jogo estratégico das liberdades; elas possuem a sua coerência teórica na definição das formas historicamente singulares nas quais foram problematizadas as generalidades da nossa relação para com as coisas, para com os outros e para conosco mesmo. Elas possuem sua coerência prática no cuidado empenhado em submeter a reflexão histórico-crítica ao teste das práticas concretas. Eu não sei se hoje é necessário que se diga que o trabalho crítico implica ainda a fé nas Luzes; ele necessita, creio eu, sempre o trabalho sobre os nossos limites, isto é, uma paciente labuta que dá forma à impaciência da liberdade." (Idem, pp. 1396-1397)
} 
com o presente" — tem o seu horizonte desenhado na política, ou seja, não é nada que se veja restrito ao mero âmbito das artes, da cultura ou de qualquer outra atividade, como diríamos, etérea-na medida em que essa palavra se encontra vinculada ao que é acessório, mera "perfumaria". Que a liberdade da qual trata e à qual pacientemente "dá forma”, não é simplesmente a liberdade lírica do artista, do poeta ou do louco, mas a de todos, a do conjunto. Isso se evidencia quando, na aula de 1983, Foucault lembra que Kant, quinze anos após o seu artigo sobre $O$ que é o esclarecimento?, publicou um outro, $O$ conflito das faculdades, em que procura responder a uma outra-mas, intimamente relacionada- questão: o que é a revolução?-e mais especificamente, a Revolução Francesa. Para Foucault, esse segundo texto é uma espécie de continuação do primeiro: não havendo esquecido a interrogação do primeiro, Kant vai retoma-la por meio da interrogação desse outro e mais recente acontecimento. A Revolução para Kant é um sinal, o sinal necessário_-em forma de acontecimento—para dar a prova de que há uma causa que conduz a humanidade no sentido de um progresso constante; mas o que ele entende por Revolução, o que é importante nela para ele, diz Foucault, não são os grandes gestos, os grandes momentos e as grandes atitudes que a fazem ou fizeram, mas sim "aquilo que se passa na cabeça daqueles que não a fazem, ou em todo caso, que não lhe são os atores principais, é a relação que eles próprios têm com essa revolução na qual eles não são os agentes ativos." 275 Ela define-se, portanto, a partir de um entusiasmo, como uma disposição moral que se tornou manifesta num determinado momento da história e que prescinde do sucesso ou fracasso do movimento como um todo e de toda a sua "gesticulação". Essa disposição se consubstancia "no direito de todos os povos de se dar a Constituição política que lhes convenha e no princípio conforme ao direito e à moral de uma Constituição política tal que ela evite, em razão

\footnotetext{
${ }^{275}$ FOUCAULT, Michel; “Qu'est-ce que les lumières?”, op. cit., p. 1504.
} 
dos seus próprios princípios, toda guerra ofensiva." ${ }^{276}$, o que, por sua vez, para Foucault, "é o próprio processo do Esclarecimento, ou seja (isto quer dizer) que, a revolução é justamente aquilo que arremata e continua mesmo o processo do Esclarecimento, e é nessa mesma medida que também o Esclarecimento e a Revolução são acontecimentos que não podem mais ser esquecidos."277 Também, se evidencia, essa natureza política da "atitude crítica" no texto de 1984, num paroxismo de tal ordem que, nessa relação entre principal e acessório, entre o que é pensamento e o que é realidade "política", chega a haver uma inversão: é quando Foucault subscreve a injunção kantiana, presente no texto de 1784 , de que—sob um regime de um monarca esclarecido (no caso o eleito é Frederico da Prússia)—deve-se obedecer e "assim podereis conjeturar o tanto que quiseres" 278 e deixa claro que a liberdade está sendo jogada no ato de poder levantar questões, de conjeturar, de poder pensar e que o ato de governar pode ser, ele, uma mera "perfumaria".

Essa subscrição, a princípio tão contrária a tudo o que Foucault vinha dizendo e defendendo ao longo de toda uma vida—a princípio tão contrária à própria "arte da insubmissão voluntária" que ele havia levantado no texto sobre $O$ que é a crítica?-, não deve, contudo, assustar: ela não contradiz nada do que ele vinha pensando sobre a possibilidade da sublevação, por exemplo, da "arte de não ser assim governado". O que ocorre, como ele deixa claro logo em seguida, com o auxílio de Kant, é que o jogo entre governantes e governados é um jogo em que o que está implicado é a razão—daí que os

\footnotetext{
${ }^{276}$ Idem, ibid. Note-se como aqui, ainda, estão presentes os ecos da experiência vivida por Foucault na Revolução Iraniana

${ }^{277}$ Idem, ibid, grifo meu. Citando a Kant, na seqüência, Foucault diz: "'Esse acontecimento é importante demais, misturado demais aos interesses da humanidade e de uma influência vasta demais em todos os cantos do mundo para não ser mais relembrado às pessoas por ocasião de circunstâncias favoráveis e recordado no momento da crise de novas tentativas desse gênero, pois, num assunto tão importante para a espécie humana, é bastante necessário que a constituição seguinte atinja finalmente um certo momento de solidez que o ensinamento de experiências repetidas não se furtará a lhe fornecer em todos os espíritos."” (Idem, p. 1505)

${ }^{278}$ Cf. FOUCAULT, Michel; "What is Enlightenment?...”, op. cit., p. 1384.
} 
jogos de verdade e o dizer verdadeiro sejam estratégicos para qualquer análise dessa relação-e que essa, enquanto tal, possuiria dois tipos de uso. Um, privado, onde a razão é submissa e onde cabe a obediência: é o uso dela quando o homem é visto sob o ângulo de ele ser "um segmento particular dentro da sociedade", uma peça necessária na própria divisão social do trabalho, onde ele deve ocupar uma função. O outro, público, onde a razão é livre e onde esse mesmo homem, simultaneamente ao exercer o seu papel dentro do todo social, deve estar em condições—livre, portanto—de, publicamente, tudo questionar ${ }^{279}$, inclusive os pressupostos que regem o exercício desse papel que ele desempenha, desses "fins particulares". Nessas condições, em que "a audácia de saber pode se exercer em plena luz do dia", um governante qualquer, aquele que coordena os diversos usos privados, particulares da razão numa dada sociedade, não se sustentaria por muito tempo caso não se pautasse pelo universal, que é o âmbito desimpedido, irrestrito e loquaz do pensamento dos seus súditos. Uma vez asseguradas essas condições que dizem respeito ao uso público da razão, portanto, estaria assegurada uma relação entre governantes e governados com maior teor de liberdade.

Vê-se bem, a esta altura, que se está muito distante da concepção hobbesiana que nos diz que a liberdade individual dos súditos não tem nada em comum com a liberdade do Estado, que se poderia ser tão livre em Constantinopla, sob o gládio do paxá, quanto sendo um membro da república auto-governante de Lucca. Não se trata, no que diz respeito à liberdade de cada um, de se o governante de plantão permita tal ou qual ação; se trata de se cada um possui ou não o direito de publicamente questionar a forma como é governado, o como, por quem e a que preço: um tipo de questionamento que, partindo das relações mais locais pode chegar às mais gerais, demandando, por vezes, um

\footnotetext{
${ }^{279}$ Essas seriam as condições para haver Esclarecimento, pois, como afirma Foucault, ele ocorre quando "há superposição do uso universal, do uso livre e do uso público da razão." (Idem, p. 1385)
} 
completo rearranjo de forças, uma substituição irredutível, sem concessão, dos jogadores. E isso, certamente, é muito mais fácil de ter lugar numa república autogovernante do que sob um paxá, até porque esse último sempre saberá que é, muito provavelmente, a sua própria vida aquela que estará em jogo por hora dessa eventual substituição. Um Estado livre é muito mais propenso a criar as condições para que se dê um uso desimpedido, independente, da razão, um uso em que o mais obediente dos súditos tenha o direito de levantar a voz e conjeturar a respeito do que quer que seja; é um Estado muito mais propenso a lidar com a periculosidade do pensamento e do discurso, com a sua inquietude e a sua recalcitrância, de tal modo que talvez somente nele e com ele possam esses se dar. Sob esse ponto de vista, liberdade individual e liberdade coletiva estão, sim, como queriam os teóricos neo-romanos da liberdade, intimamente vinculados, a diferença sendo, quem sabe, somente uma questão de ênfase, pois para Foucault, na esteira de Kant, o que é vital, aquilo sem o qual não teria sentido nenhum falar em liberdade, está na relação que se mantém consigo mesmo e com os outros $^{280}$ e no quanto há nelas de espaço, de abertura, para poder se experimentar, ou inventar, ou meramente imaginar ou sonhar, conjeturar, o novo. O principal está, para Foucault, no êthos, nesse feixe de possibilidades em torno à criação de novas formas de se relacionar consigo e com os outros e não naquilo que toda uma tradição do pensamento político vem entendendo ser o problema primordial da política: o Estado. O problema, então, não seria que ética poderia ser mais propícia a uma política, mas que política estaria mais de acordo com uma ética.

\footnotetext{
${ }^{280}$ Outra forma, talvez, de se chamar as relações entre sujeito, verdade e poder, a "morada da crítica", como vimos acima (cf. nota $\mathrm{n}^{\circ} 265$ ).
} 


\subsubsection{Platão e o cuidado de si}

Numa visita que fez ao Japão, em 1978, Foucault, diante de um grupo de monges zen-budistas de um mosteiro ao qual foi convidado a visitar, declarou que "se uma filosofia do futuro existe, ela deve nascer fora da Europa ou bem ela deve nascer em conseqüência de encontros e percussões entre a Europa e a não-Europa"281. Ele tinha sido instigado por um dos seus interlocutores a respeito da "filosofia européia", e respondeu dizendo que enxergava nela uma exaustão que acreditava estar ligada à morte do imperialismo - um tema não muito distante, como vimos, daquilo que o levou a acompanhar e escrever sobre a Revolução Iraniana. Mas o que lhe interessava pessoalmente naquela ocasião não era tanto essa "crise" da filosofia, mas a pastoralidade: tratava-se de verificar até que ponto ela estaria presente ou não em outras tradições ascéticas que não o catolicismo. Era uma preocupação, portanto, com a governamentalidade, como se Foucault estivesse à cata de experiências que estivessem para além dela, fora do seu alcance. Isso é uma chave importante para que possamos entender o que foi que o levou na direção da antiguidade clássica, período coberto, junto com a época helenística, pelos dois volumes da História da sexualidade lançados em 1984-que tanto surpreenderam o seu público, acostumado ao seu trato da época moderna.

${ }^{281}$ FOUCAULT, Michel; "Michel Foucault et le zen: un séjour dans un temple zen", in $D E I I$, texto $\mathrm{n}^{\circ}$ 236 , p. 623. 
Até o presente momento, as transcrições dos cursos de 1980 e 1981, intitulados, respectivamente, Do governo dos vivos e Subjetividade e verdade, ainda não foram publicadas. O que se sabe a seu respeito é o que Foucault escreveu como resumo deles, obrigação que ele tinha perante o Collège de France, ao final de cada ano ${ }^{282}$. $\mathrm{O}$ primeiro curso é um estudo sobre a constituição do sujeito dentro do cristianismo, cobrindo um período histórico que começa no século II de nossa era e se estende até a Idade Média, inquirindo aquilo que teria toda a cara de constituir os primórdios de uma relação consigo baseada na renúncia, uma relação em que se abre mão da prerrogativa de conduzir a si mesmo para passar a ser conduzido—e que marca o homem moderno, de acordo com tudo o que Foucault havia se esforçado em demonstrar até aquele momento $^{283}$. Esse material certamente seria aquele que ele usaria na escrita de $A s$ confissões da carne, o quarto volume, impublicado em função de sua morte, da História da sexualidade; mas o que realmente importa é que não foi esse o material que o empolgou de imediato, a ponto de ter ele se lançado na sua escrita, uma vez consolidado o conhecimento a seu respeito. Houve, na virada do curso de 1980 para o de 1981, uma extensão de interesse temporal rumo ao período helenístico e à antiguidade clássica que o conduziu a algo que ele julgou provavelmente mais importante, a ponto de merecer

${ }^{282}$ Cf. FOUCAULT, Michel; "Du gouvernement des vivants" e "Subjetivité et vérité", in $D E I I$, textos n $289 \mathrm{e} \mathrm{n}^{0} 304$.

${ }^{283}$ No começo do resumo desse curso, por exemplo, Foucault diz que se tratou, ao longo dele, de responder à pergunta "como se dá que, na cultura ocidental cristã, o governo dos homens demanda, da parte daqueles que são dirigidos, além dos atos de obediência e submissão, 'atos de verdade' que têm a particularidade de que não somente o sujeito é instado a dizer com correção (dire vrai), mas a dizer com correção a respeito de si mesmo, de suas faltas, de seus desejos, do estado de sua alma, etc.? Como se formou um tipo de governo dos homens no qual não se requer simplesmente que obedeçamos, mas que manifestemos, enunciando-o, aquilo que somos." (FOUCAULT, Michel; "Du gouvernement...", op. cit. p. 944.) Com o tempo, Foucault passaria a dar-se conta de que, no que diz respeito a aspectos práticos das condutas sexuais, a austeridade que marca um tal tipo de renúncia já estaria presente num contexto anterior, "pagão"- constatação essa que está no cerne do que é exposto nos volumes da História da sexualidade que ele ainda viria a publicar. 
ser escrito primeiro. Esse algo é o cuidado de si, uma tradição cultural ${ }^{284}$ que Foucault mostra ter tido uma história de aproximadamente mil anos, uma história na qual a obra e o pensamento de Platão constitui um dos principais momentos, um momento de afirmação de um entendimento a seu respeito que viria a sofrer progressivas e sutis alterações de sentido ao longo dos séculos que lhe seguem. Em outras palavras, um marco, uma espécie de pedra fundamental; e o que tornou a descoberta dessa tradição cultural algo tão importante para Foucault parece passar, como veremos, pela convergência que o conteúdo desse cuidado de si, na sua versão platônica, tem com a atitude crítica, da qual Foucault começou, como vimos, a falar a partir de $1978^{285}$.

\footnotetext{
${ }^{284}$ Essa caracterização do cuidado de si encontra-se no curso de 1982 -dedicado integralmente à sua "elucidação"-, mas somente após ela também ter sido apresentada como uma "noção (...) bastante complexa e rica, muito freqüente também, e que perdurou longamente em toda a cultura grega" (FOUCAULT, Michel; A hermenêutica do sujeito; São Paulo, Martins Fontes, 2004, p. 4) e como uma "fórmula" (Idem , p. 5): ela aparece no momento em que Foucault adentra a sua análise na obra de Platão-no Alcibíades, mais especificamente—e diz que "se é verdade que é com Sócrates (...) que assistimos à emergência do cuidado de si na reflexão filosófica, não devemos contudo esquecer que o princípio 'ocupar-se consigo'-como regra, como imperativo, imperativo positivo do qual muito se espera-não foi, desde a origem e ao longo de toda a cultura grega, uma recomendação para filósofos, uma interpelação que um filósofo dirigia aos jovens que passam pela rua. Não foi uma atitude intelectual, nem um conselho dado por velhos sábios a alguns jovens demasiado apressados. Não, a afirmação, o princípio 'é preciso ocupar-se consigo mesmo' era uma antiga sentença da cultura grega. Uma sentença, em particular, lacedemônia" e "quando Sócrates retoma a questão da epiméleia heautôu e a formula, retoma-a a partir de uma tradição." (Idem, pp. 41-42) Mais à frente, esse entendimento é reforçado quando é analisado o aspecto técnico desse cuidado, ou das práticas que perfazem uma 'tecnologia de si': "não se deve esquecer e é preciso reter sempre na memória, que esta exigência de ocupar-se consigo, esta prática-ou antes, o conjunto de práticas nas quais vai manifestar-se o cuidado de si-enraíza-se, de fato, em práticas muito antigas, maneiras de fazer, tipos e modalidades de experiência que constituíram o seu suporte histórico, e isto bem antes de Platão, bem antes de Sócrates.” (Idem, pp. 58-59)

${ }^{285}$ Essa descoberta está registrada já no curso de 1981, como atesta o seu resumo. Nele, Foucault enuncia que ora se inicia "uma investigação sobre os modos instituídos do conhecimento de si e sobre a sua história" e que essa investigação consiste em questionar "quais os procedimentos, tal como existem em todas as civilizações, que são propostos ou prescritos aos indivíduos para fixar sua identidade, mantê-la ou transformá-la em função de um certo número de fins, e isso graças a relações de domínio de si sobre si ou de conhecimento de si por si. Em suma, trata-se de re-situar o imperativo do 'conhecer-se a si mesmo', que nos parece tão característico de nossa civilização, dentro da interrogação mais vasta e que lhe serve de contexto mais ou menos explícito: o que fazer de si mesmo? que trabalho operar sobre si? como 'governar-se' exercendo ações onde se é si mesmo o objetivo dessas ações, o domínio onde elas se aplicam, o instrumento ao qual elas recorrem e o sujeito que age?" (FOUCAULT, Michel; "Subjectivité et vérité", op. cit, p. 1032). Esse resumo evidencia, também, a importância que Foucault já reconhecia a Platão e ao seu Alcibíades-como "ponto de partida" (Idem, ibid) para essa investigação_-; e, por último, é um lugar importante para o entendimento de como toda essa nova linha de investigação se vincula à temática da governamentalidade e à procura de ir além dela, de lhe procurar uma alternativa: "a história do 'cuidado' e das 'técnicas' de si seria portanto uma maneira de fazer a história da subjetividade: não mais, entretanto, através das separações entre loucos e não-loucos, doentes e não-doentes, delinqüentes e
} 
Os volumes II e III da História da sexualidade podem ser lidos como a história dessa tradição cultural do cuidado de si naquilo que diz respeito às condutas sexuais. $\mathrm{O}$ volume III intitula-se $O$ cuidado de si, mas não é propriamente nele que o conjunto de conceitos que conformam essa tradição é explicitado: isso já se encontra no volume II, O uso dos prazeres, onde Foucault, diante das evidências históricas que apontam para a prescrição de práticas de austeridade sexual numa época "pagã", prévia ao cristianismo—onde elas podem ser facilmente reconhecidas-, diz que é necessário operar "todo um recentramento" e se perguntar como é possível que, nesse momento "pagão", "o comportamento sexual (...) tenha sido refletido como domínio de experiência moral" ${ }^{286}$ para, então, se entregar a uma digressão, que compõe toda uma parte, a última, do capítulo introdutório, a respeito de quais seriam os elementos de que é composta uma moral. Foucault não o explicita, mas tudo o que ele especula a respeito da moral, nessa parte da sua Introdução, pode ser visto como aquilo a partir do qual se pode entender o que é o cuidado de si-o quadro, os pressupostos teóricos, diríamos hoje, para o entendimento de algo como o cuidado de si. "Para que uma ação seja chamada de moral", diz ele, não basta que ela se reduza

"a um ato ou a uma série de atos conformes a uma regra, uma lei ou um valor. Toda ação moral, é verdade, comporta uma relação real onde ela se efetua e uma relação ao código ao qual ela se refere; mas ela implica também uma certa relação a si; esta não é simplesmente 'consciência de si' mas constituição de si mesmo como 'sujeito moral', na qual o indivíduo circunscreve a parte dele mesmo que constitui o objeto dessa prática moral, define sua posição em relação ao preceito que ele segue, fixa para si um certo modo de ser que valerá como realização moral de si mesmo; e para fazer isso, ele age sobre si mesmo, empreende de se conhecer, se controla, se testa, se aperfeiçoa, se transforma." 287

não-delinqüentes, não mais através da constituição de campos de objetividade científica dando lugar ao sujeito vivente, falante e que trabalha; mas através da colocação no mundo e transformação dentro de nossa cultura das 'relações a si mesmo', com sua armadura técnica e seus efeitos de saber. E poderíamos, desse modo, retomar sob um outro aspecto a questão da 'governamentalidade': o governo de si por si na sua articulação com as relações a outrem (tal como o encontramos na pedagogia, nos conselhos de conduta, na direção espiritual, na prescrição de modelos de vida, etc.).” (Idem, p. 1033)

${ }^{286}$ FOUCAULT, Michel; Histoire de la sexualité--L'usage des plaisirs; op. cit., p. 35.

${ }^{287}$ Idem, p. 40. 
É possível, a partir disso, fazer a história da "maneira como os indivíduos são chamados a se constituir como sujeitos de conduta moral", ou seja,

"dos modelos propostos para a instauração e o desenvolvimento das relações a si, para a reflexão sobre si, o conhecimento, o exame, o deciframento de si por si, as transformações que se procura operar sobre si mesmo. É isso o que se poderia chamar uma história da 'ética' e da 'ascética', entendida como história das formas da subjetivação moral e das práticas de si que são destinadas a assegura-la."288

E esse tipo de história, mais do que uma história dos códigos, é o mais adequado para entender a reflexão moral da Grécia Antiga e do período greco-romano, pois esses dois períodos possuiriam uma "moral orientada em direção à ética", uma moral "muito mais orientada para as práticas de si e à questão da askesis, do que da codificação das condutas e da definição estrita do permitido e do proibido." ${ }^{289}$ Na medida em que, como afirma logo em seguida, $O$ uso dos prazeres é dedicado a "marcar alguns traços gerais que caracterizam a maneira pela qual o comportamento sexual foi refletido pelo pensamento grego clássico como domínio de apreciação e de escolha moral”290, pode se dizer que ele é a história de como se deu um dos aspectos, o sexual, do cuidado de si ao longo desse período, clássico, da sua vigência e que o cuidado de si é uma moral, historiada, no seu aspecto sexual, ao longo dos dois volumes da História da sexualidade publicados em 1984.

O capítulo seguinte de $O$ uso dos prazeres, intitulado "A problematização moral dos prazeres" é composto por quatro sub-partes e se propõe a promover a distinção de "alguns traços gerais que serviram de quadro geral"291 aos quatro tipos principais de estilização da conduta sexual que ele irá analisar ao longo do livro: a Dietética, a Econômica, a Erótica e a Filosofia. Ele quer determinar os "aspectos gerais" sob os quais os antigos se preocuparam a respeito dos comportamentos sexuais, "a forma geral

\footnotetext{
${ }^{288}$ Idem, p. 41.

${ }^{289}$ Idem, p. 43.

${ }^{290}$ Idem, pp. 44-45.

${ }^{291}$ Idem, p. 50.
} 
da interrogação moral que eles se colocaram em relação aos aphrodisia"292. E é dentro desse exercício—envolvendo os conceitos de aphrodisia, khrêsis, enkratéia e de sophrosyne — que a noção de cuidado de si, no entendimento que ela recebe por parte de Platão, aparece por primeira vez; mais precisamente, isso ocorre ao longo da descrição do conceito de enkratéia, a "atitude" que é "necessária à moral dos prazeres e que se manifesta no bom uso que deles fazemos" $" 293$ : essa atitude implica uma "forma ativa de domínio sobre si, que permite resistir ou lutar e assegurar a dominação de si no domínio dos desejos e dos prazeres" 294 , podendo ser descrita como inserida numa "relação agonística", onde se demanda uma "atitude polêmica consigo mesmo", característica de uma "ascese", ou seja, de um treinamento, uma preparação para a luta; ora, essa necessidade de exercício polêmico consigo, ascético, será associada, relata Foucault a respeito de Platão, à "necessidade de se ocupar de si mesmo" pois "a epimeleia heautôu, a aplicação a si, que é uma condição prévia para poder se ocupar dos outros e de dirigilos, comporta não somente a necessidade de conhecer (de conhecer o que se ignora, de conhecer que se é ignorante, de conhecer o que se é), mas de se aplicar efetivamente a si e de exercitar a si mesmo e se transformar."295

Mas o vínculo mais estreito estabelecido em $O$ uso dos prazeres com o cuidado de si na acepção que lhe é dada por Platão encontra-se na análise feita por Foucault do conceito-chave de khrêsis. Esse é o conceito ao qual, como mostra Foucault n'A hermenêutica do sujeito-curso do ano de 1982 que recebeu recente tradução ao

\footnotetext{
${ }^{292}$ Idem, p. 51. Quanto a esses aphrodisia, encontramos duas definições mais à frente: "são gestos, atos, contatos, que proporcionam uma certa forma de prazer" (Idem, p. 55) e "atos requeridos pela natureza, associados por ela a uma prazer intenso e aos quais ela conduz por meio de uma força sempre suscetível de excesso e de revolta." (Idem, p. 123)

293 Idem, p. 86.

294 Idem, p. 87.

295 Idem, pp. 98-99.
} 
português, após sua publicação em francês no ano de $2001^{296}$ _, Platão recorreu, no Alcibíades, para explicar a seu interlocutor o que exatamente é o cuidado de si. ${ }^{297}$ Como fazer uso dos prazeres_-cuja "vivacidade", força (energeia) e tendência natural para o excesso é algo que se lhes reconhece, mas que não chegam a ser vistos como um "mal",298_, de forma a que eles não nos dominem? Que condições e modalidades de uso correspondem a uma "arte" 299 de tal magnitude? Como se configura um estilo no que diz respeito a esse uso-muito mais do que uma codificação que lhe diga respeito, posto que, como diz mais adiante, "a reflexão moral da Antigüidade a respeito dos prazeres não se orienta nem na direção de uma codificação dos atos nem na de uma hermenêutica do sujeito, mas na direção de uma estilização da atitude e de uma estética da existência" ${ }^{, 300}$ ? Eis as questões a que dá resposta o sub-capítulo de $O$ uso dos prazeres dedicado à khrêsis. Nele, lemos que esse estilo compreende três estratégias: a da necessidade, a do momento e a do status; e a descrição em detalhe que Foucault faz de cada uma delas talvez seja o lugar, por excelência, onde mais claramente aparece o interesse profundo que ele passou a nutrir pela obra de Platão, pela figura de Sócrates e pela tematização de ambos do cuidado de si.

\footnotetext{
${ }^{296}$ Cf. FOUCAULT, Michel; A hermenêutica do sujeito; op cit.

${ }^{297}$ Esse conceito, inclusive, é o que se encontra no título desse volume-o uso dos prazeres, khrêsis aphrodision-e diz respeito, como veremos, ao "fazer uso" de algo. O recurso a esse conceito no Alcibíades será tratado em maior profundidade um pouco mais adiante, mas podemos adiantar, já, que ele se encontra na aula de 13 de janeiro (primeira e segunda horas) e na primeira hora da aula do dia 20 de janeiro (pp. 55-132).

${ }^{298} \mathrm{Cf}$. a esse respeito toda a segunda parte do sub-capítulo dedicado aos aphrodisia (pp. 65-71 da edição francesa) de $O$ uso dos prazeres.

${ }^{299}$ O termo é usado não só nesse sub-capítulo (cf. FOUCAULT, Michel; Histoire de la sexualité, vol. II..., op. cit., p. 77), mas no final do capitulo "A problematização moral dos prazeres", quando Foucault sintetiza o que disse, ao longo dele, a respeito desses quatro conceitos que compõem a "forma geral" dessa "interrogação moral" dos antigos a respeito dos prazeres (cf. Idem, p. 123).

${ }^{300}$ Idem, p. 125. A pergunta sobre o estilo encontra-se no início do sub-capitulo sobre a khrêsis (cf. Idem, p. 72).
} 
Um princípio $^{301}$ de regulação dos prazeres, mostra-nos Foucault, de acordo com essa "ética"—ou "moral" que se orienta em sua direção—é o da necessidade: não se deve fazer uso dos aphrodisia a não ser quando surge a sua necessidade; ou melhor: o seu bom uso, o seu uso ótimo, vincula-os a um chamado da natureza, ocasião na qual essa segunda-e a urgência que ela carrega-, como no caso de Sócrates diante do prazer proporcionado por uma refeição—no relato que dele faz Xenofontes e representada por uma fome que foi paciente e naturalmente alimentada-, cai como um tempero que acentua o sabor. Esse modo de uso, que não é em absoluto um no qual se busque uma anulação do $\operatorname{prazer}^{302}$, "permite um equilíbrio na dinâmica do prazer e do desejo" 303 , uma vez que se trata de manter o primeiro por meio da "necessidade" que o segundo "suscita". Ao se fixar o limite da necessidade para o desejo, evita-se que "essa força natural entre em sedição e usurpe um lugar que não é o seu" ${ }^{304}$ e, assim, caminhase para uma condição temperante.

A segunda estratégia do uso dos prazeres de forma temperante é a do momento oportuno, o kairós; ela consiste numa "arte do momento" que indica, àqueles que nela se exercitam, o momento, que pode ser determinado "segundo diversas escalas", em que é e em que não é conveniente fazer uso dos prazeres. E novamente é o exemplo de Sócrates-de acordo, novamente, com Xenofontes—que é usado por Foucault para mais claramente explicitar esse princípio e essa estratégia: trata-se da tematização da questão do incesto que é por ele vista como passível de punição pelos deuses, mas não

\footnotetext{
${ }^{301}$ Eis o termo que se encontra na abertura desse sub-capítulo, quando Foucault diz "De que maneira obter o prazer "como se deve? A que princípio referir-se para moderar, limitar, regular essa atividade?" (Idem, p. 72).

${ }^{302}$ Isso está afirmado não só nesse sub-capítulo (idem, p. 75), mas também no seguinte, quando Foucault lembra da "famosa prova de Sócrates" na qual ele não se deixa seduzir por Alcibíades, mas que não o mostra "'purificado' de todo desejo a respeito dos moços" e compara essa relação para com o desejo com a austeridade cristã: "um tal prova, os cristãos a condenam pois ela atesta a presença resoluta, e para eles imoral, do desejo." (Idem, p. 94)

${ }^{303}$ Idem, p. 76.

${ }^{304}$ Idem, ibid.
} 
porque fira a um preceito religioso ou social e sim porque nele se misturam "a contratempo a semente de genitores dos quais um é necessariamente muito mais velho que o outro", revelando, assim, um "desconhecimento do tempo",305.

A última condição para um bom uso dos prazeres é a de que se deve, nele, levar em conta o status daquele que os prática, não podendo, nessa ordem, ser adotada um atitude que leve, como no cristianismo, a princípios gerais, ou universais, de conduta. Em outras palavras, os critérios que regem o julgamento sobre o uso correto ou não dos prazeres, devem ser diferenciados segundo o seu usuário e segundo o lugar, de liderança ou de obediência, que ele ocupe na cidade, os mais rígidos cabendo aos primeiros. Foucault recorre novamente, desta feita, a Platão e à sua República chamando a atenção para o fato de que é verdade que

"ele quer dar ao Estado inteiro a virtude da temperança; mas ele não entende por isso que todos serão igualmente temperantes; a sophrosyne caracterizará o Estado onde aqueles que devem ser dirigidos obedecerão, e onde aqueles que devem comandar comandarão efetivamente: encontrar-se-á portanto uma multiplicidade de 'desejos, de prazeres e de penalidades', dizendo respeito às crianças, às mulheres, aos escravos, bem como a uma massa de gente sem valor; 'mas os desejos simples e moderados que, sensíveis à razão, se deixam guiar pela inteligência e pela opinião justa', só poderão ser encontrados 'em um reduzido número de pessoas, aqueles que acrescentam ao mais belo natural, a mais bela educação'. No Estado temperante, as paixões da multidão viciosa são dominadas pelas 'paixões e a inteligência de uma minoria virtuosa'.",306

Pois bem, esses três princípios, que dizem respeito à khrêsis aphrodision, a um uso correto, adequado, livre, soberano, dos prazeres, podemos relaciona-los às três características fundamentais do cuidado de si conforme a sua acepção platônica, tal qual nos é mostrado ao longo não somente da leitura que Foucault faz, em A hermenêutica do sujeito, do Alcibíades de Platão, mas da análise que segue a essa leitura e que mostra como foram sendo rompidos, de forma gradual, esses três pilares que sustentavam tal entendimento particular dessa noção.

${ }^{305}$ Idem, p. 80.
${ }^{306}$ Idem, p. 83 
Foucault dedicou, no curso de 1982, toda uma aula e a metade de duas outras para destrinchar o cuidado de si tal como ele ocorre na obra de Platão, processo esse no qual o diálogo Alcibíades estabelece o diapasão e o enredo. Nele, conforme nos mostra Foucault, temos a situação de um homem de meia idade, Alcibíades, que, sendo filho de uma elite política e tendo tido uma juventude em que, dada a sua beleza, foi muito cortejado— - de acordo com algo que costumava acontecer então-pelos mais velhos—à exceção de Sócrates—chega a uma idade em que começa a perder os atributos físicos que o marcavam e passa a alimentar, segundo o que revela a Sócrates quando este, finalmente, o interpela, uma vontade de governar sobre a cidade de Atenas. Sócrates vai paulatinamente lhe mostrando que ele não tem a menor noção—ou uma noção completamente errada—daquilo que é necessário para realizar tal ambição e que, mesmo se ele chegasse a convencer os seus concidadãos a respeito da sua liderança, o seu governo estaria fadado ao fracasso em função do maior poderio demonstrado, em termos de qualidade da educação proporcionada e do volume de riquezas possuídos, pelas cidades e pelos impérios vizinhos a Atenas. Seria necessário um diferencial para poder enfrentar tal condição de inferioridade e eis onde entra o cuidado de si: para bem governar, para ser um bom governante a um ponto tal de poder compensar as fraquezas estruturais de Atenas, é necessário que aquele que, como Alcibíades, tem tal pretensão, saiba cuidar de si. Essa é a condição para poder governar os outros cidadãos atenienses de forma a poder fazer frente a essa conjuntura desfavorável, de ter alguma chance de sucesso diante dela. E o que é esse cuidado de si de que Sócrates fala a Alcibíades? Para responder a essa pergunta, Sócrates a desmembra em duas: o que é esse "si"—ou o “eu”, caso se esteja pensando em si mesmo—e o que é esse cuidado?—e, acrescenta Foucault, num comentário a respeito do diálogo, “na sucessão dessas duas questões (...) 
trata-se de responder a uma única e mesma interrogação: é preciso fornecer de si mesmo e do cuidado de si uma definição tal que dela se possa derivar o saber necessário para governar os outros."307 A resposta á primeira dessas perguntas implica, englobando-a, essa injunção que é tida como sendo o imperativo que melhor caracterizaria a civilização ocidental: o "conhece-te a ti mesmo". "O que é este elemento idêntico, de certa forma presente de parte a parte no cuidado: sujeito do cuidado, objeto do cuidado?", pergunta Foucault, acompanhando a Sócrates, ao que responde: "ela (a resposta) é conhecida, foi cem vezes dada nos diálogos de Platão: 'psykhês epimeletéon' (é preciso ocupar-se com a própria alma)". ${ }^{308}$ Foucault, então, prossegue: o que é mais interessante e original nisso não é tanto essa resposta—pois, afinal, a alma está em toda a obra de Platão, de maneiras variadas e de difícil síntese-mas a forma como se chegou, no diálogo, a ela. Esse movimento em direção a essa resposta

"começa com um pequeno conjunto de questões que eu resumiria, se quisermos, do modo como passo a expor. Quando se diz-'Sócrates fala a Alcibíades'—o que isto quer dizer? A resposta é dada: quer dizer que Sócrates se serve da linguagem. Este simples exemplo é ao mesmo tempo muito significativo. A questão colocada é a questão do sujeito. 'Sócrates fala a Alcibíades', o que isto quer dizer, pergunta Sócrates, ou seja, qual é o sujeito que está suposto quando se evoca esta atividade da palavra que é a de Sócrates em relação a Alcibíades? Trata-se, conseqüentemente, de fazer passar, para uma ação falada, o fio de uma distinção que permitirá isolar, distinguir, o sujeito da ação e o conjunto de elementos (palavras, ruídos, etc.) que constituem esta própria ação e permitem efetua-la. Trata-se, em suma, se quisermos, de fazer aparecer o sujeito na sua irredutibilidade." 309

A alma é aquilo que se serve, que faz uso: precisamente aquilo que é referido pelo termo khrêsis e essa, mostra-nos Foucault, é uma definição que se diferencia das outras definições que, da alma, encontramos ao longo do restante da obra de Platão. Alma como sujeito de ações, aquilo que se distingue, nas ações, de todo o resto, de todo o "conjunto de elementos" que as "constituem" e que "permitem efetuá-las": esse é o modo como a alma se insere na injunção "cuida de ti mesmo": cuida de que tenhas

\footnotetext{
${ }^{307}$ FOUCAULT, Michel; A hermenêutica do sujeito; op. cit., p. 65.

${ }^{308}$ Idem, pp. 66-67.

${ }^{309}$ Idem, pp. 68-69.
} 
alma, de que sejas sujeito de ações. Eis então que Foucault diz, resumindo todo esse percurso:

"quando Platão (ou Sócrates) se serve da noção de khrêstai/khrêsis para chegar a demarcar o que é este heautón (e o que é por ele referido) na expressão 'ocupar-se consigo mesmo', quer designar, na realidade, não certa relação instrumental da alma com todo o resto ou com o corpo, mas, principalmente, a posição, de certo modo singular, transcendente, do sujeito, em relação ao que o rodeia, aos objetos de que dispõe, como também aos outros com os quais se relaciona, ao seu próprio corpo e, enfim, a ele mesmo. Pode-se dizer que, quando Platão se serviu da noção de khrêsis para buscar qual é o eu com que nos devemos ocupar, não foi, absolutamente, a alma-substância que ele descobriu, foi a alma-sujeito." ${ }^{310}$

O cuidado de si no Alcibíades é, portanto, um diferencial que pode ajudar a quem queira governar a cidade de Atenas. É, igualmente, um conjunto de práticas e conhecimentos restritos a uma classe social, a classe dirigente, a elite da cidade. E, por último, é algo que se deve fazer num determinado momento da vida, quando ainda se está numa idade não muito avançada, quando "se sai das mãos dos pedagogos e se está

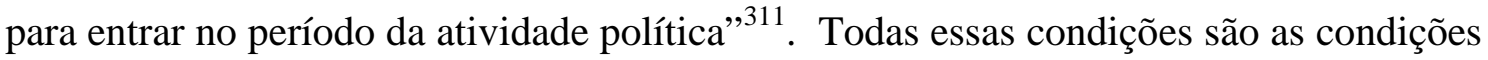
nas quais se encontra a personagem de Alcibíades e é fácil perceber como elas coincidem com os três princípios descritos no sub-capítulo sobre a khrêsis, de $O$ uso dos prazeres - as três estratégias do bom uso dos aphrodisia, já expostas-: o cuidado de si está ligado a uma finalidade, governar a cidade, da mesma forma que o uso bom dos prazeres vincula-os à natureza, à necessidade, promovendo uma discriminação dos prazeres, submetendo-os a uma espécie de peneira; ele também deve ocorrer numa determinada época da vida, atendendo a uma preocupação, a um saber, sobre o tempo correto das coisas, como ocorre com o bom uso dos prazeres; por último, não é todo mundo que deve praticar o cuidado de si-ainda que, nisso, haja uma certa contradição, pois Sócrates é, também, aquela figura que pára todo e qualquer um que encontre pela

\footnotetext{
${ }^{310}$ Idem, p. 71.

${ }^{311}$ Idem, p. 49.
} 
frente para inquirir se cuida ou não de $\mathrm{si}^{312}$-, sendo essa uma prática restrita à elite, da mesma forma que o uso temperante (ou não) dos prazeres é visto como relativo ao usuário e à sua condição social, ao seu status. A moral sexual dos antigos, ou melhor, a forma como esses refletiram o comportamento sexual enquanto domínio de experiência moral, portanto, insere-se dentro da preocupação, mais geral e ao mesmo tempo mais específica, do cuidado de si. Quando Foucault adentra o terceiro volume da História da sexualidade, ao qual dá o título de $O$ cuidado de si e que foca o período helenístico (séculos I e II da nossa era), essa noção, ou fórmula, já havia sido bastante exposta no volume II e o que restava por fazer era mostrar a longa evolução que ela veio a ter, transformando-se naquilo que ele chamou de uma "cultura do cuidado de si".

Essa evolução possui traços gerais que são mostrados ao longo dos dois primeiros capítulos de $O$ cuidado de $s i^{313}$ e na seqüência da leitura do Alcibíades, feita n'A hermenêutica do sujeito. Começar-se-á, gradualmente, depois de Platão, a caminhar rumo a um entendimento do cuidado de si que faz com que ele extrapole as condições sob as quais ele se dá no Alcibíades. Se nesse diálogo ficam claras as necessidades de que o cuidado de si ocorra com uma determinada finalidade (governar

\footnotetext{
${ }^{312}$ A descrição dessa forma de agir de Sócrates, aliás, é a forma como Foucault, a partir de A apologia de Sócrates, inicia esse curso de 1982 (cf. Idem, pp. 7-10); e é o próprio Foucault quem chama a atenção para a contradição (cf. Idem, p. 49).

${ }^{313}$ Em especial, remetemos ao fechamento do primeiro capítulo-em que Foucault faz uma descrição, à moda de outros livros seus (O Nascimento da Clínica, As palavras e as coisas, Vigiar e Punir), de um texto, de um documento que demonstra um pensamento veiculado em determinado momento da história, (no caso, A chave dos sonhos, de Artemidoro, do século II de nossa era)—onde ele enfatiza uma diferença: "Encontramos lá (no livro) facilmente os principais caracteres da experiência moral dos aphrodisia, tal como ela apareceu nos textos da época clássica. E o livro de Artemidoro, na medida em que ele não formula uma ética, mas em que utiliza para interpretar os sonhos uma maneira de perceber e de julgar os prazeres sexuais que lhe é contemporânea, atesta a durabilidade e a solidez dessa forma de experiência. (...) Se nos voltamos contudo na direção dos textos que têm por objetivo refletir sobre as práticas sexuais em si e de dar conselhos de conduta e preceitos de existência a respeito desse assunto, pode-se notar um certo número de modificações em relação às doutrinas de austeridade que eram formuladas na filosofia do século IV (A.C.) Rupturas, mudanças radicais, aparição de uma nova forma de experiência dos prazeres? Certamente não. E, no entanto, percebem-se inflexões: uma atenção mais viva, antes uma inquietude a respeito da conduta sexual, uma importância maior acordada ao casamento e às suas exigências, e menor valor emprestado ao amor dos rapazes: um estilo mais rigoroso, em suma. Estamos no terreno das evoluções lentas." (FOUCAULT, Michel; Histoire de la sexualité, vol. III-Le souci de soi; Paris, Gallimard, 2004, pp. 50-51)
} 
os outros), num determinado momento da vida (depois que se sai da "mão dos pedagogos") e somente para alguns poucos (os membros de uma aristocracia), no período helenístico vê-se um rompimento que conduz a que o cuidado de si seja entendido como um fim em si, a ser buscado em todas as fases da vida—em especial na velhice-e por todos. A esse respeito, sobre essas condições que se rompem, diz Foucault:

"quando digo que se rompem, não quero com isto significar, e o enfatizo de uma vez por todas, que se rompem naquele momento de uma vez por todas, que se rompem naquele momento como se algo de brutal e súbito tivesse ocorrido no período da instalação do Império, de modo que o cuidado de si, de repente e de vez, adotasse novas formas. $\mathrm{Na}$ realidade, é ao cabo de uma longa evolução, já perceptível no interior da obra de Platão, que estas diferentes condições do cuidado de si, expostas no Alcibíades, finalmente desapareceram. Esta evolução, já sensível em Platão, prossegue ao longo de toda a época helenística, tendo como elemento portador e, em grande parte sob o seu efeito, todas aquelas filosofias cínica, epicurista, estóica, que se apresentaram como arte de viver." ${ }^{314}$

Foucault não lamenta, em momento algum de sua obra, esse rompimento ${ }^{315}$.

importante parece ser mesmo entender quais os processos que conduziram a uma

\footnotetext{
${ }^{314}$ Idem, p. 102.

${ }^{315}$ Em diversas ocasiões, ele foi indagado a respeito da conveniência de uma "volta" à Antiguidade nos dias atuais. Uma das mais famosas e desconcertantes-principalmente para aqueles que não se dão conta de que Foucault quer, antes de tudo, chamar a atenção para a ruptura ocorrida na história, milenar, do cuidado de si-é aquela em que seus entrevistadores lhe perguntam sobre a estilização da relação a si, ao que ele responde que "a Antiguidade não cessou de colocar a questão de saber se é possível definir um estilo comum a esses diferentes domínios da conduta (a si, aos outros). Efetivamente, a descoberta desse estilo teria sem dúvida ensejado uma definição de sujeito. A unidade de uma 'moral de estilo' só começou a ser pensada no Império Romano, nos séculos II e III e, imediatamente, em termos de código e de verdade." Eles então afirmam: "um estilo de existência, isso é admirável. Esses gregos, você os tem achado admiráveis?"; e a resposta de Foucault, então é: "não". "Nem exemplares, nem admiráveis?" insistem; e ele: "não". "Como você os têm achado?", por fim, dizem; ele: "não muito interessantes. Eles se depararam muito cedo com aquilo que me parece ser o ponto de contradição da moral antiga: entre, por um lado, essa busca obstinada de um certo estilo de existência e, de outro, o esforço de torna-lo comum a todos, estilo que eles beiraram sem dúvida mais ou menos obscuramente com Sêneca e Epicteto, mas que não encontrou a possibilidade de crescer a não ser no interior de um estilo religioso. Toda a Antigüidade me parece ter sido um "profundo erro'." (FOUCAULT, Michel; "Le retour de la morale", in DE II, texto $n^{\circ} 354$, p. 1517) Nada de cultos, portanto, à Antigïdade, como também é demonstrado numa passagem de uma entrevista concedida em 1983 a Dreyfus e Rabinow quando, ao especular sobre até que ponto o nosso problema (moderno) não se parece com o problema dos clássicos antigos — fundar uma moral distinta e distante da religião e de um sistema legal "que intervenha na nossa vida moral, pessoal e íntima"-, seus interlocutores lhe perguntam: "você pensa que os gregos oferecem uma outra escolha, sedutora e plausível?"; e ele responde: "Não! Eu não procuro uma solução de recarga; não se acha a solução para um problema na solução de um outro problema levantado em uma outra época por pessoas diferentes. O que eu quero fazer não é uma história das soluções. Eu acho que o trabalho que cabe ser feito é um trabalho de problematização e de perpétua reproblematização. O que trava o pensamento é admitir implícita ou explicitamente uma forma de problematização, e procurar uma solução que possa vir
} 
transformação na noção de sujeito, nessa noção que, em Platão, como vimos acima, é aquilo que deve ser conhecida no ato de cuidar de si, a "alma-sujeito", que faz uso das coisas, que conduz. Que caminhos levaram a que essa noção adquirisse as cores da moderna noção, dessa noção que aproxima o sujeito de uma coisa, de uma substância, algo passível de ser "usado", manipulado, conduzido? Eis o que Foucault quis mostrar e que se encontra precisamente nessa ruptura ocorrida na noção de cuidado de si, uma ruptura que é a que permite, que abre caminho, para a noção cristã de sujeito, do sujeito renunciante, distante do seu desejo. Dir-se-ia que, ao narrar a história do cuidado de si, do seu destino dentro da civilização ocidental, Foucault realizou, no fundo, uma genealogia da governamentalidade.

A hermenêutica do sujeito expõe, detalhadamente, os ingredientes dessa transformação. Dentre esses, destaca-se o que diz respeito à idéia de salvação: na medida em que a injunção do cuidado de si se desliga, na vida do indivíduo, do momento de formação e passa a ser encarado como uma atividade que deve ser praticada ao longo da vida inteira, diz Foucault, ela adquire uma condição de "função crítica", que, por sua vez, faz com que esse cuidado passe a ter um "papel corretivo": "a prática de si não mais se impõe apenas sobre o fundo de ignorância, como no caso de Alcibíades, ignorância que ignora a si mesma. A prática de si impõe-se sobre o fundo de erros, de maus hábitos, de deformação e de dependência estabelecidas e incrustadas, e que se trata de abalar." "316 Cuidar se si passa a estar cada vez mais perto de "salvarse", cada vez mais perto de, como na medicina no seu combate contra as doenças, evitar

a substituir aquela que se aceita. Ora, se o trabalho do pensamento tem algum sentido-diferente daquele que consiste em reformar as instituições e os códigos-, é o de retomar pela raiz a maneira como os homens problematizam o seu comportamento (sua atividade sexual, sua prática punitiva, sua atitude em relação à loucura, etc.)." (FOUCAULT, Michel; “À propôs de la généalogie de l'éthique: un aperçu du travail en cours", in DE II, texto n 344, pp. 1430-1431.) "Não há Idade de Ouro", diz ele um pouco mais adiante; e isso não implica num pessimismo "anti-reformista", mas num "otimismo' do pensamento". (Idem, p. 1431).

${ }^{316}$ FOUCAULT, Michel; A hermenêutica do sujeito; op. cit., pp. 115-116. 
ser tomado pelos elementos malignos que estão sempre à espreita. Foucault, nesse sentido, não somente cita o estóico Musonius Rufus-“é cuidando-se sem parar (aeì therapeúntes) que se pode salvar-se"317 — mas relata como um outro, Sêneca, dispensa a idéia de que tudo na vida tenha o seu momento, a sua época, e introduz a de que haja uma "espécie de unidade" no que lhe diz respeito, uma unidade perante a qual é recomendável que se ouça a seguinte mensagem:

"fazei como se fôsseis perseguido, vivei apressado, senti que durante toda a vossa vida há pessoas atrás de vós, inimigos que vos perseguem. Estes inimigos são os contratempos da vida. São principalmente as paixões e os distúrbios que estes acidentes podem provocar em vós, quer quando jovem, quer na idade adulta, porquanto esperais ainda alguma coisa, sejais apegado ao prazer, cobiçais o poder ou o dinheiro. São todos estes os inimigos que vos perseguem. Pois bem, diante destes inimigos que vos perseguem, deveis fugir, e fugir o mais rápido possível. Apressai-vos em direção ao lugar que vos oferecerá um abrigo seguro. E o lugar que vos oferecerá um abrigo seguro é a velhice"318

Mas a ligação entre o cuidado de si e a idéia de salvação decorre também da generalização do primeiro, da noção que passa a viger nas escolas do período helenístico de que, ainda que essas práticas ligadas ao cuidado de si sejam práticas que se aprendem no âmbito desses grupos, qualquer um, independente do seu status, pode ter acesso a elas. Essa noção, diz Foucault, promoveu uma mudança importante, a do "eixo de partilha" do social: se no contexto cultural da Antigüidade a forma dessa

\footnotetext{
${ }^{317}$ Idem, p. 109. Essa mesma sentença é referida em $O$ cuidado de si (FOUCAULT, Michel; Histoire de la sexualité, vol. III...; op. cit., p. 64), livro onde o vínculo desse modo de exercício do cuidado de si com a medicina é exposto um pouco mais à frente: "toda uma série de metáforas médicas são utilizadas regularmente para designar as operações que são necessárias para os cuidados da alma: usar o escalpelo na ferida, abrir um abscesso, amputar, evacuar as superfluidades, passar medicações, prescrever poções amargas, calmantes ou tonificantes. A melhoria, o aperfeiçoamento da alma que se procura junto à filosofia, a paidéia que essa deve assegurar se tinge cada vez mais de colorações médicas. Formar-se e curar-se são atividades solidárias." (Idem, pp. 76-77)

${ }^{318}$ FOUCAULT, Michel; A hermenêutica...; op.cit., p. 136. Em $O$ cuidado de si faz referência a essa pressa ao comentar, no capítulo "A cultura de si", os autores desse período: "se formare, sibi vindicare, se facere, se ad studia revocare, sibi applicare, suum fieri, in se recedere, ad se recurrere, secum morari. Sêneca dispõe de todo um vocabulário para designar as formas diferentes que devem tomar o cuidado de si e a pressa com a qual se procura reencontrar-se consigo (ad se properare). Marco Aurélio, também, experimenta uma mesma pressa em se ocupar de si mesmo: nem a leitura nem a escrita devem retê-lo mais do cuidado direto que ele deve tomar do seu próprio ser: 'Não vagabundeies mais. Não estás mais destinado a reler tuas notas, nem as histórias antigas dos romanos e dos gregos, nem os extratos que reservavas para os teus dias anciãos. Apressa-te ao objetivo; diz adeus às vãs esperanças, acude se te lembras de ti mesmo (sautói oéthei ei ti soi melể sautou), tanto quanto isso seja ainda possível." (FOUCAULT, Michel; Histoire de la sexualité, vol. III...; op. cit., pp. 64-65).
} 
partilha, "tão importante e decisiva", se dava entre "os primeiros e a massa, os melhores

e a multidão (entre oi prôtoi e oi polloí: os primeiros e, depois, os numerosos)", no

contexto helenístico

"reencontramos (...) a oposição entre alguns e os demais, mas a partilha não é mais hierárquica: é uma partilha operatória entre os que são capazes e os que não são capazes [de si]. Não é mais o status do indivíduo que define, de antemão e por nascimento, a diferença que o oporá à massa e aos outros. É a relação consigo, a modalidade e o tipo de relação consigo, a maneira como ele mesmo será efetivamente elaborado enquanto objeto de seus cuidados: é aí que se fará a partilha entre alguns poucos e os mais numerosos. O apelo deve ser lançado a todos porque somente alguns serão efetivamente capazes de ocupar-se consigo mesmos. Reconhecemos aí a grande forma da voz que a todos se dirige e poucos ouvem, a grande forma do apelo universal que só a poucos garante a salvação. Encontramos aquela forma cuja importância será tão grande em toda a nossa cultura. É preciso dizer que ela não foi inventada exatamente aí. De fato, porém, em todos estes grupos cultuais de que lhes falei, em alguns pelo menos, achava-se o princípio de que o apelo era lançado a todos mas pouco numerosos eram os verdadeiros bacantes." 319

O caminho, como vemos, para isso que está "no cerne da maioria dos problemas

teológicos, espirituais, sociais, políticos do cristianismo"320 estava pavimentado; com o

mesmo "piche" do "cuidado de si", mas dentro de uma nova "fórmula"321.

${ }^{319}$ FOUCAULT, Michel; A hermenêutica...; op. cit., pp. 147-148.
${ }^{320}$ Idem, p. 148 .
${ }^{321}$ O capítulo intitulado “A cultura de si” de $O$ cuidado de si, oferece diversos exemplos dessa mudança de sentido, de Sócrates até o advento do cristianismo, no cuidado de si. O primeiro deles diz respeito à relação com o corpo: "o corpo do qual o adulto deve se ocupar, quando ele cuida de si mesmo, não é mais o corpo jovem que se tratava de formar por meio da ginástica; é um corpo frágil, ameaçado, minado por pequenas misérias e que, por sua vez ameaça a alma, menos por suas exigências demasiado vigorosas do que pelas suas próprias fraquezas." (FOUCAULT, Michel; Histoire de la sexualité, vol. III..., op cit., p. 79); o segundo, aos procedimentos de provação, que já apresentam elementos de renúncia, mas que ainda têm por finalidade "se tornar capaz de superar o supérfluo, constituindo sobre si uma soberania que não depende em nada de sua presença ou ausência." (Idem, p. 82); o terceiro, ao exame de consciência, que ainda não incorpora elementos de culpa, mas que também não é um exercício, como em Sócrates, de buscar o saber por meio do reconhecimento da ignorância de um não-saber e sim uma triagem que incide sobre as representações, distinguindo aquelas que são boas daquelas que são descartáveis (Idem, p. 88); o quarto e último, àquilo que passou a receber o nome de "conversão a si”, uma "fórmula de alento platônico, mas (...) (que) recobre a maior parte do tempo significações sensivelmente diferentes" (Idem, p. 89) e que implica numa "ética da mestria" que, "no entanto, (...) não se contenta em invocar a forma agonística de uma vitória sobre as forças difíceis de domar e de uma dominação capaz de se exercer sobre elas sem contestação possível", mas a de uma relação de possessão, decorrente de um "modelo jurídico" que se preocupa em estabelecer até que ponto cada sujeito está ou não "em si”, pertence "a si", está "em domínio de si" e que, a partir daí permite que se conceba uma espécie de prazer, ou de gozo consigo, desapegado de todo e qualquer elemento externo, de todo acaso, de todo lance da fortuna: "aquele que adveio a finalmente ter acesso a si mesmo é, para si, um objeto de prazer. Não somente se contenta daquilo que se é e se aceita de àquilo se ater, mas se 'regozija' consigo mesmo. Esse prazer para o qual Sêneca em geral emprega os termos gaudium ou laetitia é um estado que não é acompanhado nem seguido por nenhuma forma de perturbação no corpo e na alma; ele é definido pelo fato de não ser 
Mas, como é que os temas da salvação e do cuidado de si visto como salvação se relacionam com o tema do sujeito, esse tema que é o que interessa, no fundo, a Foucault—e que pode nos remeter à discussão a respeito da crítica, da atitude crítica, do pensamento e da liberdade? A questão é simples e passa pela idéia, correlata às rupturas ocorridas na noção clássica do cuidado de si, de que haja um único e exclusivo lugar para o sujeito dentro de uma ordenação que passa a ser vista como "natural". Na segunda hora da primeira aula de A hermenêutica do sujeito Foucault, ao descrever a diferença nas condições sob as quais o sujeito se relaciona com o conhecimentoDescartes sendo apontado como um "momento" no qual houve, de vez, uma ruptura, instauradora da percepção moderna sobre o assunto, entre o que o sujeito conhece e a transformação que esse conhecimento pode provocar no próprio sujeito-já havia mencionado a idéia de Deus, enquanto algo próximo a um "ponto de vista":

\begin{abstract}
"(na época de Descartes) havia muito tempo já se iniciara o trabalho para desconectar o princípio de um acesso à verdade unicamente nos termos do sujeito cognoscente e, por outro lado, a necessidade espiritual de um trabalho do sujeito sobre si mesmo, transformando-se e esperando da verdade sua iluminação e sua transfiguração. Havia muito tempo que a dissociação começara a fazer-se e que um certo marco fora cravado entre estes dois elementos. E este marco, bem entendido, deve ser buscado...do lado da ciência? De modo algum. Deve-se busca-lo do lado da teologia. A teologia (esta teologia que, justamente, pode fundar-se em Aristóteles (...) e que, com Santo Tomás, a escolástica, etc., ocupará, na reflexão ocidental, o lugar que conhecemos), ao adotar como reflexão racional fundante, a partir do cristianismo, é claro, uma fé cuja vocação é universal, fundava, ao mesmo tempo, o princípio de um sujeito cognoscente em geral, sujeito cognoscente que encontrava em Deus, a um só tempo, seu modelo, seu ponto de realização absoluto, seu mais alto grau de perfeição e, simultaneamente, seu Criador, assim como, por conseqüência, seu modelo. A correspondência entre um Deus que tudo conhece e sujeitos capazes de conhecer, sob o amparo da fé é claro, constitui sem dúvida um dos principais elementos que fazem [fizeram] com que o pensamento-ou as principais formas de reflexão-ocidental e, em particular, o pensamento filosófico se tenham desprendido, liberado, separado das condições de espiritualidade que os haviam acompanhado até então, e cuja formulação mais geral era o princípio da epiméleia heautoû.",322
\end{abstract}

provocado por nada que seja independente de nós mesmos e que escape, conseqüentemente, ao nosso poder; ele nasce de nós mesmos e em nós mesmos." (Idem, pp. 91-92)

${ }^{322}$ FOUCAULT, Michel; A hermenêutica do sujeito; op. cit., p. 36. 
Mas é bem mais à frente, nesse curso-e, note-se, quando ainda está tratando do período helenístico, anterior à época propriamente cristã-que a noção aparece novamente, para explicar as transformações na própria noção de sujeito, do si, implicado na injunção referente ao cuidado de si. A fuga rumo à velhice e o esforço para ser, em meio aos outros todos, "capaz de si", presentes no estoicismo, cinismo, epicurismo e, em grande parte, pitagorismo, esse movimento conjunto de forças direcionado à salvação, implica em um sujeito capaz de aceder a um ponto de vista único, universalizante, em sintonia com uma "natureza". Diz, a esse respeito, Foucault:

“(em Sêneca) se 'conhecer-se a si mesmo' está ligado ao conhecimento da natureza, se nesta busca de si, conhecer a natureza e [se] conhecer a si mesmo estão ligados um ao outro, é na medida em que o conhecimento da natureza nos revelará que somos nada mais que um ponto, um ponto cuja interioridade (como no cristianismo) não se põe evidentemente como um problema. O único problema que se lhe põe consiste precisamente em situar-se lá onde ele está ao mesmo tempo aceitar o sistema de racionalidade que o inseriu neste ponto do mundo." ${ }^{323}$

Esse conhecimento teria um efeito (pretensamente) "liberatório", na medida em que, por

meio dele, podemos ter

“continuamente sobre nós mesmos uma certa visão (...) na qual o objeto (...) seremos nós mesmos no interior do mundo, nós mesmos enquanto ligados, em nossa existência, a um conjunto de determinações e de necessidades cuja racionalidade compreendemos. Vemos (continua Foucault) conseqüentemente, que 'não se perder de vista' e 'percorrer com o olhar o conjunto do mundo' são duas atividades absolutamente indissociáveis uma da outra, sob a condição de ter havido esse movimento de recuo, esse movimento espiritual do sujeito, estabelecendo dele a ele mesmo o máximo de distância e fazendo com que, no topo do mundo, o sujeito chegue a se tornar consortium Dei: mais próximo de Deus, participante da atividade da racionalidade divina." ${ }^{324}$

Estamos muito longe, por conseguinte, daquela noção de sujeito enquanto aquele que faz uso, que se serve, que é a "posição singular, transcendente" a partir da qual toda ação ocorre, tal como expressa no Alcibíades; e Foucault o faz notar, particularmente no quesito relativo à prerrogativa do ato da escolha:

“...o que está aqui evocado (...) não é a possibilidade, para o indivíduo que a mereceu, de escolher entre os diferentes tipos de vida que lhe são propostos. Trata-se ao contrário de

${ }^{323}$ Idem, p. 340.
${ }^{324}$ Idem, p. 341. 
lhe dizer que não tem escolha e que, com esta visão do alto sobre o mundo, deve compreender que todos os esplendores que possa encontrar no céu, nos astros, nos meteoros, e a beleza da terra, as planícies, o mar, as montanhas, tudo isso está indissociavelmente ligado aos mil flagelos do corpo e da alma, às guerras, às pilhagens, à morte, aos sofrimentos. Mostramos-lhe o mundo não para que possa escolher, como as almas de Platão podiam escolher o seu destino. Mostramos-lhe o mundo precisamente para que compreenda que não tem escolha, e que nada se pode escolher se não se escolhe o resto, que há somente um mundo, um único mundo possível, e que é a ele que se está ligado. O único ponto de escolha é o seguinte: 'Delibera contigo mesmo e pesa bem o que queres. Uma vez tendo entrado nesta vida de maravilhas, é por ela que deverás sair.' A única escolha não é: que vida tu vais escolher, que caráter tu vais atribuir-te, queres tu ser bom ou mau? O único elemento de escolha que é dado à alma no momento em que, no limiar da vida, nascerá neste mundo é: delibera se queres entrar ou sair, ou seja, se queres ou não viver.",325

Também, é muito fácil ver que estamos igualmente distantes da atitude crítica de que

Foucault começou a falar em 1978, como um antídoto à governamentalidade e como

morada da liberdade. Para tal, basta que lembremos de duas de suas declarações: a de

que

"se a governamentalização é deveras o movimento pelo qual se tratava na realidade mesma de assujeitar os indivíduos por meio de mecanismos de poder que se arrogam uma verdade, pois bem! eu diria que a crítica é o movimento por meio do qual o sujeito se dá o direito de interrogar a verdade sobre seus efeitos de poder e o poder sobre seus discursos de verdade" ${ }^{, 326}$

e a de que "é afrontando a extrema e singular vontade de Deus que se é livre." 327

${ }^{325}$ Idem, pp. 346-347.

${ }^{326} \mathrm{Cf}$. infra, nota $\mathrm{n}^{\circ} 265$.

${ }^{327}$ Cf. infra, nota n 217 . 


\section{Parte III: Percussões}

A aproximação com Kant e com Platão, com esses dois imensos pensadores que praticamente moldaram aquilo a que o Ocidente dá o nome de filosofia, deve ter proporcionado a Foucault algo muito provavelmente novo na sua trajetória pessoal: uma sensação de pertencer a um grupo que compartilha dos mesmos horizontes, que fala uma mesma língua, que se apóia num solo comum, uma comunidade de interesses mútuos $^{328}$. Alguns poderão até mesmo dizer que Foucault acabou "fazendo as pazes" com a filosofia ao estabelecer o diálogo com esses dois pensadores, mas isso só se confirma no momento em que o que se entende como filosoficamente importante na

\footnotetext{
${ }^{328}$ São diversos os momentos, ao longo da leitura dos Dits et écrits, em que Foucault declara que não é, não pode e não deve ser classificado, como muitos tendem a fazer, como um estruturalista (cf. em especial os textos $\mathrm{n}^{\circ} 105$, p. 1164 de $D E I, \mathrm{n}^{\circ} 281$, pp. 871-872 e 881-891 e n 330 , pp. 1250-1254 de $D E$ II, bem como o comentário, quase ao final de A ordem do discurso, em que diz-sobre o que tinha acabado de expor a respeito do seu método-: "e agora, os que têm lacunas de vocabulário que digamse isso lhes soar melhor-que isto é estruturalismo" (FOUCAULT, Michel; A ordem do discurso, op. cit., p. 70)), ainda que em um deles em particular, datado de 1978, admita que "existe um ponto em comum entre todos esses que, nos últimos quinze anos, têm sido chamados de 'estruturalistas' e que, entretanto, à exceção de Lévi-Strauss, não o eram, isto é: Althusser, Lacan e eu. Qual era, em efeito, esse ponto de convergência? Uma certa urgência em recolocar em outros termos a questão do sujeito, de libertar-se do postulado fundamental que a filosofia francesa nunca abandou, desde Descartes, reforçado pela fenomenologia. Falando da psicanálise, Lacan tornou evidente o fato de que a teoria do inconsciente não é compatível com uma teoria do sujeito (no sentido cartesiano, mas também fenomenológico do termo). Sartre e Politzer tinham recusado a psicanálise criticando justamente a teoria do inconsciente, julgando-a incompatível com a filosofia do sujeito. Lacan concluiu, por sua vez, que era necessário abandonar a filosofia do sujeito e partir de uma análise dos mecanismos do inconsciente." (FOUCAULT, Michel; "Entretien avec Michel Foucault", in DE II, texto no 281, p. 871) Ao mesmo tempo, na relação que teve com um mestre seu, Georges Dumézil-a quem menciona, na sua aula inaugural no Collège de France, dizendo que lhe "deve muito" tanto no plano pessoal quanto intelectual - , verifica-se que, com todo o reconhecimento mútuo e até mesmo amizade que a caracterizava, ainda assim esse último julgava que o "discípulo" lhe "escapava" (cf. ERIBON, Didier; Michel Foucault e seus contemporâneos, Rio de Janeiro, Jorge Zahar, 1996, p. 81). No fundo, até o reconhecimento de Kant e Platão, eram somente Nietzsche, Bataille, Artaud, Klossowski, Roussel e Blanchot, esses anti-filósofos, o alvo da devoção foucaultiana—ou, ao menos da sensação de co-participação em algo comum, sendo eles aqueles que lhe permitiram, como diz a Trombadori, "desprender-se" da sua "formação universitária": "o que mais me impactou e fascinou neles (nessa ocasião só não menciona a Artaud e Roussel), e que lhes proporcionou essa importância capital para mim, é que o seu problema não era o da construção de um sistema, mas de uma experiência pessoal. Na universidade, pelo contrário, eu tinha sido treinado, formado, conduzido à aprendizagem de grandes maquinarias filosóficas que se chamavam hegelianismo, fenomenologia..." (Idem, pp. 861-862).
} 
obra desses dois passa pela percepção de uma subjetividade que se define a partir de uma relação com um "dizer verdadeiro" que lhe é atual e com o qual ela mantém uma sagitalidade $^{329}$. O projeto de uma ontologia do presente, ou de uma ontologia de nós mesmos, formulado no final do artigo What is Aufklärung-artigo esse que alguns comentadores consideram como o seu testamento intelectual ${ }^{330}$ - , quando ele terminava de expor os elementos, pinçados em Kant e em Baudelaire, de uma "atitude" ao mesmo tempo "moderna" e "crítica", esse projeto é o mesmo projeto, como tentei mostrar no último capítulo, contido na injunção "cuida de ti mesmo" subscrita por Platão; mas também é um projeto que se conecta com uma série de outros percursos do pensamento, ocorridos contemporaneamente, ou seja, ao longo dos séculos XX e começo do XXI, percursos esses a respeito dos quais Foucault porventura teve conhecimento, mencionando-os aqui e acolá, mas não chegando a dialogar diretamente com eles, como se não tivesse tido tempo para tal.

Este capítulo consiste numa abordagem aproximativa a alguns desses percursos intelectuais que, não estranhamente, se situam nos terrenos discursivos que Foucault, na parte final de As palavras e as coisas, isenta dos condicionantes que ele, nessa ocasião, demonstra cercarem as ciências humanas, destinando-as a um futuro tão infértil e de dias contados quanto o dos saberes que configuraram, em séculos anteriores, distribuições discursivas, disposições-epistémês-já extintas e, ao mesmo tempo,

329 "Eu me pergunto se não se poderia caracterizar um dos grandes papéis do pensamento filosófico, a partir justamente da questão kantiana 'Was ist Aufklärung', dizendo-se que a tarefa da filosofia é a de dizer aquilo que é "nós, hoje", diz Foucault numa entrevista de 1983 (FOUCAULT, Michel; "Structuralisme et poststructuralisme", in DE II, texto $\mathrm{n}^{\circ} 330$, p. 1267.)

${ }^{330}$ Um desses é Mariapaola Fimiani, para quem "os escritos de Foucault sobre a questão kantiana do Esclarecimento conservam uma caráter testamentário e sinóptico, eles adquirem a função de um índice retrospectivo e perspectivo para todo o percurso de sua pesquisa." (FIMIANI, Mariapaola; Foucault et Kant-critique, clinique, éthique; Paris, L'Harmattan, 1998, p. 15.) Esse artigo é o que ele publicou em 1984 na coletânea The Foucault reader, organizada por Paul Rabinow e que consta dos Dits et écrits com o número 339, tendo sido traduzido, para o francês, com o mesmo título, "Qu'est-ce que les lumières?", que o texto de número 351, uma aula que ele deu no Collège de France em 1983, publicada em 1984; por isso, aqui optamos por usar o título original, em inglês. 
parecidas com aquela, moderna, na qual essas (as ciências humanas) se situam e que tem a figura, nova, do homem, "no que ele tem de empírico", como o seu eixo principal $^{331}$. Esses percursos são percursos que se situam nos terrenos da psicanálise e da etnologia. Não estranhamente também, são percursos que, como veremos, se fazem girar em torno da temática do sujeito, da ética e da liberdade, a mesma temática que se vê aparecer no pensamento de Foucault a partir da emergência de conceito de governamentalidade, em 1978, e que, conforme mostro nos capítulos precedentes, chegou para ficar. O intuito dessa sondagem "percussiva" não é, de modo algum, uma forma de me dirigir rumo ao final deste trabalho apontando eventuais "saídas" aos "dilemas" postos pela trajetória percorrida pelo pensamento foucaultiano-essas saídas, se é que se trata de encontrá-las, posto que a proposta de Foucault é mais a de um "trabalho sobre os nossos limites", de uma incansável e paciente labuta problematizadora que "dá forma à impaciência da liberdade"332, essas "saídas" me parece que já se encontram na própria seqüência do trabalho desse pensador, efetivada nos cursos de 1983 e 1984, cujas degravações ainda estão por serem publicadas-mas o de demonstrar como é possível ir, com um olhar calcado nessa forma de exercício filosófico particular, à busca de outras experiências do pensamento que se desenvolveram em paralelo e que podem vir a enriquecer a experiência filosófica foucaultiana e a se alimentar dela.

\footnotetext{
${ }^{331}$ Foucault, nesse livro, caracteriza esses terrenos discursivos, "em relação às ciências humanas", como “contraciências (...) o que não quer dizer que sejam menos 'racionais', ou 'objetivas' que as outras-que ele, inclusive, já havia, momentos antes, caracterizado como 'saberes' e não ciências (cf. FOUCAULT, Michel; As palavras e as coisas, op. cit. p. 507)—, mas que elas as assumem no contrafluxo, reconduzemnas a seu suporte epistemológico e não cessam de 'desfazer' esse homem que, nas ciências humanas, faz e refaz sua positividade." (Idem, pp. 525-526). Muito do que Foucault coloca nessa última parte desse livro de 1966, como será visto, servirá de balizamento para o que se segue.

${ }^{332}$ Cf. infra, nota ${ }^{\circ} 274$.
} 
Cabe, contudo, especificá-los, pois não são qualquer psicanálise ou qualquer etnografia: esses percursos são, por um lado, o conhecimento que emerge da clínica lacaniana-mais especificamente, da segunda clínica lacaniana ${ }^{333}$-e, por outro, as descobertas da etnologia brasileira relativas ao pensamento ameríndio que têm procurado mostrar a sua natureza "perspectivista". Veremos, no que diz respeito a ambos, inicialmente, que são percursos que tematizam e que dão uma nova coloração a uma noção que, a princípio, não se apresenta em Foucault, o corpo ${ }^{334}$, mas que é perfeitamente passível de, dentro do seu pensamento, receber a tradução desse que ele afirmou ser o objeto por excelência das suas pesquisas-ou, pelo menos, um dos pólos desse, sendo o outro os dizeres verdadeiros-: o sujeito, a subjetividade ou a reflexividade de si sobre si. Veremos como, longe de ser um pressuposto, o que esses dois percursos entendem como sendo "corpo", é uma construção única, da qual não pode ser deixado de lado um ingrediente que nos aproxima de um universo político por excelência: a coragem; o mesmo ingrediente que eclode—seja na forma da sublevação, seja naquelas, mais "leves", do aude sapere esclarecedor e da "coragem da verdade"

\footnotetext{
${ }^{333}$ Encontra-se uma explicação desta no capítulo "A clínica lacaniana" do livro Você quer o que deseja? de autoria do psicanalista Jorge Forbes-cuja leitura é de vital importância para esta tentativa de aproximação entre Lacan e Foucault, até porque não possuo formação nenhuma em psicanálise e, como diz o próprio Foucault, para entender Lacan, não basta ler seus livros, mas também "ouvir o seu ensino público, participar de seus seminários e até mesmo, eventualmente, submeter-se a uma análise." (FOUCAULT, Michel; "Entretien avec Michel Foucault", in DE II, op. cit., p. 877) Diz Forbes, a respeito, que nessa clínica "há um novo ponto de ancoragem da clínica psicanalítica, apontado por Lacan em 1972-73, no Seminário 20: a "vontade de gozar"' e que, sobre esse gozo, que caracteriza um "ser" que se reconhece "dentro de si mesmo"—e não num Outro-, não se tem "nenhum controle". Assim, "as doenças da modernidade (anorexia, toxicomania, crimes hediondos, atos delinqüentes, doenças psicossomáticas) são doenças que chamei do curto-circuito do gozo , daqueles que vão direto ao prazer, sem intermediários. Elas são conseqüências do curto-circuito da palavra: curto-circuitam a palavra." (FORBES, Jorge, Você quer o que deseja?; Rio de Janeiro, Bestseller, 2003, pp. 170-171)

${ }^{334}$ Bem que se poderia argumentar que a disciplina, descrita em Vigiar e punir, tem o corpo como objeto, o que é verdade, mas aí esse não passa de um alvo, uma espécie de objeto auxiliar dentro de um quadro em que o que está sendo, de fato, objeto principal de descrição é o exercício da disciplina, o modo como esse exercício ocorre. Não é o caso, como nesses dois percursos que ora afirmamos serem congruentes ao de Foucault, de um momento de elaboração, de revisão ou de crítica de uma noção (de corpo), mas simplesmente da utilização dessa palavra no seu sentido mais corriqueiro, como um dos elementos de um enredo que, esse sim, é o foco do que se demonstra: a disciplina.
} 
socrática, que vai dar o nome aos dois últimos cursos dados por Foucault no Collège de France — da temática da liberdade tal qual a encontramos na obra de Foucault. 


\subsection{Capítulo 5: Sujeito, corpo e coragem}

\subsubsection{Em Lacan}

Retornemos ao ano de 1966: Foucault aplica o método arqueológico para traçar um controverso mapa das ciências humanas ${ }^{335}$, em As palavras e as coisas. Um conceito novo surge em meio à demonstração de como, ao longo dos últimos quinhentos anos, mudanças ocorreram, no Ocidente, nos saberes que dizem respeito àquilo que hoje concebemos como sendo a vida, o trabalho e a linguagem: o conceito de epistémê, que corresponde à disposição que rege o ordenamento dos discursos que têm pretensão de verdade, a forma como esses se distribuem e se relacionam entre si $^{336}$.

\footnotetext{
${ }^{335}$ É bom lembrarmos que estamos num momento em que o poder não é diretamente tematizado na obra desse pensador; uma época em que ele acreditava que a literatura, com a sua capacidade de pôr em questão o próprio "ser da linguagem", e a experiência da loucura, que permanentemente desafia ou, no mínimo, levanta suspeitas quanto à razão e seus excessos, eram o território, junto com a arqueologia que ele fundava, onde ele apostava as fichas de uma transformação que ele já almejava. Mas também é bom lembrar que o poder já era o que estava em questão, como ele diz, retrospectivamente, na entrevista a Trombadori: "não somente o poder de Estado, mas aquele que se exerce por meio de outras instituições ou formas de coação, uma espécie de opressão permanente na vida cotidiana. Aquilo que se suportava mal (em 1968), que era incessantemente questionado e que produzia esse tipo de mal-estar, e do que não tínhamos falado ao longo de doze anos, era o poder. E não somente o poder de Estado, mas aquele que se exercia no seio do corpo social, através de canais, de formas e de instituições extremamente diferentes. Não aceitávamos mais ser governados no sentido amplo de governo. Não falo em governo do Estado no sentido que o termo possui em direito público, mas desses homens que orientam nossa vida cotidiana por meio de ordens, de influências diretas ou indiretas como, por exemplo, as da mídia. Escrevendo a História da loucura, trabalhando sobre o Nascimento da clínica, eu acreditava fazer uma história genealógica do saber. Mas o verdadeiro fio condutor se encontrava no problema do poder." (FOUCAULT, Michel; "Entretien avec Michel Foucault", in DE II, texto n 281, p. 901)

${ }^{336}$ Não creio que este seja o lugar para uma discussão mais aprofundada desse conceito tão fundamental ao método arqueológico. O leitor que se interessar em tal aprofundamento tem, além de todo o corpo de As palavras e as coisas (cf., em especial, o capítulo 5, "Classificar") e de A arqueologia do saber, na obra
} 
Num primeiro momento, até o século XVI, essa disposição seguia o princípio da semelhança, fundava-se nela. Logo, séculos XVII e XVIII, os saberes passam a receber um outro princípio de distribuição: a representação, configurando uma epistémê clássica. Por último, num âmbito moderno, é o homem e a sua finitude que se erguem como fundamento e que permitem que positividades tais como a biologia, a economia e a filologia se dêem. O leitor, que já não entendia lá muito bem o que é que a abertura do livro, uma longa digressão a respeito das perspectivas que se fazem presentes no quadro Las meninas, do pintor espanhol Diego Velásquez, tem a ver com aquilo que se anuncia no subtítulo do livro—uma arqueologia da ciências humanas—, a essa altura já havia perdido, praticamente, as esperanças de ver qualquer menção à psicologia, à sociologia ou à literatura. Mas eis que elas aparecem no último capítulo, numa disposição, num lugar dentro da epistémê moderna, quase subalterno:

\begin{abstract}
"o que manifesta (...) o específico das ciências humanas, vê-se bem que não é esse objeto privilegiado e singularmente nebuloso que é o homem. Pela simples razão de que não é o homem que as constitui e lhes oferece um domínio específico; mas, sim, é a disposição geral da epistémê que lhes dá lugar, as requer e as instaura-permitindo-lhes assim constituir o homem como seu objeto. Dir-se-á, pois, que há 'ciência humana' não onde quer que o homem esteja em questão, mas onde quer que se analisem na dimensão própria do inconsciente, normas, regras, conjuntos significantes que desvelam à consciência as condições de suas formas e de seus conteúdos" ${ }^{337}$,
\end{abstract}

inicia ele, para, em seguida, dizer que

“as 'ciências do homem' fazem parte da epistémê moderna como a química ou a medicina
ou alguma outra ciência; ou, ainda, como a gramática e a história natural faziam parte da
epistémê clássica. Mas dizer que elas fazem parte do campo epistemológico significa
somente que elas nele enraízam sua positividade, que nele encontram sua condição de

de Roberto Machado, Ciência e saber-a trajetória da arqueologia de Michel Foucault, uma importante ferramenta. Nela, Machado arrisca uma definição: "O que caracteriza a reflexão de Foucault em Les mots et les choses é especificamente a investigação de uma ordem interna constitutiva do saber. É então que se coloca a questão da épistémè. Épistémè não é sinônimo de saber; significa a existência necessária de uma ordem, de um princípio de ordenação histórica dos saberes anterior à ordenação do discurso estabelecida pelos critérios de cientificidade e dela independente. A épistémè é a ordem específica do saber; é a configuração, a disposição que o saber assume em determinada época e que lhe confere uma positividade enquanto saber." (MACHADO, Roberto, Ciência e saber-a trajetória da arqueologia de Michel Foucault; Rio de Janeiro, Graal, 1982, p. 149).

${ }^{337}$ FOUCAULT, Michel; As palavras e as coisas, op. cit., pp. 504-505. 
existência, que não são, portanto, apenas ilusões, quimeras pseudocientíficas, motivadas ao nível das opiniões, dos interesses, das crenças, que elas não são aquilo que outros dão o estranho nome de 'ideologia'. O que não quer dizer, porém, que por isso sejam ciências" $" 338$

e finalizar assim:

“...elas desenham, quando se lhes faz a análise arqueológica, configurações perfeitamente positivas; mas, desde que se determinam essas configurações e a maneira como estão dispostas na epistémê moderna, compreende-se por que não podem ser ciências: o que as torna possíveis, com efeito, é uma certa situação de 'vizinhança' em relação à biologia, à economia, à filologia (ou à lingüística); elas só existem na medida em que se alojam ao lado destas-ou antes, debaixo delas, no seu espaço de projeção. Com elas mantêm, entretanto, uma relação que é radicalmente diferente daquela que se pode estabelecer entre duas ciências 'conexas' ou 'afins': essa relação, com efeito, supõe a transferência de modelos exteriores na dimensão do inconsciente e da consciência e o refluxo da reflexão crítica em direção ao próprio lugar donde vêm esses modelos. Inútil, pois, dizer que as 'ciências humanas' são falsas ciências; simplesmente não são ciências; a configuração que define sua positividade e as enraíza na epistémê moderna coloca-as, ao mesmo tempo, fora da situação de serem ciências; e se se perguntar então por que assumiram esse título, bastará lembrar que pertence à definição arqueológica de seu enraizamento o fato de que elas requerem e acolhem a transferência de modelos tomados de empréstimo a ciências. Não é pois a irredutibilidade do homem, aquilo que se designa como sua invencível transcendência, nem mesmo sua complexidade demasiado grande que o impede de tornar-se objeto de ciência. A cultura ocidental constituiu, sob o nome de homem, um ser que, por um mesmo e único jogo de razões, deve ser domínio positivo do saber e não pode ser objeto de ciência.",339

Pois bem, esse é o instante em que surgem, na obra, a psicanálise e a etnologia, que manteriam, em relação às ciências humanas, uma posição de "contraciências", formando "nos confins de todos os conhecimentos sobre os homens (...) um tesouro inesgotável de experiências e de conceitos, mas, sobretudo, um perpétuo princípio de inquietude, de questionamento, de crítica e de contestação daquilo que, por outro lado pôde parecer adquirido" "340: elas manteriam uma "posição privilegiada" na medida em que

"o que se espelha no espaço de seu discurso é muito mais o a priori histórico de todas as ciências humanas-as grandes cesuras, os sulcos, as partilhas que, na epistémê ocidental, desenharam o perfil do homem e o dispuseram para um saber possível. Era, portanto, muito necessário que ambas fossem ciências do inconsciente: não porque atingem no homem o que está por sob a sua consciência, mas porque se dirigem ao que, fora do

\footnotetext{
338 Idem, p. 505.

${ }^{339}$ Idem, p. 507.

${ }^{340}$ Idem, p. 517.
} 
homem, permite que se saiba, com um saber positivo, o que se dá ou escapa à sua consciência" 341

e terminariam por promover uma "dissolução" desse "homem que, nas ciências humanas, faz e refaz a sua positividade" ${ }^{342}$, contribuindo substantivamente para aquilo que conduz essa noção, fundadora da epistémê moderna, a um fỉm aventado, em palavras que ficaram na história do pensamento do século $\mathrm{XX}$, na última página desse livro $^{343}$.

É o que Foucault diz, nessa ocasião, especificamente em relação à psicanálise que serve de introdução ao primeiro desses percursos paralelos que creio serem capazes de "ressoar" harmônica e fecundamente quando postos lado-a-lado com o pensamento de Foucault sobre liberdade, subjetividade e ética—numa espécie de círculo ou de espiral que faz com que partamos de Foucault e terminemos nele-: a segunda clínica lacaniana. Diz Foucault:

"dando-se por tarefa fazer falar através da consciência o discurso do inconsciente, a psicanálise avança na direção desta região fundamental onde se travam as relações entre a representação e a finitude. Enquanto todas as ciências humanas só se dirigem ao inconsciente virando-lhe as costas, esperando que ele se desvele à medida que se faz, como que por recuos, a análise da consciência, já a psicanálise aponta diretamente para ele, de propósito deliberado-não em direção ao que deve explicitar-se pouco a pouco na

\footnotetext{
${ }^{341}$ Idem, pp. 524-525.

${ }^{342}$ Idem, pp. 525-526.

${ }^{343}$ Essa página que é também um sub-capítulo sem título e que diz assim: "Uma coisa em todo caso é certa: é que o homem não é o mais velho problema nem o mais constante que se tenha colocado ao saber humano. Tomando uma cronologia relativamente curta e um recorte geográfico restrito-a cultura européia desde o século XVI—-pode-se estar seguro de que o homem é aí uma invenção recente. Não foi em torno dele e de seus segredos que, por muito tempo, obscuramente, o saber rondou. De fato, de todas as mutações que afetaram o saber das coisas e de sua ordem, o saber das identidades, das diferenças, dos caracteres, das equivalências, das palavras_em suma, em meio a todos os episódios dessa profunda história do Mesmo - somente um, aquele que começou há um século e meio e que talvez esteja em via de se encerrar, deixou aparecer a figura do homem. E isso não constitui liberação de uma velha inquietude, passagem à consciência luminosa de uma preocupação milenar, acesso à objetividade do que, durante muito tempo, ficara preso em crenças ou em filosofias: foi o efeito de uma mudança nas disposições fundamentais do saber. O homem é uma invenção cuja recente data a arqueologia de nosso pensamento mostra facilmente. E talvez o fim próximo. (...) Se estas disposições viessem a desaparecer tal como apareceram, se, por algum acontecimento de que podemos quando muito pressentir a possibilidade, mas de que no momento não conhecemos ainda nem a forma nem a promessa, se desvanecessem, como aconteceu, na curva do século XVIII, com o solo do pensamento clássico-então se pode apostar que o homem se desvanceria, como, na orla do mar, um rosto de areia." (Idem, p. 536)
} 
iluminação progressiva do implícito, mas em direção ao que está aí e se furta, que existe com a solidez muda de uma coisa, de um texto fechado sobre si mesmo, ou de uma lacuna branca num texto visível e que assim se defende. Não há que supor que o empenho freudiano seja o componente de uma interpretação do sentido e de uma dinâmica da resistência ou da barreira; seguindo o mesmo caminho que as ciências humanas, mas com o olhar voltado em sentido contrário, a psicanálise se encaminha em direção ao momento-inacessível, por definição, a todo conhecimento teórico do homem, a toda apreensão contínua em termos de significação, de conflito ou de função-em que os conteúdos da consciência se articulam com, ou antes, ficam abertos para a finitude do homem. Isto quer dizer que, ao contrário das ciências humanas que, retrocedendo embora em direção ao inconsciente, permanecem sempre no espaço do representável, a psicanálise avança para transpor a representação, extravasa-la do lado da finitude e fazer assim surgir, lá onde se esperavam as funções portadoras de suas normas, os conflitos carregados de regras e as significações formando sistema, o fato nu de que pode haver sistema (portanto, significação), regra (portanto, oposição), norma (portanto, função). E, nessa região onde a representação fica em suspenso, à margem dela mesma, aberta, de certo modo ao fechamento da finitude, desenham-se as três figuras pelas quais a vida, com suas funções e suas normas, vem fundar-se na repetição muda da Morte, os conflitos e as regras, na abertura desnudada do Desejo, as significações e os sistemas, numa linguagem que é ao mesmo tempo Lei. Sabe-se como psicólogos e filósofos denominaram tudo isso: mitologia freudiana. Era realmente necessário que este empenho de Freud assim lhes parecesse; para um saber que se aloja no representável, aquilo que margeia e define, em direção ao exterior, a possibilidade mesma da representação não pode ser senão mitologia."

O saber clínico, esse saber que, conforme aponta o próprio Foucault,

"não pode atravessar o campo inteiro da representação, tentar contornar suas fronteiras, apontar para o mais fundamental, na forma de uma ciência empírica construída a partir de observações cuidadosas; essa travessia só pode ser feita no interior de uma prática em que não é apenas o conhecimento que se tem do homem que está empenhado, mas o próprio homem-o homem com essa Morte que age no seu sofrimento, esse Desejo que perdeu seu objeto e essa linguagem pela qual, através da qual se articula silenciosamente sua Lei" 345

e que não se pode desligar de uma prática—“este estrangulamento da relação entre dois

indivíduos, em que um escuta a linguagem do outro, libertando assim seu desejo do

objeto que ele perdeu (fazendo-o entender que o perdeu) e libertando-o da vizinhança sempre repetida da morte (fazendo-o entender que um dia morrerá) ${ }^{, 346}$ —, esse saber e essa prática, na versão da segunda clínica lacaniana, é um saber e uma prática que se ergue contra toda ação, dentro do quadro dessa relação específica, analítica, que aposte na fórmula, bastante comum, de que é o conhecimento da (própria) psique o que irá tirar

\footnotetext{
${ }^{344}$ Idem, pp. 518-519, grifos meus.

${ }^{345}$ Idem, p. 521.

${ }^{346}$ Idem, ibid.
} 
o analisando da situação de sofrimento que é aquela que, de início, o conduziu a procurar uma análise. Eis o que fundamenta, como mostra o psicanalista lacaniano Jorge Forbes, o traço que talvez seja o que mais marca uma análise lacaniana, distinguindo-a de uma análise ortodoxa, "standard", a variabilidade do tempo da sessão ${ }^{347}$ : que a conclusão venha antes do entendimento, que ela o preceda-e não o contrário, como se é freqüentemente levado a $\operatorname{crer}^{348}$. Para tal, é necessário que o próprio analista pratique essa ordem "invertida", no âmbito da relação, interrompendo a sessão a qualquer instante e procurando alimentar assim, no analisando, a mesma capacidade $^{349}$, no âmbito de sua vida. O esforço a ser empreendido, ou o caminho que uma relação analítica deve percorrer, então, parece muito próximo desse empreendimento que Foucault vislumbrava em 1966-e no qual ele incluía a própria psicanálise—de "desfazer" toda construção que se justifique num mergulho no que é representável no "homem": isso, no âmbito de uma análise, nada resolve, mantendo o

\footnotetext{
${ }^{347}$ Uma sessão "standard" se dá sempre em 50 minutos, tal como estabelecido por uma tradição que surgiu na clínica de Freud, não como um requisito "técnico", mas como uma contingência. Na sessão lacaniana, tudo varia, de acordo com a percepção do analista a respeito do momento certo de interromper a sessão ou, até, mesmo, de retoma-la, repeti-la no mesmo dia ou num outro, também variável.

${ }^{348}$ Cf. a conferência "O tempo da sessão", in FORBES, Jorge; Você quer o que deseja?; op. cit., 2003, pp. 122-135. Nela, esse autor mostra que isso tem um nome, "conclusão precipitada", e conjectura: toda conclusão é precipitada, na medida em que se entende que "a base epistemológica da psicanálise é o conflito do homem com o mundo, e que esse conflito não se cura." Se é assim, então "a força está no termo precipitada. É precipitada em relação a quê? É precipitada em relação a uma suposta conclusão, justa, totalmente demonstrável. Concluo antes de chegar ao final. Ora, se eu concluo antes de chegar ao fim, não há por que aumentar o tempo de raciocínio de um analisando. Não se trata de dar mais tempo. Trata-se de fazer o oposto, de leva-lo à possibilidade de concluir sobre o conflito e não de esperar o conflito ser resolvido para depois concluir. Trata-se, numa análise, de buscar um modo de trabalhar que leve o analisando à precipitação ou à conclusão em ato." (Idem, pp. 123-124) Em outra de suas conferências, "A ação do silêncio", também fala sobre isso ao contestar que o silêncio do analisando deva ser respondido com a contratransferência, em que o "sentimento do analista" é utilizado para "preencher o texto da história do analisando": isso, que é algo que permite o prolongamento da sessão, pode deixar o analisando "no lodo do gozo narcísico e leva-lo a perder muito tempo de análise e de vida. Lacan propõe uma razão clínica do porquê da precipitação do tempo: forçar o cálculo lógico chama-se ato. A análise deve possibilitar à pessoa atingir esse ato.” (Idem, p. 121)

${ }^{349}$ Trata-se de fato de uma capacidade que o analista deve ter, como mostra a crônica de Forbes que relata o encontro entre um pai de uma analisanda e o analista da filha ("O valor do desejo", idem, pp. 21-24), em que o analista, após escutar e concordar com todas as razões que o pai expõe contrárias aos aumentos-justificáveis do ponto de vista do contexto analítico-do preço das sessões, ainda assim não cede: "um analista tem que suportar o mal-entendido, próprio à defasagem entre o desejo e a necessidade, cerne da psicanálise." (Idem, p. 23)
} 
analisando num "gozo" que é um mero "gozo do pensamento" 350 ; o mesmo ocorre no âmbito do saber, onde só o que se faz, com as ciências humanas, é uma atualização de relações de poder.

O Foucault de 1982, por sua vez, vê as coisas sob o ângulo daquilo que fez com que tenha sido engendrado, em um determinado momento da história do ocidente, um sujeito que é esse que, no presente, necessita da psicanálise, seja para se livrar dessa vestimenta de "homem" que as ciências humanas lhe impõem, seja para—o que não deixa de estar ligado a essa primeira condição—-se tornar um sujeito capaz de concluir, de agir e, assim, impor a marca da sua singularidade ao mundo, "gozar" no sentido lacaniano, em que "a palavra não vai buscar nada além dela (...) onde a palavra em si mesma é satisfação" ${ }^{351}$. O poder pastoral, esse poder que Foucault mostra ter emergido nos primeiros séculos da nossa era, com os pensadores do período helenístico, é a configuração precisa em que aparece esse sujeito que se concebe como "nada mais que um ponto" dentro de um universo que é ordenado e que cabe ser conhecido, para nele se encontrar a localização exata desse "ponto"352, ou, dito de outra forma, também nas palavras desse Foucault de 1982, em que aparece essa "alma-substância" que se sobrepôs, nessa época, à “alma-sujeito" que estava por trás (ou na frente, vinculada a ela, em todo caso) da noção grega de $k h r e ̂ s i s^{353}$, fundante, como vimos, do cuidado de si na sua acepção platônica. O cristianismo, desde o seu início, se pode dizer, tanto quanto

${ }^{350} \mathrm{O}$ exemplo que Forbes dá desse tipo de gozo é um que parte do seu contrário, de uma conclusão precipitada, uma ação portanto, com tudo o que há de risco e de aposta: quando da tentativa de golpe em 2002 na Venezuela, contra o presidente Hugo Chávez, o então presidente brasileiro, Fernando Henrique Cardoso, se manifestou logo contrário a ele (o golpe deflagrado), liderando um coro que logo o seguiu: "o que levou Fernando Henrique Cardoso a dizer isso? Ele poderia ter esperado para ver, que é o que normalmente as pessoas fazem: deixe-me ver para onde vai. Ele poderia entrar num cálculo: vale a pena apoiar, não vale a pena...O que o Brasil vai ganhar com isso, o que o Brasil não vai ganhar com isso... $\mathrm{O}$ petróleo vai subir, o petróleo vai baixar... Se eu sou favorável, fico mais perto de Bush, mais distante do Bush, mais isso e mais aquilo... Portanto, ele poderia estar no gozo do pensamento.” (Idem, p. 132)

${ }^{351}$ Idem, p. 121.

${ }^{352}$ Cf. infra, nota n 323 .

${ }^{353} \mathrm{Cf}$. infra, nota $\mathrm{n}^{\mathrm{o}} 310$. 
as ciências humanas (ou não), o saber sobre o Estado, sobre a sexualidade, sobre as instituições, nos tempos correntes, é um "discurso verdadeiro", que faz uso dessa mesma noção de sujeito cuja emergência Foucault se empenhou em descrever na década de '80 nos seus cursos e livros; um sujeito que não se concebe como usuário do mundo, que permite que a sua vida seja conduzida —em vez de procurar conduzi-la ele mesmo, como o sujeito que é buscado por Platão-, e que, por isso mesmo, na perspectiva lacaniana, vai (ou necessita ir) parar no divã. Trata-se, em outros termos, de um sujeito que não "cuida de si”, que não conhece ou não dá atenção ao seu desejo e à verdade nele presente, tão ocupado que está em obedecer ao que lhe é apresentado como verdade.

É possível aprofundar isso, repetindo que todo o esforço da segunda clínica lacaniana gira em torno de encontrar o que está para além do representável, para além do circuito da palavra, e que se situa no "corpo" e naquilo a que Lacan deu o nome de Real. O corpo em Lacan é uma construção, algo que se aproxima de um estilo, único e singular: é o resultado de uma análise. E o que o analista almeja é que o analisando seja capaz, ao final do processo, de se responsabilizar por esse "corpo", que é um corpo que decide, que age: o analisando deve ser capaz de arcar com as conseqüências de suas decisões e de seus atos, do seu desejo, enfim, de suporta-los. Isso implica em que ele encontre o ponto daquilo que recebe o nome de "honra", que é o ponto para além do qual a (sua) vida deixa de fazer sentido, caso transposto. O oposto à honra é o reger-se pelo princípio de "salvar a própria pele", uma forma de, no dizer de Forbes, "se livrar da subjetividade". Numa análise, esse ponto (a honra) é atingido quando o analisando experimenta a vergonha, pois "a honra é aquilo que recobre a vergonha": "há uma vergonha fundamental em cada um, que a honra vai recobrir, anterior ao olhar do Outro, 
que dá uma pista para a ancoragem da satisfação desbussolada, do gozo, para a existência de uma estrutura no Real", diz esse autor numa conferência que intitulou "A honra e o sentido da vida" ${ }^{354}$, exemplificando com a figura de um conhecido maître d'hôtel do século XVII, Vatel, que preferiu a morte diante da evidência de não ter sido capaz de cumprir a sua função de preparar a tempo o jantar que o rei ao qual servia oferecia a um convidado: "Vatel é um exemplo comezinho mas mostra que a aristocracia, no sentido analítico, do ponto singular de cada um, é democrática, acessível a qualquer um. Na psicanálise, o que diferencia o aristocrata do não-aristocrata não é o berço, é a coragem." 355 Ora, essa vida pautada pela honra e oposta ao "salvar a própria pele", não é, por acaso, um dos traços salientados por Foucault, em Sócrates, logo nas primeiras aulas de $A$ hermenêutica do sujeito, quando ainda se aproxima, analisando $A$ apologia de Sócrates, do tema do cuidado de si, que é exposto, em toda a sua maturidade, no Alcibíades? Se não, vejamos, nas palavras do próprio Foucault:

"uma primeira passagem (sobre o cuidado de si na Apologia) encontra-se em 29d da Apologia. Defendendo-se, fazendo aquela espécie de alegação fictícia diante de seus acusadores e de seus juízes, Sócrates responde, nesta passagem, à objeção que passo a descrever. É ele censurado por estar atualmente em uma situação tal que dela 'deveria ter vergonha'. A acusação, se quisermos, consiste em dizer: não sei muito bem o que tu fizeste de mal, mas confessa que, de todo modo, é vergonhoso ter levado uma vida tal que agora te encontres diante dos tribunais, que agora estejas sob o golpe de uma acusação, que agora corras o risco de seres condenado e, até mesmo talvez, condenado à morte. Para alguém que levou um certo modo de vida, que não se sabe bem qual foi, mas tal que se arrisca a ser assim condenado à morte após um julgamento como este, afinal, não há nisto alguma coisa de vergonhoso? Ao que Sócrates responde que, ao contrário, está muito orgulhoso de ter levado esta vida e que, se alguma vez lhe pedissem que levasse outra, recusaria. Diz ele: estou tão orgulhoso de ter levado a vida que levei que mesmo se me propusessem indulto não a mudaria. Eis a passagem, eis o que diz Sócrates: 'Atenienses, eu vos sou reconhecido e vos amo; mas obedecerei antes ao deus que a vós; enquanto tiver alento e puder fazê-lo, estejais seguros de que jamais deixarei de filosofar, de vos [exortar], de ministrar ensinamentos àqueles dentre vós que eu encontrar." 356

\footnotetext{
${ }^{354}$ Idem, pp. 75-90.

${ }^{355}$ Idem, p. 82.

${ }^{356}$ FOUCAULT, Michel; A hermenêutica do sujeito; op. cit. pp. 7-8.
} 
Sócrates poderia ter tido todas as honrarias que um homem da sua importância podia

chegar a ter em Atenas, mas não era aí que se estava a sua "honra", como mostra

Foucault ao citá-lo:

"'Que tratamento, que multa mereço eu por ter acreditado que deveria renunciar a uma
vida tranqüila, negligenciar o que a maioria dos homens estima, fortuna, interesse
privado, postos militares, sucesso na tribuna, magistraturas, coalizões, facções políticas?
Por ter me convencido que com meus escrúpulos eu me perderia se entrasse por esta via?
Por não ter querido me comprometer com o que não tem qualquer proveito nem para vós
nem para mim? Por ter preferido oferecer, a cada um de vós em particular, aquilo que
declaro ser o maior dos serviços, buscando persuadi-lo a preocupar-se (epimeletheíe)
menos com o que lhe pertence do que com sua própria pessoa, a fim de se tornar tão
excelente, tão sensato quanto possível, de pensar menos nas coisas da cidade do que na
própria cidade, em suma, de aplicar a tudo estes mesmos princípios? Que mereci eu,
pergunto, por me ter assim conduzido [e por vos ter incitado a vos ocupar com vós
mesmos? Nenhuma punição, certamente, nenhum castigo, mas (...)] um bom tratamento,
atenienses, se quisermos ser justos.",357

Sócrates foi um aristocrata da coragem—e não do saber, como o "eleito" estóico

ou cristão, aquele que se "salva" por meio do "conhecimento" 358 — e isso, a retomada da

palavra e do gesto socráticos, pode ser uma contribuição que Foucault venha a deixar

aos seguidores de $\operatorname{Lacan}^{359}$ : que talvez a prática que eles procuram já estivesse presente

\footnotetext{
${ }^{357}$ Idem, pp. 9-10 (grifo meu).

${ }^{358}$ Cf. infra, notas $n^{\mathbf{0}} 317$ a 319.

${ }^{359}$ São diversos os momentos em que Foucault se manifestou enquanto um curioso do percurso lacaniano. N'A hermenêutica do sujeito ele lhe reconhece, por exemplo, na segunda hora da primeira aula, ter sido "o único depois de Freud a querer recentralizar a questão da psicanálise precisamente nesta questão das relações entre sujeito e verdade" fazendo, com isso, "ressurgir, no interior mesmo da psicanálise, a mais velha interrogação, a mais velha inquietude desta epiméleia heautô̂, que constitui a forma mais geral da espiritualidade. Esta questão, que não me cabe resolver, é certamente a seguinte: é possível, nos próprios termos da psicanálise, isto é, dos efeitos de conhecimento portanto, colocar a questão das relações do sujeito com a verdade, que-do ponto de vista, pelo menos, da espiritualidade e da epiméleia heautô̂não pode, por definição, ser colocada nos próprios termos do conhecimento?" (FOUCAULT, Michel; $A$ hermenêutica do sujeito; op. cit., pp. 40-41) É algo bem próximo a isso o que ele diz numa curta entrevista concedida em 1981 e publicada no Corriere della sera, respondendo a uma pergunta relativa ao "hermetismo" e ao "terrorismo intelectual" de que Lacan era acusado: "Eu creio que o hermetismo de Lacan deve-se ao fato de que ele queria que a leitura de seus textos não fosse simplesmente uma 'tomada de consciência' de suas idéias. Ele queria que o leitor se descubra por si mesmo, como sujeito de desejo, por meio dessa leitura. Lacan queria que a obscuridade dos seus Escritos fosse a complexidade mesma do sujeito e que o trabalho necessário para compreendê-lo fosse um trabalho a ser realizado sobre si mesmo." (FOUCAULT, Michel; "Lacan, le 'liberateur' de la psychanalyse", in DE II, texto no 299, p. 1024.) Um outro momento o encontramos nas palavras do herdeiro de Lacan, Jacques-Alain Miller, no famoso colóquio Michel Foucault philosophe realizado em Paris em1988 em homenagem a Foucault, onde ele relata ainda vê-lo a lhe dizer, após um dia de trabalho em 1972 compulsando em conjunto os arquivos relativos a Charcot na Salpêtrière: "algum dia você terá que me explicar Lacan” (MILLER, Jacques-
} 
no cuidado de si platônico, que ela não seja um mero sinal dos tempos globalizados ${ }^{360}$.

Mas, inversamente, o percurso da psicanálise lacaniana pode nos ajudar a entender uma

parte importante desse texto que introduz a publicação dos volumes II e III da História

da sexualidade, intitulado "Modificações", e que são as primeiras palavras com as quais

Foucault se dirige ao grande público após um período de oito anos de "silêncio", um silêncio em que muitos enxergam os tons de uma intensa "crise" pessoal ${ }^{361}$ e que, como vimos acima, na verdade, diz respeito à mudança conceitual ocorrida ao longo do processo de gestação da noção de governamentalidade. Essa parte é aquela em que ele se justifica a respeito da mudança que fez no seu percurso inicialmente traçado e diz que "há momentos na vida em que a questão de saber se se pode pensar de outra forma e
enxergar de outra forma em relação ao que se pensa e se enxerga é indispensável para se
continuar a enxergar ou a pensar. Me dirão talvez que esses jogos consigo mesmo devem
se restringir às coxias; e que eles fazem parte, no máximo, desses trabalhos de preparação
que se auto-destroem na medida em que atingem os seus efeitos. Mas o que é a filosofia
hoje—u quero dizer a atividade filosófica-senão o trabalho crítico do pensamento
sobre si mesmo? E se não consiste em, no lugar de legitimar aquilo que já se sabe,
procurar saber como e até onde seria possível pensar de outra forma? Há sempre algo de
irrisório no discurso filosófico quando ele quer, do exterior, legislar sobre os outros,

Alain; "Michel Foucault et la psychanalyse", in Des Travaux/Seuil (eds.) Michel Foucault philosopherencontre international; Paris, Éditions du Seuil, 1989, p. 81.)

${ }^{360}$ Lacan, ao final de uma conferência proferida em 1967 na Faculdade de Medicina de Estrasburgo intitulada "Afinal, vocês terão escutado Lacan" demonstra bem um sentimento parecido, quando diz que a disciplina imposta ao psicanalista "é contrária à da autoridade científica. Não digo à do cientista. $\mathrm{O}$ cientista da ciência moderna tem com efeito uma relação singular com sua superfície social e com sua própria dignidade, que está bem longe da forma ideal situada no fundo que constitui seu estatuto. Todos sabem que o que especifica as formas mais atuais de pesquisa científica não é em hipótese alguma identificável ao tipo tradicional de autoridade científica, daquele que sabe e toca, que opera e cura apenas pela presença de sua autoridade" e que o analista à altura de, "redobrando os passos de Freud", fazer a psicanálise "avançar novamente", seria um que conquistasse a "justa situação de despojamento, de 'desmuniciamento' (...) que é a do analista enquanto um homem entre outros, que deve saber que não é nem saber, nem consciência, mas dependente tanto do desejo do Outro quanto de sua fala." (LACAN, Jacques; Meu ensino; Rio de Janeiro, Jorge Zahar, 2006, pp. 123-124)

${ }_{361}$ É o caso de John Rachjman, que, por sua vez, calca-se muito no depoimento pessoal de Gilles Deleuze, de quem Foucault se afastou a partir de 1977 (cf. RACHJMAN, John; Eros e verdade_Lacan, Foucault e a questão da ética; Rio de Janeiro, Jorge Zahar, 1994, pp. 11-22.) Chamam a atenção, na obra desse comentador, onde ele acertadamente, ao meu ver, tenta mostrar uma confluência do pensamento de Foucault com o de Lacan, dois fatos: 1) que ele diga que "parte do drama e da dificuldade da obra final de Foucault residiria em sua tentativa de se afastar da importância singular adquirida pela psicanálise na filosofia francesa contemporânea, basicamente através da obra de Lacan" (idem, p. 9)—o que não está absolutamente calcado em nenhum evidência conhecida ou citada por esse autor e que acaba, ao meu ver, por contradizer todo o esforço do livro-e 2) que ele tenha que recorrer a um termo alheio a ambos esses pensamentos-ao "eros do pensamento"—para poder estabelecer uma ligação entre eles. 
dizer-lhes aonde está a sua verdade e como encontrá-la, ou quando ele se empenha em lhes guiar dando uma de 'joão-sem-braço'; mas é seu direito explorar aquilo que, no seu próprio pensamento, pode ser modificado pelo exercício que ele promove de um saber que lhe é alheio." 362

Ora, aí está uma declaração cuja importância não deve ser menosprezada: nela, Foucault está falando de si mesmo, do momento pelo qual passou após a publicação de $A$ vontade de saber e da expectativa que então foi gerada em relação a si mesmo e ao seu trabalho. Uma expectativa que era sua e dos seus editores, da sociedade, do "mundo" enfim, na qual ele se encaixava como sendo aquele que iria dizer, enfim, uma verdade, a verdade do poder: nada mais alheio ao que ele tinha feito e vinha fazendo até então, desde o seu primeiro livro. Em suma, algo perigoso porque distante de si mesmo, mas algo do qual ele se deu conta a tempo e que lhe serviu para, finalmente, se encontrar, tal como um analisando que encontra o seu ponto de honra, a sua vergonha-e é mesmo com uma certa vergonha que ele enuncia, nessa introdução, que depois de tantas andanças, acabou "na vertical" de si mesmo ${ }^{363}$ —e para poder dizer em alto e bom som o que ele, de fato é-e sempre foi-: um historiador da verdade ${ }^{364}$.

Disso, ele já havia chegado perto em pelo menos uma ocasião, em 1973, na primeira conferência de $A$ verdade e as formas jurídicas, quando anuncia que há duas formas, uma interna e uma externa, de se fazer tal história, sendo que

\footnotetext{
${ }^{362}$ FOUCAULT, Michel; Histoire de la sexualité, vol. II...; op. cit., pp. 15-16.

${ }^{363}$ Idem, p. 19. "Eis a ironia desses esforços que se faz por mudar a própria forma de ver, por modificar o horizonte daquilo que se conhece e por procurar se distanciar um pouco. Conduziram eles efetivamente a pensar de outra forma? Talvez eles tenham no máximo permitido pensar de outra forma aquilo que se pensava e perceber o que se fez segundo um ângulo diferente e sob uma luz mais nítida. Acreditava-se se distanciar e encontra-se na vertical de si mesmo", é o que diz, mais precisamente.

${ }^{364}$ Essa caracterização não me parece ferir, em absoluto, a definição que ele dá de si mesmo como filósofo, já mencionada acima (cf. nota 36 do primeiro capítulo): aquele que se propõe a "refletir a respeito não do que é verdadeiro e do que é falso, mas da nossa relação com a verdade." Note-se que ele próprio, na seqüência dessa definição acrescenta que "é necessário completar; ela é uma maneira de se perguntar: se tal é a relação que nós temos com a verdade, como devemos então nos conduzir? Eu creio que aconteceu e que acontece sempre atualmente um trabalho considerável e múltiplo, que modifica ao mesmo tempo a nossa ligação com a verdade e nossa maneira de nos conduzirmos. E isso dentro de uma conjunção complexa entre toda uma série de pesquisas e todo um conjunto de movimentos sociais. É a própria vida da filosofia.” (FOUCAULT, Michel; "Le philosophe masque”, op. cit., p. 929).
} 
"a primeira é uma espécie de história interna da verdade que se corrige a partir de seus próprios princípios de regulação: é a história da verdade tal como se faz na ou a partir da história das ciências. Por outro lado, parece-me que existem, nas sociedades, ou pelo menos, em nossas sociedades, vários lugares onde a verdade se forma, onde um certo número de regras de jogo são definidas - regras de jogo a partir das quais vemos nascer certas formas de subjetividade, certos domínios de objetos, certos tipos de saber-e por conseguinte podemos, a partir daí, fazer uma história externa, exterior, da verdade" ${ }^{\text {"365 }}$

e que é precisamente o que, "utilizando eventualmente o modelo nietzscheano", vai fazer em tal ocasião ${ }^{366}$. Mas, tal como pode ocorrer em análises, lacanianas ou não, isso não recebeu, da parte de Foucault, então, a atenção devida, não era o momento para tal, a coisa não estava suficientemente elaborada; e eis que ele teve que fazer todo o percurso sobre o poder para finalmente poder chegar e dizer, em 1984, nessa mesma Introdução, que, estava optando por estudar a "lenta formação, durante a Antigüidade, de uma hermenêutica do si"- -em vez de dar prosseguimento ao projeto inicial relacionado ao poder e ao biopoder-, pois "afinal de contas, aquilo a que eu tenho me aferrado—aquilo a que eu tenho querido me aferrar há tempos—é uma iniciativa para pontuar alguns dos elementos que poderiam servir a uma história da verdade״ ${ }^{367}$ e que ele então consegue perceber melhor

"de que maneira, um pouco às cegas e por fragmentos sucessivos e diferentes, eu tenho estado tomado por essa empreitada de uma história da verdade: analisar não os comportamentos nem as idéias, não as sociedades e suas 'ideologias', mas as problematizações por meio das quais o ser se apresenta como podendo e devendo ser pensado e as práticas a partir das quais elas se formam.",368

Pode-se dizer que, com essas palavras e com o conteúdo do que escreve ao longo dos dois volumes que se seguem, Foucault demonstra ter chegado ao gozo lacaniano, em que, como diz Forbes, a palavra se "ajusta à vida", se "concilia com o corpo", tornandose a própria "pele"; é bem essa a idéia que ele próprio passa numa de suas últimas

\footnotetext{
${ }^{365}$ FOUCAULT, Michel; A verdade e as formas jurídicas; op. cit., p. 11.

${ }^{366} \mathrm{Cf}$. infra, nota ${ }^{\circ} 67$.

${ }^{367}$ FOUCAULT, Michel; Histoire de la sexualité, vol. II...; op. cit., p. 13.

${ }^{368}$ Idem, p. 19.
} 
entrevistas, concedida próxima ao lançamento desses dois volumes, quando diz que lhe parece que

\begin{abstract}
"n'A história da loucura, n'As palavras e as coisas e também em Vigiar e punir muitas coisas que se encontravam implícitas não podiam ser tornadas explicitas em função da maneira pela qual eu colocava os problemas. Eu procurei apontar três grandes tipos de problemas: o da verdade, o do poder e o da conduta individual. Esses três domínios da experiência só podem ser compreendidos uns em relação aos outros e não podem ser compreendidos uns sem os outros. O que me causou problemas nos livros precedentes foi ter considerado as duas primeiras experiências sem levar em conta a terceira. Fazendo aparecer essa última experiência, pareceu-me que ali havia uma espécie de encadeamento que não carecia, para se justificar, dos métodos ligeiramente retóricos pelos quais eu esquivava um dos três domínios fundamentais da experiência."369
\end{abstract}

Vê-se que o que Foucault encontrou no tema do cuidado de si e na literatura a seu respeito—-tema esse que ele não deixou de apontar como envolvendo uma ascesenão está longe da sua própria experiência de vida—por muitos apontada como uma "ascese"-, nesses anos que sucedem à publicação de $A$ vontade de saber. Tal como Sócrates, ele poderia ter seguido um caminho que certamente o cobriria de honrariastornando-se o teórico do (bio)poder-, mas o caminho que ele acabou escolhendo foi o mais difícil—o de explorar todo um terreno, da Antigüidade, que não lhe era, em absoluto, familiar-, porém aquele no qual, seguindo os seus "escrúpulos", ele não se perderia de si mesmo, daquilo que ele era e de que não abria mão.

\footnotetext{
${ }^{369}$ FOUCAULT, Michel; "Le retour de la morale", in $D E I I$, texto $\mathrm{n}^{\text {o }} 354$, p. 1516. Isso me leva, mais uma vez, a discordar da intepretação de Rachjman, para quem, "o que resta dos 'anos de crise' é uma massa bastatne volumosa de cursos, resenhas, entrevistas, palestras e artigos jornalísticos, concertnentes a uma ampla variedade de temas e questões, apresentados em várias ocasiões e ligados a diferentes grupos, dentro e fora do mundo acadêmico. É difícil apreendê-la como um todo. Sua busca de 'outros métodos retóricos' que não evitassem a questão do sujeito permaneceu inacabada, e a dificuldade de seu novo estilo, não resolvida." (RACHJMAN, John; Eros e verdade...; op. cit., p. 13)
} 


\subsubsection{No pensamento ameríndio}

A aproximação que a etnologia promove ou se propõe a promover em relação ao pensamento de outras culturas sempre irá ter como ressalva, ou como reticência, a acusação de que os conceitos que porventura venha a "descobrir" nos seus "nativos" são, na verdade, projeções, que ela se encarregaria de efetivar, da cultura ocidental sobre esse "outro", objeto da sua preocupação. Essa acusação não é uma exclusividade interna à etnologia—onde o perigo do "etnocentrismo" é sempre um fantasma à espreita, e a acusação de que tal ou qual colega a pratica, a mais grave das acusaçõespois ela costuma ser anteposta à etnologia como um todo por gente que se encontra fora dela, na sua vizinhança epistemológica, e que acredita que as ciências humanas já estão suficientemente munidas de questões—sobre as "sociedades", sobre o "homem"—cujas respostas haverão de se encontrar "interna corporis": tratar-se-ia, segundo esses, de um esforço inútil, já que nunca se deixará de pensar como ocidental. Ora, essa postura merece duas objeções da parte de uma filosofia, a primeira delas sendo a de que se é, de fato, verdade que nunca se deixará de pensar como se pensa, então é melhor fechar todos os cursos, não só de etnologia, mas os de filosofia, também! A segunda, remete ao fato de que essas acusações procedem de pessoas que, estando de fora do meio, não tem a menor idéia, parafraseando Foucault a respeito daqueles que o acusavam de 
"recusar a história" 370 , do "tipo de relação, ao mesmo tempo desapegada e respeitosa" que a grande maioria dos etnólogos mantêm com a alteridade, essa que dá sentido aos seus cotidianos e ao que fazem das suas vidas. Em outras palavras, não há ninguém mais preocupado em (não) ser etnocêntrico do que os próprios etnólogos.

Dito isso, reafirmada a crença de que a mera curiosidade seja o motor principal do que leva "nossos" etnólogos ao estudo do "outro", não há por que não se possa relatar a respeito de uma descoberta recente da etnologia brasileira relacionada ao pensamento dos povos que habitam a floresta amazônica e as suas chamadas "terras baixas", os povos ameríndios, e utilizar essa descoberta para aprofundar aspectos daquilo que tem sido explorado até agora no âmbito desta tese, ou seja, o pensamento de Foucault sobre a liberdade e sobre o sujeito.

Assim como ocorre com a trajetória lacaniana, a descoberta a que me refiro possui um histórico dentro do qual há um momento em que surge uma questão, relacionada ao "corpo", cuja "solução" irá determinar toda uma reorganização discursiva por parte daqueles que a promoveram. Não foi o caso de chamar o que se seguiu a ela de uma "segunda etnologia ameríndia", mas bem que se poderia pensar em algo próximo a isso ${ }^{371}$ : como com Lacan, o grupo de etnólogos do Museu Nacional do Rio de Janeiro que fez tal descoberta, liderados por Eduardo Viveiros de Castro, tinha atrás de si uma trajetória dentro da sua respectiva "disciplina", era (e é) "gente do ramo”, que percebia que algo não se encaixava entre a teoria e a realidade e que, então, resolveu mudar (a teoria, felizmente). No caso específico, o problema dizia respeito à teoria do parentesco: dentre as disponíveis na disciplina, não havia nenhuma que desse

\footnotetext{
${ }^{370} \mathrm{Cf}$. infra, nota $\mathrm{n}^{\circ} 61$.

${ }^{371}$ Veremos, mais à frente, como o nome que a ela se deu foi o de "perspectivismo e multinaturalismo ameríndios".
} 
conta das regras relativas a ele vigentes nas sociedades das terras baixas amazônicas. Em específico, o material etnográfico a respeito dos índios apinayé era o que apontava para esse desencaixe, partindo do trabalho pioneiro de Kurt Nimuendaju, datado de 1939, e da não existência do sororato $^{372}$ nessas sociedades, conforme relata o antropólogo Roberto da Matta, num artigo ${ }^{373}$ em que resume a sua tese a respeito dessa sociedade Timbira, Um mundo dividido: a estrutura social dos índios Apinayé, publicada em forma de livro em 1976. Esse desencaixe recebeu uma atenção da parte de diversos antropólogos e, inclusive, uma alcunha, a de "anomalia apinayé", até que o próprio da Matta levantou a suspeita de que a terminologia-que ele mesmo levantou in loco — utilizada nessa sociedade para estabelecer a sua estrutura—a que grupo um dado indivíduo pertence e como ele deve, a partir daí, se relacionar com os outros membros da sociedade, com quem pode casar, etc., ou, posto de outro modo e fugindo dos termos que o autor usou nessa ocasião, como se constrói a pessoa nessas sociedades-poderia ser melhor entendida caso se partisse daquilo a que ele deu o nome de "ideologia" e não o contrário, como sempre costumava acontecer nessas análises; ou seja, caso se empregasse o "sistema de idéias capaz de ser explicado e/ou discutido pelos próprios nativos" para entender a terminologia das relações sociais e não o contrário ${ }^{374}$.

Pois bem, o que esse autor levanta, quando da análise desse "sistema de idéias" apinayé, é que existem dois critérios, complementares entre si, que determinam os tipos

\footnotetext{
${ }^{372}$ Definido pelo Houaiss como: "sistema matrimonial no qual um homem substitui a esposa morta pela irmã mais nova desta."

373 DA MATTA, Roberto; "The Apinayé relationship system: terminology and Ideology", in MAYBURY-LEWIS, David (org.); Dialectical societies-the Gê and Bororo of Central Brazil; Cambridge, Harvard University Press, 1979.

${ }^{374}$ Idem, p. 86. É o que ele faz, ao longo do seu trabalho para, na sua conclusão, poder dizer que ele "mostrou que equações terminológicas que sobrepujam o contraste geracional podem ser produzidas por um sistema que não tem nada a ver com grupos de descendência unilineares, ou com qualquer princípio sociológico estrito que ordene toda a estrutura social apinayé, tal como poderia ser o caso se uma regra de descendência paralela fosse postulada." (Idem, p. 123)
} 
de relações existentes e que um desses é o da "substância comum”, que passa por laços que se estabelecem a partir de uma proximidade fisiológica ou biológica caracterizadas pela intimidade: são os laços que se estabelecem entre aqueles que dormem juntos, que comem juntos, que trocam, enfim, substâncias a tal ponto de, conforme dizem os apinayé, "cheirarem parecido". Para da Matta "entre os apinayé, esse idioma da substância (comum) é a melhor tradução para o termo 'parentesco' ou, melhor, ‘consangüinidade'., 375 Um passo importante estava sendo dado por da Matta, que, pouco tempo depois, assina um artigo, junto com Anthony Seeger e Eduardo Viveiros de Castro, em que, partindo da constatação de que muitas etnografias recentes de povos ameríndios “têm-se detido sobre 'ideologias nativas' a respeito da corporalidade: teorias de concepção, teoria de doenças, papel dos fluidos corporais no simbolismo geral da sociedade, proibições alimentares, ornamentação corporal", afirmam que essas etnografias

"necessitam recorrer a estas ideologias da corporalidade para dar conta dos princípios da estrutura social dos grupos; tudo se passa como se os conceitos que a Antropologia importa de outras sociedades-linhagem, aliança, grupos corporados—não fossem suficientes para explicar a organização das sociedades brasileiras" ${ }^{\text {376, }}$,

posto que, como dizem um pouco mais à frente, "as sociedades do continente (sulamericano) se estruturam em termos de idiomas simbólicos que—esta é a diferença com os símbolos africanos, europeus, etc.—não dizem respeito à definição de grupos e à transmissão de bens, mas à construção de pessoas e à fabricação de corpos."377

\footnotetext{
375 Idem, p 89. O outro critério, o da cerimonialidade diz respeito a grupos que se constituem exclusivamente em contextos rituais e públicos, onde a "participação de todos os membros da sociedade é um prerequisito", marcando relações que não "operam no dia-a-dia, seja como grupos de referência para apoio político ou como reguladoras de aliança na sociedade apinayé." (Idem, p. 107)

${ }^{376}$ DA MATTA, Roberto, SEEGER, Anthony e VIVEIROS DE CASTRO, Eduardo; "A construção da pessoa nas sociedades indígenas brasileiras", in Boletim do Museu Nacional, n 32, maio de 1979, p. 3 (grifo dos autores).

${ }^{377}$ Idem, p. 10.
} 
Mas o melhor ainda estava por vir, o que conduziu à formulação do perspectivismo ameríndio; o acompanhamento etnográfico dessas "construções" e dessas "fabricações" conduziu a que se encontrasse uma razão, um "fundamento cosmológico" ${ }^{378}$, para essa ênfase dada por esses povos à corporalidade: é assim que eles cuidam da sua diferenciação não somente interna (às suas sociedades) mas em relação, principalmente, a todo o universo de seres, animais, plantas, deuses, espíritos, mortos, fenômenos metereológicos, acidentes geográficos, objetos e artefatos"alteridades", em suma- que eles percebem "habitar" o meio no qual eles vivem, a floresta.

Isso não é algo de fácil apreensão e merece um detalhamento maior. Ocorre que, para esses povos, esses outros seres possuem, também, como o demonstram os seus mitos, uma "humanidade", mas uma humanidade que se dá de forma perspectiva, o que quer dizer que não se trata de que exista a possibilidade de, simultaneamente, homens e esses outros seres "dialoguem" enquanto iguais_configurando um mero animismo-: as diferenças de espécie e a reciprocidade são sempre mantidas (ou devem ser sempre mantidas) e isso faz com que no momento em que a perspectiva humana é assumida por uma outra espécie qualquer-ou melhor, quando essa perspectiva passa a ser aquela que prevalece, numa situação, cotidiana, em que ambas perspectivas se encontram em situação de confronto ${ }^{379}$ —, os próprios humanos deixam de ser humanos, tornando-se a espécie que o tipo de relação de predação que eles mantém com aquela espécie que

378 VIVEIROS DE CASTRO, Eduardo; "Perspectivismo e multinaturalismo na América Indígena", in VIVEIROS DE CASTRO, Eduardo; A inconstância da alma selvagem; São Paulo, Cosac \& Naify, 2002, p. 387.

379 Tânia Stolze de Lima, parceira de Viveiros de Castro na descoberta do perspectivismo ameríndio, chama isso de "um regime binário", um no qual ocorre uma "disputa entre os humanos e alguma outra categoria de alteridade". (LIMA, Tania Stolze de; "O dois e seu múltiplo: reflexões sobre o perspectivismo em uma cosmologia tupi", in Mana-estudos de antropologia social, vol. 2, $\mathrm{n}^{\circ}$ 2, outubro de 1996, p. 34. 
assume a perspectiva humana, lhes determina. Do ponto de vista do homem, por exemplo, homens comem peixes e são comidos por onças, e peixes comem plantas; mas se, por acaso, passarmos a enxergar as coisas do ponto de vista do peixe, então o homem—que na perspectiva do homem come o peixe—, esse homem "vira"—é "visto como"—onça e a planta "vira", para esse peixe que é "homem”, peixe. É por isso que essa forma de ver o mundo, perspectivista, é também multinaturalista, como chama à atenção Viveiros de Castro, num artigo em que sintetiza a descoberta:

"a teoria perspectivista ameríndia está de fato (...) supondo uma multiplicidade de
representações sobre o mesmo mundo? Basta considerar o que dizem as etnografias, para
perceber que é o exato inverso que se passa: todos os seres vêem ('representam') o
mundo da mesma maneira—o que muda é o mundo que eles vêem. Os animais utilizam as
mesmas categorias e valores que os humanos: seus mundos, como o nosso, giram em
torno da caça e da pesca, da cozinha e das bebidas fermentadas, das primas cruzadas e da
guerra, dos ritos de iniciação, dos xamãs, chefes, espíritos etc. (...) Se a lua, as cobras e as
onças vêem os humanos como antas ou porcos selvagens, é porque, como nós, elas
comem antas e porcos selvagens, comida própria de gente. Só poderia ser assim, pois,
sendo gente em seu próprio departamento, os não-humanos vêem as coisas como 'a
gente' vê. Mas as coisas que eles vêem são outras: o que para nós é sangue, para o jaguar
é cauim; o que para as almas dos mortos é um cadáver podre, para nós é mandioca
pubando; o que vemos como um barreiro lamacento, para as antas é uma grande casa
cerimonial." 380 O que nela está em questão não é, como esse autor diz, logo em seguida, a existência de uma "diversidade de representações subjetivas e parciais, incidentes sobre uma natureza externa, una e total, indiferente à representação" mas "uma unidade representativa ou fenomenológica puramente pronominal, aplicada indiferentemente sobre uma diversidade real”, ou seja "uma só cultura, múltiplas 'naturezas'; epistemologia constante, ontologia variável—o perspectivismo é um multinaturalismo, pois uma perspectiva não é uma representação." ${ }^{381}$ E ainda: o perspectivismo, continua esse autor, é também um "relacionalismo"—e não "um relativismo"—na medida em que

\footnotetext{
${ }^{380}$ VIVEIROS DE CASTRO, Eduardo; “Perspectivismo e multinaturalismo ...”, op. cit., pp. 378-379 (grifos do autor).

${ }^{381}$ Idem p. 379.
} 
"o ponto de vista não é uma opinião subjetiva; não há nada de subjetivo nos conceitos de 'ontem' e 'amanhã', como não há nos de 'minha mãe' ou 'teu irmão'. O mundo real das diferentes espécies depende de seus pontos de vista porque o 'mundo' é composto das diferentes espécies, é o espaço abstrato de divergências entre elas enquanto pontos de vista: não há pontos de vista sobre as coisas-as coisas e os seres é que são pontos de vista. (...) A questão aqui, portanto, não é 'como os macacos vêem o mundo' (...), mas que mundo se exprime através dos macacos, de que mundo eles são o ponto de vista." $" 382$

Os povos ameríndios, portanto, estão imersos, dentro da sua forma de ver, num

universo em que múltiplas perspectivas estão, simultaneamente, em exercício, mas, mais do que em exercício, em disputa ${ }^{383}$, havendo sempre o risco de que, num contexto, cotidiano ou não, qualquer, uma perspectiva tome conta de outra que se lhe antepõe e que a antagoniza; e a forma como eles encontram para “jogar” essa disputa é através de todos esses rituais, de toda essa preocupação corporal $^{384}$. Diz, a respeito, Viveiros de Castro, que

${ }^{382}$ Idem, p. 384-385(grifos do autor). Isso , por sua vez, provavelmente está correlacionado ao fatoapontando um pouco antes no artigo-de que a condição de humanidade, para os ameríndios, não denota "uma espécie natural, mas a condição social da pessoa" e que a designação de "ser humano" e outras auto-designativas, para eles, funcionam "pragmatica quando não sintaticamente, menos como substantivos que como pronomes. Elas indicam a posição do sujeito; são um marcador enunciativo, não um nome" - sendo que daí decorre que "dizer que os animais e espíritos são gente é dizer que são pessoas; é atribuir aos não-humanos as capacidades de intencionalidade consciente e de agência que facultam a ocupação enunciativa do sujeito. Tais capacidades são reificadas na alma ou espírito de que esses não-humanos são dotados. É sujeito quem tem alma, e tem alma quem é capaz de um ponto de vista." (Idem, pp. 371-372, grifos dos autor).

${ }^{383}$ Stolze de Lima, no artigo já citado, sobre os juruna e a sua "caça aos porcos", diz, por exemplo que "o ponto de vista do Outro incorporado pelo sujeito representa uma virtualidade, que pode se atualizar ou não em função da ação efetuada por cada um. (...) Assim, o acontecimento que existe para os porcosque vêem os humanos como inimigos numa guerra - deve ser (em uma formulação a nosso ver, grosseira, mas, na verdade, bem adequada ao espírito dos juruna) reduzido a uma mentira pelos humanos-que vêem os porcos como caça. Na mesma medida em que os caçadores querem impor o seu ponto de vista aos porcos, estes não perderiam a chance de fazer o mesmo. Não se entregariam ao inimigo sem luta. Os caçadores, de sua parte, tampouco podem ignorar as disposições da caça. Uma luta entre caçadores e guerreiros está em curso" e "o infortúnio do caçador é o resvalamento da caçada em guerra. Cientes da dimensão sobrenatural que o ponto de vista dos porcos representa para eles, os humanos utilizam-se de meios através dos quais pretendem impedir toda possibilidade de os porcos virem a impor seu ponto de vista". (LIMA, Tânia Stolze de; “O dois e seu múltiplo...”, op. cit., pp. 37-38.). Na mesma linha, Viveiros de Castro aponta para uma "situação sobrenatural típica no mundo ameríndio" que "é o encontro, na floresta, entre um humano—sempre sozinho-e um ser que, visto primeiramente como um mero animal ou uma pessoa, revela-se como um espírito ou um morto, e fala com o homem": nessa situação, de acordo com os Achuar estudados por Anne-Christine Taylor, deve-se rapidamente dizer "'Eu também sou uma pessoa!...' Ou seja, deve-se afirmar o próprio ponto de vista; quando o humano diz que é uma pessoa, o que ele está dizendo é que ele é o $e u$, não o outro: a verdadeira pessoa aqui sou eu." (VIVEIROS DE CASTRO, Eduardo; "Perspectivismo e multinaturalism...”, op. cit., p. 397).

${ }^{384}$ Que, no caso da caça aos porcos juruna, pode ser encontrada desde as ações dos caçadores no ato da caça- “não se exprime o medo gritando, como se o caçador fosse a presa", não se lhes dirige a palavra.- 
"uma perspectiva não é uma representação porque as representações são propriedades do espírito, mas o ponto de vista está no corpo. Ser capaz de ocupar o ponto de vista é sem dúvida uma potência da alma, e os não-humanos são sujeitos na medida em que têm (ou são) um espírito; mas a diferença entre os pontos de vista-e um ponto de vista não é senão diferença—não está na alma. Esta, formalmente idêntica através das espécies, só enxerga a mesma coisa em toda parte; a diferença deve então ser dada pela especificidade dos corpos." 385

Mas o que é, exatamente, um corpo, nesse contexto? Viveiros de Castro responde, com

clareza: "não é sinônimo de fisiologia distintiva ou de anatomia característica; é um

conjunto de maneiras ou de modos de ser que constituem um habitus. Entre a subjetividade formal das almas e a materialidade substancial dos organismos, há esse plano central que é o corpo como feixe de afecções e capacidades, e que é a origem das perspectivas."386 Daí é que se torna possível explicar a famosa anedota relatada por

Lévi-Strauss, de que, conforme cita Viveiros de Castro,

“'Nas Grandes Antilhas, alguns anos após a descoberta da América, enquanto os espanhóis enviavam comissões de inquérito para investigar se os indígenas tinham ou não uma alma, estes se dedicavam a afogar os brancos que aprisionavam, a fim de verificar, por uma demorada observação, se seus cadáveres eram ou não sujeitos à putrefação","387:

ora, o que ocorria é que

"para os europeus, tratava-se de decidir se os índios tinham alma; para os índios, de saber que tipo de corpo tinham os outros. O grande diacrítico, o sítio da diferença perspectiva para os europeus é a alma (os índios são homens ou animais?); para os índios é o corpo

até a observação de como o predador deve se comportar após efetuada a caça (cf. LIMA, Tânia Stolze de; "O dois e seu múltiplo...", op. cit., p. 38) No caso dos rituais, em que os ameríndios geralmente se adornam com" plumas, cores, grafismos, máscaras e outras próteses animais", o que ocorre é que é assim se "animalizando" que ele se "dá a ver a outrem": "o homem ritualmente vestido de animal é a contrapartida do animal sobrenaturalmente nu: o primeiro, transformado em animal, revela para si mesmo a distintividade 'natural' do seu corpo; o segundo, despido de sua forma exterior e se revelando como humano, mostra a semelhança "sobrenatural' dos espíritos", diz Viveiros de Castro. (VIVEIROS DE CASTRO, Eduardo; "Perspectivismo e multinaturalismo...", op. cit., pp. 388-389).

${ }^{385}$ Idem, pp 379-380.

${ }^{386}$ Idem, p. 380. Nesse sentido, Tânia Stolze de Lima diz, em um outro texto seu, que, no caso dos juruna, "a noção juruna tem o corpo como uma realidade do mesmo tipo que as relações de parentesco. Corpo e alma não são substâncias, mas relações ou posições, ou ainda perspectivas." (LIMA, Tânia Stolze de; "O que é um corpo?", in Religião e Sociedade, vol. 22, no 1, 2002, pp. 11-12.) Uma comparação, contudo, desse texto de Stolze de Lima com a última parte do artigo de Viveiros de Castro, intitulada "O corpo selvagem", faz entrever diferenças que não considero que seja pertinente abordar neste trabalho. Outros dois textos que trazem uma boa discussão sobre o corpo nas sociedades ameríndias são os de Aparecida Vilaça, "Fazendo corpos: reflexões sobre morte e canibalismo entre os wari' à luz do perspectivismo" e de Carlos Fausto, "Banquete de gente: comensalidade e canibalismo na Amazônia" (respectivamente em Revista de Antropologia, vol. 41, n 1, São Paulo, 1998 e em Mana, vol. 8, $\mathrm{n}^{\circ}$ 2.)

${ }^{387}$ VIVEIROS DE CASTRO, Eduardo; "Perspectivismo e multinaturalismo...”, op. cit., p. 368. 
(os europeus são homens ou espíritos?). Os europeus não duvidavam que os índios tivessem corpos - animais também os têm; os índios, que os europeus tivessem almasanimais também as têm. O que os índios queriam saber era se o corpo daquelas 'almas' era capaz das mesmas afecções e maneiras que os seus: se era um corpo humano ou um corpo de espírito, imputrescível e proteiforme." ${ }^{388}$

Aproveitando o tema das diferenças entre europeus e ameríndios-a cada instante evocadas no texto-síntese de Viveiros de Castro a respeito do perspectivismo ameríndio—e voltando para a problemática do sujeito tal como presente em Foucault e na psicanálise lacaniana, podemos dizer que o equivalente do divã do psicanalistaonde, como vimos, se trata de tornar-se sujeito encontrando, por meio da palavra, aquilo que, no corpo, nos torna singulares-, no contexto das sociedades ameríndias, seriam todos esses trabalhos corporais, rituais ou cotidianos, onde se trata não de tornar-se sujeito, mas de não deixar de sê-lo, dando assim, essas sociedades, um exemplo literal de uma cultura em que seus membros se empenham em "cuidar de si". Cabe lembrar que essas sociedades, no que diz respeito ao poder, são sociedades que prescindem de Estados: nelas, a obediência é algo que não existe, tal como relembra Joanna Overing a partir do livro clássico de Pierre Clastres sobre as sociedades contra o Estado ${ }^{389}$, num belo texto sobre o "senso de comunidade" entre os cubeo, investigados por Irving Goldman na década de ‘60, e os piaroa da Guiana, onde, também, diz que

\footnotetext{
“à diferença da tendência que, no pensamento político e sociológico ocidental, equaciona 'o social' com a limitação imposta por uma coletividade e com relações de dominação, os índios das terras baixas, em sua teoria política, tendem a insistir no oposto, onde 'o social' (ao menos em seu sentido positivo, tal como expresso pela relação de vida comunitária) é visto como o meio pelo qual as pessoas podem ativamente evitar o estabelecimento de relações de dominância, ${ }^{, 390}$
}

\footnotetext{
${ }^{388}$ Idem, p. 381.

${ }^{389}$ CLASTRES, Pierre; A sociedade contra o Estado; op. cit. (cf. nota no 14 do primeiro capítulo). "Se existe alguma coisa completamente estranha a um índio, é a idéia de dar uma ordem ou de ter de obedecer, exceto em circunstâncias muito especiais como em uma expedição guerreira", diz esse autor. (Idem, p. 28)

390 OVERING, Joanna; "A estética da produção: o senso de comunidade entre os cubeo e os piaroa", in Revista de Antropologia, vol. 34, 1991, p. 9.
} 
e aponta para uma "intenção moral/estética" como motor disso ${ }^{391}$.

É claro: aqui estamos já falando de uma (possível) dominação interna e não da questão, cosmológica, relativa a não se deixar impregnar por um ponto de vista que não o próprio, humano. Mas, não seria uma tremenda contradição o não se deixar dessubjetivizar pelas outras espécies, deixando-se-o pelos outros membros da sociedade? O que quero dizer, com isso, é que o perspectivismo ameríndio não deveria ser desconectado, enquanto modo de apreensão do cosmos, enquanto epistemologia e ontologia, de uma teoria política; e que o que promoveria tal vínculo é o sujeito que está presente, igualmente, em ambas-ontologia e teoria política-, determinando-as. Assim, podemos pensar que esse pensamento não se encontra distante das palavras de Sócrates, recolhidas por Foucault, pelas quais, a Alcibíades-que queria ser o governante de Atenas-, ele recomendava que, antes, era necessário que ele fosse capaz de cuidar de si, ou seja, de reconhecer-se como sujeito. O texto platônico aponta para uma forma de conhecimento outra—que não se destaca da pessoa que conhece e do grau de liberdade que essa pessoa quer para si e para os outros que o cercam e que com ele se relacionam, um conhecimento da alma humana enquanto sujeito-e, nisso, não se distancia do xamanismo dos povos ameríndios, onde o xamã, sendo aquela figura que consegue transitar entre as diversas perspectivas sem o risco de se deixar capturar por aquelas que não são humanas—e, assim, poder socorrer aquelas almas que, sendo (ou tendo sido) humanas, estão sob o poder de uma outra subjetividade, não-humana e,

\footnotetext{
${ }^{391}$ Esse texto, gerado no contexto da etnologia indígena sul-americana, é recheado de ressonâncias foucaultianas, tais como as noções de "estilo de vida" - levantada inicialmente por Goldman —e a própria redefinição do termo "estética", como "categoria moral e política", almejada pela autora para poder entender o sentido do social nos piaroa, por ela estudados, que remete fortemente à "estética da existência" percebida por Foucault na Grécia Antiga e aventada, nos seus escritos, desde a "atitude crítica", como antídoto à governamentalidade dos dia atuais (cf, em especial, FOUCAULT, Michel; "Une esthétique de l'existence", in $D E I I$, texto n³57, pp. 1549-1554).
} 
portanto, definham, ou então, se tornam perigosas ${ }^{392}$ - é o detentor de uma sabedoria na qual

\begin{abstract}
“a boa interpretação (...) é aquela que consegue ver cada evento como sendo, em verdade, uma ação, uma expressão de estados ou predicados intencionais de algum agente. $\mathrm{O}$ sucesso interpretativo é diretamente proporcional à ordem de intencionalidade que se consegue atribuir ao objeto ou noema. Um ente ou um estado de coisas que não se presta à subjetivação, ou seja, à determinação de sua relação social com aquele que conhece, é xamanísticamente insignificante—é um resíduo epistêmico, um 'fator impessoal', resistente ao conhecimento preciso." ${ }^{\text {393 }}$
\end{abstract}

Que nome poderíamos dar a esse conhecimento comum? Bom, relacioná-lo a um terceiro, à clínica lacaniana a partir do que foi exposto na seção anterior deste capítulo, a essa atividade que se auto-denomina "uma ética", creio que ajuda a que encontremos uma resposta. Jorge Forbes, na sua conferência intitulada "O tempo da sessão", inicia fazendo uma referência à psicanálise ser, conforme Lacan-e conforme ele, Forbesuma "ética do desejo". Mas, conforme ele próprio chama à atenção "é muito fácil repetir essa expressão": "devemos ser mais exigentes e explicitar o que estamos tratando"394. O leitor que acompanhar o que ele diz ao longo dessa conferência irá ver que ela termina com esse autor dizendo que essa psicanálise se entende como uma ética na medida em que ela vê como "necessário retirar um analisando da covardia perante uma conclusão precipitada, fazê-lo concluir para depois compreender"; assim,

“o analisando conta a sua história depois da conclusão, não antes. É uma inversão radical do que se pensava. Há uma tentativa de fazer com que a pessoa se decida a partir desse

\footnotetext{
${ }^{392}$ O xamã tem uma função importante na caça aos porcos juruna, conforme relata Stolze de Lima—ela de fato está "no campo de ação do xamã", pois "quem estiver com desejo de comer dessa caça pode, dizse, pedir ao xamã para atrair porcos", o que é feito por este mediante um cigarro que ele acende e oferece ao "porco-xamã", que é quem, por sua vez, vai conduzir os caçadores ao lugar onde estão os porcos. (Cf. LIMA, Tânia Stolze de; "O dois e seu múltiplo...", op. cit., pp. 21-26) Viveiros de Castro, por sua vez, vai dizer que os xamãs, "vendo os seres não-humanos como estes se vêem (como humanos) (...) são capazes de assumir o papel de interlocutores ativos no diálogo transespecífico; sobretudo eles são capazes de voltar para contar a história, algo que os leigos dificilmente podem fazer. O encontro ou o intercâmbio de perspectivas é um processo perigoso, e uma arte política—uma diplomacia. Se o 'multiculturalismo' ocidental é o relativismo como política pública, o perspectivismo xamânico ameríndio é o multinaturalismo como política cósmica." (VIVEIROS DE CASTRO, Eduardo; "Perspectivismo e multinaturalismo...", op. cit., p. 358).

${ }^{393}$ Idem, pp. 359-360, grifo do autor.

${ }^{394}$ FORBES, Jorge; Você quer o que deseja?; op. cit., p. 123.
} 
ponto incompleto. Esse ponto incompleto é o ponto do desejo. Porque é o desejo que diz: o mundo é incompleto. Se o mundo fosse completo, as pessoas não desejariam. O desejo sempre aponta algo que está faltando. 'Eu desejo' é a enunciação da falta. Em algum momento, numa sessão, ocorre essa afirmação, que não é preparada, não é raciocinada. É uma afirmação precipitada, cujo entendimento é posterior. (...) Alguns poderiam dizer: que é chato fazer análise! Eu estava no gozo do meu pensamento, fazendo conjeturas... (...) No momento em que o analista retira o analisando do gozo, no momento em que este deixa cair o gozo, passa a ser o enunciador universal. Por um momento, o coletivo nada mais é do que o sujeito do individual." 395

Dando ao conhecimento do xamã ameríndio-esse guardião do perspectivismo — e de Sócrates—esse guardião da alma-sujeito—o nome comum de "ética", podemos resolver duas dificuldades terminológicas que foram enfrentadas tanto por Foucault, ao investigar a Antigüidade, em busca de formas de relacionamento que escapassem ao poder pastoral, quanto pela etnologia brasileira, ao destrinchar as “anomalias" apresentadas pelos povos das terras baixas amazônicas: o cuidado de si ${ }^{396}$ é, em verdade, uma ética-e é assim como Foucault a ela se refere em uma das suas últimas entrevistas, "A ética do cuidado de si como prática de liberdade"-, tanto quanto o poderia ser essa "ideologia da corporalidade" ameríndia de que Roberto da Matta foi o primeiro a falar e da qual surgiu a melhor compreensão do perspectivismo ameríndio.

\footnotetext{
${ }^{395}$ Idem, p. 135. Nessa última frase, como aponta o autor, há uma referência que Lacan, no seu texto "O tempo lógico e a asserção de certeza antecipada" fez à Psicologia das massas, de Freud. No caso específico da palestra, essa idéia, de origem freudiana—insisto—, de que "o coletivo não é nada senão o sujeito do individual", vem após o relato que Forbes faz das palavras dirigidas por De Gaulle aos franceses, quando ele se encontrava na Inglaterra e comandava de lá a resistência à ocupação nazista da França. Diz Forbes: "É famoso esse discurso. É um discurso precipitado. Ele antecipa um ganho. Um discurso visionário. Ousado. Arriscado. $\mathrm{O}$ discurso de um nome. Talvez muitos perguntem: 'Mas o que tem a ver o discurso do De Gaulle com o paciente de uma análise?' (...) Tudo a ver. Primeiro: por que nos emociona? Um analista, grande amigo meu, François Leguil, costuma dizer: 'Diante disso, eu jamais me envergonho de chorar.' Por quê? Porque a própria essência do homem, essa espécie tão arrebentável, só tem a palavra. Essa palavra com que a gente trabalha para se defender e viver. A nossa arma, em última análise, é a palavra. E quando alguém usa essa palavra fazendo dela ato e não blábláblá, emociona." (Idem, p. 134).

${ }^{396}$ Cf. a caracterização que dela fiz, anteriormente, como uma "tradição cultural", na nota n 284.
} 


\title{
5. Conclusão
}

O sujeito na sua relação com a verdade: eis o que, no fundo-não é a primeira vez que Foucault afirma isso ${ }^{397}$ — "sempre foi” o seu assunto, o fulcro do seu interesse. Diz ele numa entrevista de 1984:

\begin{abstract}
"meu problema sempre foi, como eu dizia no começo: como o sujeito entra num certo jogo de verdade. Meu primeiro problema foi: como é que se dá, por exemplo, que a loucura tenha sido problematizada a partir de um certo momento e em seguida de um certo número de processos como uma doença decorrente de uma certa medicina? Como o sujeito louco foi posto nesse jogo de verdade definido por um saber ou um modelo médico? E foi fazendo essa análise que eu me dei conta que, contrariamente àquilo que era um pouco o hábito nessa época—por volta do começo dos anos '60—não era simplesmente falando de ideologia que se podia dar conta desse fenômeno. De fato, havia práticas-essencialmente essa grande prática do internamento que foi desenvolvida à partir do começo do século XVII e que tinha sido a condição para a inserção do sujeito louco nesse jogo de verdade-que me remetia ao problema das instituições de poder, muito mais do que ao problema da ideologia. Foi assim que eu fui levado a levantar o problema saber/poder, que é para mim não o problema fundamental, mas um instrumento que permite analisar da maneira que me parece a mais exata o problema das relações entre sujeito e jogos de verdade." ${ }^{398}$
\end{abstract}

E, tal como Sócrates no Alcibíades-que desmembrou o "cuidado de si", indagando primeiro sobre o que é o "si" e, depois, sobre o "cuidado"399_—é possível desmembrar os dois pólos dessa equação, tal como o próprio Foucault faz, na sequiência dessa entrevista. O sujeito? Bom, diz ele,

“o sujeito não é uma substância. É uma forma, e essa forma não é sobretudo nem sempre idêntica a si mesmo. Não se tem consigo mesmo o mesmo tipo de relação na hora em que se constitui a si mesmo como sujeito político que vai votar ou que toma a palavra numa assembléia e na hora em que se procura realizar o desejo dentro de uma relação sexual.

\footnotetext{
${ }^{397}$ Cf. infra, notas $n^{\text {o }} 11$ e 173-175.

${ }^{398}$ FOUCAULT, Michel; "L'éthique du souci de soi comme pratique de liberte", in $D E I I$, texto n 356 , pp. 1536-1537)

${ }^{399}$ Cf. infra, notas no 307 e 308, bem como PLATON; Alcibiade (et alli.); Paris, Gallimard, 1998, pp. 62 e seguintes.
} 
Há sem dúvida relações e interferências entre essas diferentes formas de sujeito, mas não se está na presença do mesmo tipo de sujeito."400

E a verdade? Essa é algo que esse "historiador da verdade" pode, finalmente, sintetizar

da seguinte maneira:

"por que a verdade? E por que é que se preocupa da verdade, e até mesmo mais do que de si mesmo? E por que é que se preocupa de si somente através da preocupação com a verdade? Eu creio que se toca aí numa questão que é fundamental e que é, eu diria, a questão do Ocidente: o que foi que fez que toda a cultura ocidental se tenha posto a girar em torno a essa obrigação da verdade, que tomou todo um bando de formas diferentes? As coisas sendo o que elas são, nada até o presente tem podido mostrar que se poderia definir uma estratégia exterior a ela. É bem nesse campo da obrigação de verdade que podemos nos movimentar, de uma maneira ou de outra, por vezes contra os efeitos de dominação que podem estar ligados a estruturas de verdade ou a instituições que são encarregadas da verdade." 401

E eis onde se desenha, claramente, uma (nova) política: na seqüência do que ele diz,

pois

"o mesmo ocorre na esfera da política onde se podia fazer a crítica do político-a partir, por exemplo, das consequiências do estado de dominação dessa política indevida-mas não se podia fazê-lo a não ser jogando um certo jogo de verdade, mostrando quais são as consequiências, mostrando que há outras possibilidades racionais, ensinando às pessoas aquilo que elas não sabem a respeito da sua própria situação, sobre suas condições de trabalho, sobre a sua exploração." 402

Temos, então, nesse breve trecho dessa importante entrevista, todos os elementos que, de início, levantamos: uma unidade de trajetória, ou melhor, uma trajetória que não apresenta rupturas radicais; e um propósito, político, de transformação.

Quanto ao primeiro desses, o que de mais se pode dizer é que se trata da perspectiva que tem inspirado o que de melhor se tem produzido sobre Foucault nos últimos anos. Exemplo disso é o livro Michel Foucault, l'inquiétude de l'histoire, de Mathieu Potte-Bonneville, onde esse autor chama a atenção para os elementos de

${ }^{400}$ FOUCAULT, Michel; “L'éthique du souci de soi...”, op, cit., pp. 1537-1538)

${ }^{401}$ Idem, p. 1542-1543.

${ }^{402}$ Idem, p. 1543. Creio que não se trata mais, aqui, nessa fala, de uma defesa do papel dos intelectuais enquanto portadores de um universal, tal como vimos que Foucault critica nos anos '70, mas da noção de que as lutas que existem se dão no plano das idéias, ou melhor, que, como ele disse a Eribon, dessa coisa, o pensamento, que "é preciso parar de considerar como vento" (cf. nota n 73 do capítulo 2). 
subjetividade que se encontravam já presentes na História da loucura, primeiro livro de

Foucault, de 1961:

"o livro de 1961 está longe de contar, simplesmente, a história de uma objetivação forçada: porque o louco participa do conhecimento que se elabora a seu respeito; porque, também, a longa análise do 'tratamento moral' iniciado por Pinel atende de maneira insistente à dimensão da subjetividade. Só que, se a figura do sujeito está satisfatoriamente presente, ela não pode entretanto se manter como tal, e até o final一até a constituição prática de uma interioridade suscetível de durar e de estender suas potencialidades próprias no interior do campo normativo. O propósito de Foucault é muito mais o de mostrar que, se a modernidade se remete ao sujeito louco, exortando-o a que se conheça e a que se cure, ela interdita contudo a sua posição verdadeira. Interdição que assume, de fato, duas formas. De um lado, o estatuto do sujeito atribuído ao louco é severamente limitado e finalmente dissipado por sua inscrição sob as categorias do objeto; é a tese conclusiva do livro; mas do outro lado, no momento em que, com Goya ou Sade, uma linguagem da loucura penetra nos interstícios da objetividade e acha de se enunciar em primeira pessoa, é ao preço de uma ruína deliberada do sujeito enunciante, que se perde no grito ou se desfaz no anônimo."

A "arquitetura" desse livro, analisada por esse autor, revela que, nele, as referências feitas a obras literárias e artísticas e aos seus autores se dividem em duas formas diferentes: por um lado, a referência precisa, a tal pintura ou livro-é o caso das referências a Bosch, a Racine, a Diderot e a Sade_-, dentro de uma análise que ajuda a elucidar uma determinada tendência, um determinado contexto, daí uma pontualidade quanto a essas citações; mas, por outro, uma "lista" de nomes que se repete e se espalha ao longo de todo o livro, sem que se explicitem obras específicas; uma lista apenas, mas "insistente", em que figuram Hölderlin, Nietzsche, Van Gogh, Artaud, Nerval e Roussel. O autor se pergunta: "por que manter Nietzsche, Artaud ou Nerval nesse relativo mutismo, ao passo que a sua presença assombra literalmente o livro? Inversamente, por que lhes conceder uma tal importância, se essa insistência não pode se desdobrar numa análise conseqüente de sua contribuição à história da loucura?"404 A resposta definitiva só vem um pouco mais à frente quando é lembrado que o título

\footnotetext{
${ }^{403}$ POTTE-BONNEVILLE, Mathieu; Michel Foucault, l'inquiétude de l'histoire; Paris, PUF, 2004, p. 132.

${ }^{404}$ Idem, p. 77.
} 
original dessa obra era Loucura e desrazão e que esses autores, sujeitos criadores de obras, também, enlouqueceram e, assim, as suas existências "constituem o ponto de

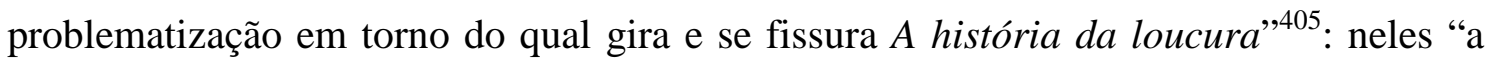
desrazão ressurge, não por sua identidade ou sua proximidade com a loucura, mas pelo rigor da alternativa que, ao contrário, dela separa. 'Lá onde há obra, não há loucura; e contudo, a loucura é contemporânea da obra, dado que ela inaugura o tempo da sua verdade"”, diz Potte-Bonneville, citando um trecho do livro de Foucault ${ }^{406}$.

Esses autores carregam consigo, no seu "silêncio" ao longo da História da loucura—e, de resto, à exceção de Roussel, ao longo da "obra" de Foucault, pois Nietzsche nunca recebeu de Foucault uma análise sistemática, como ele mesmo aponta $^{407}$ - a voz do sujeito que está presente nessa relação de poder específica que se configurou em determinado momento e a que foi dado o nome de "loucura". Não há como não dizer que a sua presença, ou melhor, a sua onipresença no livro e nos seus "ditos e escritos"-Foucault nunca abriu mão desses "artistas"—não seja um exemplo desse tema, do sujeito e da verdade, da reflexividade de si para si em face aos jogos de verdade, que ele diz ter sido sempre o seu. E isso nos leva a pensar que também outros autores, esses que lhe permitiram "desprender-se da sua formação universitária"408, façam parte desse elenco, ainda que não tenham, todos, enlouquecido. Tome-se o exemplo de Georges Bataille, a respeito de quem Foucault escreveu no início dos anos '60 um importante texto ${ }^{409}$, e do retrato que dele foi feito por Eliane Robert Moraes em O corpo impossível: o do fundador de uma revista, Acéphale, em cujo frontispício se

\footnotetext{
${ }^{405}$ Idem, p. 87.

${ }^{406}$ Idem, p. 88.

${ }^{407}$ FOUCAULT, Michel; "Le retour de la morale", in DE II, texto no 354, p. 1522.

${ }^{408}$ Cf. infra, nota $n^{\circ} 328$.

${ }^{409}$ Cf. FOUCAULT, Michel; "Préface à la transgression", in $D E I$, texto no 13, pp. 261-278.
} 
encontrava sempre a "figura-totem" de um corpo sem cabeça e em cujo interior um conteúdo que

\begin{abstract}
"parece sintetizar todo o processo de fragmentação da anatomia humana levado a termo desde as últimas décadas do século XIX, ao mesmo tempo em que insinuava seu ponto terminal por meio da reversibilidade da imagem original do decapitado: se a negação do homem começara quando lhe tiraram o corpo, ela agora era reiterada em seu termo contrário. Para realmente 'desumanizar' o homem, tal como insistiram os artistas e escritores modernistas, não bastava apenas cortar sua cabeça: era preciso também abandoná-la por completo."
\end{abstract}

Se o tema da subjetividade-esse tema ao qual Foucault chega após todo o desvio que ele teve que realizar por conta da questão do poder e que ele encontra, ou melhor, destila, em conjunto com uma nova noção de liberdade somente tardiamente, como vimos-, como procurei mostrar, é um tema que está em sintonia com dois percursos intelectuais que giram em torno da questão do (ou de um) corpo, temos nesse acéfalo batailleano, nesse corpo "'que foge da cabeça como o condenado da prisão"”, e na forte influência de Bataille sobre Foucault, mais um exemplo de que a procura desse último foi sempre uma só. Como diz Moraes, em torno dessa figura:

\begin{abstract}
“essa mutilação não é apenas negativa: lembremos que, na definição de Bataille, 'o acéfalo não é eu; ele é mais eu que eu'. A ausência da cabeça não significa portanto ausência de vida, e a ferida da decapitação abre novas possibilidades de sentido para a existência humana. Ademais, o corpo vivo e potente do decapitado atesta que a cabeça é apenas um de seus limites orgânicos. Restam as outras extremidades. Ou, simplesmente, o resto do homem.",411
\end{abstract}

Há muito a se encontrar, na leitura da produção de Foucault dos anos '60, partindo do tema, tardio, da subjetividade e da liberdade do sujeito face aos dizeres verdadeiros. Em verdade, tudo, e, nisso, discordo de Roberto Machado e do seu esforço reiterado de mostrar as "complementaridades" entre os "diversos" Foucaults; entre os escritos arqueológicos, por exemplo, e o que Foucault escreveu sobre literatura, na

\footnotetext{
${ }^{410}$ MORAES, Eliane Robert; $O$ corpo impossível—a decomposição da figura humana de Lautréamont a Bataille; São Paulo, FAPESP/lluminuras, 2002, p. 89.

${ }^{411}$ Idem, p. 187.
} 
década de '60, entre "literatura e filosofia", como se o que fosse fundamental permanecesse no âmbito de uma "filosofia" que, à época, estava contida na "arqueologia do saber"-_por que não se pode desconsiderar essa reflexão sobre literatura quando se quer compreender a filosofia de Foucault?", pergunta ele na introdução do seu livro Foucault, a filosofia e a literatura" ${ }^{412}$, ao que responde que "em primeiro lugar, seu trabalho com a literatura acompanhou os deslocamentos temáticos de suas pesquisas, seguindo de perto as inflexões das análises arqueológicas" e que

\begin{abstract}
"em segundo lugar, esse seu interesse pela literatura significou um complemento de suas análises arqueológicas, na medida em que, ao valorizá-la como contestação do humanismo das ciências do homem e das filosofias modernas, revelou mais claramente o aspecto positivo, afirmativo, o lado que diz sim, (...) de um pensamento que em suas pesquisas sobre as ciências ou pseudociências mostrou-se profundamente negativo, crítico, demolidor" ${ }^{\prime 413}$.
\end{abstract}

Ora, o que sempre interessou Foucault não consistiu na construção de um edifício filosófico, de mais um sistema ou "maquinaria filosófica" e sim, na transformação política e, nesse sentido, esses artistas e escritores "loucos", ou quase, a respeito de quem escreveu bastante nos anos '60-“"ocupando a quase totalidade dos artigos desse período", como nota Machado-merecem ser vistos, mais, como existências e obras, vozes, de sujeitos que lutaram, com o seu pensamento e a sua crítica, por uma liberdade do homem; que tentaram dizer que é possível uma outra forma de ser. Merecem ser vistos como parceiros de Foucault na atividade de diagnosticar o presente, que, para esse último, conforme diz em 1983,

"não consiste em caracterizar simplesmente o que somos, mas, acompanhando as linhas de fragilidade do presente, em chegar a alcançar por onde isso que é e como isso que é poderia não ser mais isso que é. E é nesse sentido que a descrição (desse) deve ser feita sempre segundo essa espécie de fratura virtual, que abre um espaço de liberdade, entendido como espaço de liberdade concreta, isto é, de transformação possível." ${ }^{414}$

\footnotetext{
${ }^{412}$ MACHADO, Roberto; Foucault, a filosofia e a literatura; Rio de Janeiro, Jorge Zahar, 2001, p. 12.

${ }^{413}$ Idem, ibid.

${ }^{414}$ FOUCAULT, Michel; "Structuralisme et poststructuralisme”, in DE II, texto n ${ }^{\text {o } 330, ~ p p . ~ 1267-1268 . ~}$
} 
Foucault precisou, em seguida à arqueologia do saber e aos seus escritossimultâneos—-sobre literatura e sobre esses artistas "loucos", fazer o longo desvio a respeito do poder, pois percebeu que era disso o que se tratava, o tempo inteiro; e para chegar à conclusão-que nos remete de volta a esses sujeitos livre-pensantes, precursores onipresentes que, não obstante, em muitos casos, sucumbiram à "verdade da loucura"- de que esse poder pode ser definido como jogo, como jogos, "entre liberdades" ${ }^{415}$, pois "não pode haver relações de poder a não ser na medida em que os sujeitos são livres". Compreende-se, então, a afirmação de um "otimismo absoluto": "se há relações de poder através de todo campo social, é porque há liberdade em todo canto." 416

${ }^{415}$ FOUCAULT, Michel; "L'éthique du souci de soi comme pratique de liberte”, op. cit. p. 1547.

${ }^{416}$ Idem, p. 1539. 


\section{REFERÊNCIAS}

AGAMBEN, Giorgio; Homo sacer-o poder soberano e a vida nua I; Belo Horizonte, Editora UFMG/Humanitas, 2002.

ARENDT, Hannah; "O que é liberdade?", in ARENDT, Hannah; Entre passado e presente; São Paulo, Perspectiva, 2005.

CLASTRES, Pierre; A sociedade contra o social; São Paulo, Cosac\&Naify, 2003.

MUCHAIL, Salma Tannus; Foucault, simplesmente—textos reunidos; São Paulo, Edições Loyola, 2004.

DA MATTA, Roberto; “The Apinayé relationship system: terminology and ideology", in MAYBURY-LEWIS, David (coord.); Dialectical societiesthe Gê and the Bororo of Central Brazil; Cambridge, Harvard University Press, 1979.

DA MATTA, Roberto, SEEGER, Anthony e VIVEIROS DE CASTRO, Eduardo; "A construção da pessoa nas sociedades indígenas brasileiras", in Boletim do Museu Nacional, $\mathrm{n}^{\circ}$ 32, maio de 1979.

ERIBON, Didier; Michel Foucault e seus contemporâneos; Rio de Janeiro, Jorge Zahar, 1996.

FAUSTO, Carlos; "Banquete de gente: comensalidade e canibalismo na Amazônia", in Mana, vol. 8, nº 2.

FIMIANI, Mariapaola; Foucault et Kant_critique, clinique, éthique ; Paris, L'Harmattan, 1998.

FORBES, Jorge; Você quer o que deseja?; Rio de Janeiro, Bestseller, 2003.

FORBES, Jorge, REALE JÚNIOR, Miguel e FERRAZ JÚNIOR, Tércio Sampaio; A invenção do futuro; Barueri, Manole, 2005. 
FOUCAULT, Michel; «À propos de la généalogie de l'éthique : un aperçu d'un travail en cours », in DE II, texto n ${ }^{\circ} 344$, pp. 1428-1450. (1984)

;“À quoi rêvent lês iraniens?”, in DE II, texto n $245, \mathrm{pp}$. 688-695. (1978)

; A arqueologia do saber ; Rio de Janeiro, Forense Universitária, 1986.

; « Le chah a cent ans de retard », in DE II, texto $\mathrm{n}^{\circ} 243$, pp. 679-683. (1978)

; Dits et écrits, vols. I et II, édition établie sous la direction de Daniel Defert et François Ewald avec la collaboration de Jacques Lagrange ; Paris, Quarto-Gallimard, 2001.

; «Du gouvernemente des vivants », in DE II, texto $\mathrm{n}^{\circ} 289$, pp. 944-949. (1980)

; Em defesa da sociedade_curso no Collège de France (1975-1976); São Paulo, Martins Fontes, 2002.

; « Entretien avec Michel Foucault », in DE II, texto n ${ }^{\circ} 192$, pp. 140-160. (1977)

; "Entretien avec Michel Foucault", in DE II, texto n', 281, pp. 860-915. (1980)

; «Une esthétique de l'existence », in $D E I I$, texto $\mathrm{n}^{\circ} 357$, pp. 1549-1554. (1984)

; "Est-il donc important de penser?", in DE II, texto n' 296, pp. 997-1001. (1981)

; "L'éthique du souci de soi comme pratique de liberté », in DE II, texto ${ }^{\circ} 356$, pp. 1527-1549. (1984) 
; "Face aux gouvernements, les droits de l'homme", in $D E$ II, texto $\mathrm{n}^{\mathrm{o}} 355$, pp. 1526-1527. (1984)

; "La fonction politique de l'intellectuel", in $D E I I$, texto $\mathrm{n}^{\circ}$ 184, pp. 109-114. (1976)

; "Foucault", in DE II, texto n 345, pp. 1450-1455. (1984)

; A hermenêutica do sujeito-curso no Collège de France (1981-1982) ; São Paulo, Martins Fontes, 2004.

; Histoire de la sexualité, vol. I-La volonté de savoir; Paris, Gallimard, 2004.

; Histoire de la sexualité, vol. II-L'usage des plaisirs; Paris, Gallimard, 2004.

; Histoire de la sexualité, vol. III-Le souci de soi ; Paris, Gallimard, 2004.

; «Les intellectuels et le pouvoir », in $D E I$, texto $\mathrm{n}^{\circ} 106$, pp. 1174-1184. (1972) ; “Inutile de se soulever?", in DE II, texto n 269, pp. 790794. (1978) ; «Le jeu de Michel Foucault (entretien sur L'histoire de la sexualité », in DE II, texto n 206 , pp. 298-329. (1977) ; « Lacan, le 'liberateur' de la psychanalyse », in DE II, texto $\mathrm{n}^{\mathrm{o}} 299$, pp. 1023-1024. (1981)

717-719. (1978)

; « Lettre de Foucault à L'Unità », in DE II, texto n 254, pp.

; "Lettre ouverte à Mehdi Bazargan", in DE II, texto no 265, pp. 780-783. (1979) 
806-818. (1979)

; « Luttes autour des prisons », in $D E I I$, texto $\mathrm{n}^{\circ} 273$, pp.

; "Les mailles du pouvoir", in DE II, texto n'297, pp. 1001-

1021. (1981)

; «Méthodologie pour la connaissance du monde : comment

se débarrasser du marxisme », in DE II, texto n 235, pp. 595-618. (1978)

; «Michel Foucault et le zen : un séjour dans un temple

zen », in DE II, texto n ${ }^{\circ} 236$, pp. 618-624. (1978)

; "Naissance de la biopolitique", in DE II, texto n ${ }^{\circ} 274$, pp.

818-826. (1979)

; Naissance de la biopolitique-cours au Collège de France, 1978-1979; Paris, Gallimard-Seuil, 2004.

; O Nascimento da clínica; Rio de Janeiro, Forense

Universitára, 2004.

; « Nietzsche, la généalogie, l'histoire », in $D E I$, texto $\mathrm{n}^{\circ}$ 84, pp. 1004-1025. (1970)

; "'Omnes et singulatim': vers une critique de la raison politique", in DE II, texto $\mathrm{n}^{\circ} 291$, pp. 953-981. (1981)

; A ordem do discurso ; São Paulo, Loyola, 1999.

; As palavras e as coisas-uma arqueologia da ciências humanas; São Paulo, Martins Fontes, 2002.

; "Le philosophe masqué", in $D E I I$, texto n 285, pp. 923-

930. (1980) 
; "La philosophie analytique de la politique", in $D E I I$, texto $\mathrm{n}^{\mathrm{o}} 232$, pp. 534-552. (1978)

; « Polémique, politique et problematizations », in DE II, texto $\mathrm{n}^{\circ} 342$, pp. 1410-1418. (1984)

; "Politique et éthique: une interview", in $D E I I$, texto $\mathrm{n}^{\circ}$ 341, pp. 1403-1410. (1984)

; "La Pologne et après ?", in $D E I I$, texto n ${ }^{\circ} 334$, pp. 1315-

1341. (1983)

; "Pour une morale de l'inconfort", in DE II, texto n' 266, pp. 783-788. (1979)

; «Précisions sur le pouvoir. Réponses à certaines

critiques », in $D E I I$, texto ${ }^{\circ} 238$, pp. 625-635. (1978)

; «Préface à la transgression (en hommage à Georges

Bataille », in $D E I$, texto ${ }^{\circ}$ 13, pp. 261-278. (1963)

; "Prisons: la chute des murs?", in Vacarme ; Paris, n 29, Automme, 2004.

; «Qu'est-ce que la critique ? (Critique et Aufklärung)», in Bulletin de la Societé Française de Philosophie ; Paris, ano 84, $\mathrm{n}^{\mathbf{0}} 2$, Avril-Juin, 1990.

; «What is Enlightenment? ('Qu' est-ce que les

Lumières ?') », in DE II, texto n 339, pp. 1381-1397. (1984)

; “Qu'est-ce que les Lumières ?", in DE II, texto n' 351, pp.

1498-1507. (1984)

; «Questions à Michel Foucault sur la géographie », in

DE II, texto n ${ }^{\circ} 169$, pp. 28-40. (1976) 
; «Les rapports de pouvoir passent à l'intérieur des corps », in $D E I I$, texto n ${ }^{\circ} 197$, pp. 228-237. (1977)

; « Les reportages d'idées », in DE II, texto n² 250, pp. 706-

708. (1978)

; «Le retour de la morale », in $D E I I$, texto $\mathrm{n}^{\mathrm{o}} 354, \mathrm{pp}$.

1515-1526. (1984)

; «Une révolte à mains nues », in $D E I I$, texto $\mathrm{n}^{\circ} 248$, pp.

701-704. (1978)

; Sécurité, territoire, population-cours au Collège de

France, 1977-1978; Paris, Gallimard-Seuil, 2004.

; "Structuralisme et poststructuralisme", $D E I I$, texto n ${ }^{\circ} 330$, pp. 1250-1276. (1983)

; « Subjetivité et vérité », in DE II, texto n 304, pp. 1032-

1038. (1981)

; "Le sujet et le pouvoir", in DE II, texto no 306, pp. 1041-

1062. (1982)

; «Sur la justice populaire-débat avec les maos », in $D E I$, texto $\mathrm{n}^{\mathrm{o}} 108$, pp. 1208-1237. (1972)

; Surveiller et punir—naissance de la prison ; Paris, Gallimard, 2004.

; "Table ronde du 20 mai 1978", in DE II, texto n' 278, pp.

839-854. (1980)

; «Tehéran : la foi contre le chah », in DE II, texto $\mathrm{n}^{\circ} 244$, pp. 683-688. (1978)

; « Toujours les prisons », in DE II, texto $\mathrm{n}^{\circ} 282$, pp. $915-$

919. (1980) 
; "Va-t-on extrader Klaus Croissant?", in DE II, texto n' 210 , pp. 361-366. (1977)

; A verdade e as formas jurídicas; Rio de Janeiro, Nau

Editora, 2002.

; "Le vie des hommes infames", in DE II, texto n' 198, pp.

237-253. (1977)

; «Vivre autrement le temps », in DE II, texto $\mathrm{n}^{\circ}, 268, \mathrm{pp}$.

788-790. (1979)

LACAN, Jacques ; Meu ensino ; Rio de Janeiro, Jorge Zahar, 2006.

LE GOFF, Jacques; Os intelectuais na Idade Média; Rio de Janeiro, José Olympo, 2003.

LIMA, Tânia Stolze de; "O dois e seu múltiplo: reflexões sobre o perspectivismo em uma cosmologia tupi", in Mana-estudos de antropologia social; São Paulo, vol. 2, n 2, outubro de 1996.

; "O que é um corpo?", in Religião e sociedade; Rio de Janeiro, vol. 22, $\mathrm{n}^{\mathrm{o}}$ 1, 2002.

MACHADO, Roberto ; Ciência e saber - a trajetória da arqueologia de Michel Foucault; Rio de Janeiro, Graal, 1982.

; Foucault, a filosofia e a literatura; Rio de Janeiro, Jorge

Zahar, 2001.

MARTON, Scarlett; "Foucault leitor de Nietzsche", in RIBEIRO, Renato Janine; Recordar Foucault—os textos do colóquio Foucault; São Paulo, Brasiliense, 1986.

MILLER, Jacque-Alain; "Michel Foucault et la psychanalyse", in VÁRIOS ; Michel Foucault philosophe-reencontre international ; Paris, Éditions du Seuil, 1989. 
MORAES, Eliane Robert ; O corpo impossível - a decomposição da figura humana de Lautréamont a Bataille; São Paulo, FAPESP/Iluminuras, 2002.

OVERING, Joanna; “A estética da produção: o senso de comunidade entre os cubeo e os piaroa", in Revista de Antropologia; São Paulo, vol. 34, 1991.

PLATÃO; Alcibiade (e outros); Paris, Gallimard, 1998.

POTTE-BONNEVILLE, Mathieu; Michel Foucault, l'inquiétude de l'histoire ; Paris, PUF, 2004.

RACHJMAN, John; Eros e verdade-Lacan, Foucault e a questão da ética; Rio de Janeiro, Jorge Zahar, 1994.

RIBEIRO, Renato Janine; "O discurso diferente", in Ribeiro, Renato Janine; $A$ última razão dos reis; São Paulo, Companhia das Letras, 2002.

; "O intelectual e seu outro", in Tempo Social; São Paulo, v. 7, n. 1-2, 1995.

; "A ideologia é algo tão relativo", in Cult; São Paulo, n 89, fevereiro/2005, ano VII.

; "O poder das palavras: Hobbes sobre a liberdade", in NOVAES, Adauto (coord.); O avesso da liberdade; São Paulo, Companhia das Letras, 2002.

ROY, Olivier ; « Charges expõe geopolítica da indignação », in Folha de São Paulo, 9 de fevereiro de 2006, p. A 13. no 29. ; "L'énigme du soulevement", in Vacarme; Paris, Automme 2004,

SKINNER, Quentin; Liberdade antes do liberalismo; São Paulo, Unesp, 1999.

TEMPO SOCIAL; São Paulo, v. 7, n. 1-2, outubro 1995. 
VEYNE, Paul; «Foucault revolutionne l'histoire », in VEYNE, Paul ; Comment on écrit l'histoire ; Paris, Seuil, 2002, pp. 383-429.

VILAÇA, Aparecida; "Fazendo corpos: reflexões sobre morte e canibalismo entre os wari' à luz do perspectivismo", in Revista de Antropologia; São Paulo, vol. 41, $\mathrm{n}^{\mathrm{o}} 1,1998$.

VIVEIROS DE CASTRO, Eduardo; "Perspectivismo e multinaturalismo na América Indígena", in VIVEIROS DE CASTRO, Eduardo; A inconstância da alma selvagem; São Paulo, Cosac\&Naify, 2002.

ZIZEK, Slavoj ; « Introdução—o espectro da ideologia », in ZIZEK, Slavoj (coord.) ; Um mapa da ideologia; Rio de Janeiro, Contraponto, 1999. 